UC $-34 \mathrm{C}$

Issued: May 1988

DE88 010184

Background Radiation from

Fission Pulses

T. R. England

E. D. Arthur

M. C. Brady*

R. J. LaBaune

* Collaborator at Los Alamos. Nuclear Engineering Applications Department.

Onk Ridge National lahoratory. Oak Ridge, TN 37831. 


\section{CONTENTS}

ABSTRACT.

I. INTRODUCTION

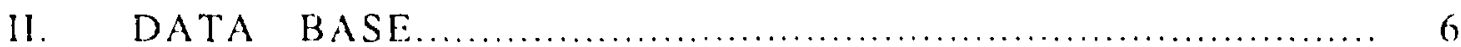

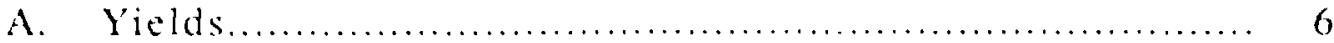

B. Halflives and Decaly Branching.................................... 7

C. Beta/Gamma Spectra and Their Decay Energies......................... 7

D. Pn Values and Delayed Neutron Spectrat ................................ 7

III. DELAYED NEUTRONS: CLRRENT DATA EVALUATION ............... 10

Precursor Data................................................... 10

IV. CALCULATED $\nabla_{\mathrm{d}}$ SPECTRA FROM FISSION PULSES …............... 30

V. DELAYED $\beta$ - AND $\gamma$ RADIATION FROM FISSION PRODUCTS .......... 44

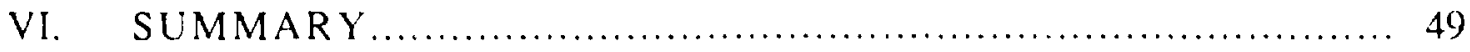

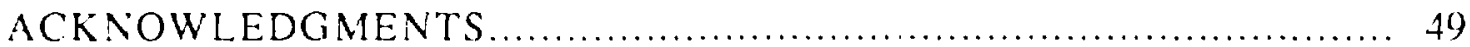

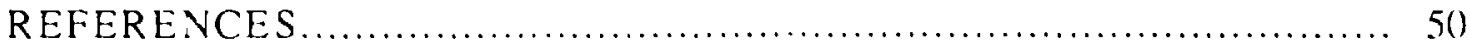

APPENDIX A. GENERAL BIBLIOGRAPHY FOR DELAYED NEUTRONS...... 53

APPENDIX B. INDIVIDUAL PRECURSOR CONTRIBUTIONS ….............. 65 


\section{FIGURES}

1. Delayed neutrons from fission........................................... 2

2. Some explicit fission-product chains...................................... 2

3. Schematic of yield distrihution.............................................. 3

4a. Location of fission-product and delayed neutron precursors................... 3

4h. Locition of fission-product and delayed neutron precursors................... 4

$5 . \quad$ Schematic of decay plus delayed neutron emission ............................ 5

6. Delayed neutron spectra for nuclide 94gRb................................ 19

7. Spectra as a fraction > E for nuclide 94gRb ................................. 19

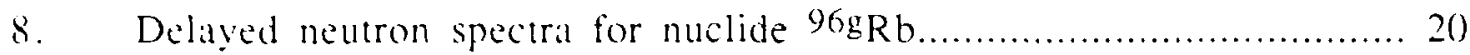

9. Spectra as a fraction $>\mathrm{E}$ for nuclide $96 \mathrm{~g} \mathrm{Rb}$.................................. 20

10. Delayed neutron spectra for nuclide 92gRb .................................. 21

11. Spectra as a fraction $>$ E for nuclide 92gRb................................. 21

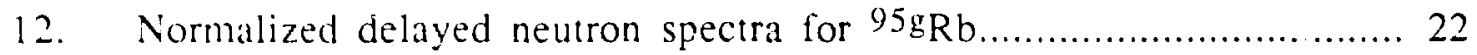

13. Normalized delayed neutron spectra for ${ }^{94} \mathrm{Rb}$............................... 24

14. Normalized delayed neutron spectra for ${ }^{96} \mathrm{Rb}$................................. 24

15. Normalized delayed neutron spectra for ${ }^{143} \mathrm{Cs}$.............................. 25

16. Normalized delayed neutron spectra for ${ }^{134} \mathrm{Sn}$............................... 25

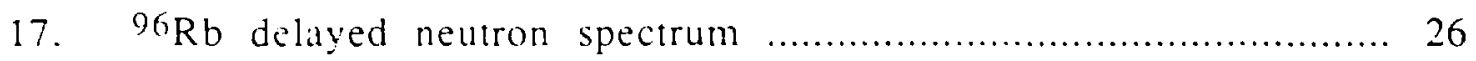

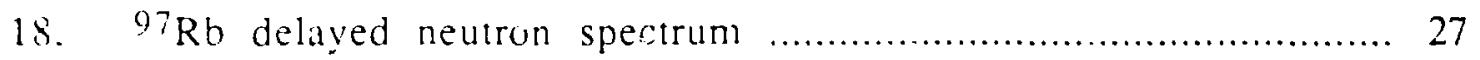

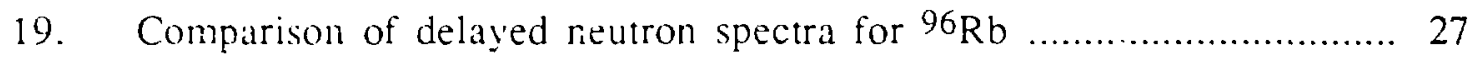

20. Neutron spectrum, $1-5 \mathrm{~s}$ after Godiva burst .................................. 28

21. Neutron spectrum, 5-10 s after Godiva burst................................ 29

22. Neutron spectrum, 10-20 s after Godiva burst ............................ 29

23. Total $v_{d} / s$ for eight fuels $v s$ time (pulse) .................................... 32

24. $\quad 235 \mathrm{U} v_{d}$ spectra comparisons at 5 s....................................... 32

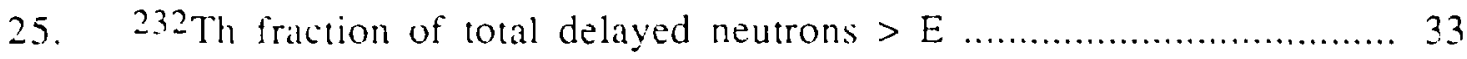

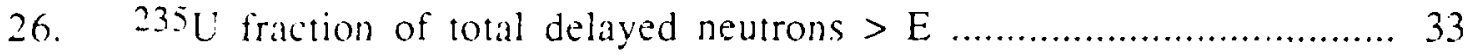

27. $238 \mathrm{~L}$ fraction of total delayed neutrons $>\mathrm{E}$..................................... 34

28. ${ }^{239} \mathrm{Pu}$ fraction of total delayed neutrons $>\mathrm{E}$................................. 34

29. Comparison of spectra fractions at $1 s$....................................... 35

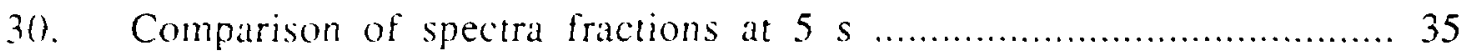

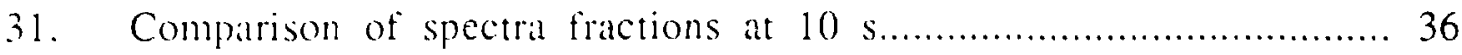

32. Comparison: fraction of neutrons $>\mathrm{E}$ above $4 \mathrm{MeV}$ at $1 \mathrm{~s} \ldots \ldots \ldots \ldots \ldots \ldots . . . . . . . .36$

3. Comparison: fraction of neutrons $>\mathrm{E}$ above $4 \mathrm{MeV}$ at $5 \mathrm{~s} \ldots \ldots \ldots \ldots \ldots \ldots \ldots . . \ldots 37$ 
34. $\quad y_{d}$ spectrat comparisons at 1 s

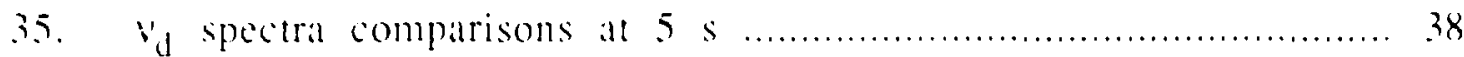

36. $v_{4}$ spectria comparisons at 10 s...................................... 38

37. Absolute delityed neutron spectra per fission for $\mathrm{E}>4 \mathrm{MeV}$................. 39

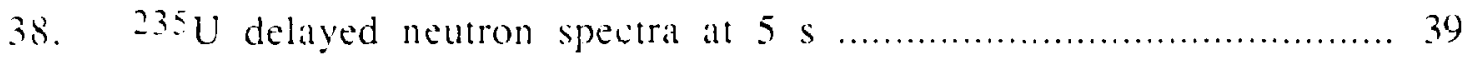

39. Number of precursors having energies $>\mathrm{E}$.................................. 43

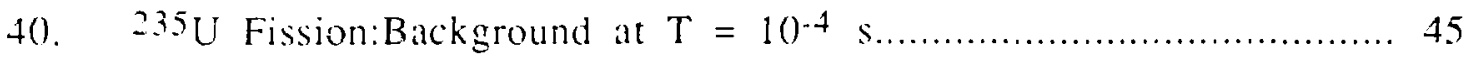

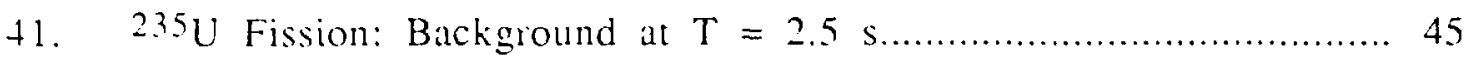

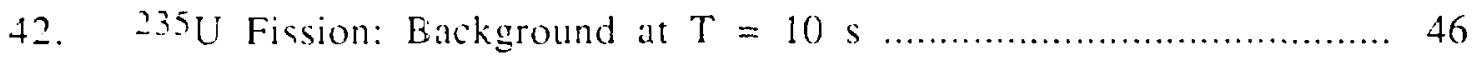

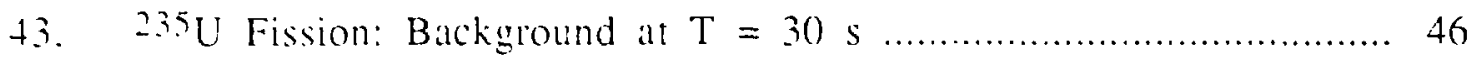

44. Betal decily heat for $238 \mathrm{U}$ (Pulse),......................................... 47

45. Gamma decay heat for $238 \mathrm{U}$ (Pulse)..................................... 47

46. Gaimma decay heat for 232Th (Pulse)................................. 48

47. Beta decily heat for 232 Th (Pulse)........................................ 48 
I. Summary of Experimental Spectra............................................

II. Content of Current Data Base ................................................... 9

III. Precursor Enission Probabilities (Pn), Sources of Data, and Types of

Spectra Modifications................................................. 11-17

IV. Delayed Neutron Yield Rate per 100 Fissions at $t=10^{-4} \mathrm{~s} \ldots \ldots \ldots \ldots \ldots \ldots \ldots . . . \ldots 1$

V. Total Delayed Neutron Rate vs Cooling Time .............................. 40

VI. $\quad 235 \mathrm{U}$ - Fraction of Delayed Neutrons Above Energies in 1/2-MeV Increments.. 41

VII. $\quad 238 \mathrm{U}$ - Fraction of Delayed Neutrons Above Energies in 1/2-MeV Increments.. 41

VIII. $\quad 232 \mathrm{Th}$ - Fraction of Delayed Neutrons Above Energies in 1/2-MeV Increments. 42

IX. $\quad{ }^{239} \mathrm{Pu}$ - Fraction of Delayed Neutrons Above Energies in $1 / 2-\mathrm{MeV}$ increments. 42

\section{TABLES (APPENDIX B)}

B-I. Precursors Having Probable Delayed Neutron Energies Above Noted Values.. 66-69

B-II. $\quad 235$ U Fission Pulse - Per Cent Contribution per Precursor Greater than $0.01 \%$

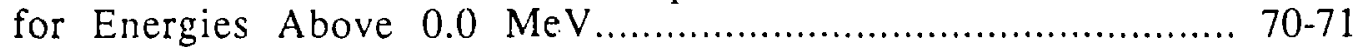

B-III. 235U Fission Pulse - Per Cent Contribution per Precursor Greather than $0.01 \%$

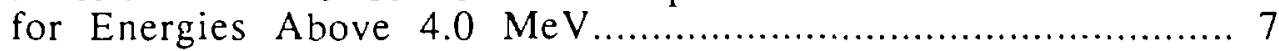

B-IV. 238U Fission Pulse - Per Cent Contribution per Precursor Greater than $0.01 \%$ for Energies Above $0.0 \mathrm{MeV}$.....

B-V. $\quad 238$ U Fission Pulse - Per Cent Contribution per Precursor Greater than $0.01 \%$ for Energies Above 4.0 MeV

B-VI. ${ }^{239} \mathrm{Pu}$ Fission Pulse - Per Cent Contribution per Precursor Greater than $0.01 \%$

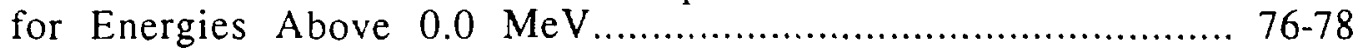

B-VII. ${ }^{239}$ Pu Fission Pulse - Per Cent Contribution per Precursor Greater than $0.01 \%$ for Energies Above 4.0 MeV............................................... 78

B-VIII. ${ }^{232}$ Th Fission Pulse - Per Cent Contribution per Precursor Greater than $0.01 \%$ for Energies Above $0.0 \mathrm{MeV}$

B-IX. $\quad{ }^{232}$ Th Fission Pulse - Per Cent Contribution per Precursor Greater than $0.01 \%$ for Energies Above 4.0 MeV 


\title{
BACKGROUND RADIATION FROM FISSION PULSES
}

by

T. R. England, E. D. Arthur, M. C. Brady, and R. J. LaBauve

\begin{abstract}
Extensive source terms for beta, gamma, and neutrons following fission pulses are presented in various tabular and graphical forms. Neutron results from a wide range of fissioning nuclides (42) are examined and detailed information is provided for four fuels: ${ }^{235} \mathrm{U}$, ${ }^{238} \mathrm{U},{ }^{232} \mathrm{Th}$, and ${ }^{239} \mathrm{Pu}$; these bracket the range of the delayed spectra. Results at several cooling (decay) times are presented. For $\beta^{-}$and $\gamma$ spectra, only $235 \mathrm{U}$ and ${ }^{239} \mathrm{Pu}$ results are given; fissionproduct data are currently inadequate for other fuels. The data base consists of all known measured data for individual fission products extensively supplemented with nuclear model results. The process is evolutionary, and therefore, the current base is summarized in sufficient detail for users to judge its quality. Comparisons with recent delayed neutron experiments and total $\beta-$ and $\gamma$ decay energies are included.
\end{abstract}

\section{INTRODUCTION}

Two, and occasionally more, neutron rich nuclides remain following a neutron induced fission, as illustrated in Fig. 1. These fission products can be any one of approximately 1300 species, and they are all present in varying amounts following a sufficiently large number of fissions. Most nuclides are radioactive and coupled by their decay, as shown in Fig. 2 for 20 of the 1300 products. The initial amount of each product following a fission pulse is described by a probability per fission, or fission product yield, that varies with the fissioning species and with the initial neutron fission energy. Figure 3 is a simplified illustration of the distribution of the initially yielded products where $\mathrm{Zp}$ is the most probable product per mass chain. Figures $4 \mathrm{a}$ and $4 \mathrm{~b}$ show the location of $\mathrm{Zp}$ and delayed neutron precursors for $235 \mathrm{U}$ fast fission. 


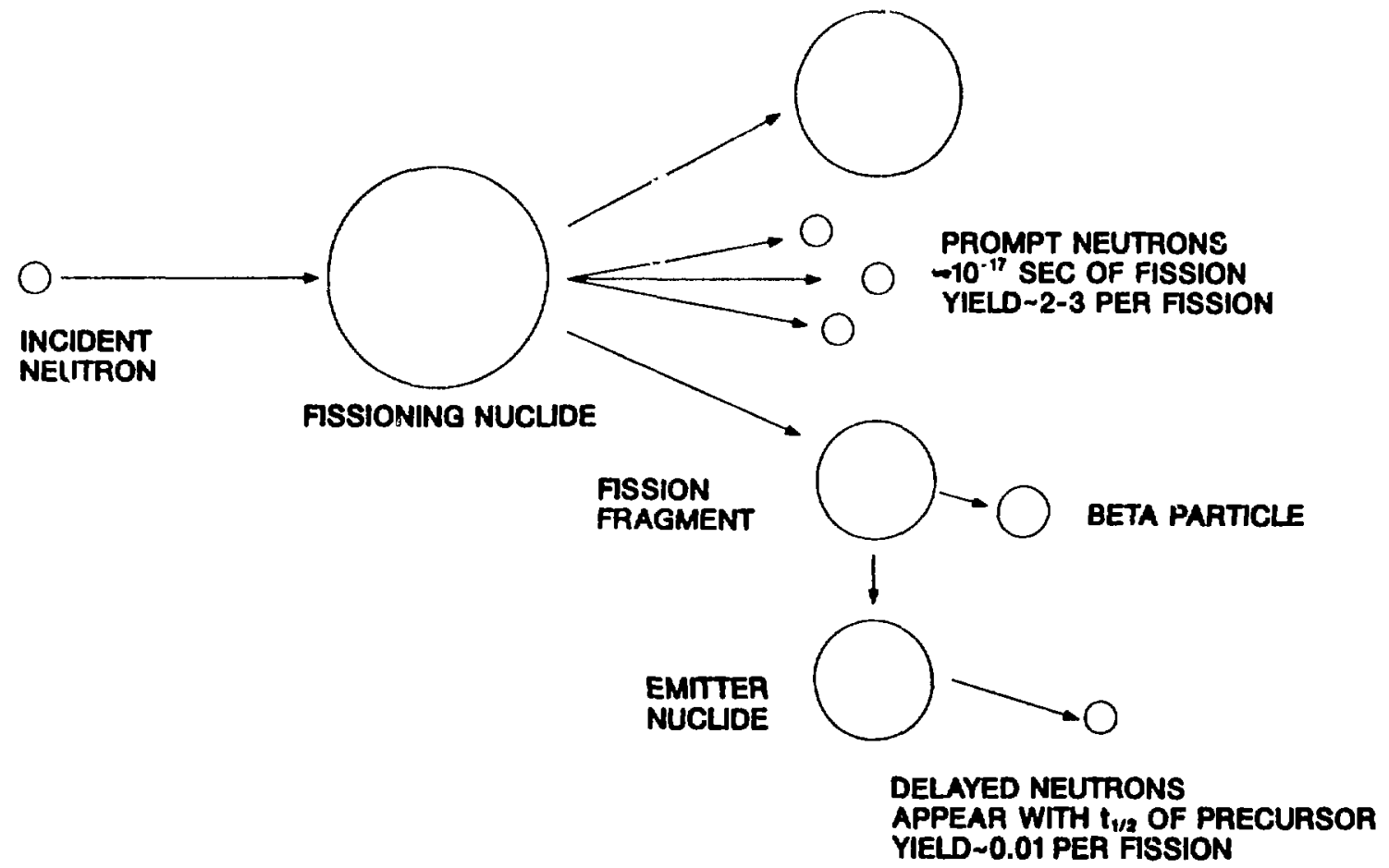

Fig. 1. Delayed neutrons from fission.

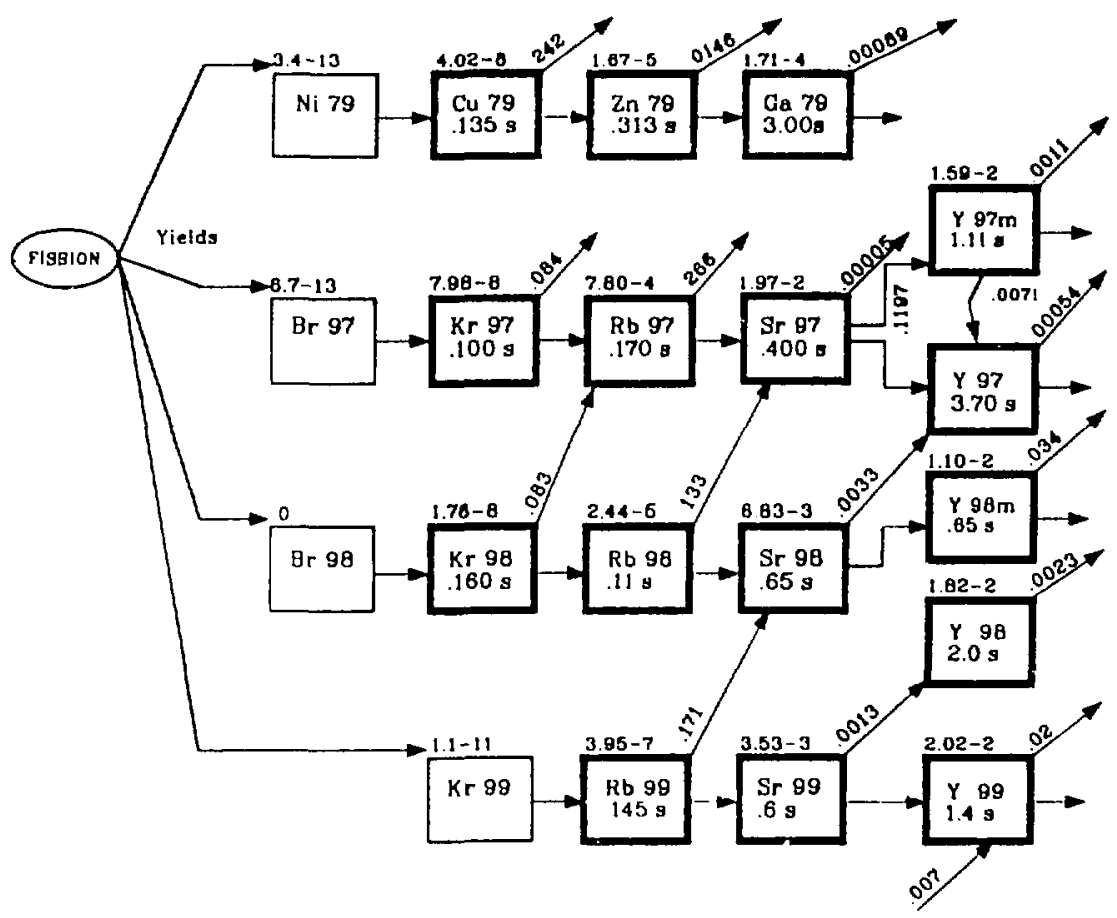

Fig. 2. Some explicit fission-product chains. 


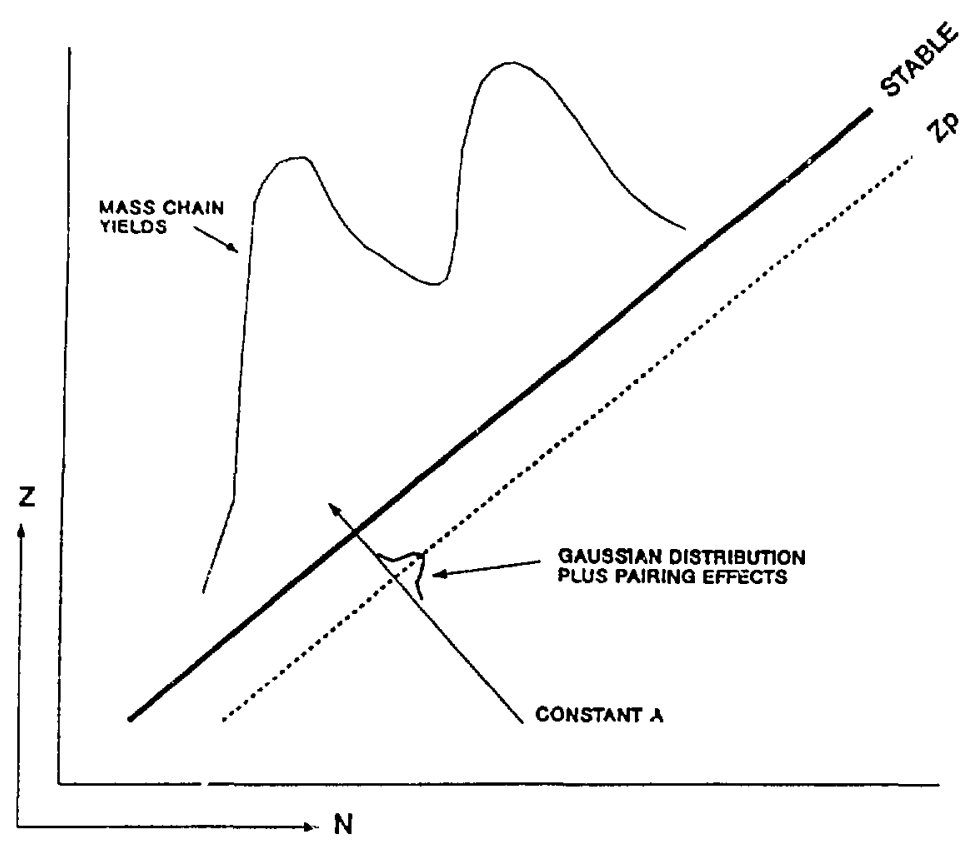

Fig. 3. Schematic of yield distribution.

LARGEST FISSION YIELD

Last stable nuclide in $\vec{Z}$-chain

Indicates isomeric state

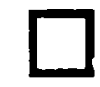

$>10 \%$

$\square 1-10 \%$

$\square \quad 0.1-1 \%$

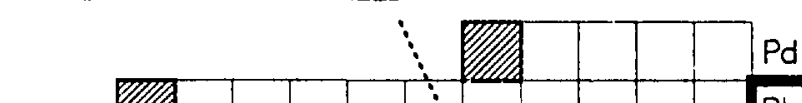




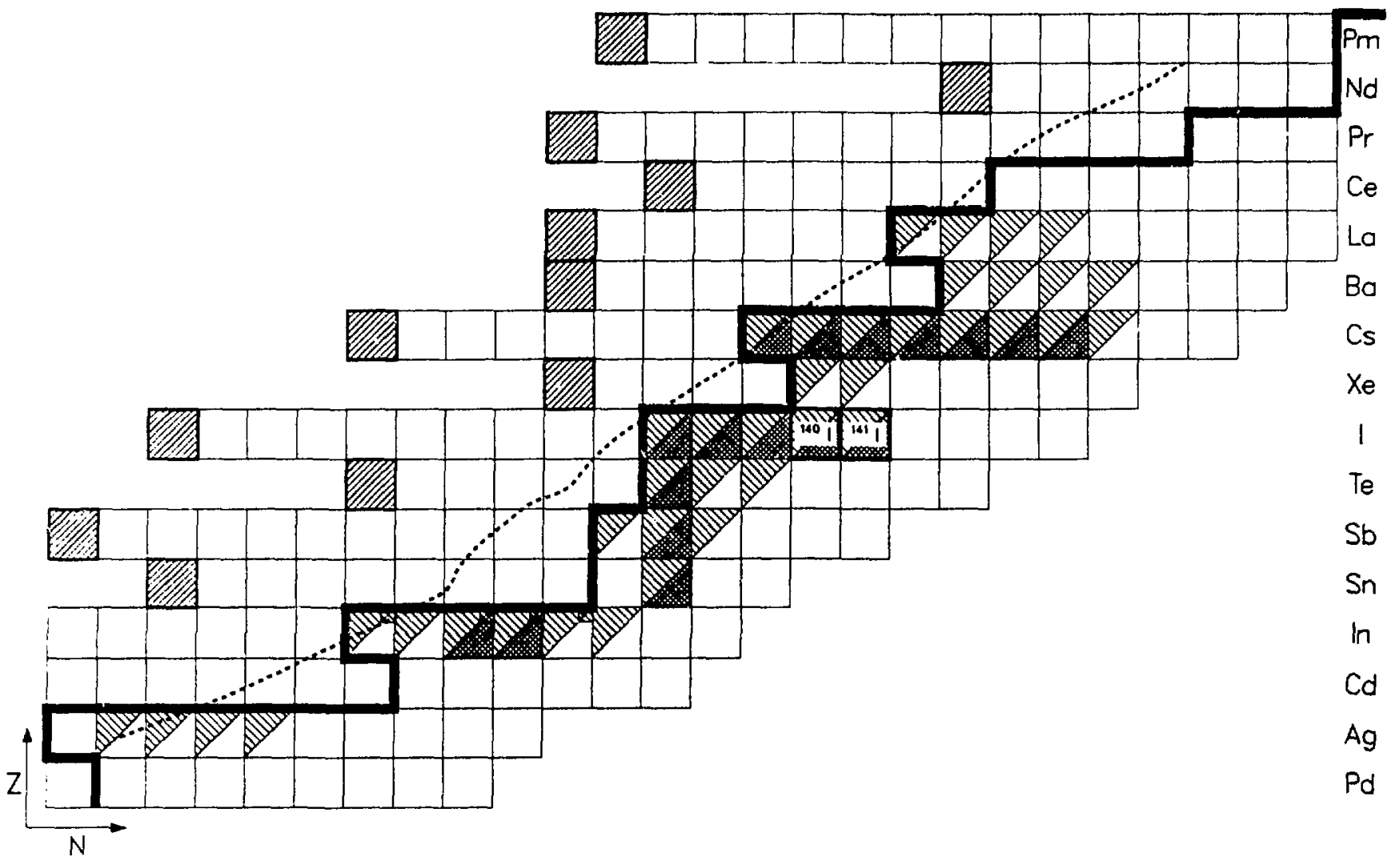

Fig. 4b. Location of fission product and delayed neutron precursors.

The total population of this plexus of products remains a constant in time equal to approximately twice the number of fissions in the pulse. However, the amount of each product changes continuously because of decay couplings, as do radiations associated with decay. Most of the decays are initiated by $\beta$ - transitions to excited states of the daughter product and are immediately followed by cascading gammas to lower energy states. In some cases $(\sim 150)$, the lower energy states are long-lived and can decay by either $\beta$ - or an additional cascade of gammas to the ground state. In approximately 270 of the initial products, some of the $\beta$ - transitions leave the daughter product in an excited state exceeding the binding energy, $S(n)$, of a neutron and hence each such decay probably results in the emission of neutrons. In a very few cases $(<10)$, the parent nuclide of the neutron rich products decays by the emission of an alpha particle; however, the usual decays and radiations are illustrated in Fig. 5. Each of the $\beta$-transition energies is actually a mixture of energies (in some continuous probability) of an electron and anti-neutrino and not a discrete value for either particle. 


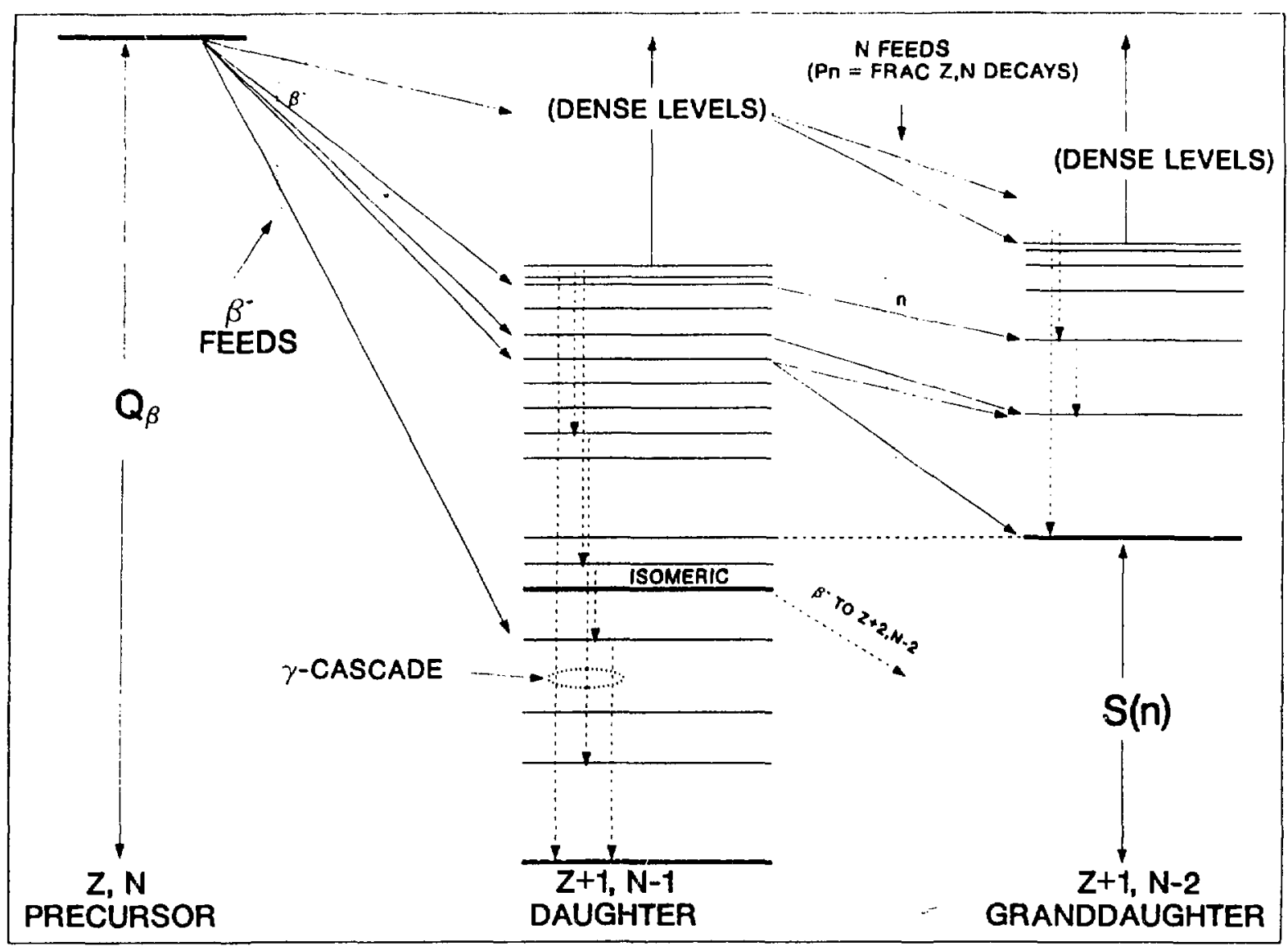

Fig. 5. Schematic of decay plus delayed neutron emission.

If we knew the fission-product yield, decay halflife, probability of each type of decay or branching fraction, and associated energy spectrum for each type of radiation, it would be possible to describe the time-dependent behavior and radiation field of the fission-product debris. We now have codes, notably, a version of CINDER ${ }^{1}$ and associated codes based on it, capable of calculating the time-dependence of each nuclide and each type of radiation for any mixture of fissioning nuclides. Basically, we first calculate the time-dependent quantity of each product and its activity and then fold in the various spectral types and sun these into an aggregate spectrum. The process is exact and the accuracy is limited by the uncertainties of the input data, some of this being based on measurements and some on nuclear models.

In this report, we describe the input source data of the nuclides available through fiscal year 1987 and present aggregate, time-dependent results of the total ensemble for the principal 
radiations $(\beta, \gamma$, and $n)$. These form the dominant background radiations for any observer or instrument. The neutrons constitute a major portion of the discussion in this report.

The information in this report is intended as source data for further studies. For example, any detector will see additional temporal changes due to expanding debris, depending on its location. Here, all results describe isotropic radiation from a point source. The relative importance of the spatial expansion of the debris is dependent on each detector's location and is not considered nere. The detectors are assumed to be shielded against the initial prompt neutron, $x$-ray, and gamma pulse sources. These can be calculated for any particular device, but they are not being included in this discussion. Here, the source terms apply to the continuously changing interference environment or background remaining following the fission pulse.

The background is device-dependent because of the mixture of fissioning nuclides and number of fissions. Except where noted, we have assumed that each pulse contains $1.3 \times 10^{26}$ fissions, or approximately the equivalent of $1 M T$, if all energy is from the fission of a sirigle fissioning species.

The reader should be aware that measurements and improvements in nuclear models are currently in progress and results from these could significantly alter data for particular fission products. While changes in the aggregate total radiations are less likely to be significant, values at the large radiation energies could certainly change. The information in this report can be considered as the most extensive estimates of the radiation background to date and should serve as a reference or fiducial report for further studies.

\section{DATA BASE}

Calculations require fission-product yields, nuclide halflives, decay branching fractions to isomeric and ground states of the daughter products and branching by those neutrons following beta decay (i.e., "delayed neutrons" or $\nabla_{d}$ ) and the beta, gamma, and neutron energy spectra for each nuclide. Except for spectra, all parameters are used to form chains of nuclides coupled, as in Fig. 2. (For fission pulses, we do not require neutron cross sections, but for extended irradiations, cross sections are required and these, like the delayed neutrons, cross couple the mass chains.)

\section{A. Yields}

The fission-product yields in use are a preliminary, unpublished version for ENDF/B-V1, 2 described in Ref. 3; mass chain yields are listed in Ref. 3 as well. All yield data are being updated and reevaluated prior to issue in Version VI of ENDF/B; the data in use are the most recent available and are current to about mid-1983. For this study, we did alter the $238 \mathrm{U}$ fast-fission yields primarily in their distribution along the mass chains. The method of evaluation and the 
distribution models are described in Ref. 3. (Only the $238 \mathrm{U}$ proton pairing parameter was changed from values listed in that reference. The change was based on recent unpublished measurements made at Grenoble, France, and it resulted in a significant alteration in the calculation of delayed neutrons; however, it is less importanî to other aggregate quantities.)

Most high-energy neutron yields are based on nuclear models and systematics, not on measurements.

\section{B. Halflives and Decay Branching}

Except for neutron branching (denoted as $\mathrm{Pn}$ ), these data are taken from ENDF/B-V 2 and are listed in the summary document of Ref. 4. As noted in a later section, we now have sufficient tests to believe in their validity and the yield data can be assessed as generally very good.

\section{Beta/Gamma Spectra and Their Decay Energies}

Earlier testing of these ENDF/B-V data ${ }^{2}$ demonstrated that measured nuclide spectra were usually deficient for many high-Q transitions. 5,6 An earlier version of ENLF/B that relied more on nuclear model generated spectra showed better agreement with benchmark experiments than Version V. Other countries have also discovered the deficiency and the only reasonable recourse in the near future for individual nuclides is an augmentation of spectra using nuclear models. ${ }^{7}$ As discussed later, this has already been accomplished for total $\beta$ - and $\gamma$ decay energies, but not spectra, by the Japanese, 8,9 with excellent results. As related to this report, the total $\beta^{-}$and $\gamma$ energies recommended by the Japanese are used in place of those in ENDF/B-V. Iere, however, our primary interest is in aggregate spectra. For this purpose, we use 18- and 19-group functions fitted to our calculated spectra 6 after some adjustment based on the measured spectra of Dickens 10,11 reduced to a fission pulse. These functions also compare very well with measurements of total decay energies but apply only to ${ }^{235} \mathrm{U}$ and ${ }^{239} \mathrm{Pu}$ fission. We have no measured spectra for ${ }^{238} \mathrm{U}$ to use for similar fits. In any case, we need improved spectra for individual products if we are to use our developed capability for general spectra calculations for any fissioning nuclide.

\section{Pn Values and Delayed Neutron Spectra}

These data were simply inadequate in any known evaluation/compilation. A very incomplete set of Pn values (delayed neutron branching fractions), but no individual spectra, exist in the ENDF/B files. Therefore, a large part of our effort to date on the nuclear background has been toward compiling, evaluating, and generating a complete set of delayed neutron data. The method of evaluating measured Pn's is described in Ref. 12. These data have now been revised through 1985 and appear in Section III. Measured Pn's now exist for 85 nuclides, but there are $>270$ 
nuclides having $Q_{\beta}$ values exceeding the neutron binding energy $S(n)$ based on nuclide masses. All are assumed to be delayed neutron precursors. This assumption is very reasonable; to date, all nuclides having the sufficient energetics (illustrated in Fig. 5) have been found to be neutron precursors.

Thirty-four of the precursors have one or more known spectral measurements. However, we have found no measured spectra prior to the beginning of this study that extend above $3 \mathrm{MeV}$, although many precursors have sufficient energetics for higher energy delayed neutrons. In these cases, it is necessary to augment the measurements with nuclear model calculations and to use models for the 237 unmeasured spectra, as was done in Ref. 13 for 76 spectra. Some model spectra can be important because of their large energy emission, but some are included simply for completeness, being relatively unimportant as a result of small $P n$ and/or yield values.

All measured spectra are normalized; also, prior to normalization, experimental data were generally missing at both low and high energy values. With the exception of 4 , all of the 34 measured spectra had to be augmented with model values. Thus, 241 of the 271 precursor spectra include some model values and 237 are based totally on models.

Table I summarizes the experimental spectra source and Table $I$, the general content of the data base. This extensive base is a dominant part of this report and will be further described in Section III. Reference 14 also provides a summary of the effort through September 1986; also a disserta $a$ : $n$ preparation by a co-author of this report, ${ }^{15}$ will provide detail relevant to each change mave to $3: e$ in measured spectra. (The dissertation is primarily concerned with aggregate steady-state specura $<3 \mathrm{MeV}$ imporiant to reactors. Spcctra at larger energies for some individual precursors will be discussed in the dissertation only because of the need to extend spectra to obtain a proper normalization. For this purpose, it will contain some information from Refs. 14 and 16).

The extensive Los Alamos data base for delayed neutrons is summarized in more detail in the following section. It results from national and international cooperation with periodic research over the past ten years and from an intensive effort over the past three years.

A general bibliography for delayed neutrons is attached as Appendix A of this report. 
TABLE I

\section{SUMMARY OF EXPERIMENTAL SPECTRA}

Studsvik measurements:

${ }^{3} \mathrm{He}$ spectrometers

On-line isutope separator

Measurements for $\sim 25$ precursor nuclides

Energy range $\sim 100 \mathrm{keV}-2 \mathrm{MeV}$

Mainz measurements:

${ }^{3} \mathrm{He}$ spectrometers

On-line isotope separator

Measurements for $\sim 23$ precursor nuclides

Energy range $\sim 40 \mathrm{keV}-3 \mathrm{MeV}$

INEL measurements:

Proton-recoil spectrometer

On-line isotope separator (TRISTAN-ISOL)

Measurements for 8 precursor nuclides

Energy range $\sim 10 \mathrm{keV}-1300 \mathrm{keV}$

TABLE II

CONTENT OF CURRENT DATA BASE

$\rightarrow 271$ PRECURSORS (BASED ON ENERGETICS)

o $\quad$ Pn - DN Emission Probabilities

- 85 Evaluated measurements

o 186 From systematics (fit to Kratz-Hermann equation)

- Spectra (10 keV Bins)

- $\quad 34$ Measured (30 augmented with Beta Code)

- 237 From model calculations (Modified Evaporation Model)

- FP Yields, $\mathrm{t}_{1,2}, \beta^{-}$, and $\gamma$ Branchings

o Yields from a preliminary ENDF/B-VI version

o Branchings from ENDF/B-V 


\section{DELAYED NEUTRONS: CURRENT DATA EVALUATION}

As noted in Section II(D), of the 271 probable delayed precursors, only 34 have measured spectra and 85 have measured emission probabilities (Pn values). Such number comparisons can be misleading. As stated in Ref. 13, we found that 29 precursors having spectral measurements account for $70-82 \%$ of the total delayed neutron emission rate at equilibrium. For fission pulses, the 34 measured precursors account for $75-99 \%$ of the total rate at various cooling times. (The percentage increases monotonically with cooling time.) Furthermore, most measured spectra do not cover the complete energy range and some unmeasured short-lived precursors are likely to produce a large fraction of the neutrons at high energies. In addition, complete Pn data are needed in fission-product yield evaluations.

\section{Precursor Data}

Table III lists Pn values for 271 nuclides and provides details on the bases of data for these and each spectra in the current data files. The table is important because it is a succinct record of the augmentations made in measured spectral data and in the origin of major data sources used in the systematic and nuclear models. For example, under the column labelled "Spectra Source," the notation for ${ }^{95} \mathrm{Rb}$ is $(\mathrm{m}) \mathrm{GO} .2 \mathrm{M} 1.8 \mathrm{~B}$. The " $(\mathrm{m})$ " denotes that the spectra are based primarily on measurements; but, for reasons to be described, the spectral shape below $0.2 \mathrm{MeV}$ comes from INEL measurements by Greenwood and Caffrey, ${ }^{17}$ and, above $1.8 \mathrm{MeV}$ [up to $\mathrm{Q}_{\beta}-\mathrm{S}(\mathrm{n})=4.952$ $\mathrm{MeV}$, the shape is based on the BETA code model. ${ }^{18}$ The dominant part of the emitied neutrons come, in this case, from measurements at the University of Mainz and are supplied by $\mathrm{K}$. - $\mathrm{L}$. Kratz, ${ }^{19}$ and other cases use data supplied by G. Rudstam. ${ }^{20}$ The $4.952-\mathrm{MeV}$ energy window is based on mass tables referenced under columns M1, M2, and M3, where MN refers to MïllerNix, ${ }^{21}$ and W81 refers to a preliminary unpublished version of the W83 Wapstra and Audi 1983 mass table (published in 1985). ${ }^{22} \mathrm{Q}_{\beta}$ depends on the parent and daughter masses [sources under $M 1$ and $M 2$, and $S(n)$ on the daughter and granddaughter masses (sources under M2 and M3)]. Values listed under "Norm Area" define the range used to renormalize the low- and high-energy spectra to the experimental data.

Only the notations under "Spectra Source" require such a detailed explanation. In general, the G, M, and R, respectively, refer to the INEL, Mainz, and Studsvik measurements, B to the BETA code, and EVAP to an evaporation model to be described. Only 4 of the 34 measured spectra have no modification. [These have "MAINZ" or "RUDSTAM" indicated following the "(m)"]. The reasons for modification are discussed later in this section. 
TABLE III

PRECURSOR EMISSION PROBABILITIES (Pn), SOURCES OF DATA, AND TYPES OF SPECTRA MODIFICATIONS ${ }^{a}$

\begin{tabular}{|c|c|c|c|c|c|c|c|c|c|c|c|}
\hline CS & ID & $\mathrm{HL}$ & $P_{n}$ & $d P n$ & GP & $\begin{array}{c}\text { Pn } \\
\text { Source }\end{array}$ & $\begin{array}{l}\text { Spectra } \\
\text { Source }\end{array}$ & $\mathrm{Q}_{\beta}$ & $s(n)$ & $\begin{array}{c}\text { Mass } \\
\text { Tables } \\
\text { M1 M2 M3 }\end{array}$ & $\begin{array}{l}\text { Norm } \\
\text { Area }\end{array}$ \\
\hline
\end{tabular}

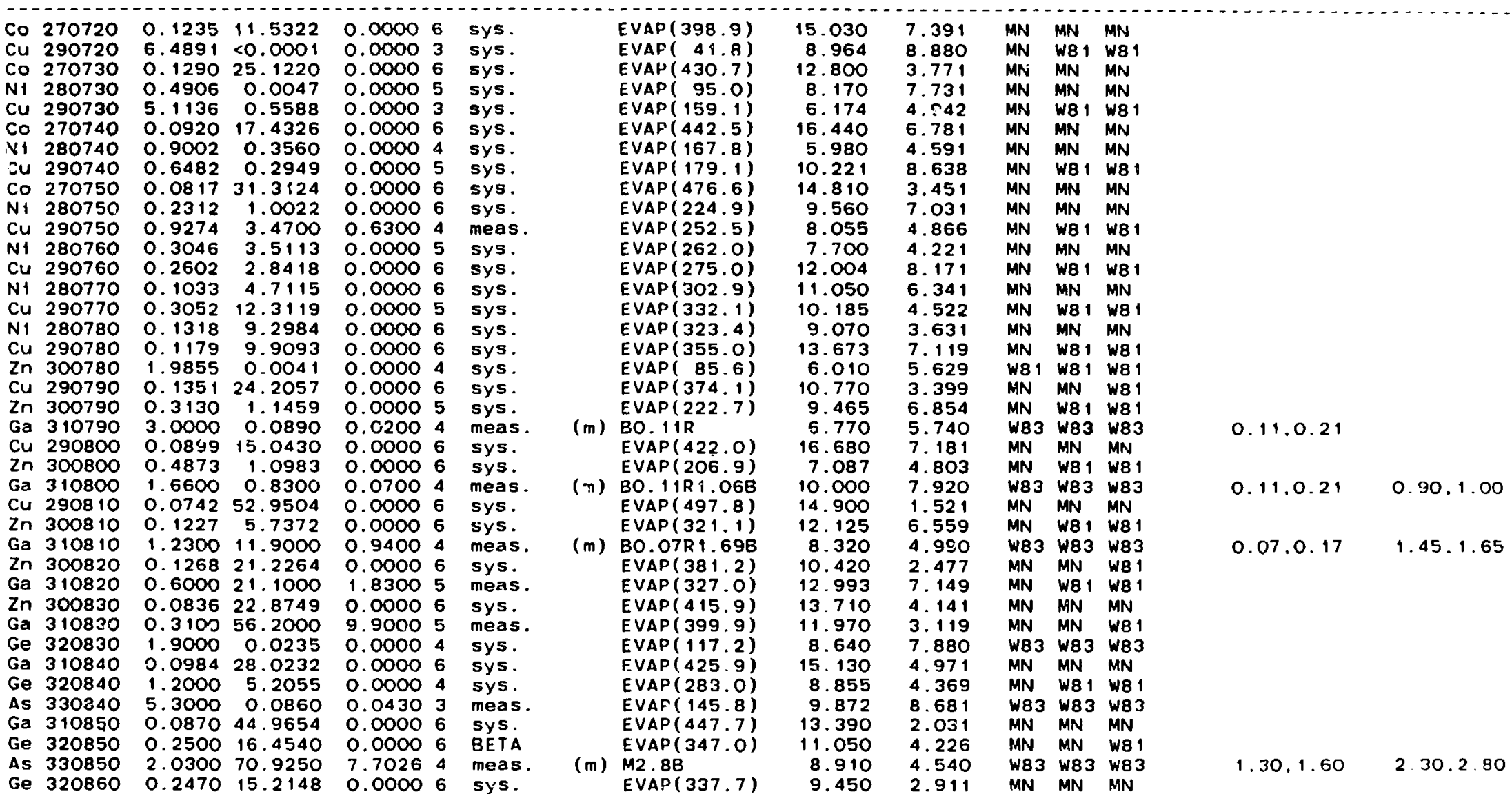

(Cont 1 nued)

aSee page 17 (end of table) for General Notes. 
Table III (Cont.)

\begin{tabular}{|c|c|c|c|c|c|c|c|c|c|c|c|}
\hline $\mathrm{cs}$ & ID & HL & Pn & $d P n$ & $\begin{array}{c}\text { Pn } \\
\text { GP Source }\end{array}$ & $\begin{array}{l}\text { Spectra } \\
\text { Source }\end{array}$ & $\mathrm{Q}_{\beta}$ & $s(n)$ & $\begin{array}{c}\text { Mass } \\
\text { Tables } \\
\text { M1 M2 M3 }\end{array}$ & $\begin{array}{c}\text { Norm } \\
\text { Area } \\
1\end{array}$ & $\begin{array}{c}\text { Norm } \\
\text { Area } \\
2\end{array}$ \\
\hline
\end{tabular}

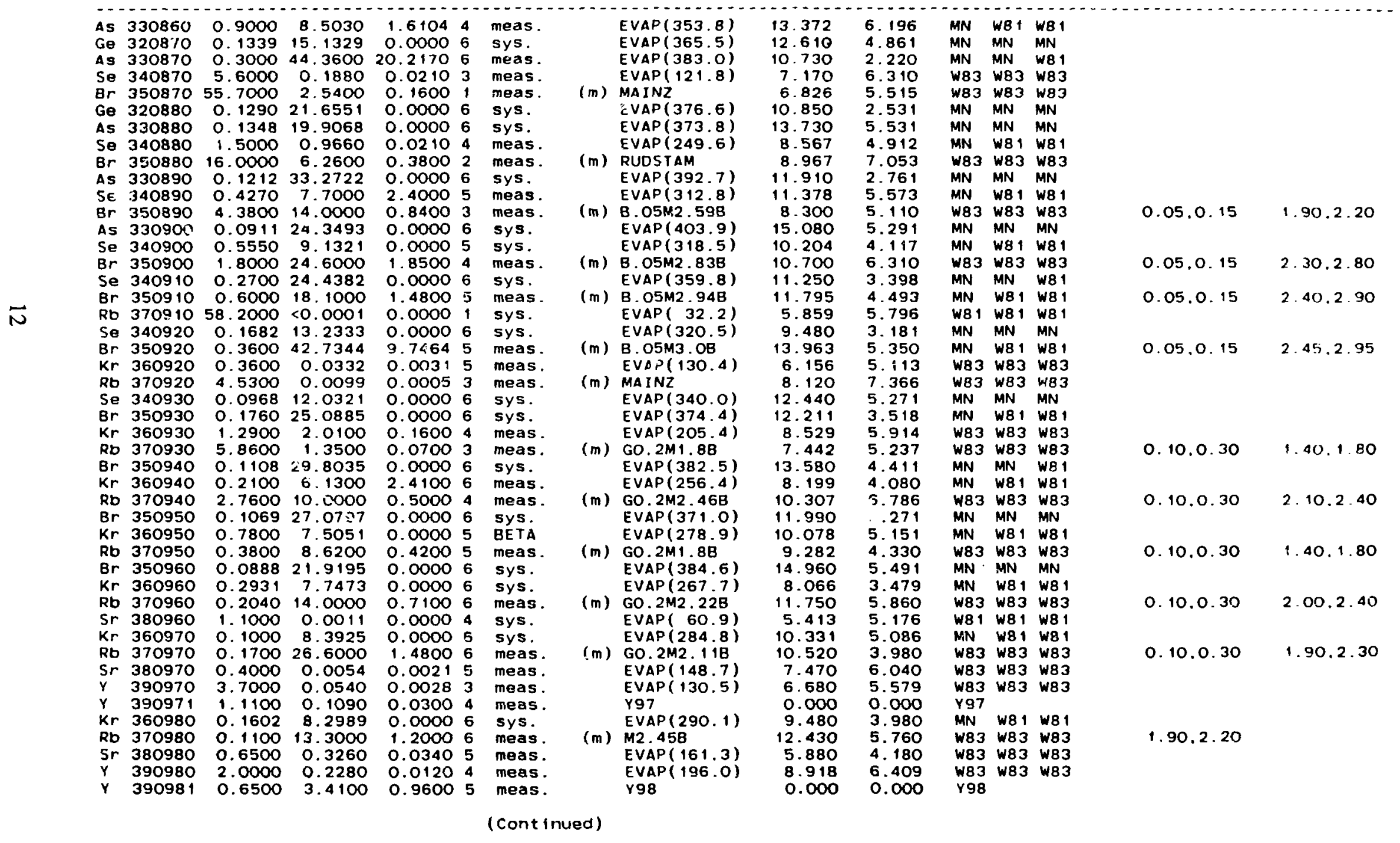




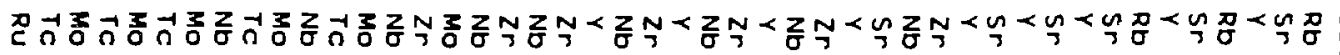

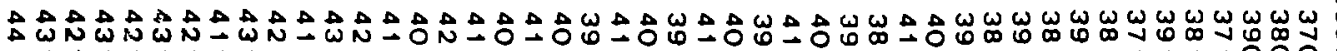

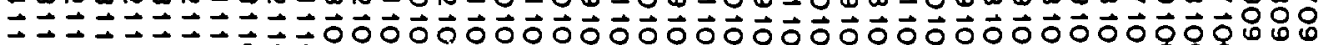

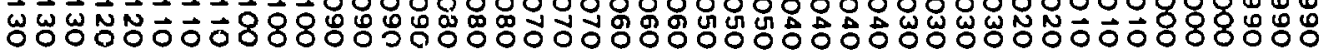
WOOOO-OOONO--OO-OOOOO-OONOOANOO--OOOOOOOOOOO-OO రํํำ

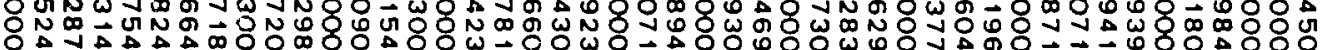

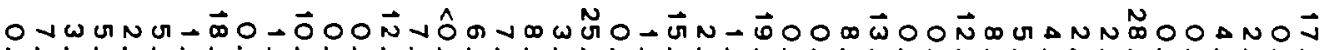

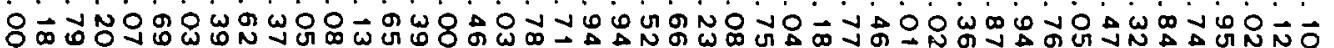

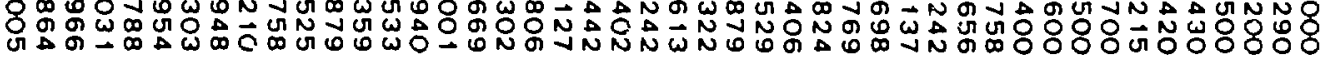
$00000000000000000000000000000000000-n 00000--00$

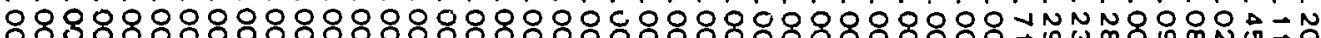

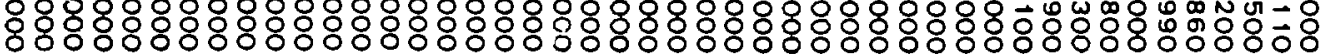
$\triangle$ лा

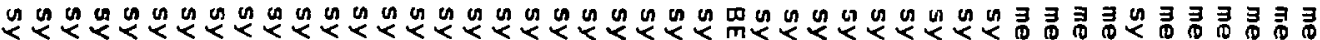
की

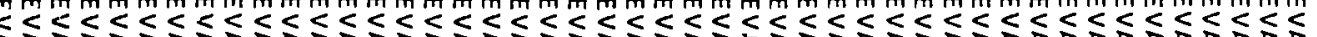

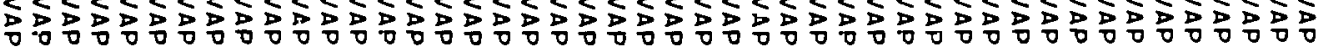

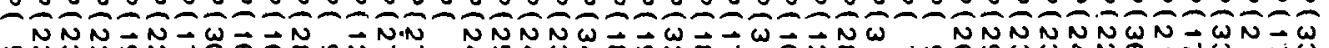

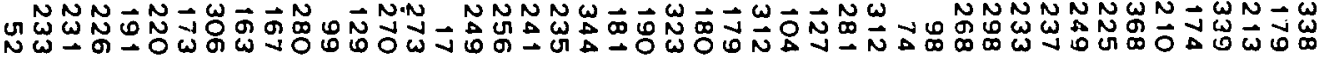
.

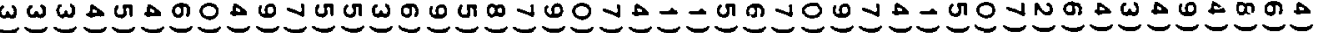

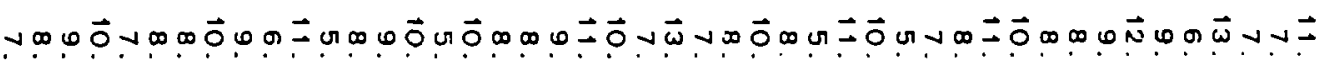

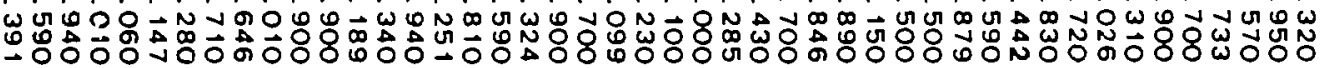

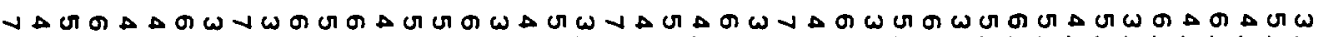

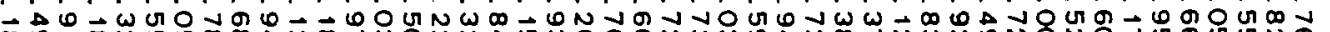

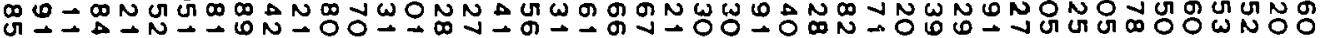

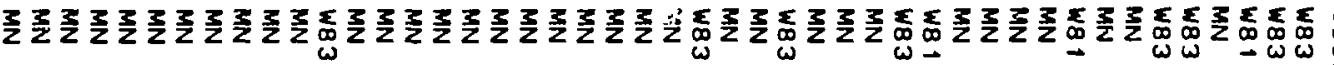

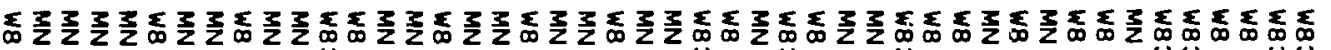

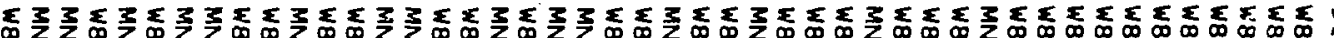




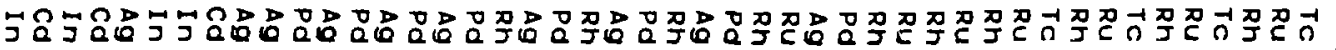

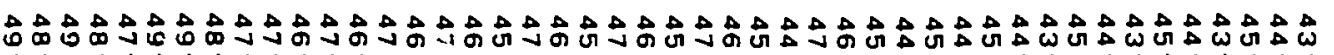

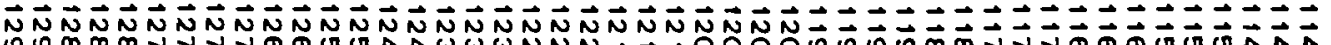

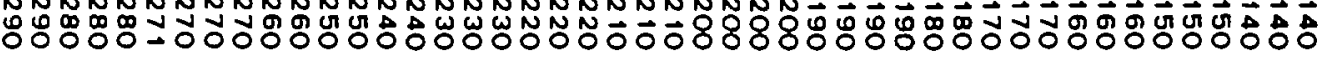

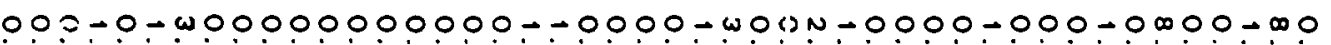

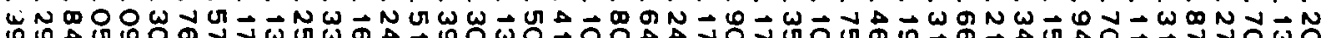
แ

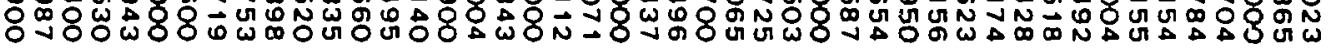

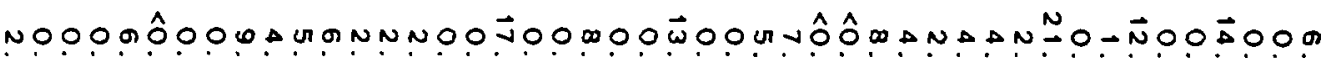

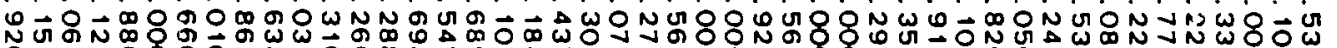

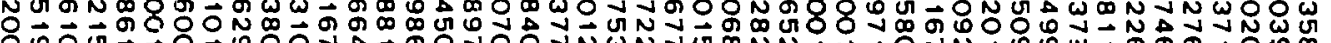
0000000000000000000000000000000000000000000000

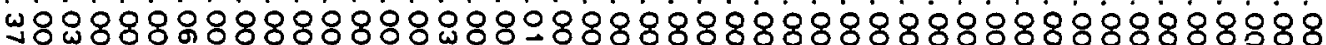

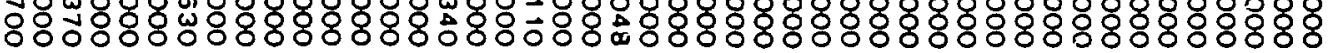

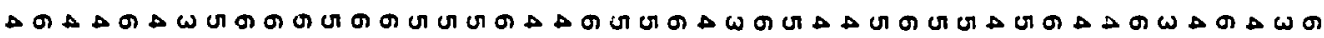

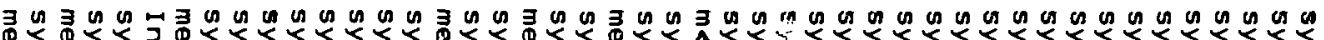

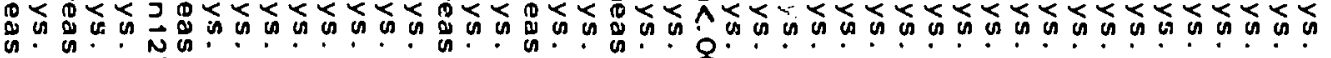

$$
\widehat{\mathbf{3}}
$$

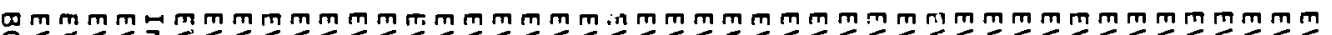

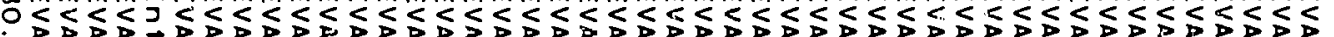

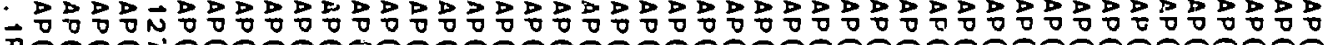

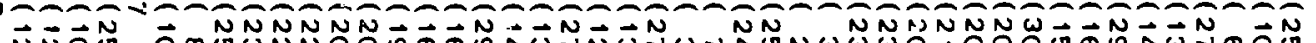

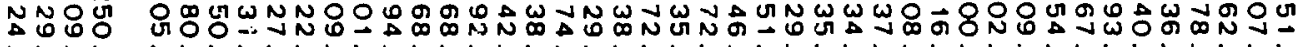

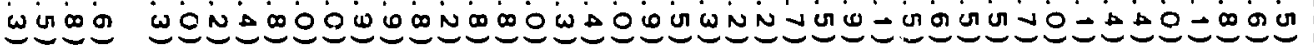
VCOG

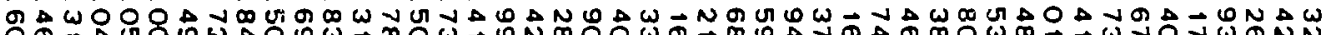

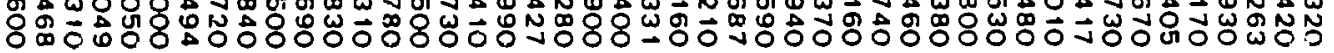

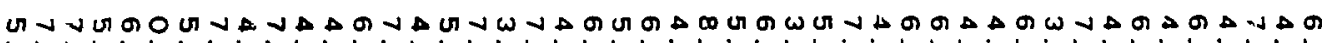
w

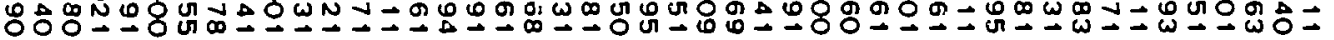

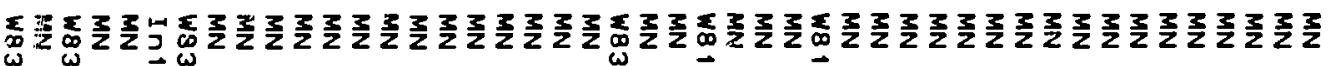

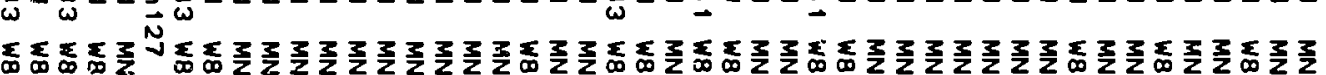

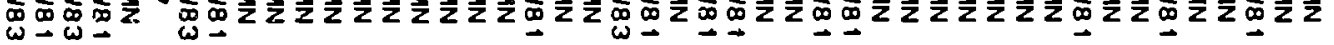

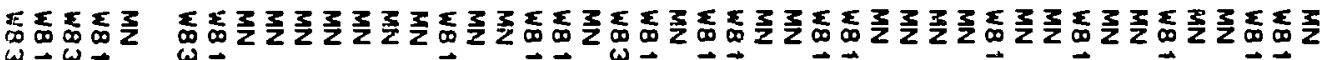

$$
\begin{aligned}
& \text { i } \\
& \text { a } \\
& \text { I } \\
& \text { J } \\
& \text { 욱 } \\
& \text { จ } \\
& \text { o } \\
& \text { כ } \\
& \text { ถ } \\
& \begin{array}{ll}
n & 0 \\
0 & 0 \\
5 & 0 \\
0 & 0 \\
0 & 0 \\
0
\end{array} \\
& \text { 吕 } \\
& \infty \\
& \text { บ } \\
& \text { I }
\end{aligned}
$$

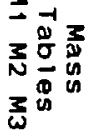


Table III (Cont.)

Pn dPn GP Source

Spectra

$Q_{\beta} \quad s(n)$

Mass
Tables

M1 M2 M3

Norm

Are

Norm

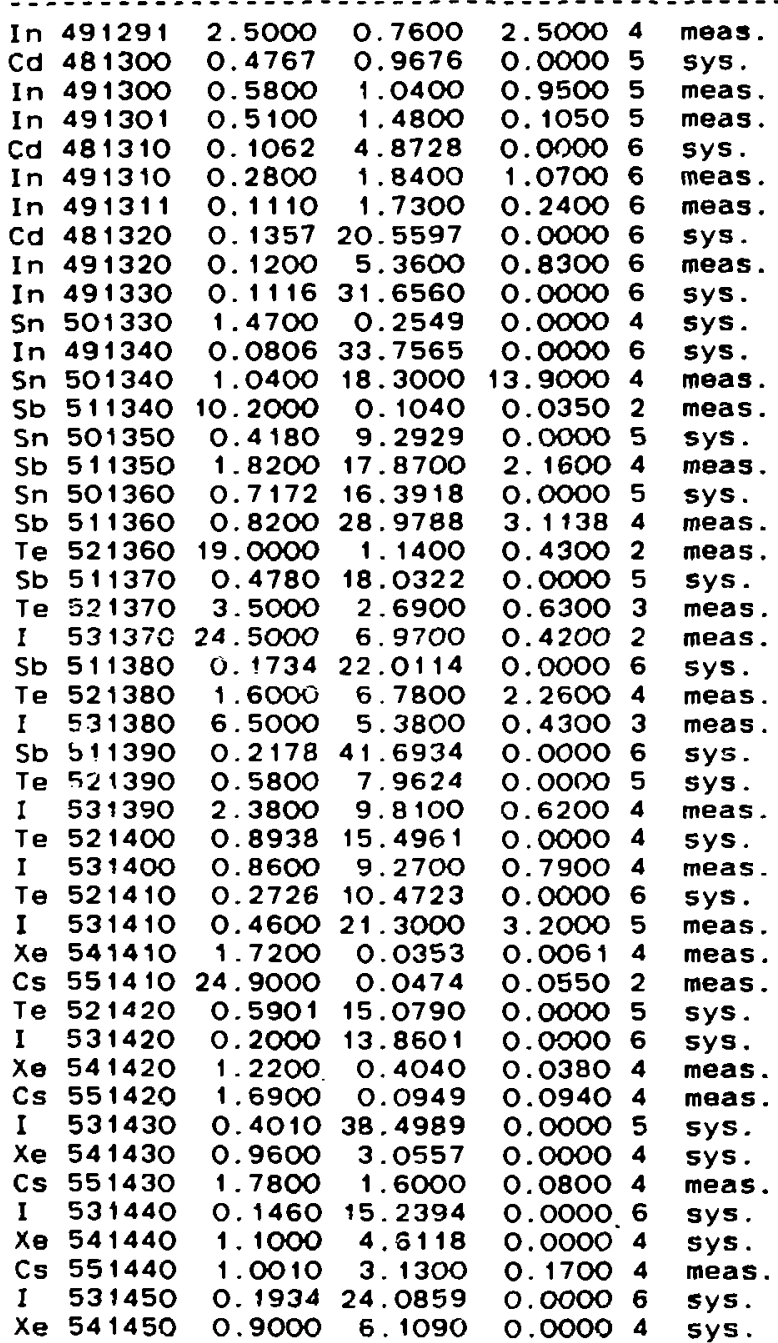

In 129

In129

(m) BO. $12 R$

In 130

In 130

$\operatorname{EVAP}(249.4)$

In 131

EVAP (318.5)

EVAP ( 259.5)

EVAP ( 332.8$)$

EVAP (137.2)

EVAP (349.3)

0.000

0.000

0.000

In 129

10.200

0.000

12.068

8.820

0.000

11.820

13.235

12.600

9.050

(m) BO. 1R1.62B

14. 740 EVAP (100.9) 8.910

EVAP (237.4) $\quad 9.580$

(m) M2.075B

EVAP ( 254.4$)$

9.580
7.540

8. 300

9.611

m) BO.07R

EVAP ( 250.9$)$

5. 100

9.020

7. 020

5.885

EVAP (280 5$)$

EVAP $(165.5)$

11.610

6.432

(m) R1.92B

EVAP (292.3)

7.820
9.640

9.640
9.321

9.321
6.820

२1.61B

EVAP (234.2)

7.360

9.967

VAP (243.2)

(m) R1.68B

EVAP ( 82.8 )

10.050

8.892

6.155

5.256

EVAP (246.4)

8. 330

EVAP ( 97.2$)$

11.553

5. 040

7.320

8.900

EVAP (272.5)

8. 510

m) GO. $2 \mathrm{M} 1.1 \mathrm{~B}$ EVAP $(256.4) \quad, 11.280$ EVAP (192.0)

11. 280

7.236
8.460

8.460

9.930
9.191

5.029

IN129

0.000 in 130

6.635 MN WB1 WB1

5.250

0.000

2.893
7.308

2.777

7.380

3.841

3.091

7.500
4.507

3. 510

2.431

4. 642

3.760

3.270

5.070

4.025

4.371

3.913

5.820

1.721
4.610

3.640

2.240

5.392

4. 491

3. 417

5.510

4.548

2.581

5. 242

4.146

6.210

1.819

5.289

4. 240

4.971

3.697

5.870

GO. $2 M 1.1758$

EVAP $(269.1)$

.93

W83 W83 W83

In 131

MN MN W81

MN W81 W81

MN MN WB1

W83 WB3 W83

MN MN MN

MN MN

WR 1 W81

W83 W83 W83

MN MN WBI

W83 W83 :183

MN MN MN

MN W81 W81

W83 W83 W83

MN MN WBI

W83 W83 W83

W83 W83 WB3

MN MN MN

MN MN MN

W83 W83 W83

MN MN MN

MN WE1 WBI

W83 W83 W83

MN MN WB1

MN WBI W81

MN MN MN

MN W81 W81

W83 W83 W83

MN MB1 WB1

W83 W83 W83

WB3 W83 W83

MN MN W81

MN W81 W81

W83 W83 W83

MN MN INN

WB3 W83 WB3

W83 W83 W83

MN W81 W81
$0.12,0.22$

0.10 .0 .20

1.40 .1 .60

.575 .2 .075

0.07 .0 .17

1.20 .1 .50

1.35 .1 .75

$1.42,1.92$

$1.30,1.60$

0.09 .0 .19

1.40 .1 .70

1.00 .1 .60

0.63 .0 .93

0.10 .0 .30

0.80 .1 .10

0.10 .0 .30

0.875 .1 .175

(cont 1 nued) 
Table III (Cont.)

\begin{tabular}{|c|c|c|c|c|c|c|c|c|c|}
\hline ID & HL & $P n$ & $d P n$ & $\begin{array}{c}P n \\
\text { GP source }\end{array}$ & $\begin{array}{l}\text { Specira } \\
\text { Source }\end{array}$ & $\mathrm{Q}_{\beta}$ & $S\left(r_{1}\right)$ & $\begin{array}{c}\text { Mass } \\
\text { Tables } \\
\text { M1 M2 M3 }\end{array}$ & $\begin{array}{l}\text { Norm } \\
\text { Area } \\
1\end{array}$ \\
\hline
\end{tabular}

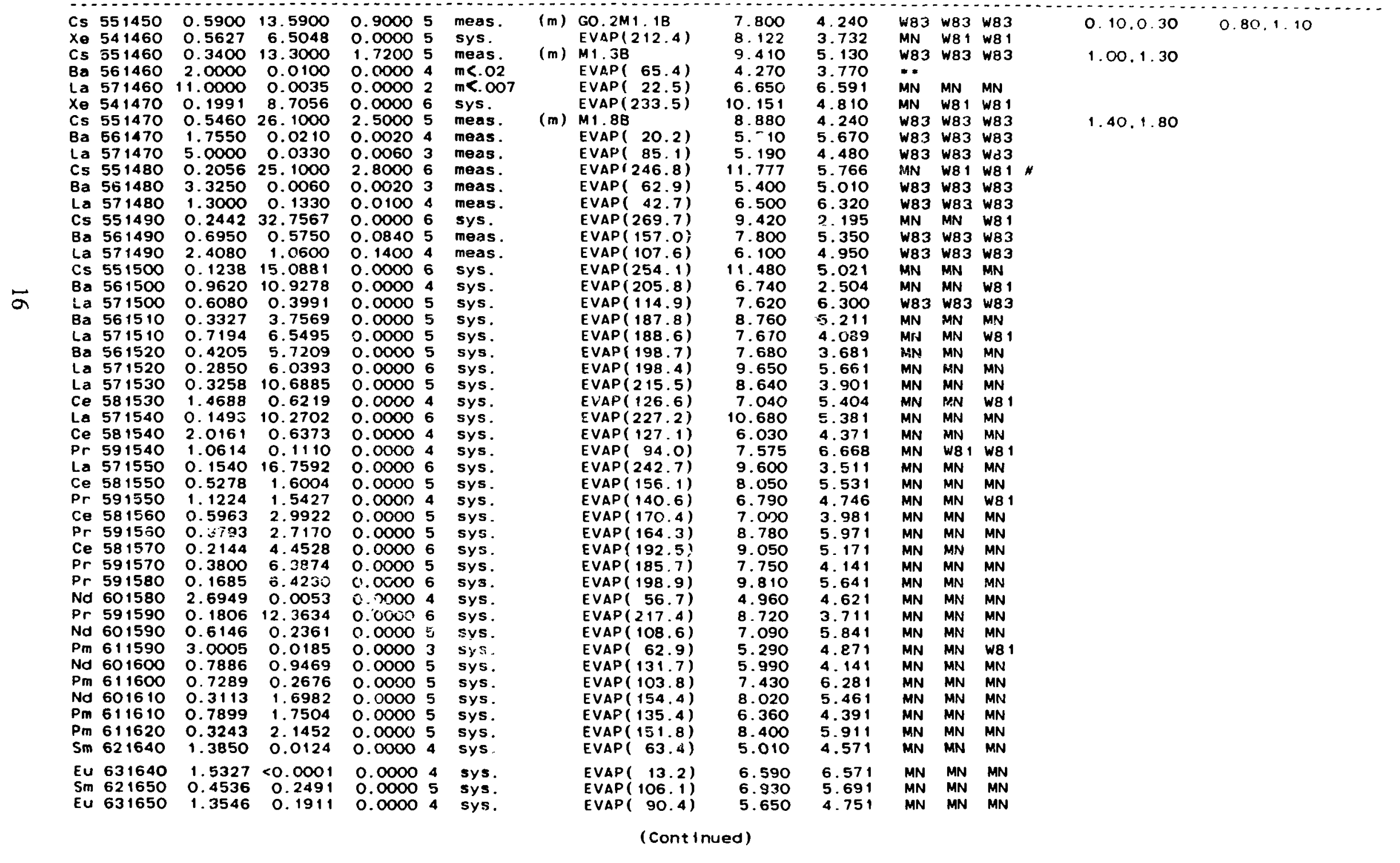




\section{aGencral Notes}

This table contains the latest evaluated Pn values (10/86). Values indicated as derived from systematics are based on a least squares fit of the evaluated Pn values to the parameters in the Herrmann-Kratz equation. (The current spectral file is labeled tp3final.)

CS - chemical symbol

ID - nuclide ID $=10000 * \mathrm{Z}+10 * \mathrm{~A}+\mathrm{S}$

HL - halflife in seconds (For most nuclides, these values are taken from the ENDF/B-V summary, Ref. 4.)

Pn - probability of delayed neutron emission in per cent

$\mathrm{dPn}$ - uncertainty in Pn value ( 0.0 for calculated values)

GP - indicates which of the six temporal groups the nuclide probably belongs in.

$Q_{\beta}$ and $S(n)$ are in $\mathrm{MeV}$.

Norm Area 1 and Norm Area 2 give the energy bounds in MeV being used in normalizing the spectra that were joined at the energies indicated under spectra source where energies are also in $\mathrm{MeV}$ and

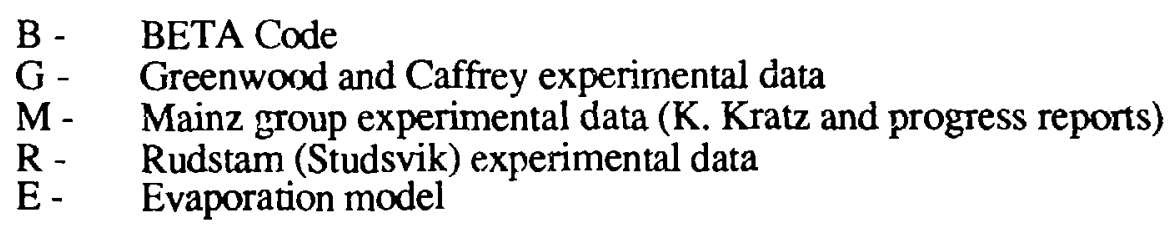

M1 - source of mass of Z, A

M2 - source of mass of $Z+1, A$

M3 - source of mass of $\mathrm{Z}+1, \mathrm{~A}-1$

MN - Möller-Nix (Ref. 21)

W81 - Wapstra81 (Intermediate version of Ref. 22)

W83 - Wapstra83 (Ref. 22)

If the spectrum source is "EVAP," the temperature parameter in keV is given in parentheses.

** A fictitious $S(n)$ is given this nuclide to obtain a positive energy window. Möller-Nix masses give a negative energy window. However, this precursor has a measured Pn value.

\# $\quad$ Most evaporation spectra were calculated using W81 or MN masses; some nuclides do have Wapstra83 masses available. W83 masses agree with those used to calculate this evaporation spectra (in terms of energy difference) with the exception of those indicated by \#. [For \#Cs-148, the W81 values give an energy window $=0.411 \mathrm{MeV}$ larger than the $\mathrm{W} 83$ masses $\left(Q_{\beta}\right)=10.92$, $\mathrm{S}(\mathrm{n})=5.6, \mathrm{Pn}=6.9075)$.

The systematic Pn values are from the Kratz-Hermann equation using Fred Mann's fit for $a$ and $b$ from the Birmingham meeting, September 1986 |a $=54.0, \mathrm{~b}=3.44$. 
Pn values and uncertainties are listed in per cent. Eighty-five are based on an updated evaluation (through 1986), including recent, unpublished data by Reeder and Warner. ${ }^{23}$ The evaluation uses the methodology we described in Ref. 12; the updating is described in Ref. 24 (to be published). The $85 \mathrm{Pn}$ values have the notation "meas." under the column Pn Source. The rest use the $Q_{\beta}$ and $S(n)$ values in the systematic equation of Hermann and Kratz: 25

$$
\left.P n=a\left[Q_{\beta}-S(n)\right) /\left(Q_{\beta}-K\right)\right]^{b}
$$

where $b(=3.44)$ and $a(=54.0)$ are fitted to the evaluated Pn's and

$$
\begin{aligned}
\mathbf{K} & =0 & & \text { even-even precursor } \\
& =13 / A^{1 / 2} & & \text { odd precursor } \\
& =26 / A^{1 / 2} & & \text { odd-odd precursor. }
\end{aligned}
$$

Exceptions to these general statements are either evident or explicity noted in the table.

Somie of the problems found with measured spectra and with model approximations are illustrated in Figs. 6-12. The data for the nuclides 94 gRb (Figs. 6 and 7), 96gRb (Figs. 8 and 9), and ${ }^{92 \mathrm{gRb}}$ (Figs. 10 and 11) are plotted in two forms: the three different nuclide spectra are conventional histogram plots, followed by the same information plotted after its cenversion to the fractional number of neutrons above the abscissa energy. The fractional plots emphasize differences at high energies, and are therefore more useful in comparison with some measurements now in progress. The range of the abscissa for these six plots is identical to the energy window, $Q_{\beta}-S(n)$, derived from mass tables. The general shape of the experimental spectrum in Fig. 6 is typical; clearly, in measurements over the total energy range, the higher range of pcssible neutron inergies would be very uncertain due to the relatively low counting rate. Model calculations extend over the full energy range, and in this case, follow the general shape of the measured spectra; these models cannot, however, reproduce the actual fine structure. 


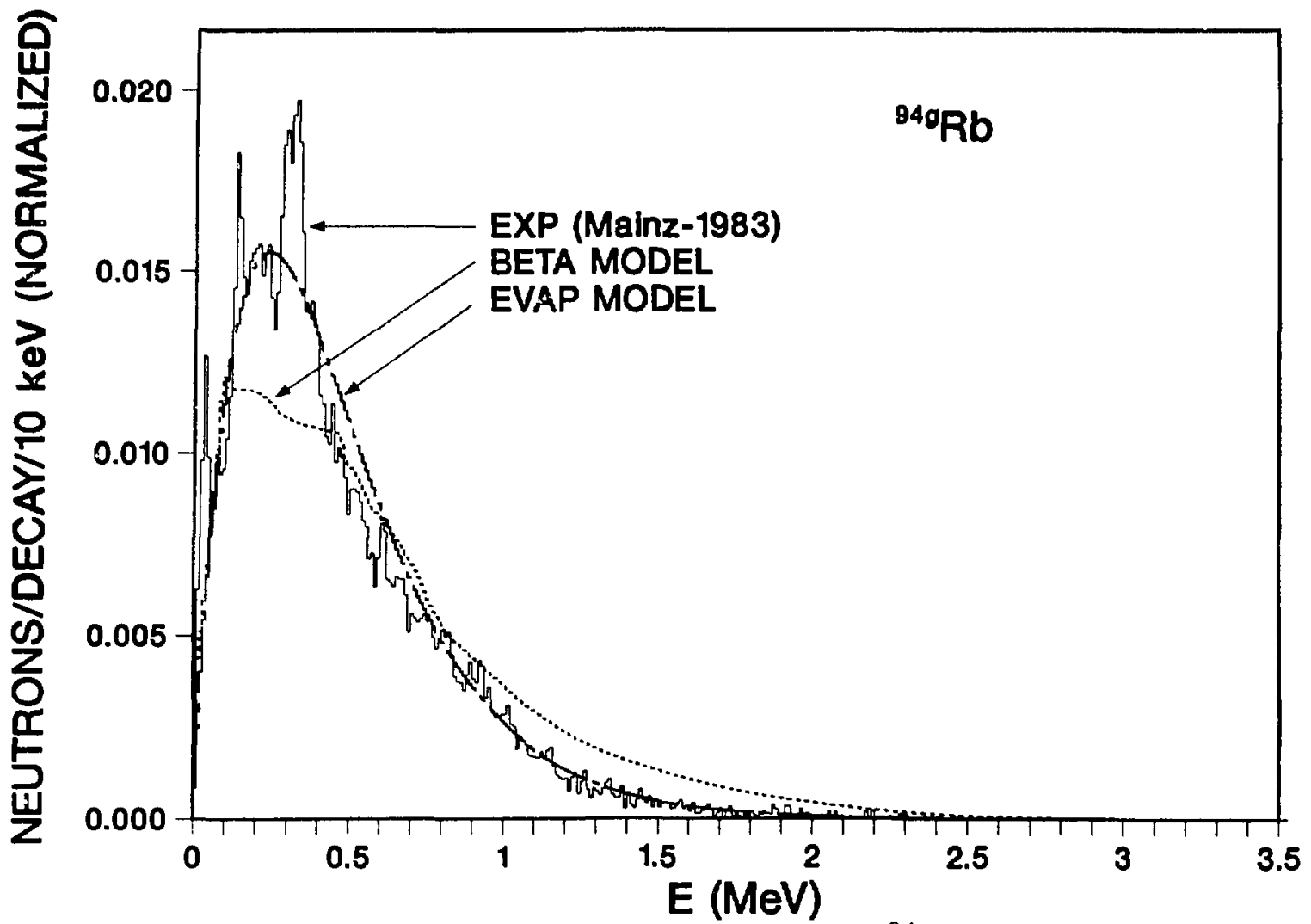

Fig. 6. Delayed neutron spectra for nuclide ${ }^{94} \mathrm{gRb}$.

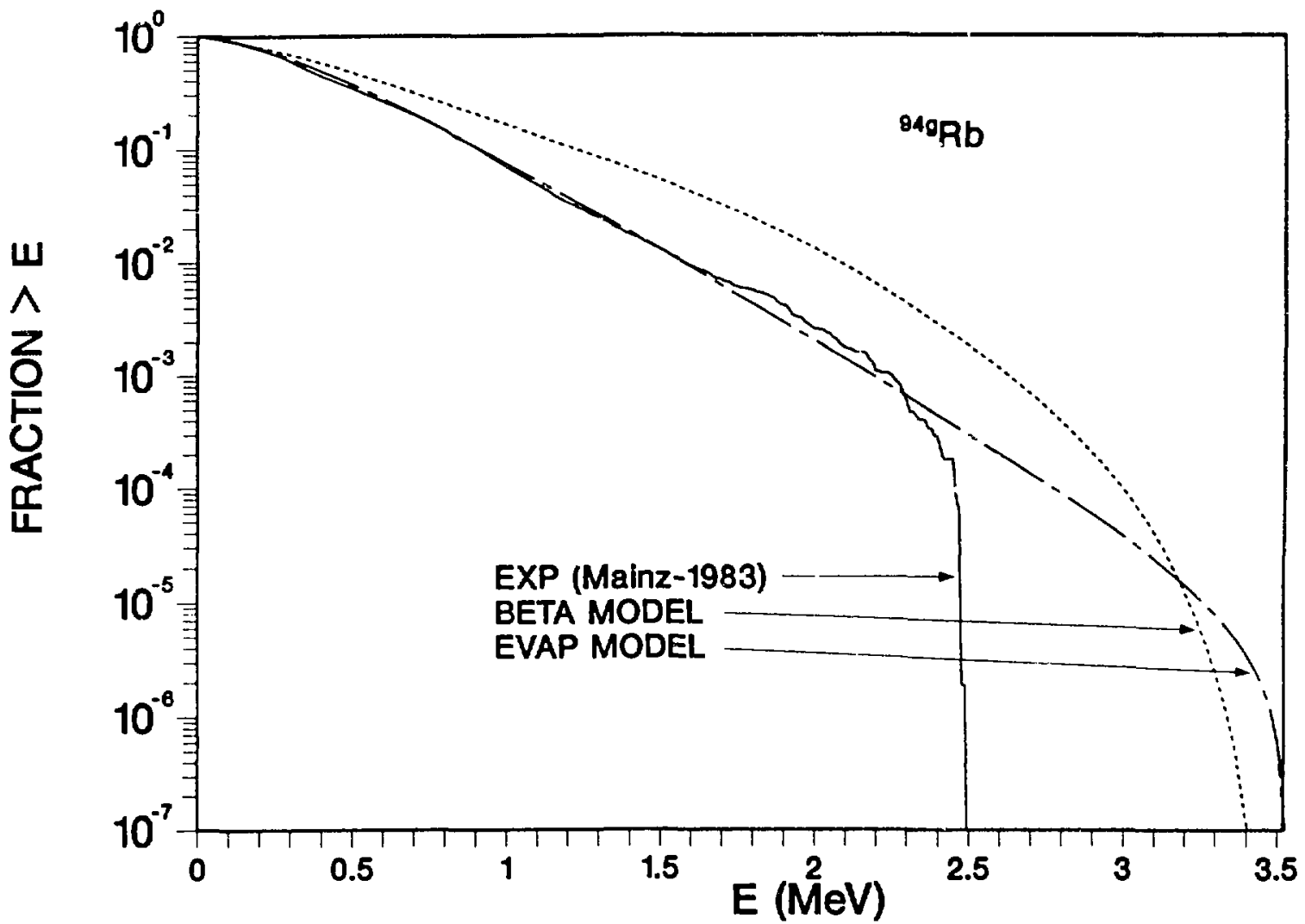

Fig. 7. Spectra as a fraction $>\mathrm{E}$ for nuclide ${ }^{94 \mathrm{gRb}}$. 


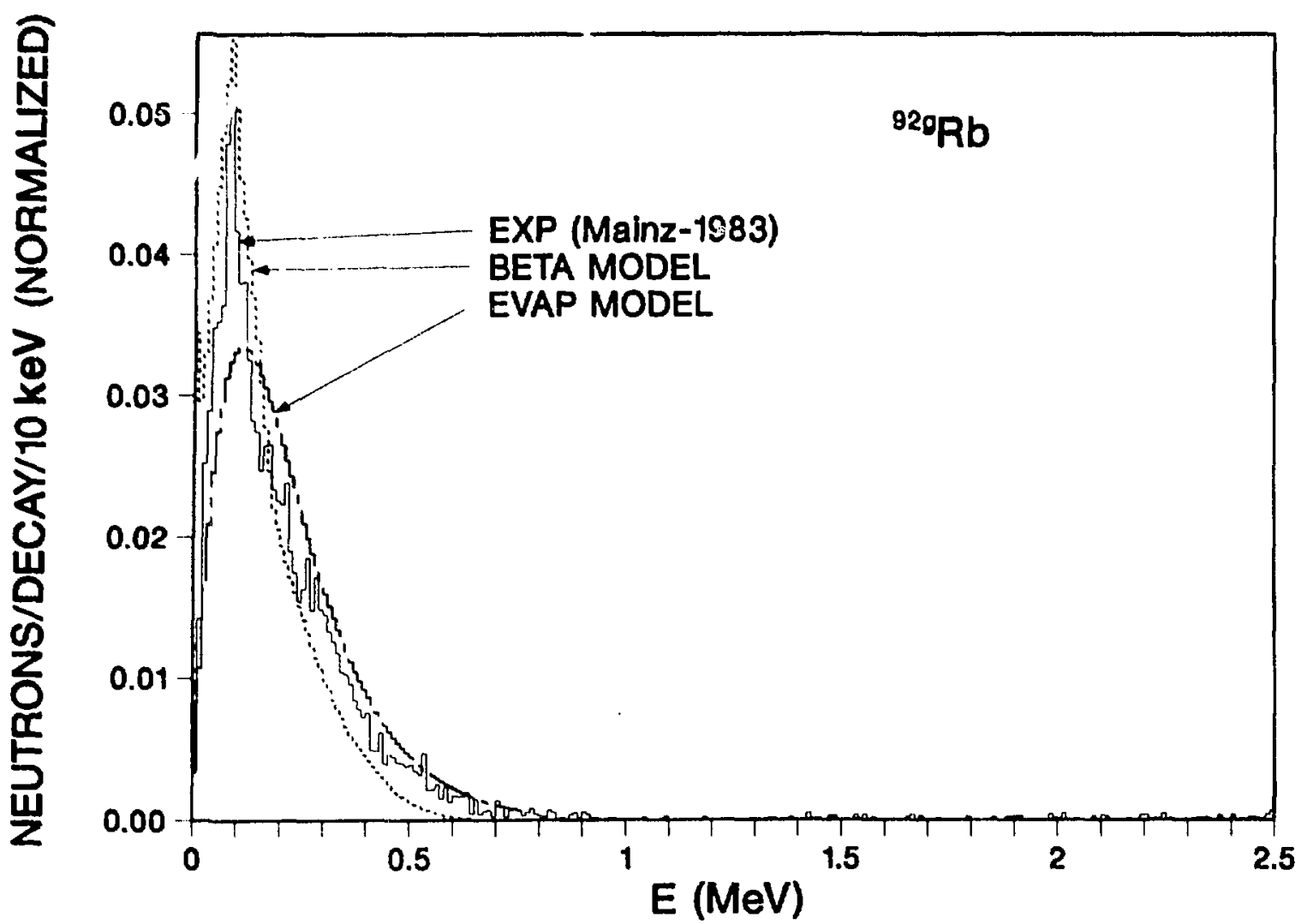

Fig. 10. Delayed neutron spectra for nuclide 928Rb.

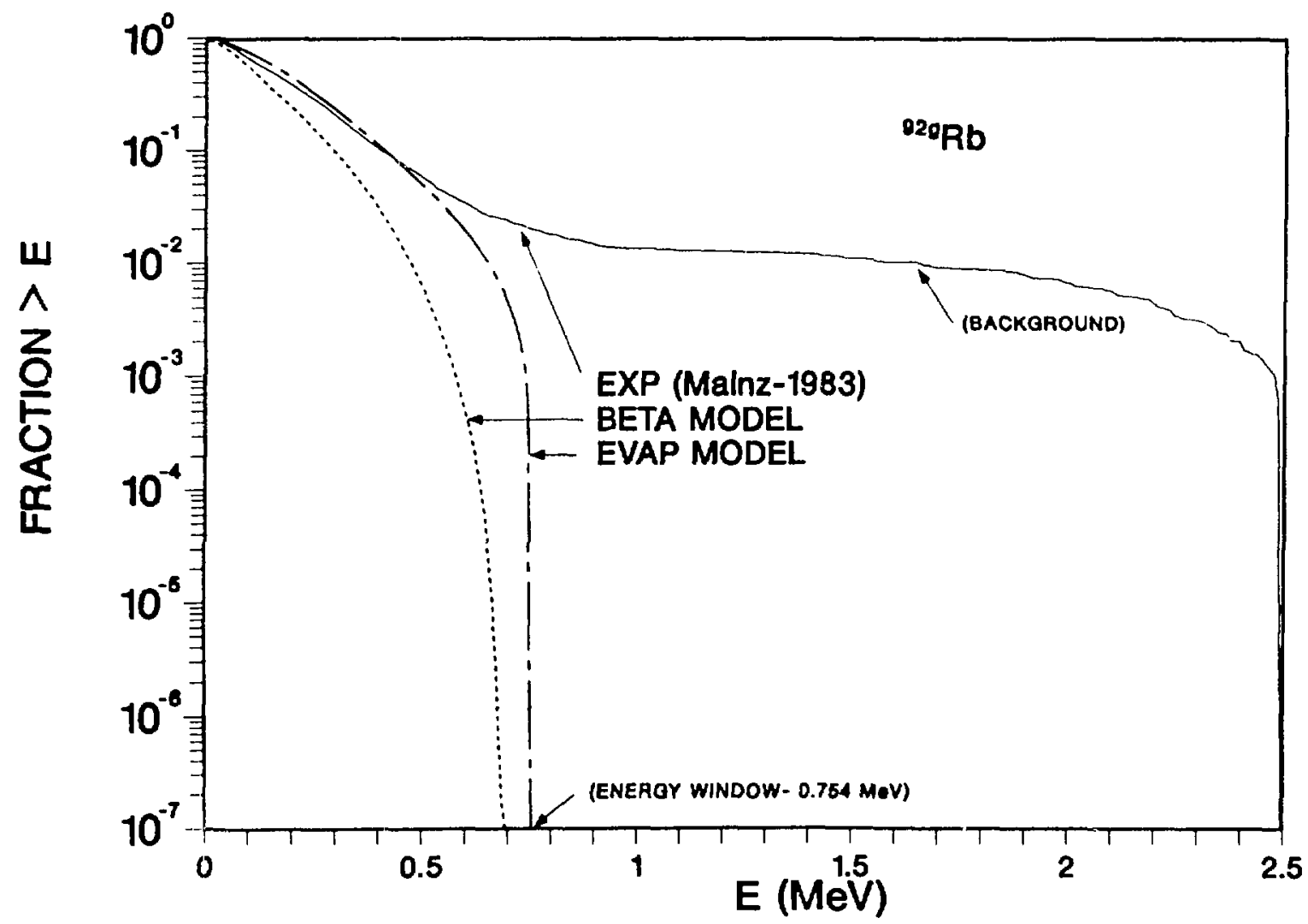

Fig. 11. Spectra as a fraction $>E$ for nuclide $92 \mathrm{gRb}$. 


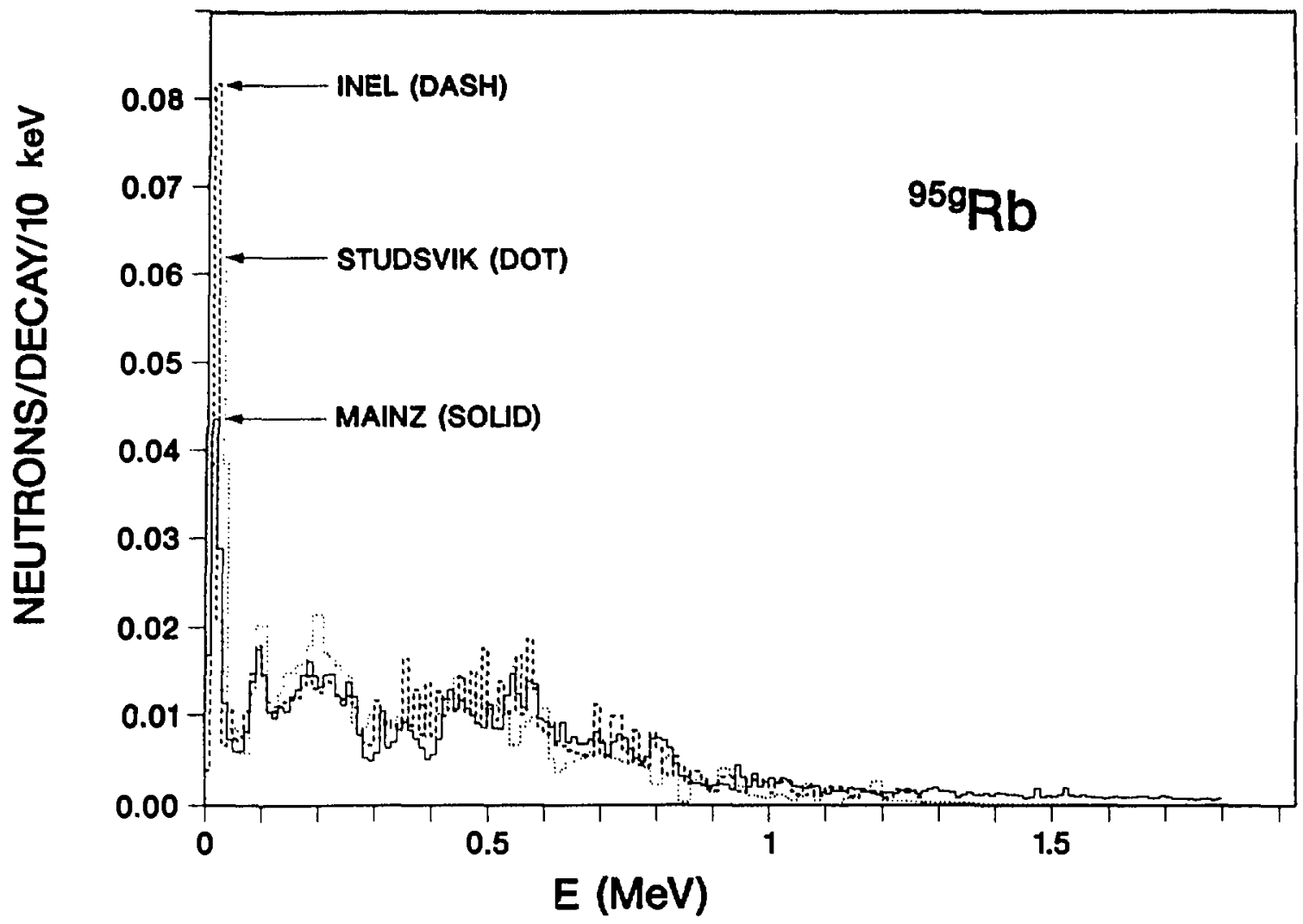

Fig. 12. Normalized delayed neutron spectra for ${ }^{95 g R b}$.

In Fig. 8 a primary problem occurring with existing measured spectra and our models is more evident. Measured spectra extend to only $\sim 2.5 \mathrm{MeV}$ and are normalized over this range; yet the energy window is $\sim 5.9 \mathrm{MeV}$. Here, the model spectra are clearly incorrect at low energies and the measured spectral range is probably inadequate. This is the case with at least 20 of the 34 measured spectra. Essentially all single measurements are likely to be incomplete in the sense of covering the total energy range. Thus, some are also inadequate at low energies $(\leq 100 \mathrm{keV})$, important in reactors. Attempts here to combine spectra suffer from the problem of normalizations, although this is less severe than suggested by Figs. 8 and 9. As noted earlier, measured spectra do include most of the neutrons but their energy range is usually inadequate.

Figures 10 and 11 illustrate a different, less common problem. The measured spectrum decidedly has a background that must be removed. This appears to be evident from the figures and must be so if the $0.754-\mathrm{MeV}$ energy window is correct.

Figure 12 compares three measured spectra. In this case, normalization affects the comparison of even the measured spectra, especially because of the very large differences in the 
low-energy peak, although there are real differences that are more evident when comparing ratios of various peaks; ratios are unaffected by normalization.

Our first objective in the current work has been to obtain a complete, fiducial set of precursor data, including data for all probable precursors and a complete energy range for the spectra. This has required some decisions that are in part subjective in the choice of spectral models, measured data to be combined, and the specific method of combination. Table III defines precisely what was combined or used for each precursor. In the case of more than one measurement being available, of the 34 precursors having measurements, we generally used the one covering the largest energy range. There are exceptions based on a comparison of uncertainties. The measurement was assumed to contain essentially all of the neutrons, and any model spectra were first renormalized to this dominant measurement, based on a small energy range defined in Table III. Results were then joined and the total spectrum was renormalized. The available hydrogen recoil measurements ( 8 precursors) made at Idaho National Engineering Laboratory (INEL) ${ }^{17}$ were assumed to be more correct at small energies than the data using ${ }^{3} \mathrm{He}$ spectrometry. 19,20 These were similarly joined below $200 \mathrm{keV}$, as were the model results (below approximately $100 \mathrm{keV}$ ) in 12 cases.

The combined spectra from models generally had little effect on the initial experimental data, as is evident in Fig. 13 where the dashed and solid plots are essentially the same. The range of results from various other combinations is illustrated by Figs. 13-16.

The BETA code ${ }^{18}$ was combined only with the 34 measured spectra where it could be normalized to a small range of measured data. This code is described in Ref. 18, as well as in Ref. 13, where it was used extensively. From the previous comparisons, the code clearly needs improvement before using it where no measured data exist to replace its low-energy predictions. Rather, most spectra have a general shape that can be approximated by a simple evaporation model.

The following evaporation model was employed for the 231 precursors having unmeasured spectra:

$$
n_{d}(E)=C\left\{E e^{-E / T}-\left(Q_{\beta}-S(n)\right) e^{-a T}\right\}
$$

where

$$
\left(Q_{\beta}-S(n)\right)=a T^{2}
$$

From Eq. (2), the average energy is $\bar{E} \cong 2 T$. We used the known spectra to derive an average energy and to then find a value of "a" in Eq. (3), based on the $Q_{\beta}$ and $S(n)$ values. The results were used to find a general correlation between " $a$ " and the nuclide mass number:

$$
a \cong 2 / 3 \mathrm{~A} \text {. }
$$


Based on this and on Eq. (3), the temperature we derived is listed in Table III for each precursor in which the spectra are noted as being "EVAP," i.e., derived from Eq. (2).

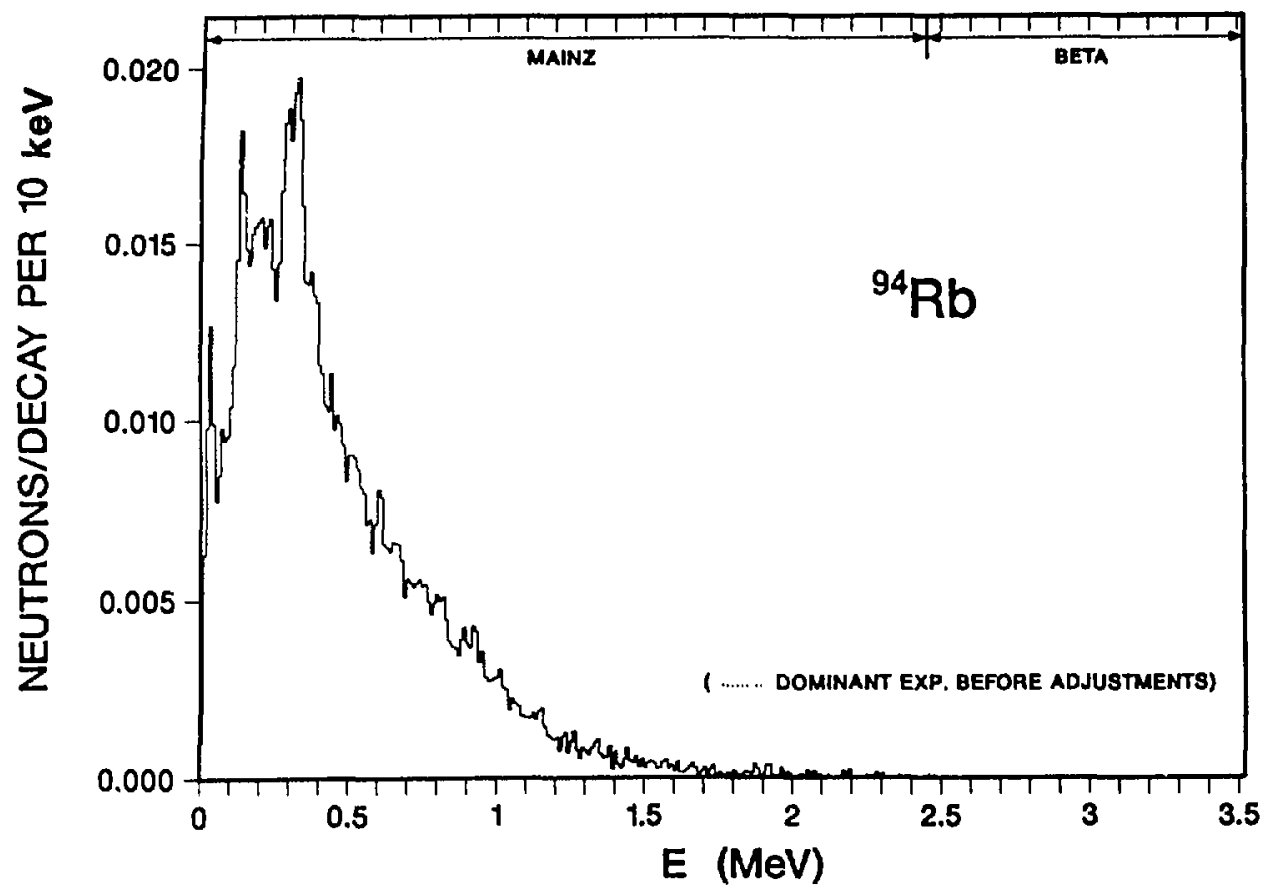

Fig. 13. Normalized delayed neutron spectra for ${ }^{94} \mathrm{Rb}$.

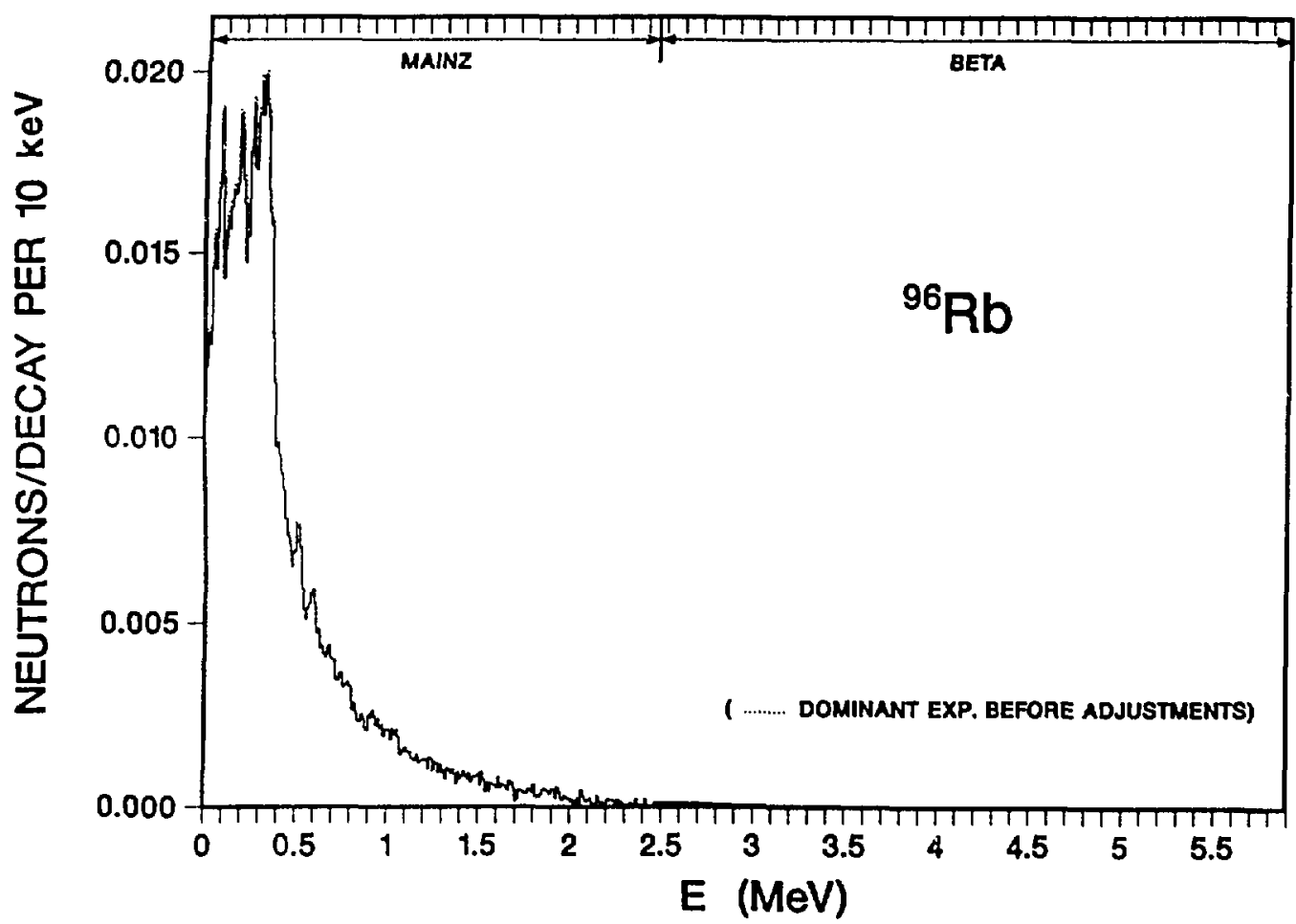

Fig. 14. Normalized delayed neutron spectra for ${ }^{96} \mathrm{Rb}$. 


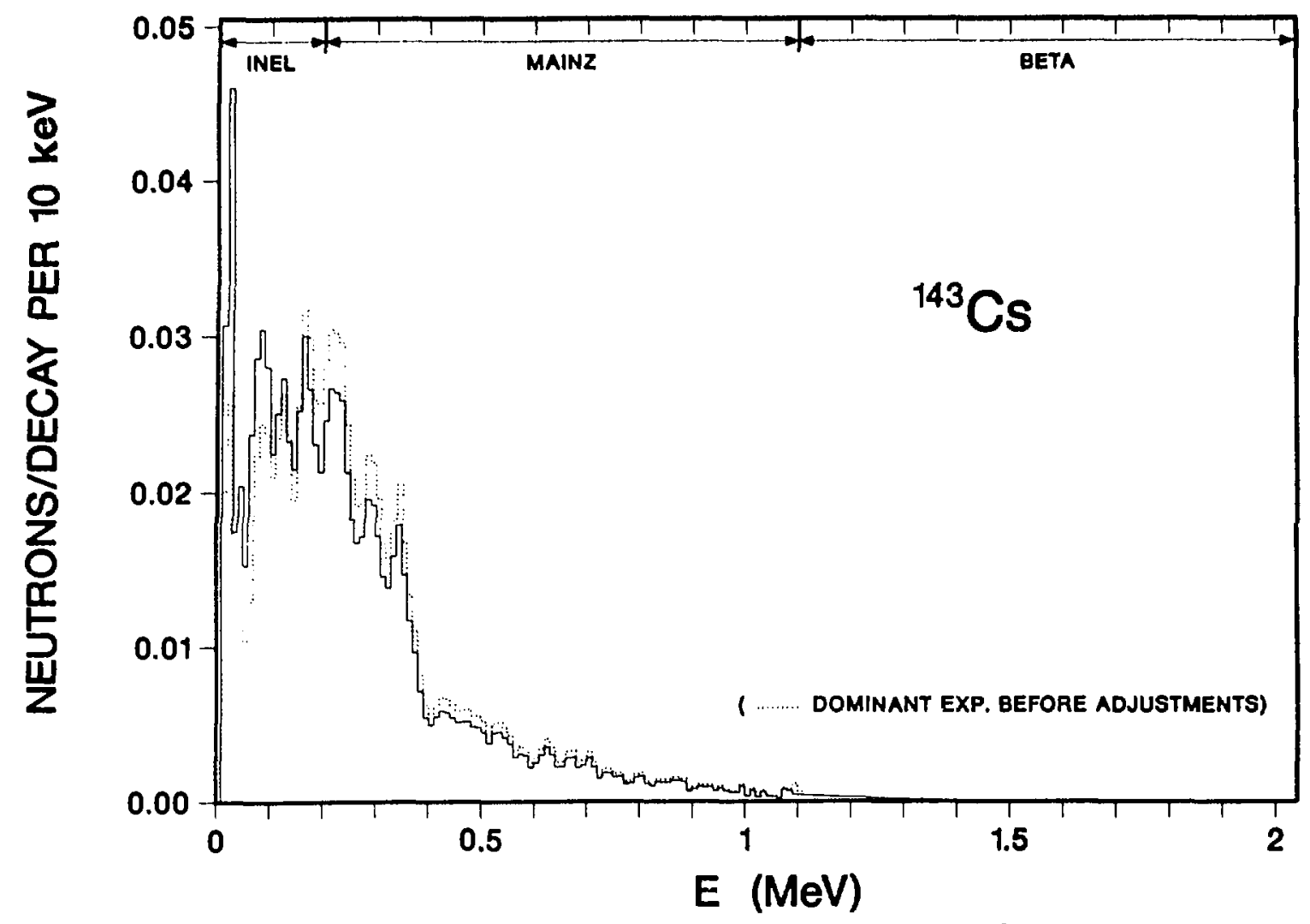

Fig. 15. Normalized delayed neutron spectra for ${ }^{143}$ Cs.

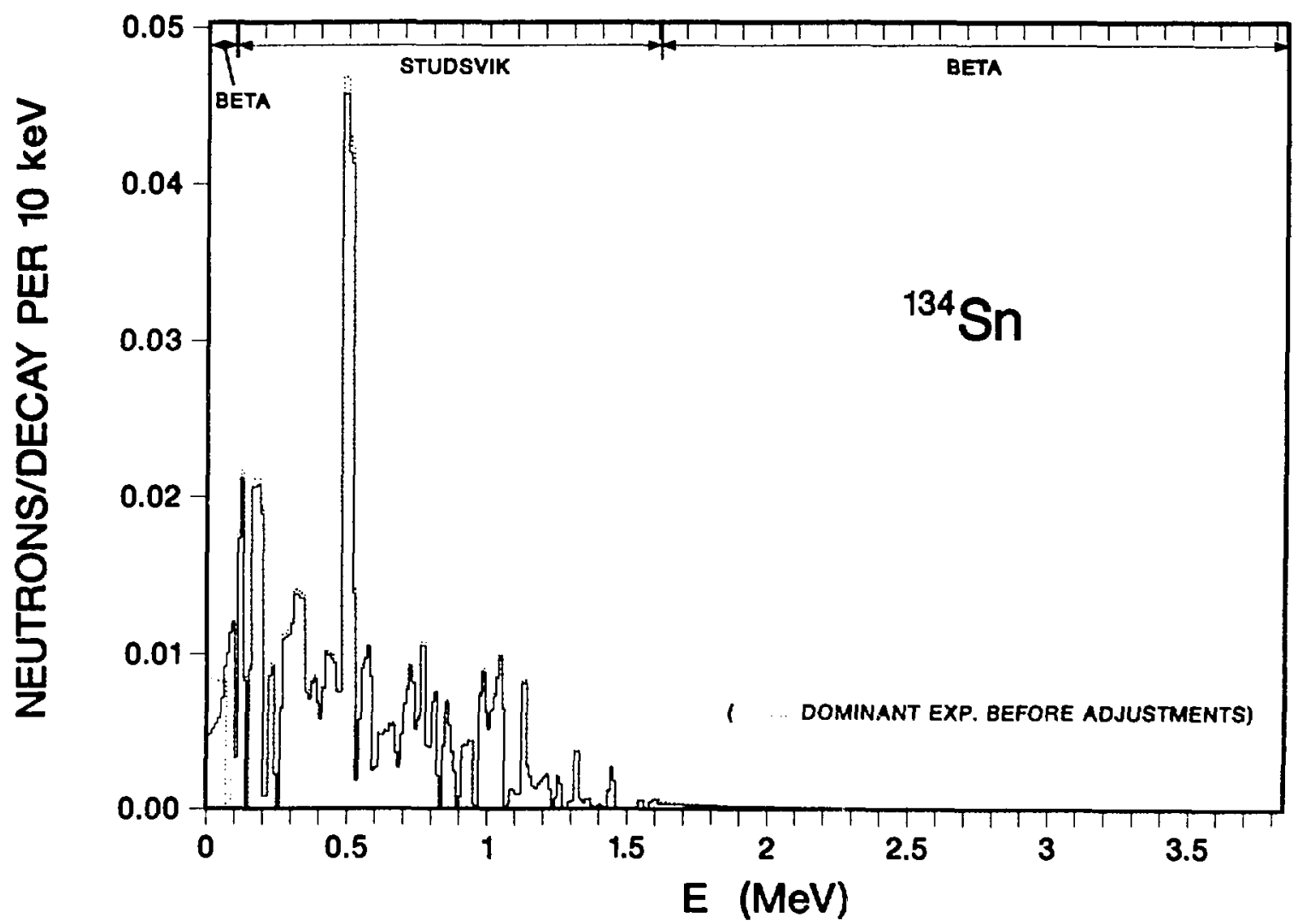

Fig. 16. Normalized delayed neutron spectra for ${ }^{134} S$. 
In an attempt to verify the general validity of the extended spectra, a measurement was made of ${ }^{96} \mathrm{Rb}$ and ${ }^{97} \mathrm{Rb}$. Results from Ref. 16 show a preliminary comparison with our spectra converted to counts/channel in Figs. 17-18. More recently, we compared the ${ }^{96} \mathrm{Rb}$ as an energy plot with the measured spectra extended by both the BETA code and evaporation models, as shown in Fig. 19. The measured spectra fall between the two extensions. (Here, the measured spectra were normalized to earlier and more detailed measurements of $\mathrm{Kratz}^{19}$ over their common energy range.) From Figs. 17-19, the higher energy neutrons are obviously present, but there is a large uncertainty in any particular spectrum. The aggregate spectra could be significantly larger or smaller than values shown in Section IV.

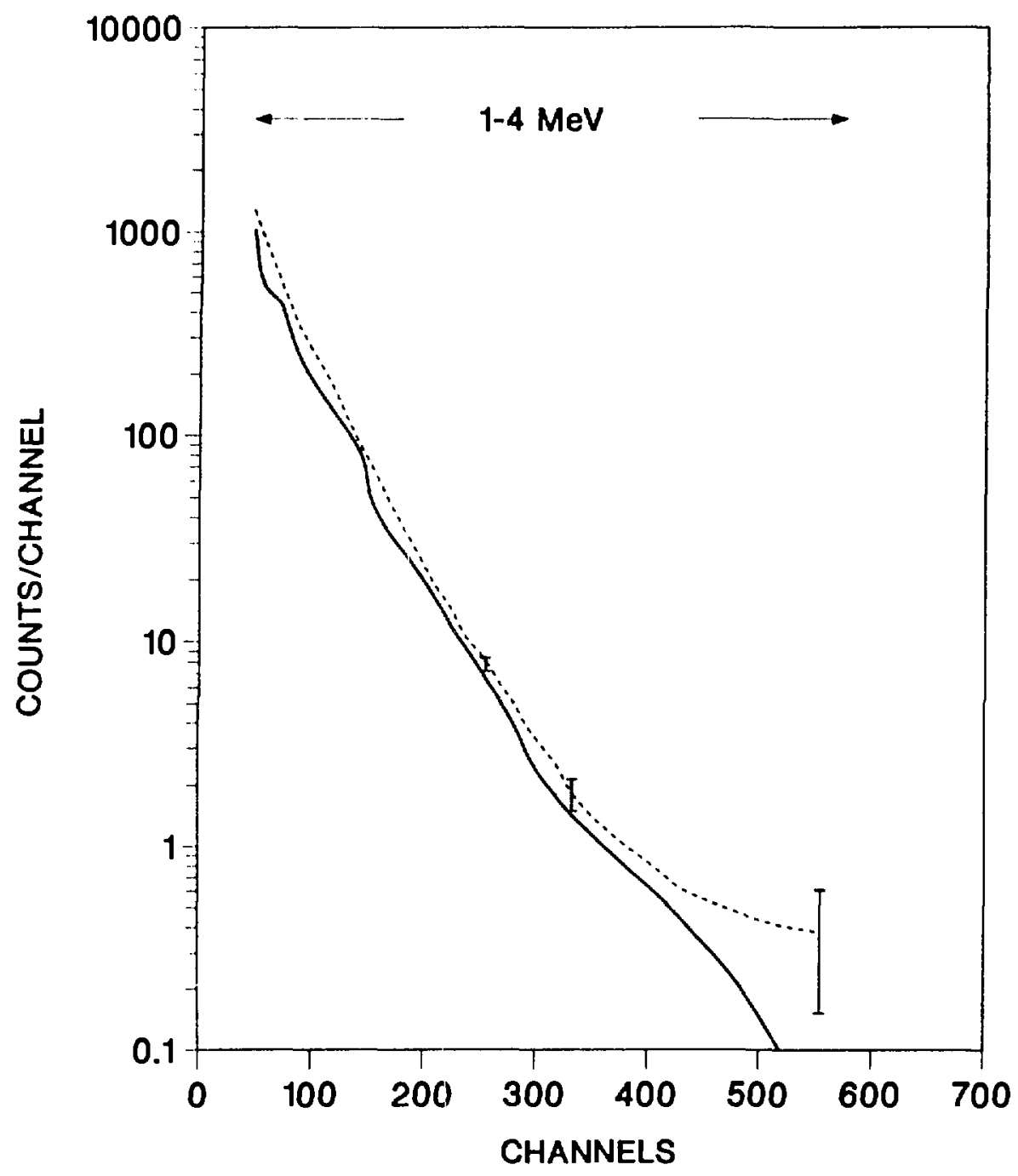

Fig. 17. ${ }^{96} \mathrm{Rb}$ Delayed neutron spectrum. 


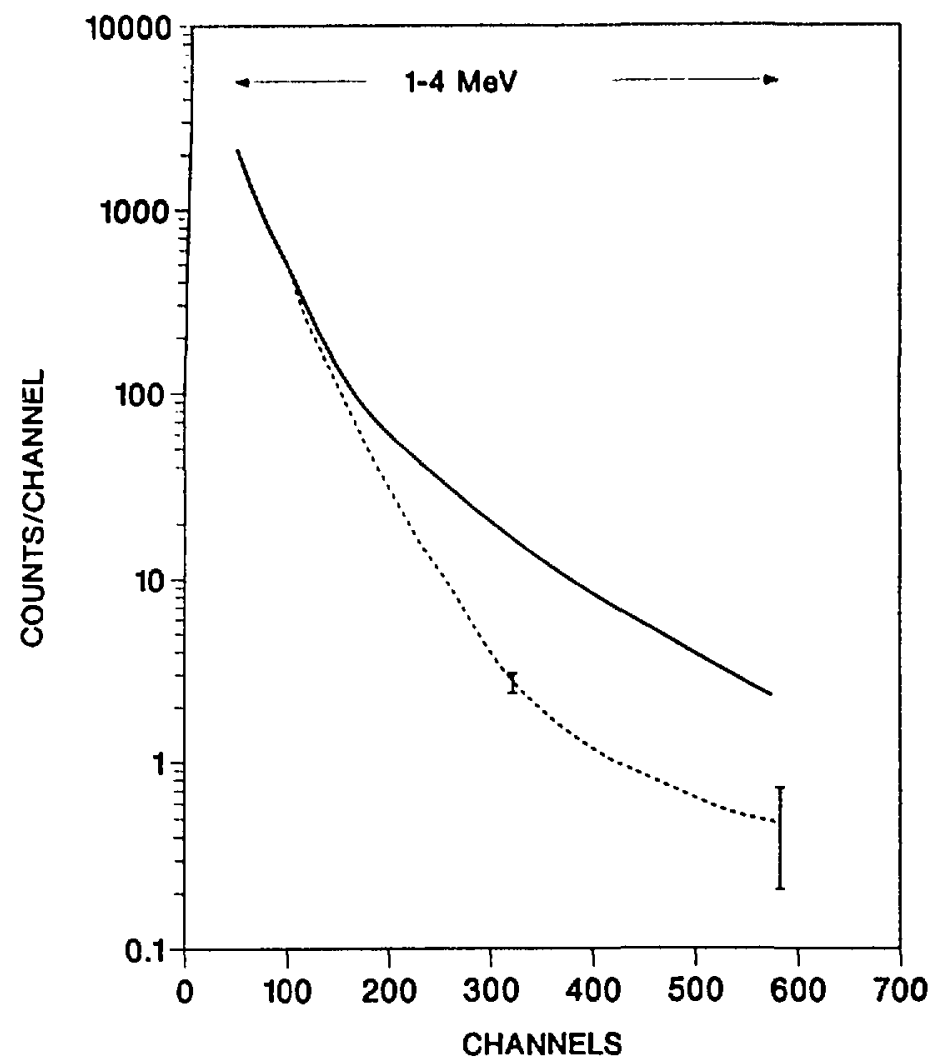

Fig. $18 .{ }^{97} \mathrm{Rb}$ delayed neutron spectrum.

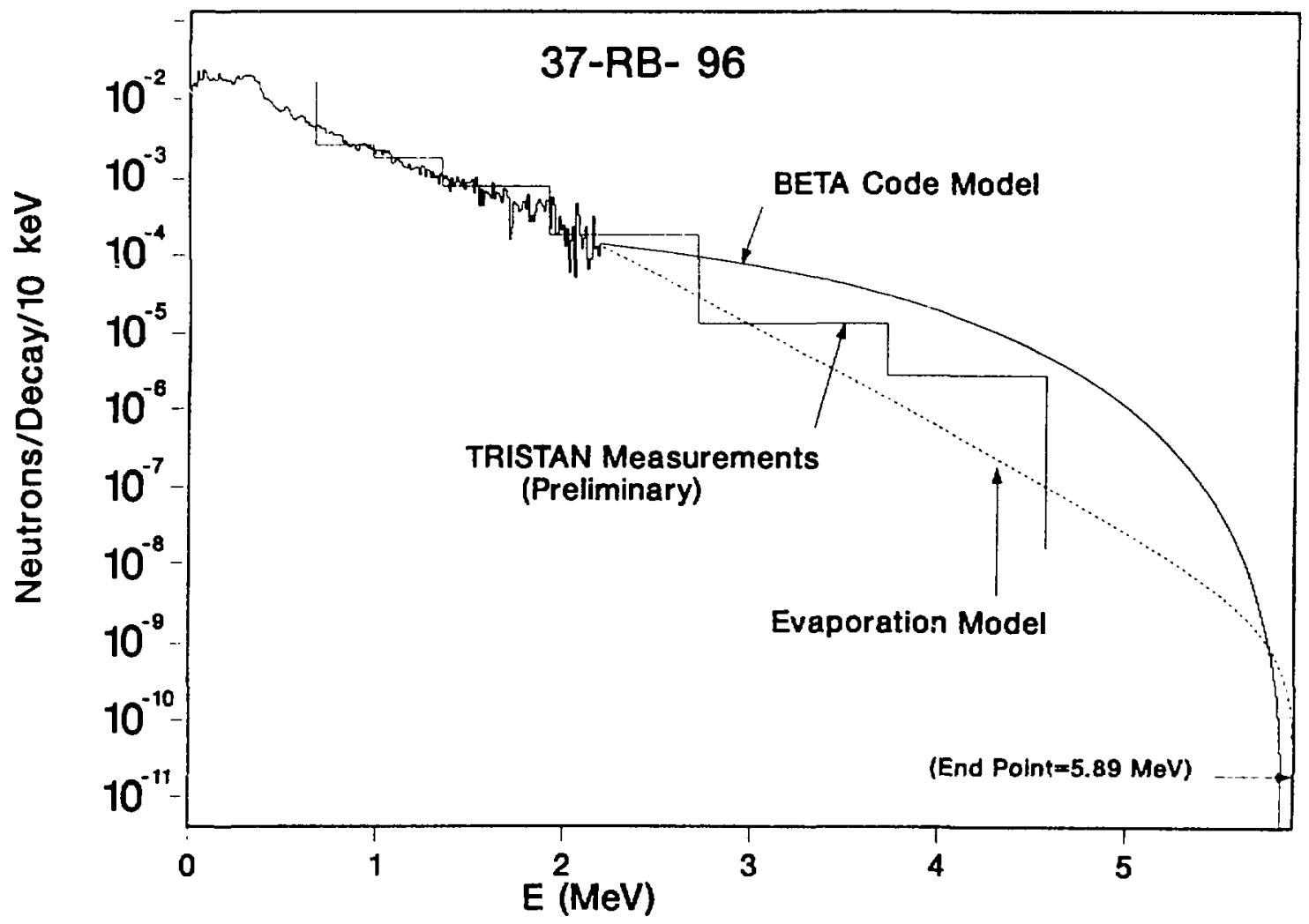

Fig. 19. Comparison of delayed neutron spectra for ${ }^{96} \mathrm{Rb}$. 
Prior to 1986 there were no aggregate measurements $\geq 1.6 \mathrm{MeV}$. Very preliminary measurements were made at Los Alamos for ${ }^{235} \mathrm{U}$ samples irradiated by bursts from the Godiva reactor. Results reported in Ref. 16 are shown in Figs. 20-22, where the histograms are the measured spectra and the solid lines are our calculated results in 1986. Again, results are very uncertain at high energies but demonstrate the existence of the high-energy delayed neutrons.

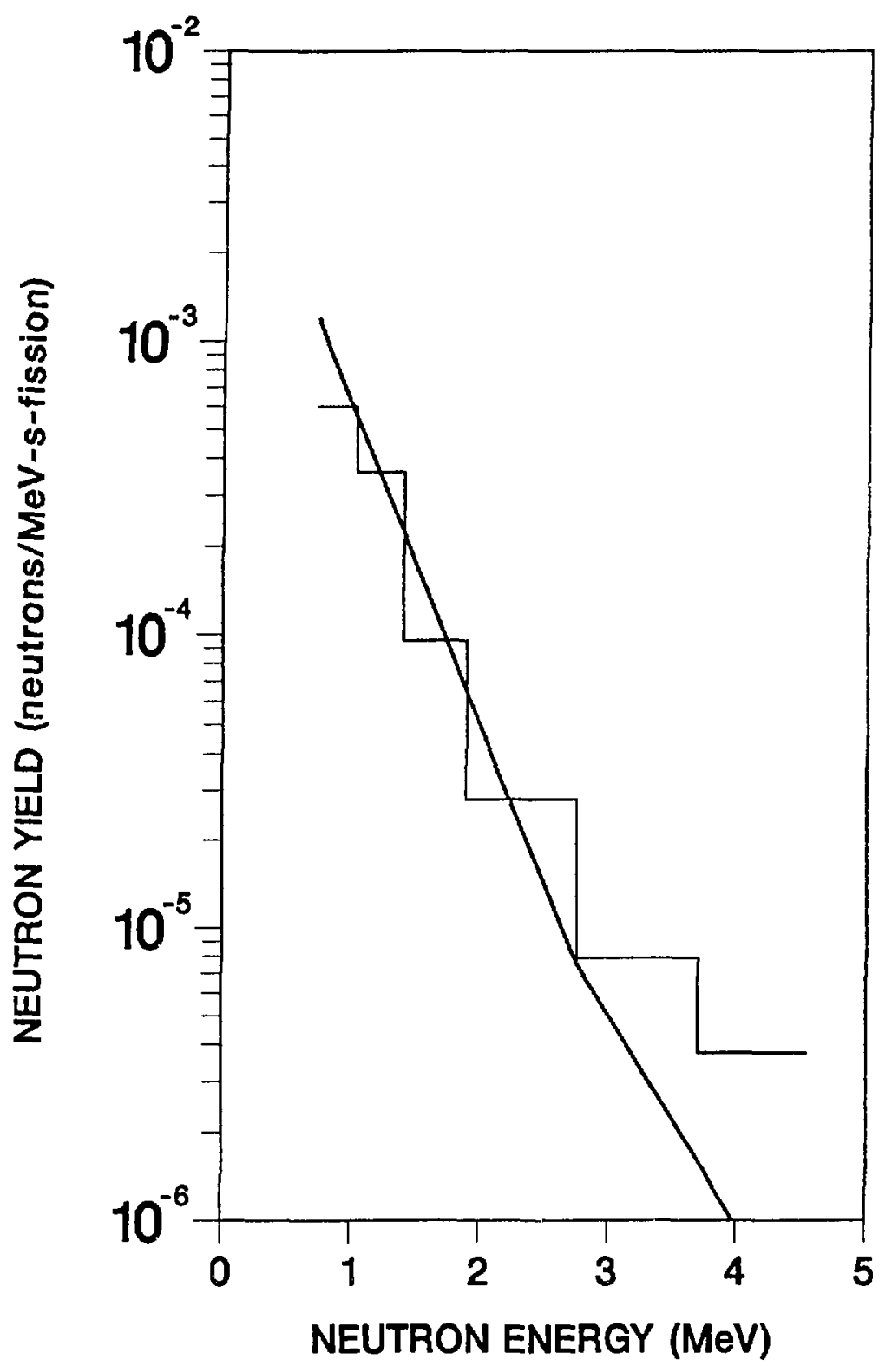

Fig. 20. Neutron spectrum, 1-5 s after Godiva burst. 


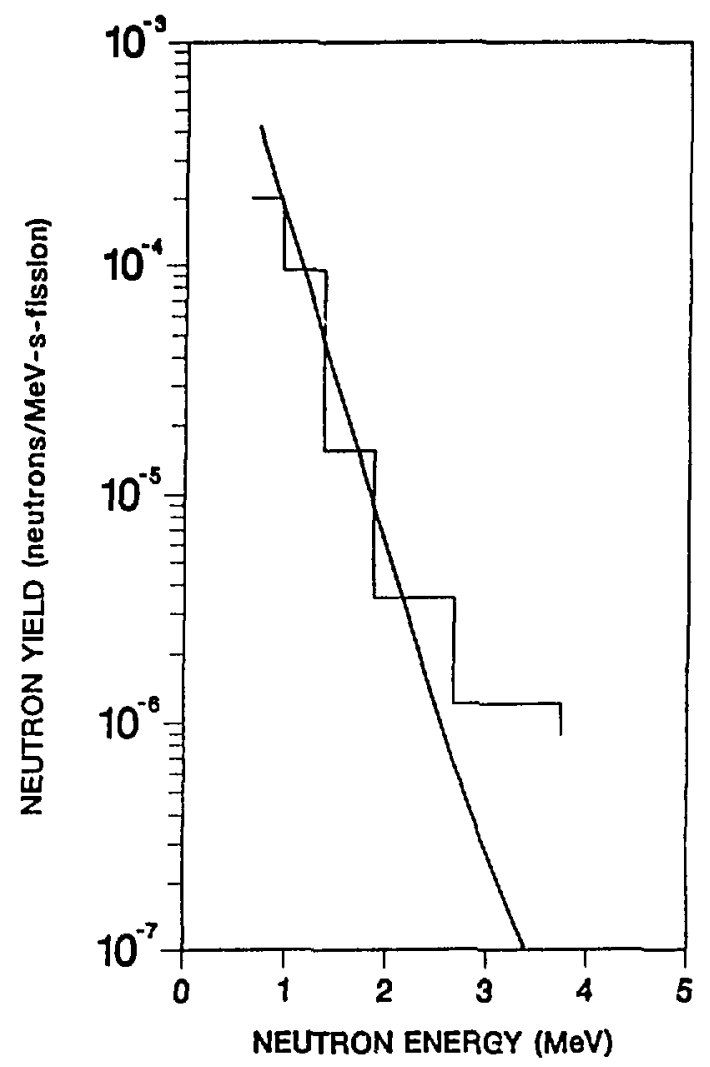

Fig. 21. Neutron spectrum, 5-10 s after Godiva burst.

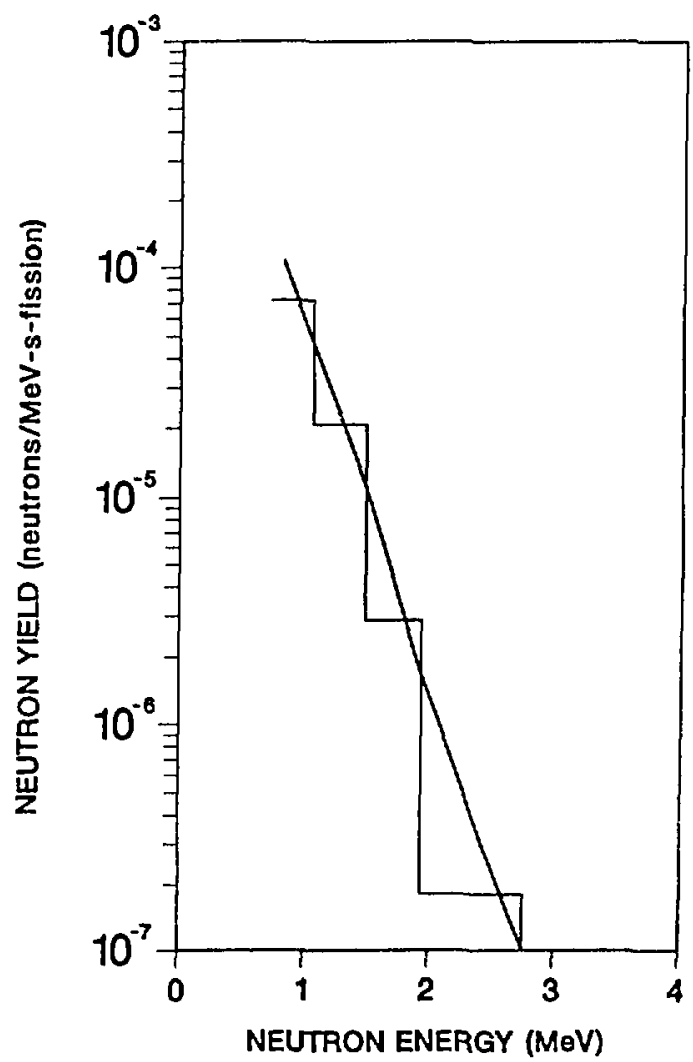

Fig. 22. Neutron spectrum, 10-20 s after Godiva burst. 


\section{CALCULATED $\nabla_{d}$ SPECTRA FROM FISSION PULSES}

All of the data discussed in Section III were used in the CINDER-10 code to calculate the 271 precursor activities vs time following a fission pulse. The code includes all known fission products coupled together by all known decay branching. There is no approximation in the calculation other than the accuracy of the input data.

Normalized spectra and $\mathrm{Pn}$ values are folded into the precursor activities at various times to produce aggregate spectra and integrated delayed neutron rates for several fissioning species.

The fission pulse consists of $1.3 \times 10^{26}$ fissions over $10^{-4} \mathrm{~s}$. Table IV is an exception. Here, total $\nabla_{\mathrm{d}}$ values at time zero are based on 100 fissions for each of 42 fissioning species. This table was actually produced using the Pn values, direct fission yields, and precursor halflives. Such calculations are relatively simple, but cannot describe the subsequent temporal variations in totals or in aggregate spectra. Table IV does show the importance of various fissioning systems except for hardness of the spectrum; and we have used these results to verify the CINDER-10 calculations at time $\sim 0$ (calculated results labelled as time $=0$ are actually values that apply at $10^{-4}$ s).

The temporal variation of each of these 42 cases has been calculated. In this report we primarily include the results for four fuels: $235 \mathrm{U}, 238 \mathrm{U},{ }^{239} \mathrm{Pu}$, and ${ }^{232} \mathrm{Th}$--all at fast or fission neutron energies. These bracket the range of calculated spectra. Figure 23 does show the total $\nabla_{d}$ rate vs time for eight of the fuels.

Figure 24 shows a comparison of the $235 \mathrm{U}$ spectra at $5 \mathrm{~s}$ cooling before and after spectral expansions. Also included is an independent calculation made by A. Sierk ${ }^{14}$ using a totally statistical approach to both spectra and fission yields as a check on the general validity of results in this report.

Figures 25-28 show the spectrum for each of four fuels as a fraction of the delayed neutron rate remaining above the abscissa energy. Values at nine decay times are plotted. Total values'and average energies are included on the plots. Figures 29-31 compare these fractions for each fuel at 1,5 , and $10 \mathrm{~s}$ and Figs. 32 and 33 show the same data in more detail above $4 \mathrm{MeV}$.

The inclusion of ${ }^{232} \mathrm{Th}$ is based on its total $\nabla_{\mathrm{d}}$ rate. When the total spectrum is compared with ${ }^{238} \mathrm{U},{ }^{232} \mathrm{Th}$ is the larger value at most times. This is shown at three times in the comparisons of Figs. 34-36. ${ }^{239} \mathrm{Pu}$ is smaller at all times and energies. The range of spectra above $4 \mathrm{MeV}$ found for the eight fuels plotted in Fig. 23 is shown in Fig. 37 at 5-s decay. 


\section{TABLE IV}

DELAYED NEUTRON YIELD RATE PER 100 FISSIONS AT $t=10^{-4} \mathrm{~s}$

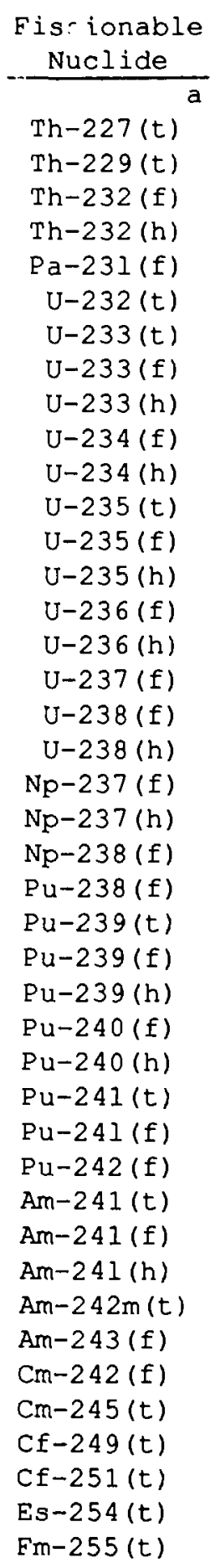

\author{
Current \\ Calculated Values \\ per 100 Fissions
}

$0.37 e+00$

$0.51 e+00$

$0.31 e+01$

$0.25 e+u 1$

$0.48 e+00$

$0.12 e+00$

$0.68 e+00$

$0.29 e+00$

$0.24 \mathrm{e}+00$

$0.49 e+00$

$0.28 e+00$

$0.10 e+01$

$0.98 \mathrm{e}+00$

$0.47 e+00$

$0.12 e+01$

$0.77 e+00$

$0.22 e+01$

$0.29 \mathrm{e}+01$

$0.19 e+01$

$0.51 e+00$

$0.52 \mathrm{e}+00$

$0.12 e+01$

$0.32 e+00$

$0.29 e+00$

$0.29 e+00$

$0.16 e+00$

$0.36 e+00$

$0.23 e+00$

$0.70 e+00$

$0.74 e+00$

$0.79 e+00$

$0.22 e+00$

$0.20 e+00$

$0.11 \mathrm{e}+00$

$0.33 e+00$

$0.32 e+00$

$0.47 e-01$

$0.30 e+00$

$0.51 e-01$

$0.25 e+00$

$0.19 e+00$

$0.67 e-01$

$\mathrm{a}(\mathrm{l},(\mathrm{f})$, and $(\mathrm{h})$ refer to thermal, fast (fission spectrum), and 14-MeV neutron fission energies. 


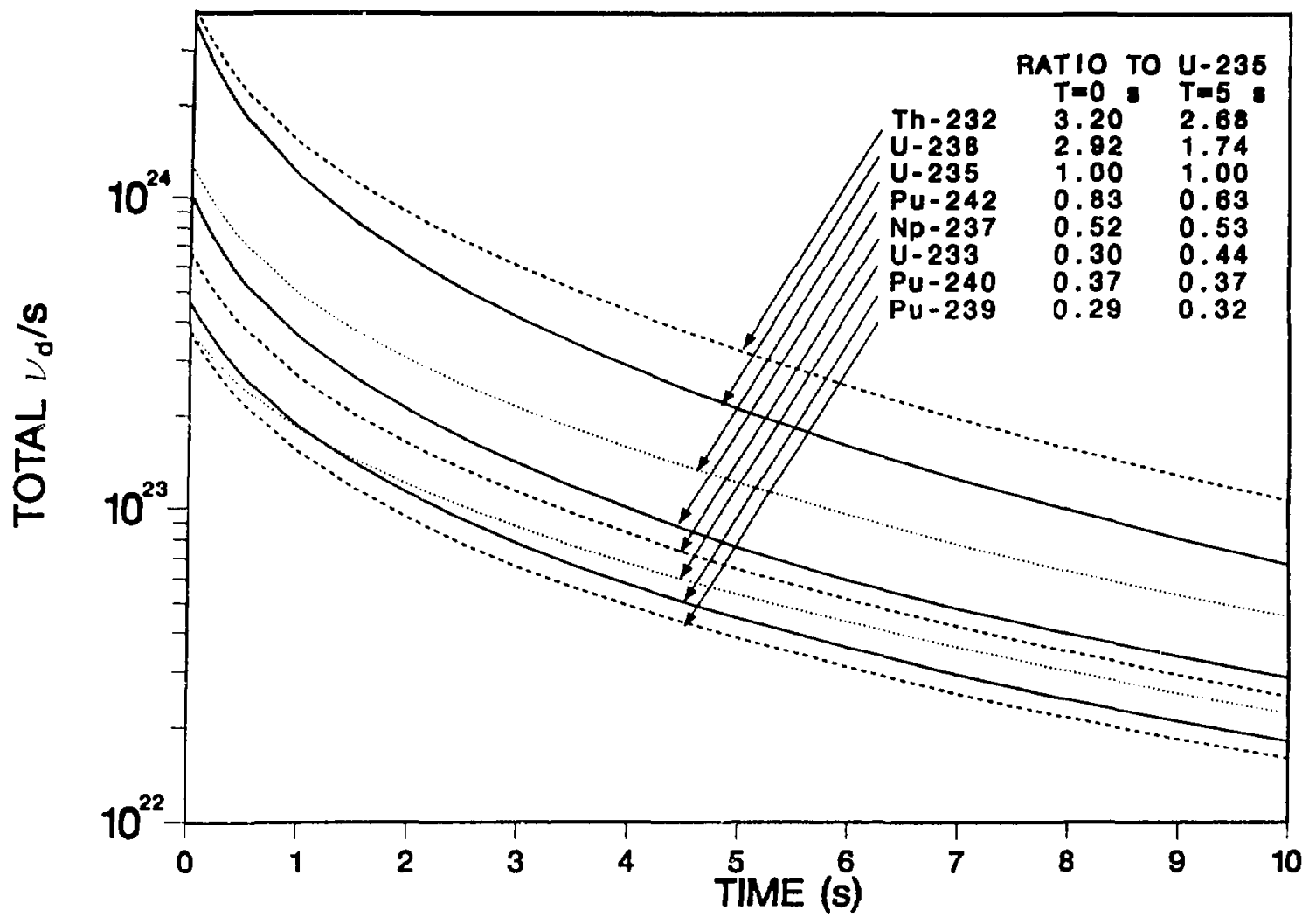

Fig. 23. Total $v_{d} / s$ for eight fuels vs time (pulse).

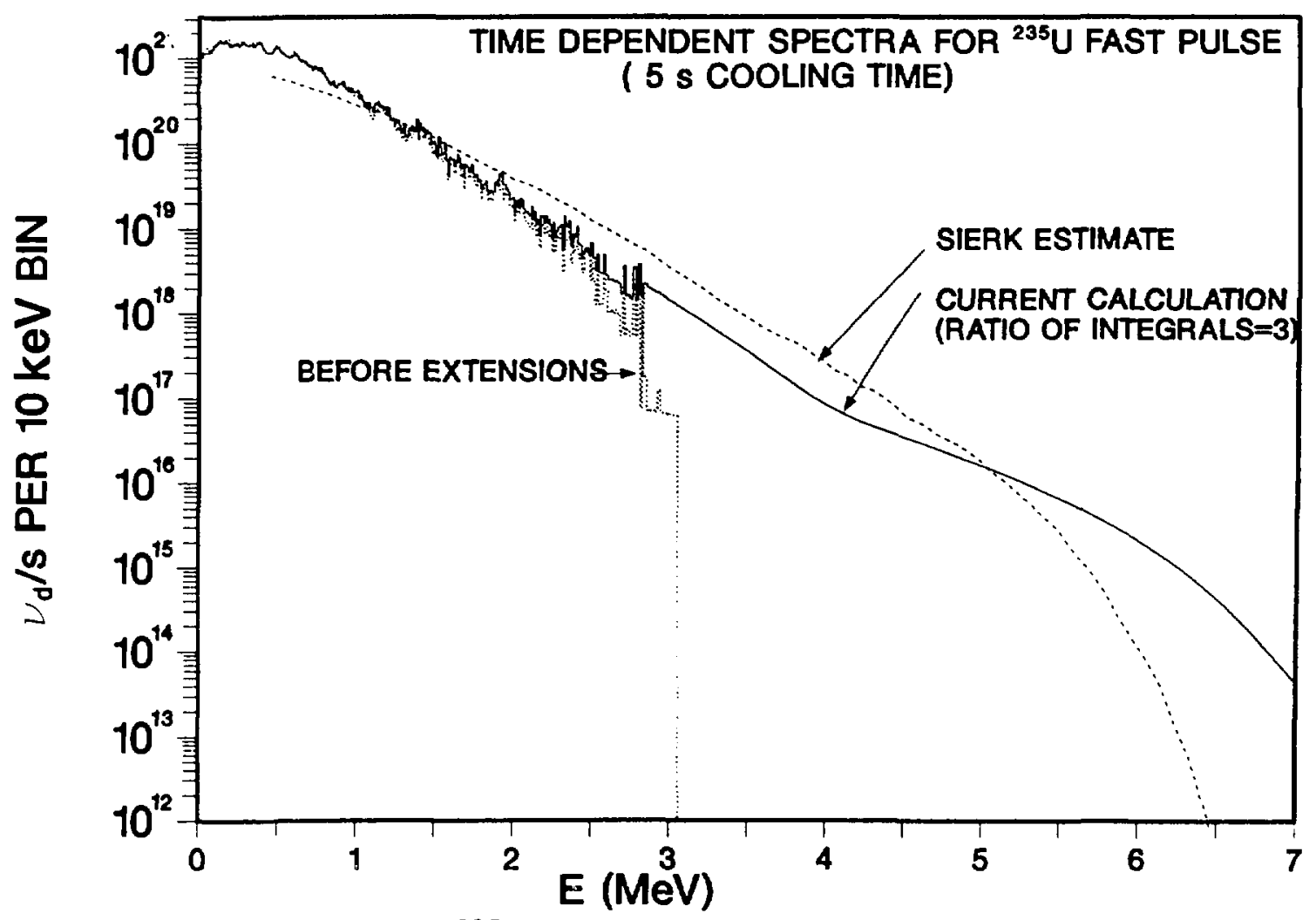

Fig. 24. ${ }^{235} U v_{d}$ spectra comparisons at $5 \mathrm{~s}$. 


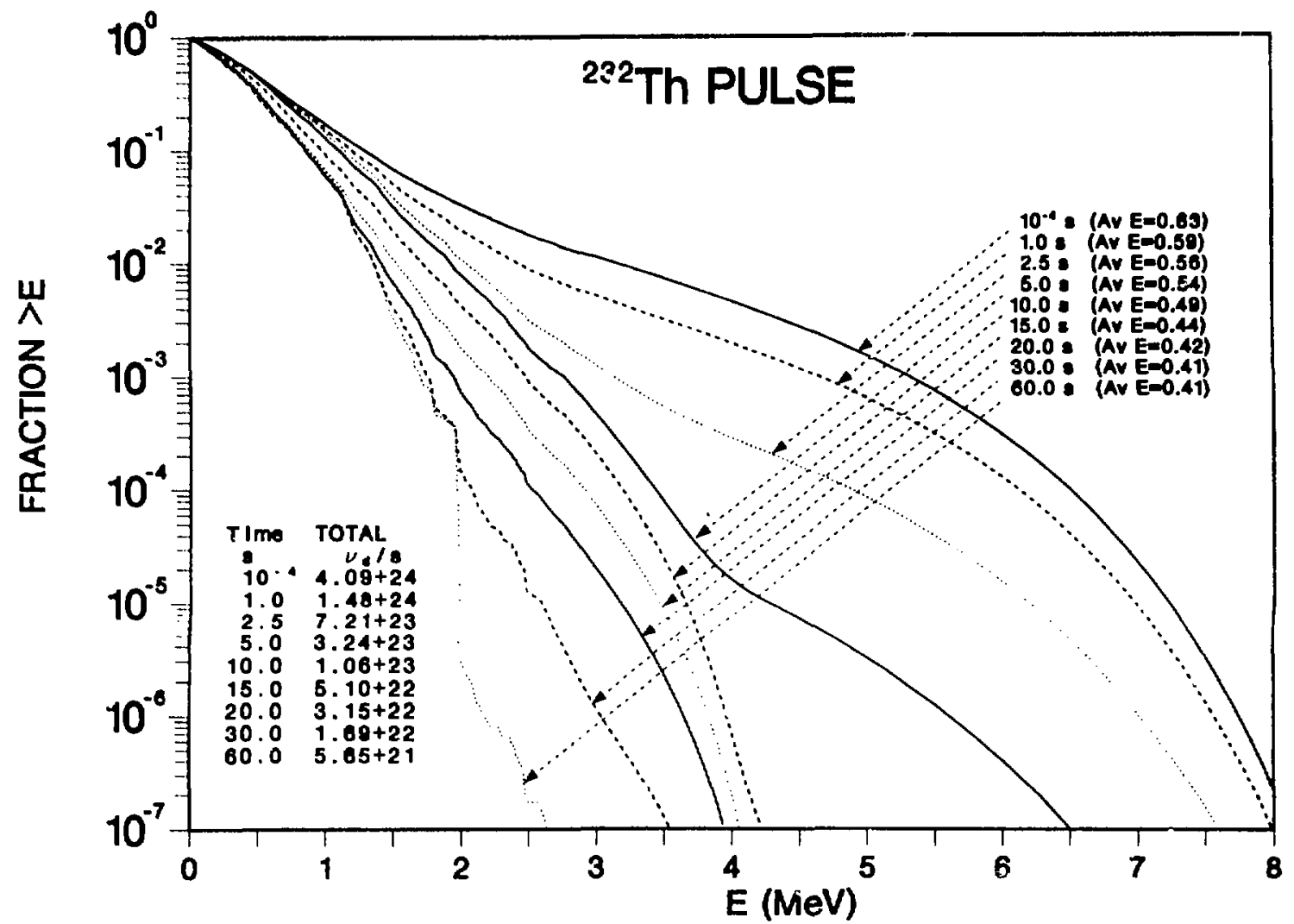

Fig. 25. $232 \mathrm{Th}$ fraction of total delayed neutrons $>E$.

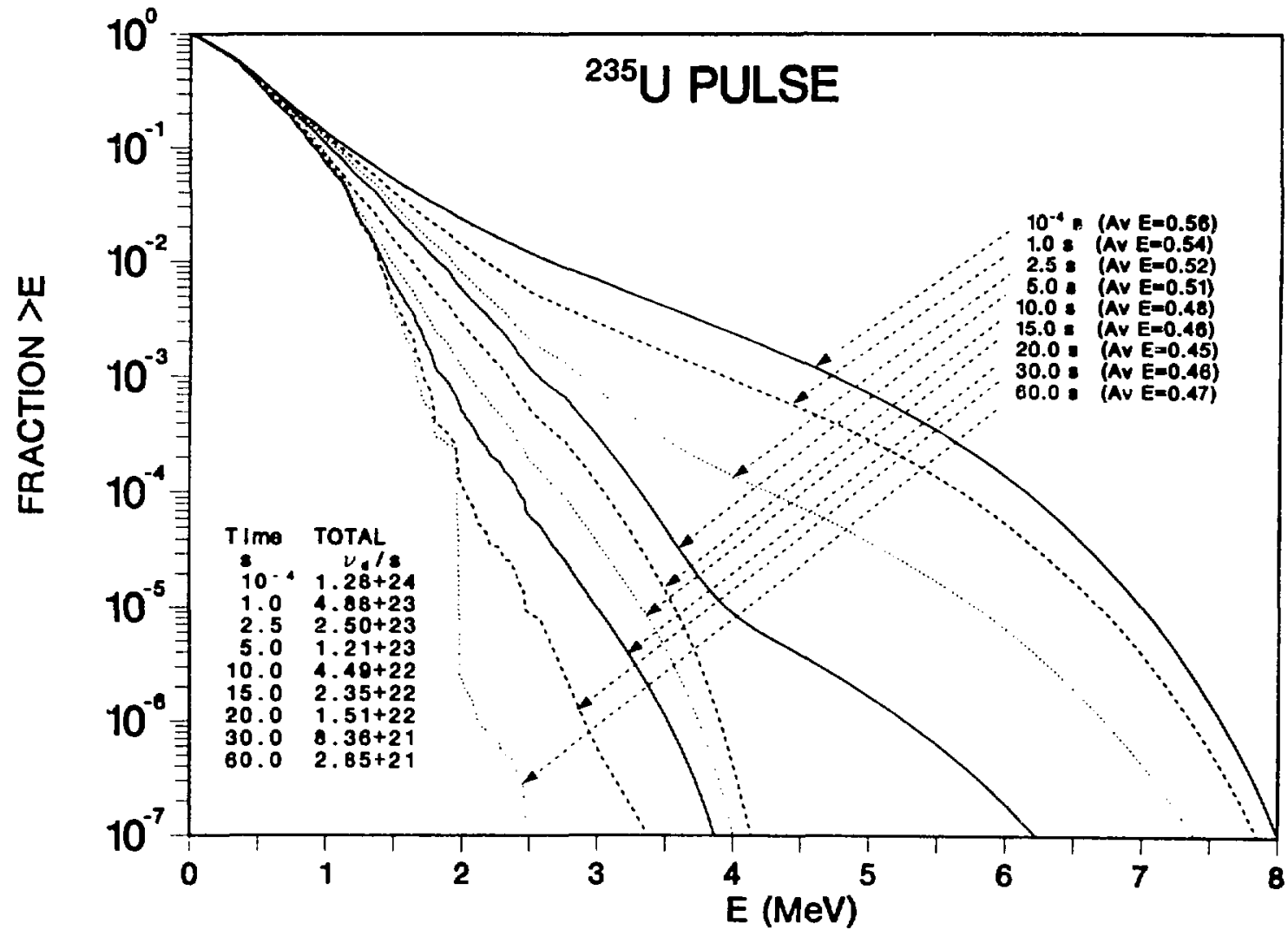

Fig. 26. ${ }^{235 U}$ fraction of total delayed neutions $>E$. 


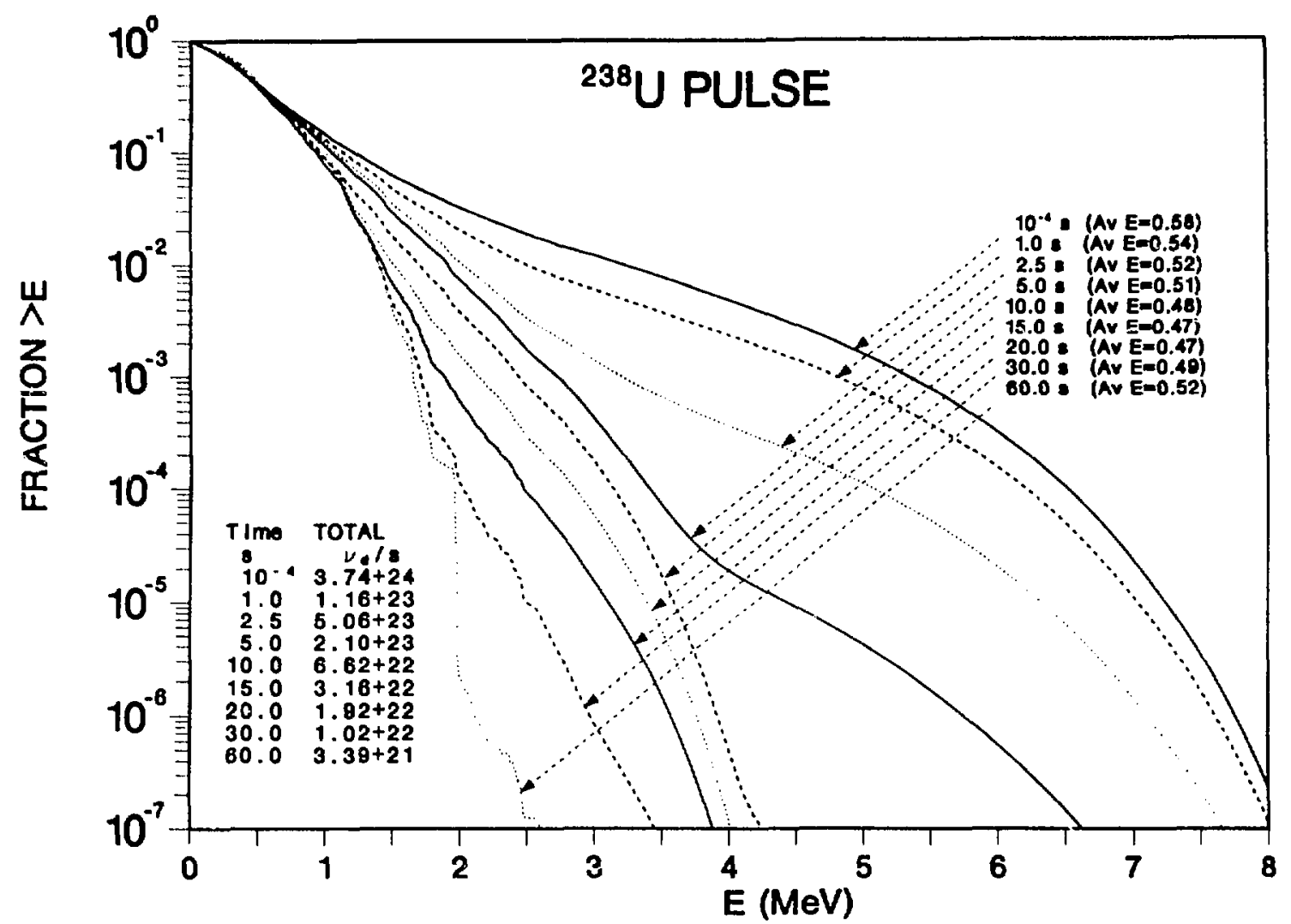

Fig. 27. ${ }^{238} \mathrm{U}$ fraction of total delayed neutrons $>\mathrm{E}$.

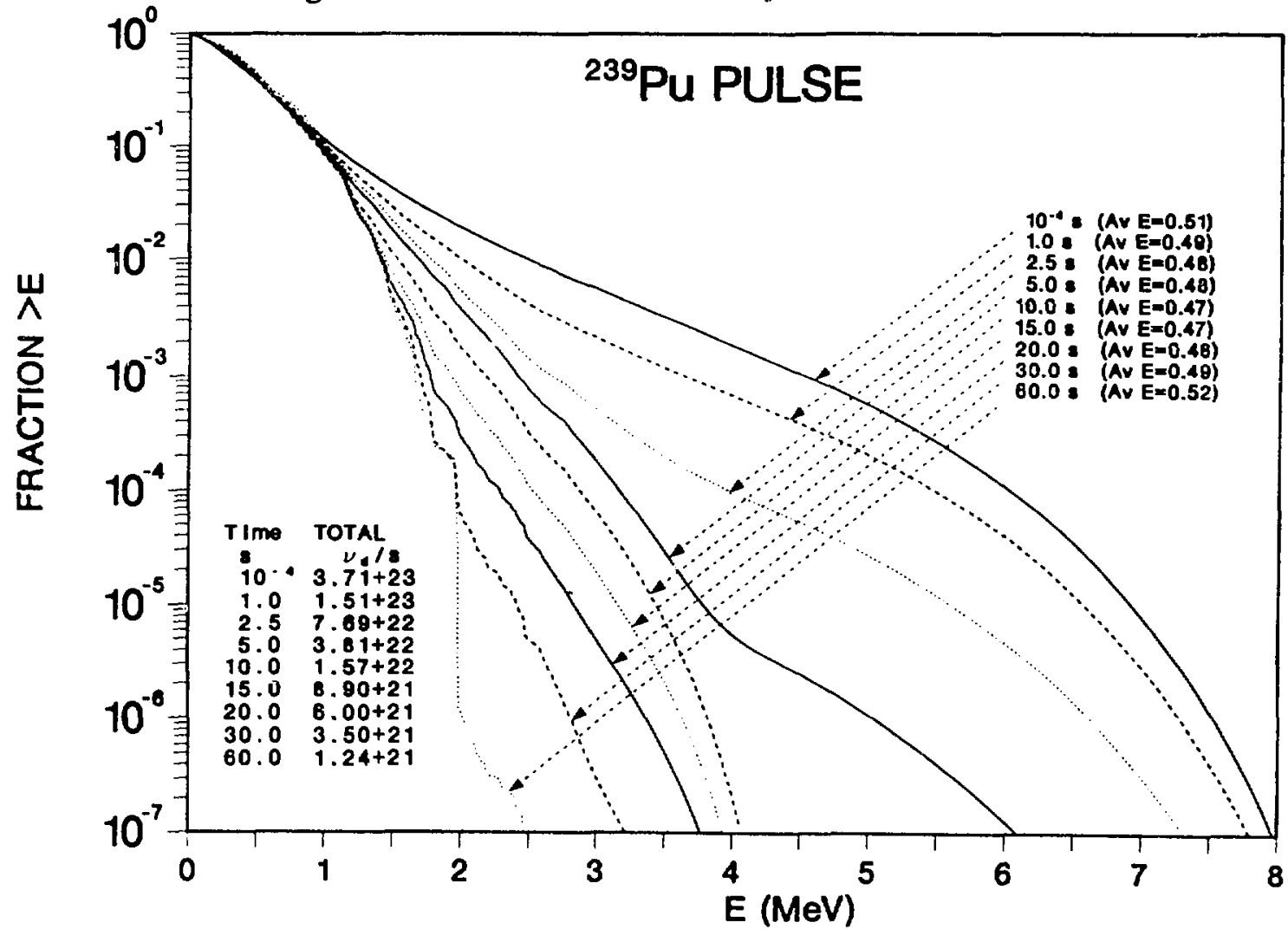

Fig. 28. ${ }^{239} \mathrm{Pu}$ fraction of total delayed neutrons $>\mathrm{E}$. 


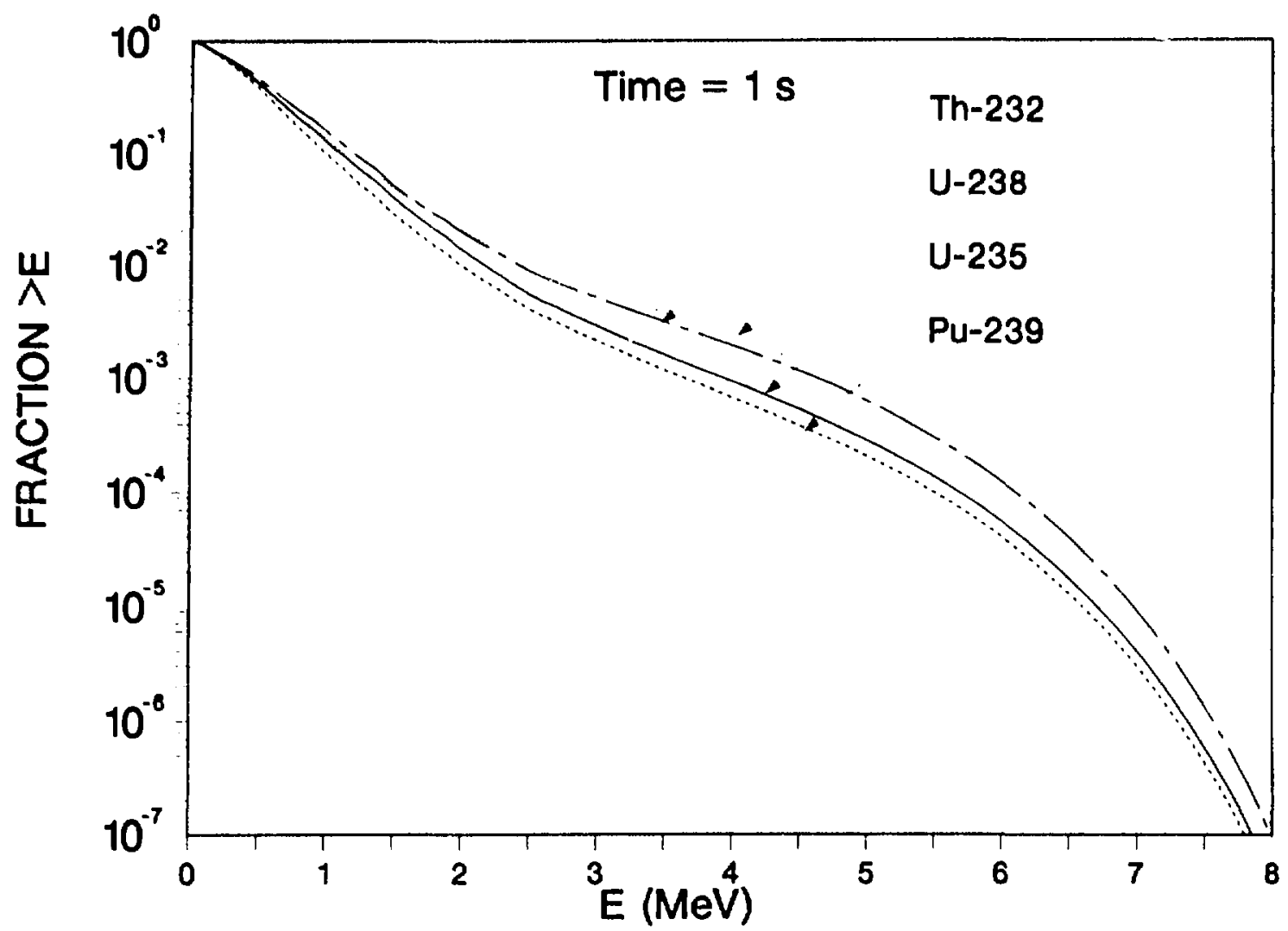

Fig. 29. Comparison of spectra fractions at $1 \mathrm{~s}$.

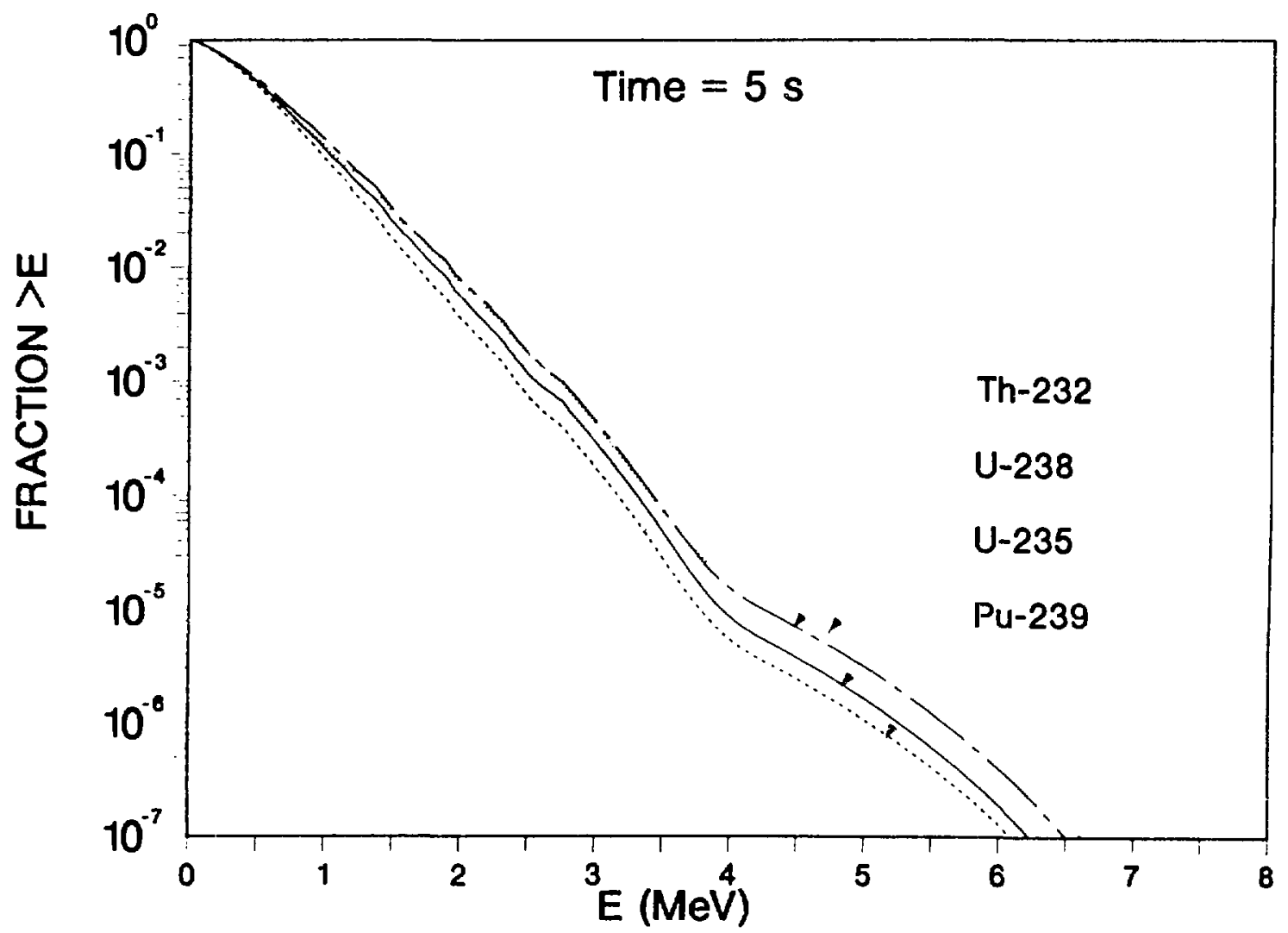

Fig. 30. Comparison of spectra fractions at $5 \mathrm{~s}$. 


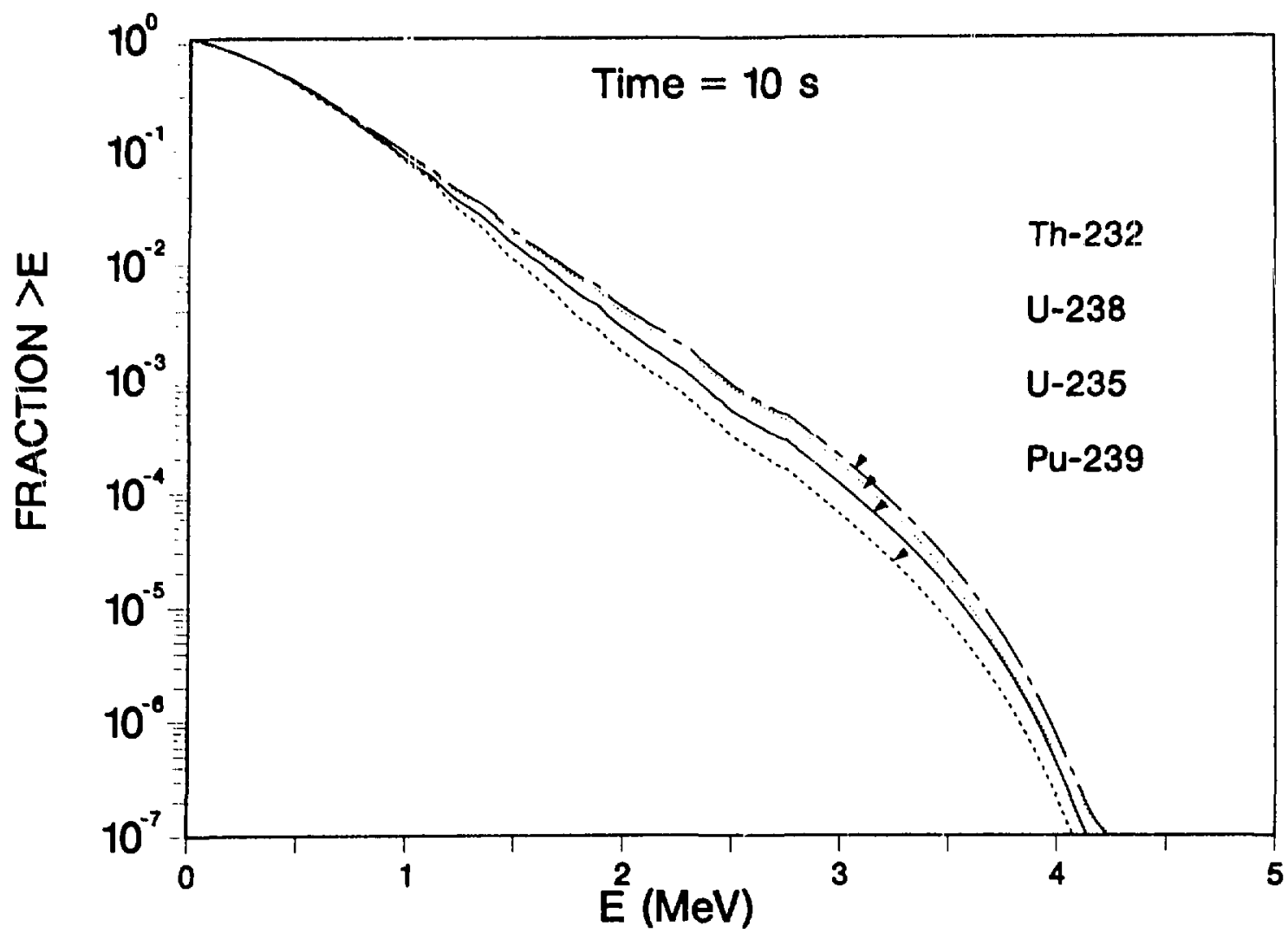

Fig. 31. Comparison of spectra fractions at $10 \mathrm{~s}$.

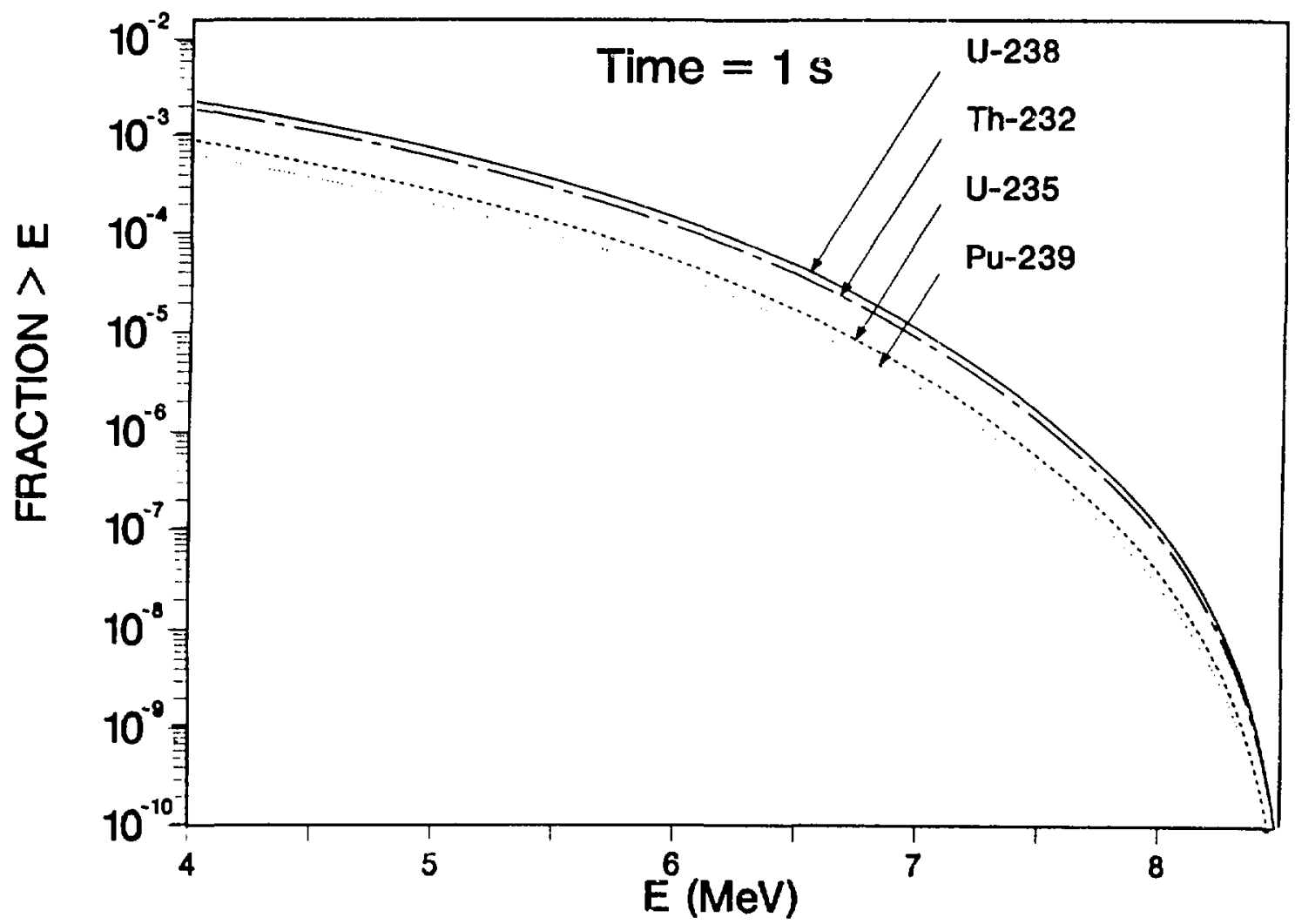

Fig. 32. Comparison: fraction of neutrons $>\mathrm{E}$ above $4 \mathrm{MeV}$ at $1 \mathrm{~s}$. 


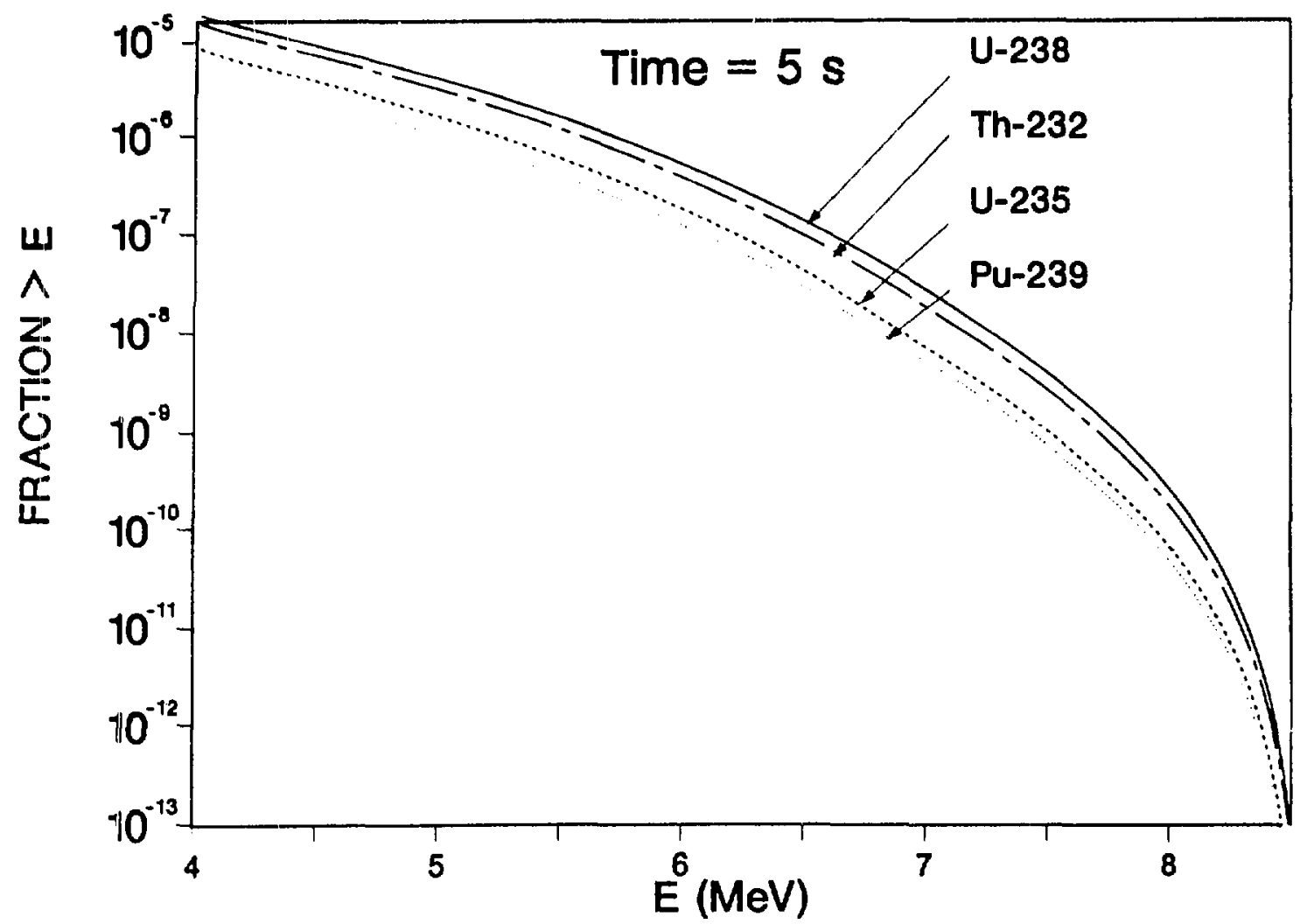

Fig. 33. Comparison: fraction of neutrons $>\mathrm{E}$ above $4 \mathrm{MeV}$ at $5 \mathrm{~s}$.

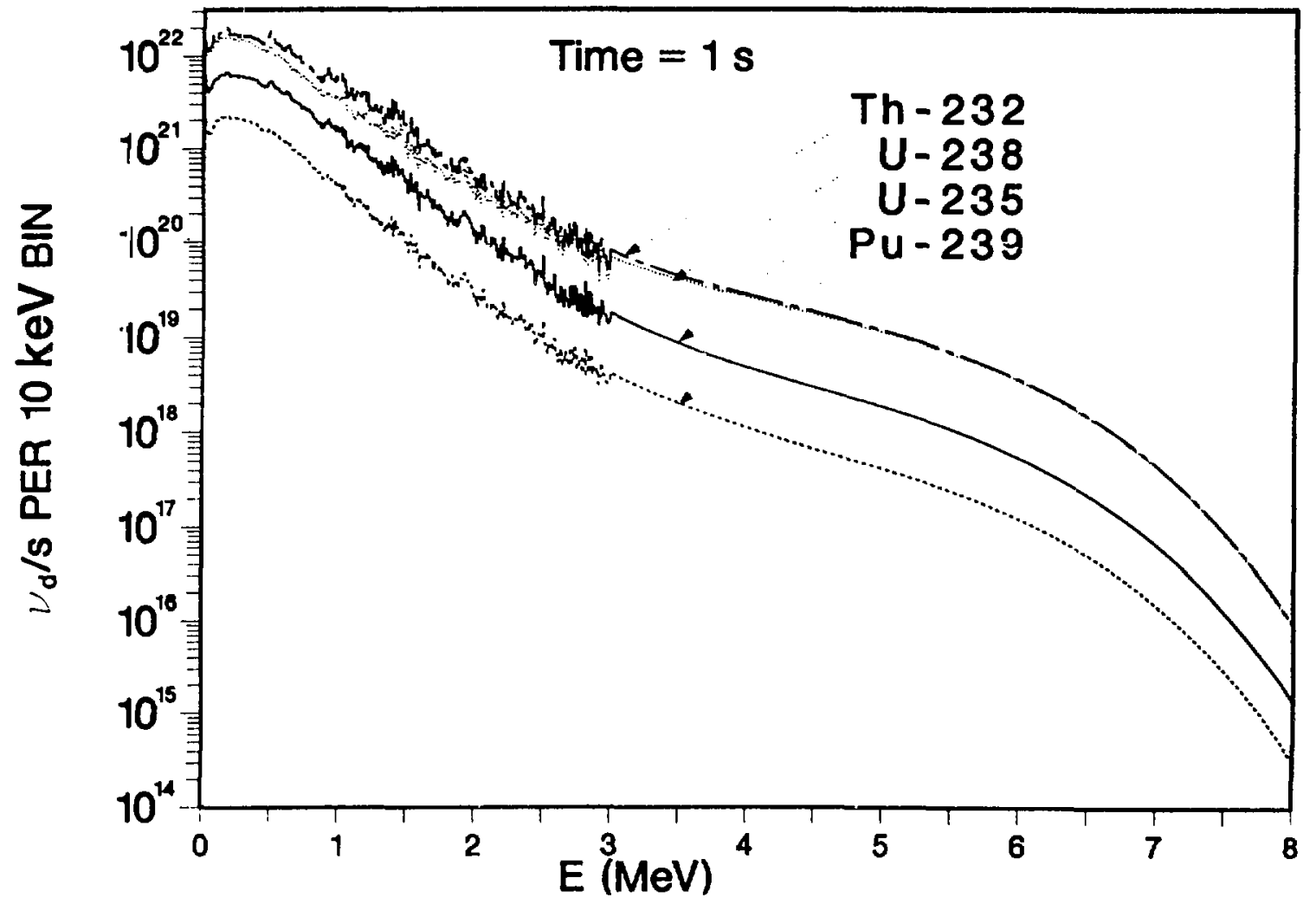

Fig. 34. $v_{d}$ spectra comparisons at $1 \mathrm{~s}$. 


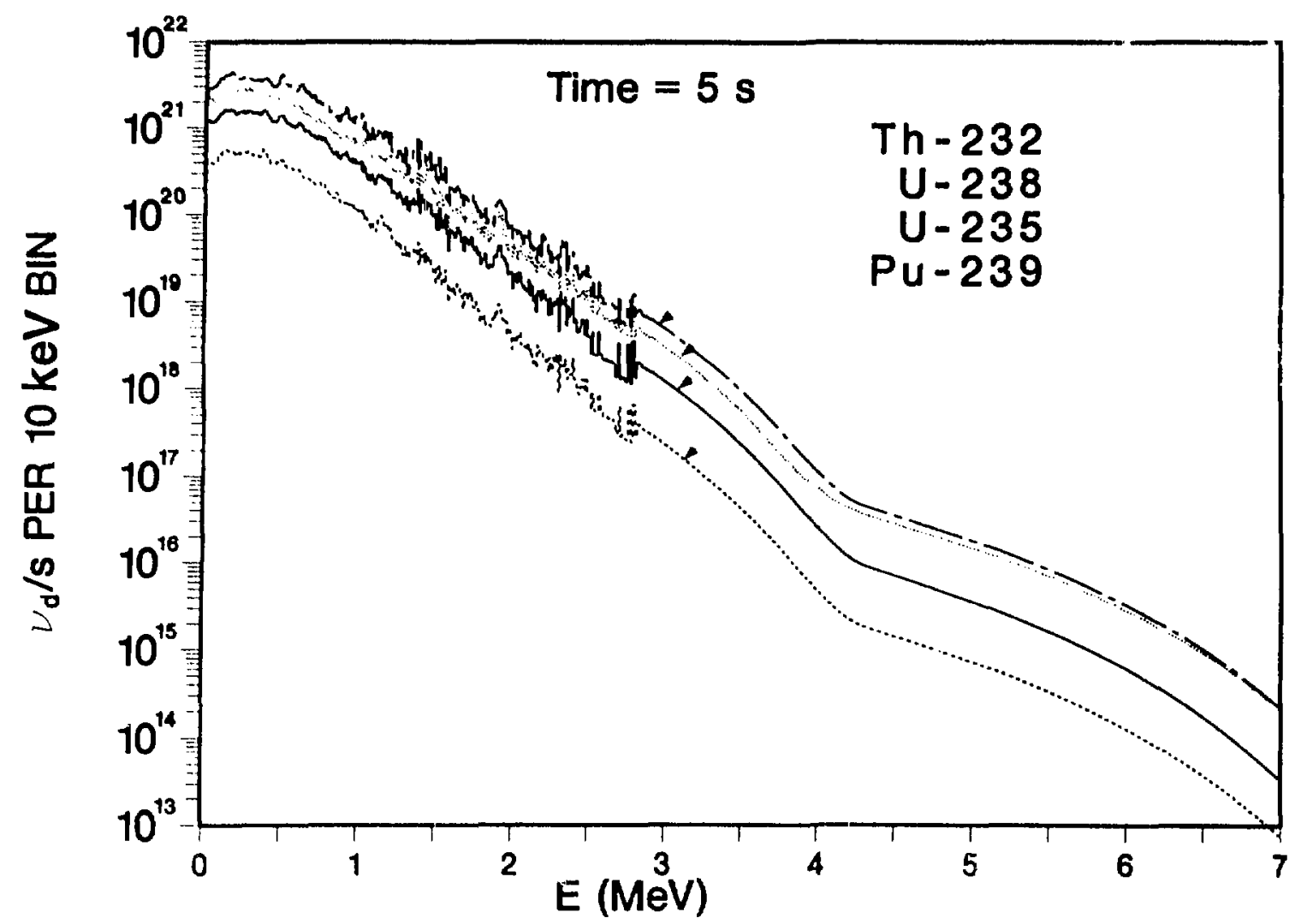

Fig. 35. $v_{\mathrm{d}}$ spectra comparisons at $5 \mathrm{~s}$. $\pi$

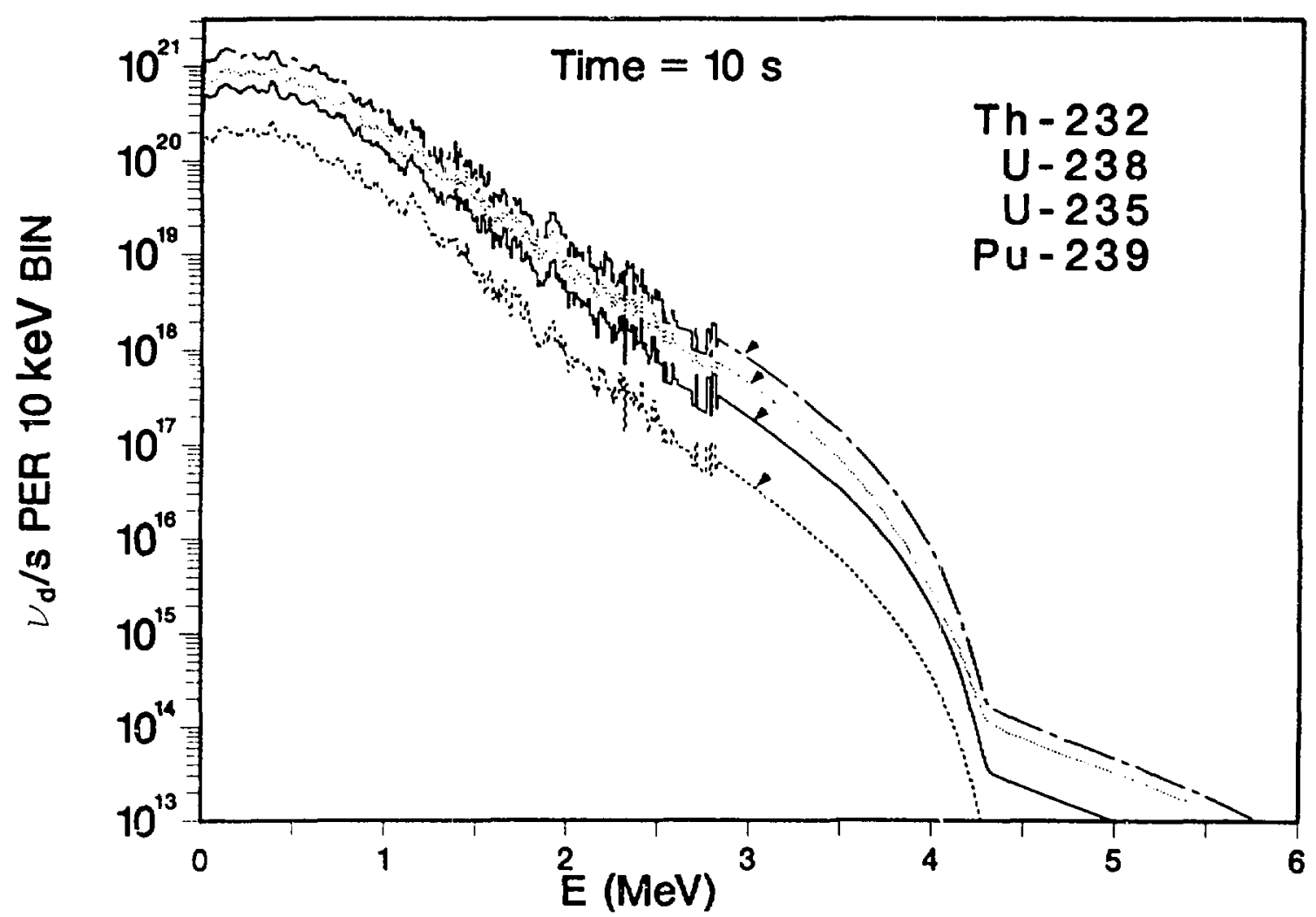

Fig. 36. $v_{d}$ spectra comparisons at $10 \mathrm{~s}$. 


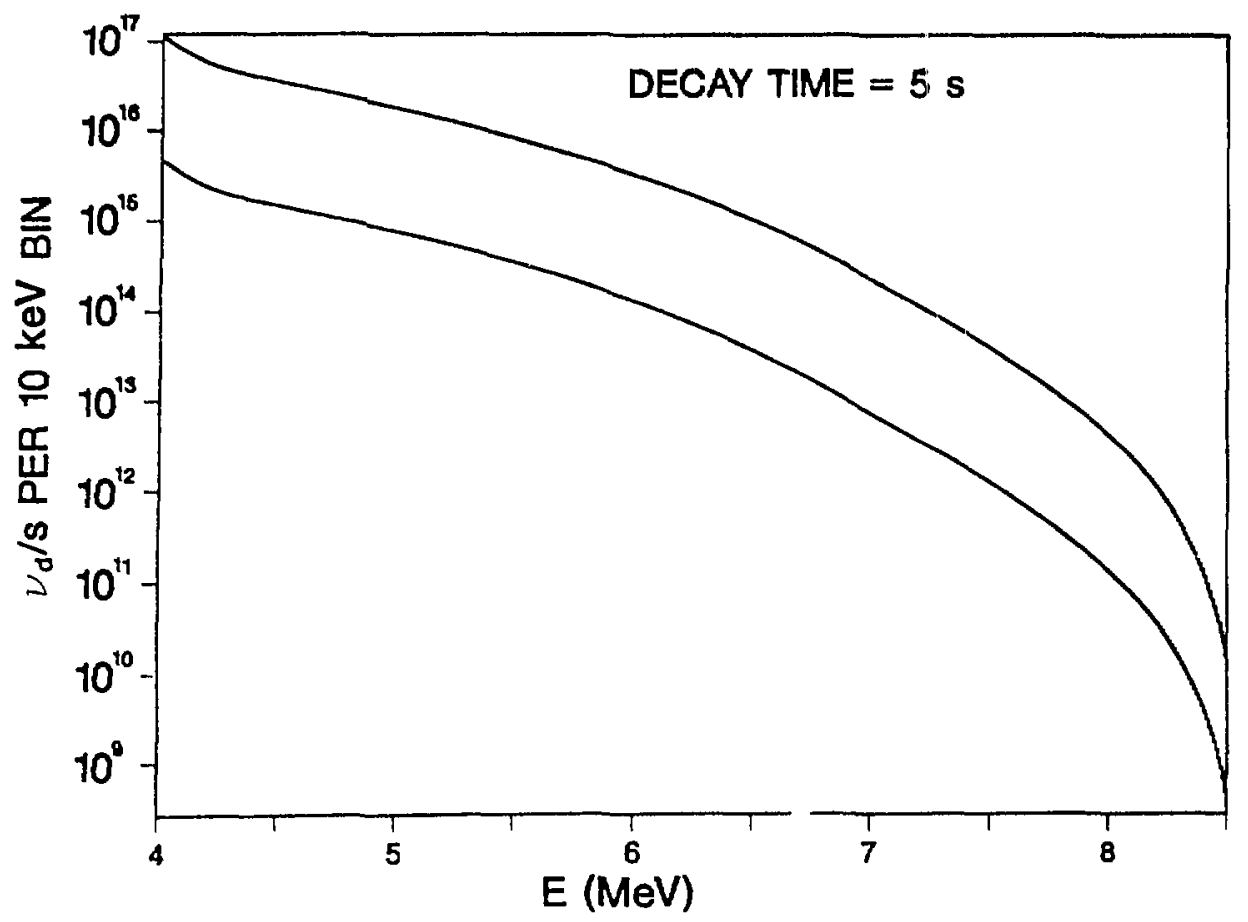

Fig. 37. Absolute delayed neutron spectra per fission for $\mathrm{E}>4 \mathrm{MeV}$.

There is a dependence of the spectra on the incident energy. Figure 38 shows this for ${ }^{235} \mathrm{U}$ at 1 and $14 \mathrm{MeV}$ at 5 -s decay, the value at $1 \mathrm{MeV}$ being significantly larger at all energies. This is generally true for all fuels.

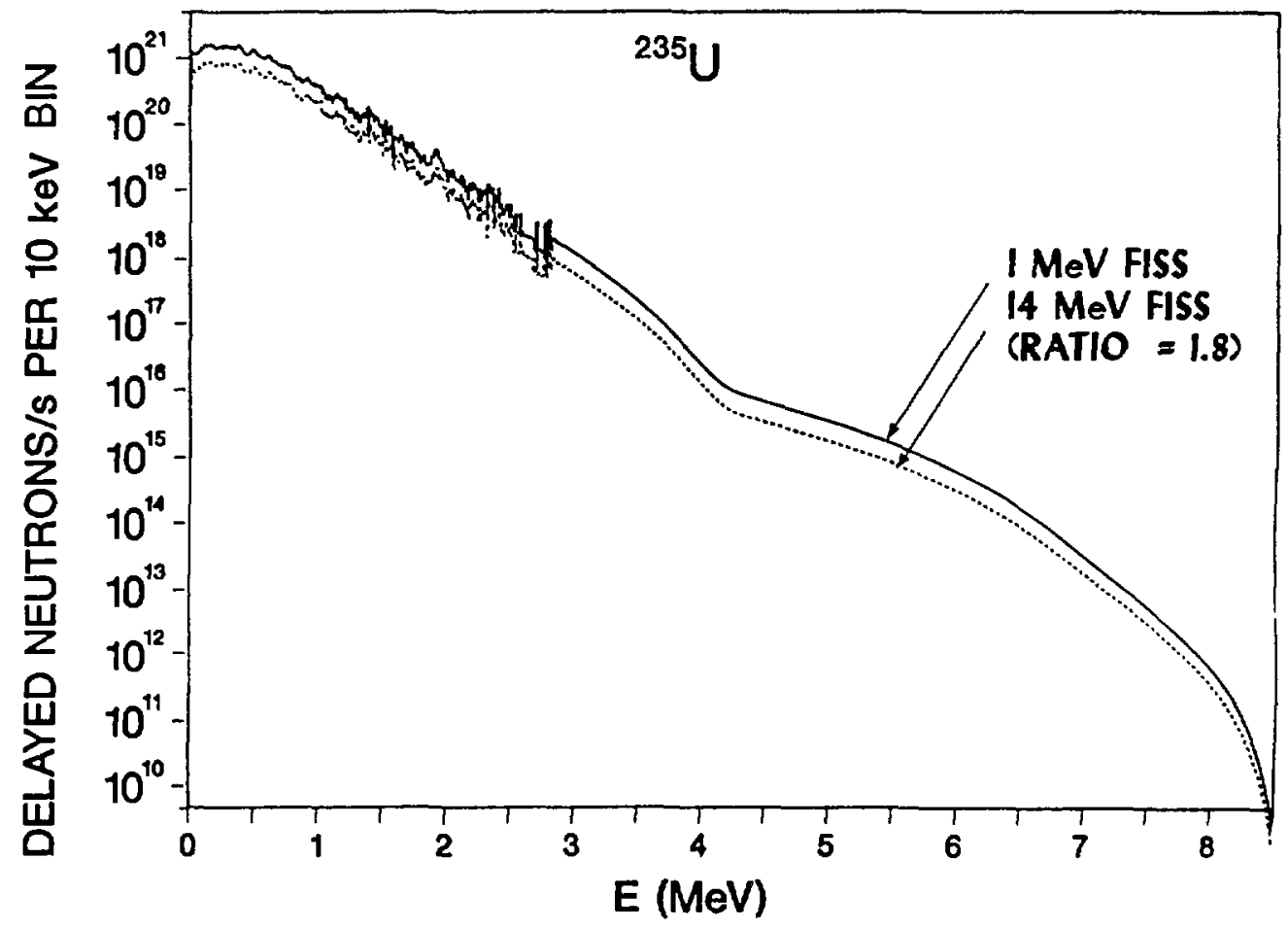

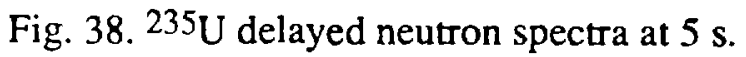


Table $\mathrm{V}$ lists the total delayed neutron rates for ${ }^{235 \mathrm{U}},{ }^{238} \mathrm{U},{ }^{239} \mathrm{Pu}$, and ${ }^{232} \mathrm{Th}$ at 39 times out to 5 minutes of decay. Tables VI-LX show fractional values of the totals at 8 cooling times remaining above each $1 / 2-\mathrm{MeV}$ energy.

TABLE $V$

TOTAL DELAYED NEUTRON RATE vs COOLING TIME

$\begin{array}{rcccc}\text { time } & u-235 & u-238 & p u-239 & t h-232 \\ 0.0 & 1.28 e+24 & 3.73 e+24 & 3.70 e+23 & 4.09 e+24 \\ 0.1 & 1.10 e+24 & 3.12 e+24 & 3.25 e+23 & 3.51 e+24 \\ 0.2 & 9.67 e+23 & 2.67 e+24 & 2.89 e+23 & 3.06 e+24 \\ 0.3 & 8.60 e+23 & 2.31 e+24 & 2.59 e+23 & 2.71 e+24 \\ 0.4 & 7.74 e+23 & 2.04 e+24 & 2.36 e+23 & 2.42 e+24 \\ 0.5 & 7.04 e+23 & 1.82 e+24 & 2.16 e+23 & 2.20 e+24 \\ 1.0 & 4.88 e+23 & 1.16 e+24 & 1.51 e+23 & 1.48 e+24 \\ 1.5 & 3.74 e+23 & 8.35 e+23 & 1.16 e+23 & 1.11 e+24 \\ 2.0 & 3.01 e+23 & 6.38 e+23 & 9.29 e+22 & 8.83 e+23 \\ 2.5 & 2.50 e+23 & 5.06 e+23 & 7.69 e+22 & 7.21 e+23 \\ 3.0 & 2.11 e+23 & 4.12 e+23 & 6.50 e+22 & 6.01 e+23 \\ 3.5 & 1.81 e+23 & 3.41 e+23 & 5.59 e+22 & 5.08 e+23 \\ 4.0 & 1.56 e+23 & 2.87 e+23 & 4.87 e+22 & 4.34 e+23 \\ 4.5 & 1.37 e+23 & 2.44 e+23 & 4.29 e+22 & 3.74 e+23 \\ 5.0 & 1.21 e+23 & 2.10 e+23 & 3.81 e+22 & 3.24 e+23 \\ 6.0 & 9.54 e+22 & 1.59 e+23 & 3.07 e+22 & 2.49 e+23 \\ 7.0 & 7.70 e+22 & 1.24 e+23 & 2.53 e+22 & 1.95 e+23 \\ 8.0 & 6.33 e+22 & 9.86 e+22 & 2.12 e+22 & 1.57 e+23 \\ 9.0 & 5.29 e+22 & 8.01 e+22 & 1.81 e+22 & 1.28 e+23 \\ 10.0 & 4.49 e+22 & 6.62 e+22 & 1.57 e+22 & 1.06 e+23 \\ 15.0 & 2.35 e+22 & 3.16 e+22 & 8.90 e+21 & 5.10 e+22 \\ 20.0 & 1.51 e+22 & 1.92 e+22 & 6.00 e+21 & 3.15 e+22 \\ 25.0 & 1.09 e+22 & 1.35 e+22 & 4.46 e+21 & 2.22 e+22 \\ 30.0 & 8.36 e+21 & 1.02 e+22 & 3.50 e+21 & 1.69 e+22 \\ 35.0 & 6.71 e+21 & 8.11 e+21 & 2.84 e+21 & 1.34 e+22 \\ 40.0 & 5.52 e+21 & 6.63 e+21 & 2.36 e+21 & 1.10 e+22 \\ 45.0 & 4.62 e+21 & 5.52 e+21 & 1.99 e+21 & 9.17 e+21 \\ 50.0 & 3.91 e+21 & 4.65 e+21 & 1.69 e+21 & 7.74 e+21 \\ 55.0 & 3.33 e+21 & 3.96 e+21 & 1.45 e+21 & 6.59 e+21 \\ 60.0 & 2.85 e+21 & 3.39 e+21 & 1.24 e+21 & 5.65 e+21 \\ 70.0 & 2.12 e+21 & 2.51 e+21 & 9.31 e+20 & 4.22 e+21 \\ 80.0 & 1.60 e+21 & 1.88 e+21 & 7.05 e+20 & 3.21 e+21 \\ 90.0 & 1.22 e+21 & 1.42 e+21 & 5.38 e+20 & 2.47+21 \\ 100.0 & 9.38 e+20 & 1.08 e+21 & 4.13 e+20 & 1.93 e+21 \\ 110.0 & 7.29 e+20 & 8.29 e+20 & 3.20 e+20 & 1.53 e+21 \\ 120.0 & 5.71 e+20 & 6.40 e+20 & 2.49 e+20 & 1.22 e+21 \\ 180.0 & 1.59 e+20 & 1.55 e+20 & 6.52 e+19 & 3.95 e+20 \\ 240.0 & 5.74 e+19 & 4.86 e+19 & 2.18 e+19 & 1.59 e+20 \\ 300.0 & 2.40 e+19 & 1.86 e+19 & 8.80 e+18 & 7.08 e+19\end{array}$


TABLE VI

$235 \mathrm{U}$

FRACTION OF DELAYED NEUTRONS ABOVE ENERGIES IN 1/2 MeV INCREMENTS

\begin{tabular}{|c|c|c|c|c|c|c|c|c|}
\hline$E$ & $\mathrm{Cs}$ & $1 s$ & $2.5 \mathrm{~s}$ & 53 & $10 \mathrm{~s}$ & $15 \mathrm{~s}$ & $30 \mathrm{~s}$ & $60 \mathrm{~s}$ \\
\hline 0.5 & $4.1-01$ & $4.1-01$ & $4.1-01$ & $4.1-01$ & $3.8-01$ & $3.6-01$ & $3.5-01$ & $3.7-01$ \\
\hline 1.0 & $1.3-01$ & $1.2-01$ & $1.2-01$ & $1.0-01$ & $8.1-02$ & $7.0-02$ & $7.5-02$ & $8.5-02$ \\
\hline 1.5 & $5.1-02$ & $3.9-02$ & $3.0-02$ & $2.4-02$ & $1.5-02$ & $8.8-03$ & $4.1-03$ & $3.4-03$ \\
\hline 2.0 & $2.3-02$ & $1.4-02$ & $7.8-03$ & $5.5-03$ & $2.7-03$ & $1.2-03$ & $1.1-04$ & $2.3-06$ \\
\hline 2.5 & $1.2-02$ & $5.4-03$ & $2.0-03$ & $1.1-03$ & $5.1-04$ & $1.8-04$ & $8.8-06$ & $1.3-07$ \\
\hline 3.0 & $6.8-03$ & $2.9-03$ & $7.5-04$ & $3.0 .-04$ & $1.2-04$ & $3.6-05$ & $5.7-07$ & $7.9-10$ \\
\hline 3.5 & $4.0-03$ & $1.6-03$ & $2.8-04$ & $4.8-05$ & $1.4-05$ & $4.2-06$ & $5.4-08$ & $4 \cdot 1-12$ \\
\hline 4.0 & $2.3-03$ & $9.2-04$ & $1.4-04$ & $8.7-06$ & $3.9-07$ & $1.0-07$ & $1.3-09$ & $4.1-14$ \\
\hline 4.5 & $1.3-03$ & $5.3-04$ & $7.4-05$ & $3.8-06$ & $2.8-08$ & $2.8-10$ & $\sim 0$ & $\sim 0$ \\
\hline 5.0 & $7.1-04$ & $2.8-04$ & $3.8-05$ & $1.6-06$ & $1.1-08$ & $9.4-11$ & $\sim 0$ & $\sim 0$ \\
\hline 5.5 & $3.4-04$ & $1.3-04$ & $1.7-05$ & $6.2-07$ & $3.5-09$ & $2.8-11$ & $\sim 0$ & $\sim 0$ \\
\hline 6.0 & $1.4-04$ & $5.4-05$ & $6.4-06$ & $1.9-07$ & $8 \cdot 3-10$ & $6.4-12$ & $\sim 0$ & $\sim 0$ \\
\hline 6.5 & $4.4-05$ & $1.7-05$ & $1.9-06$ & $4.3-08$ & $1.1-10$ & $7.7-13$ & $\sim 0$ & -0 \\
\hline 7.0 & $1.0-05$ & $3.9-06$ & $4.2-07$ & $7.3-09$ & $2.8-12$ & $\sim 0$ & $\sim 0$ & $\sim 0$ \\
\hline 7.5 & $1.5-06$ & $5.6-07$ & $6.1-08$ & $1.0-09$ & $4.8-14$ & $\sim 0$ & -0 & -0 \\
\hline 8.0 & $9.7-08$ & $3.7-08$ & $4.0-09$ & $6.8-11$ & $\sim 0$ & -0 & $\sim 0$ & $\sim 0$ \\
\hline 8.5 & 4. $2-11$ & 8. $7-12$ & $8.5-13$ & $4.4-15$ & $\sim 0$ & $\sim 0$ & $\sim 0$ & $\sim 0$ \\
\hline 9.0 & $3.7-12$ & $\sim 0$ & $\sim 0$ & -0 & $\sim 0$ & $\sim 0$ & $\sim 0$ & -0 \\
\hline 9.5 & $6 \cdot 3-13$ & $\sim 0$ & $\sim 0$ & -0 & $\sim 0$ & -0 & $\sim 0$ & $\sim 0$ \\
\hline
\end{tabular}

TABLE VII

$238 \mathrm{U}$

FRACTION OF DELAYED NEUTRONS ABOVE ENERGIES IN 1/2-MeV INCREMENTS

$\begin{array}{ccccccccc}E & 0 \mathrm{~s} & 1 \mathrm{~s} & 2.5 \mathrm{~s} & 5 \mathrm{~s} & 10 \mathrm{~s} & 15 \mathrm{~s} & 30 \mathrm{~s} & 60 \mathrm{~s} \\ 0.5 & 4.0-01 & 3.9-01 & 4.0-01 & 4.0-01 & 3.8-01 & 3.7-01 & 3.9-01 & 4.2-01 \\ 1.0 & 1.5-01 & 1.3-01 & 1.2-01 & 1.1-01 & 8.9-02 & 7.7-02 & 8.6-02 & 9.9-02 \\ 1.5 & 6.3-02 & 4.7-02 & 3.4-02 & 2.9-02 & 1.8-02 & 1.0-02 & 4.5-03 & 3.6-03 \\ 2.0 & 3.2-02 & 2.0-02 & 1.0-02 & 7.3-03 & 3.8-03 & 1.5-03 & 1.1-04 & 2.1-06 \\ 2.5 & 1.9-02 & 9.9-03 & 3.3-03 & 1.7-03 & 8.1-04 & 2.9-04 & 1.0-05 & 1.2-07 \\ 3.0 & 1.2-02 & 6.0-03 & 1.4-03 & 4.2-04 & 1.7-04 & 5.7-05 & 8.4-07 & 7.9-10 \\ 3.5 & 7.7-03 & 3.7-03 & 6.5-04 & 7.1-05 & 1.7-05 & 5.5-06 & 7.3-08 & 5.2-12 \\ 4.0 & 4.8-03 & 2.3-03 & 3.6-04 & 1.9-05 & 4.7-07 & 1.1-07 & 1.4-09 & 6.4-14 \\ 4.5 & 2.8-03 & 1.4-03 & 2.1-04 & 9.0-06 & 6.2-08 & 6.0-10 & \sim 0 & \sim 0 \\ 5.0 & 1.6-03 & 7.6-04 & 1.1-04 & 4.1-06 & 2.4-08 & 2.0-10 & \sim 0 & \sim 0 \\ 5.5 & 7.5-04 & 3.7-04 & 5.1-05 & 1.6-06 & 8.0-09 & 6.3-11 & \sim 0 & \sim 0 \\ 6.0 & 3.1-04 & 1.5-04 & 2.0-05 & 5.5-07 & 1.9-09 & 1.5-11 & \sim 0 & \sim 0 \\ 6.5 & 1.0-04 & 4.8-05 & 6.2-06 & 1.4-07 & 2.6-10 & 1.9-12 & \sim 0 & \sim 0 \\ 7.0 & 2.3-05 & 1.1-05 & 1.4-06 & 2.8-08 & 9.5-12 & 1.7-14 & \sim 0 & \sim 0 \\ 7.5 & 3.3-06 & 1.6-06 & 2.0-07 & 4.0-09 & 6.8-13 & \sim 0 & \sim 0 & \sim 0 \\ 8.0 & 2.2-07 & 1.1-07 & 1.3-08 & 2.6-10 & \sim 0 & \sim 0 & \sim 0 & \sim 0 \\ 8.5 & 1.3-10 & 2.4-11 & 2.9-12 & 5.1-14 & \sim 0 & \sim 0 & \sim 0 & \sim 0 \\ 9.0 & 1.6-11 & \sim 0 & \sim 0 & \sim 0 & \sim 0 & \sim 0 & \sim 0 & \sim 0 \\ 9.5 & 3.4-12 & \sim 0 & \sim 0 & \sim 0 & \sim 0 & \sim 0 & \sim 0 & \sim 0\end{array}$


TABLE VIII

232Th

FRACTION OF DELAYED NEUTRONS ABOVE ENERGIES IN 1/2-MeV INCREMENTS

\begin{tabular}{|c|c|c|c|c|c|c|c|c|}
\hline$E$ & $0 \mathrm{~s}$ & $1 \mathfrak{s}$ & $2.5 \mathrm{~s}$ & $5 s$ & $10 \mathrm{~s}$ & $15 \mathrm{~s}$ & $30 \mathrm{~s}$ & $60 \mathrm{~s}$ \\
\hline 0.5 & $4.6-01$ & $4.5-01$ & $4.5-01$ & $4.4-01$ & $3.9-01$ & $3.5-01$ & $3.0-01$ & $2.9-01$ \\
\hline 1.0 & $1.7-01$ & $1.5-01$ & $1.4-01$ & $1.3-01$ & $9.1-02$ & 6.7 .02 & $5.8-02$ & $6.3-02$ \\
\hline 1.5 & $6.8-02$ & $5.0-02$ & $3.7-02$ & $3.1-02$ & $1.9-02$ & $1.1-02$ & $3.9-03$ & $3.1-03$ \\
\hline 2.0 & $3.2-02$ & $1.9-02$ & $1.1-02$ & $7.8-03$ & $4.2-03$ & $1.8-03$ & 1. $4-04$ & $2.9-06$ \\
\hline 2.5 & $1.8-02$ & $8.8-03$ & $3.1-03$ & $1.8-03$ & $8.7-04$ & $3.3-04$ & $1.2-05$ & $1.7-07$ \\
\hline 3.0 & $1.1-02$ & $5.1-03$ & $1.2-03$ & $4.5-04$ & $2.0-04$ & $7.0-05$ & $1.1-06$ & $1.0-09$ \\
\hline 3.5 & $7.2-03$ & $3.1-03$ & $5.3-04$ & $7.5-05$ & $2.4-05$ & $8.1-06$ & $1.2-07$ & $1.1-11$ \\
\hline 4.0 & $4.5-03$ & $1.9-03$ & $2.8-04$ & $1.6-05$ & $6.8-07$ & $1.9-07$ & $2.8-09$ & $2.0-13$ \\
\hline 4.5 & $2.7-03$ & $1.1-03$ & $1.6-04$ & $7.0-06$ & $5.6-08$ & $7.3-10$ & -0 & $\sim 0$ \\
\hline 5.0 & $1.5-03$ & $6.2-04$ & $8.2-05$ & $3.2-06$ & $2.1-08$ & $2.3-10$ & -0 & $\sim 0$ \\
\hline 5.5 & $7.1-04$ & $3.0-04$ & $3.8-05$ & $1.2-06$ & $6.8-09$ & $6.8-11$ & -0 & $\sim 0$ \\
\hline 6.0 & $2.9-04$ & $1.2-04$ & $1.5-05$ & $4.0-07$ & $1.6-09$ & $1 \cdot 6-11$ & $\sim 0$ & $\sim 0$ \\
\hline 6.5 & $9.4-05$ & $3.9-05$ & $4.6-06$ & $9.9-08$ & $2.2-10$ & $2 \cdot 1-12$ & $\sim 0$ & $\sim 0$ \\
\hline 7.0 & $2.2-05$ & $8.9-06$ & $1.0-06$ & $1.9-08$ & $7.2-12$ & $2.6-14$ & $\sim 0$ & $\sim 0$ \\
\hline 7.5 & $3.1-06$ & $1.3-06$ & $1.5-07$ & $2.7-09$ & $3.7-13$ & $\sim 0$ & $\sim 0$ & -0 \\
\hline 8.0 & $2.1-07$ & $8 \cdot 5-08$ & $9.8-09$ & $1.8-10$ & $\sim 0$ & -0 & $\sim 0$ & $\sim 0$ \\
\hline 8.5 & $2.2-10$ & $2 \cdot 4-11$ & $2.4-12$ & $2 \cdot 6-14$ & $\sim 0$ & $\sim 0$ & -0 & $\sim 0$ \\
\hline 9.0 & $3.9-11$ & -0 & -0 & $\sim 0$ & $\sim 0$ & -0 & $\sim 0$ & $\sim 0$ \\
\hline 9.5 & $9.0-12$ & $\sim 0$ & .0 & $\sim 0$ & $\sim 0$ & $\sim 0$ & $\sim 0$ & $\sim 0$ \\
\hline
\end{tabular}

\section{TABLE IX ${ }^{239} \mathrm{Pu}$}

\section{FRACTION OF DELAYED NEUTRONS ABOVE ENERGIES IN 1/2-MeV INCREMENTS}

$\begin{array}{ccccccccc}\text { E } & 0 \mathrm{~s} & 1 \mathrm{~s} & 2.5 \mathrm{~s} & 5 \mathrm{~s} & 10 \mathrm{~s} & 15 \mathrm{~s} & 30 \mathrm{~s} & 60 \mathrm{~s} \\ 0.5 & 3.7-01 & 3.7-01 & 3.7-01 & 3.7-01 & 3.7-01 & 3.7-01 & 4.0-01 & 4.2-01 \\ 1.0 & 1.1-01 & 9.7-02 & 9.2-02 & 8.7-02 & 7.7-02 & 7.7-02 & 9.0-02 & 1.0-01 \\ 1.5 & 4.1-02 & 2.8-02 & 2.1-02 & 1.7-02 & 1.1-02 & 7.0-03 & 4.1-03 & 3.7-03 \\ 2.0 & 1.9-02 & 9.8-03 & 5.2-03 & 3.6-03 & 1.7-03 & 6.9-04 & 5.9-05 & 1.1-06 \\ 2.5 & 9.7-03 & 4.0-03 & 1.4-03 & 7.3-04 & 3.1-04 & 1.1-04 & 4.9-06 & 6.3-08 \\ 3.0 & 5.6-03 & 2.1-03 & 5.0-04 & 1.8-04 & 6.3-05 & 1.9-05 & 3.0-07 & 4.2-10 \\ 3.5 & 3.2-03 & 1.2-03 & 2.0-04 & 2.8-05 & 7.2-06 & 2.0-06 & 2.4-08 & 1.7-12 \\ 4.0 & 1.8-03 & 6.7-04 & 9.7-05 & 5.5-06 & 2.0-07 & 4.8-08 & 5.6-10 & \sim 0 \\ 4.5 & 1.0-03 & 3.8-04 & 5.3-05 & 2.4-06 & 1.5-08 & 1.3-10 & \sim 0 & \sim 0 \\ 5.0 & 5.5-04 & 2.1-04 & 2.7-05 & 1.1-06 & 6.0-09 & 4.4-11 & \sim 0 & \sim 0 \\ 5.5 & 2.7-04 & 9.8-05 & 1.2-05 & 4.1-07 & 2.0-09 & 1.3-11 & \sim 0 & -0 \\ 6.0 & 1.1-04 & 4.0-05 & 4.7-06 & 1.3-07 & 4.7-10 & 3.0-12 & \sim 0 & \sim 0 \\ 6.5 & 3.5-05 & 1.3-05 & 1.4-06 & 3.0-08 & 6.2-11 & 3.4-13 & \sim 0 & \sim 0 \\ 7.0 & 8.0-06 & 2.9-06 & 3.1-07 & 5.3-09 & 1.6-12 & \sim 0 & \sim 0 & -0 \\ 7.5 & 1.2-06 & 4.1-07 & 4.5-08 & 7.4-10 & 2.1-14 & \sim 0 & \sim 0 & \sim 0 \\ 8.0 & 7.7-08 & 2.7-08 & 3.0-09 & 4.9-11 & \sim 0 & \sim 0 & \sim 0 & \sim 0 \\ 8.5 & 2.1-11 & 5.9-12 & 6.1-13 & \sim 0 & \sim 0 & \sim 0 & \sim 0 & \sim 0 \\ 9.0 & 5.0-13 & \sim 0 & \sim 0 & \sim 0 & \sim 0 & \sim 0 & \sim 0 & \sim 0 \\ 9.5 & \sim 0 & \sim 0 & \sim 0 & \sim 0 & \sim 0 & \sim 0 & \sim 0 & \sim 0\end{array}$


Appendix $B$ tabulates precursors with contributions greater than $0.01 \%$ at various times above $O$ and $4 \mathrm{MeV}$. The more important high-energy emitters are also identified in Fig. 4; specifically isotopes of $\mathrm{As}, \mathrm{Br}, \mathrm{I}$, and $\mathrm{Rb}$ are important at energies above $4 \mathrm{MeV}$ for decay times between I and $10 \mathrm{~s}$. Measurements of a few of these at energies $>3 \mathrm{MeV}$ could greatly improve calculations for the various fuels and provide tests for the nuclear models that must be used for most of the precursors.

The reader is reminded that measured data exist for a small fraction of the number of probable precursors and their energy range, as illustrated in Fig. 39.

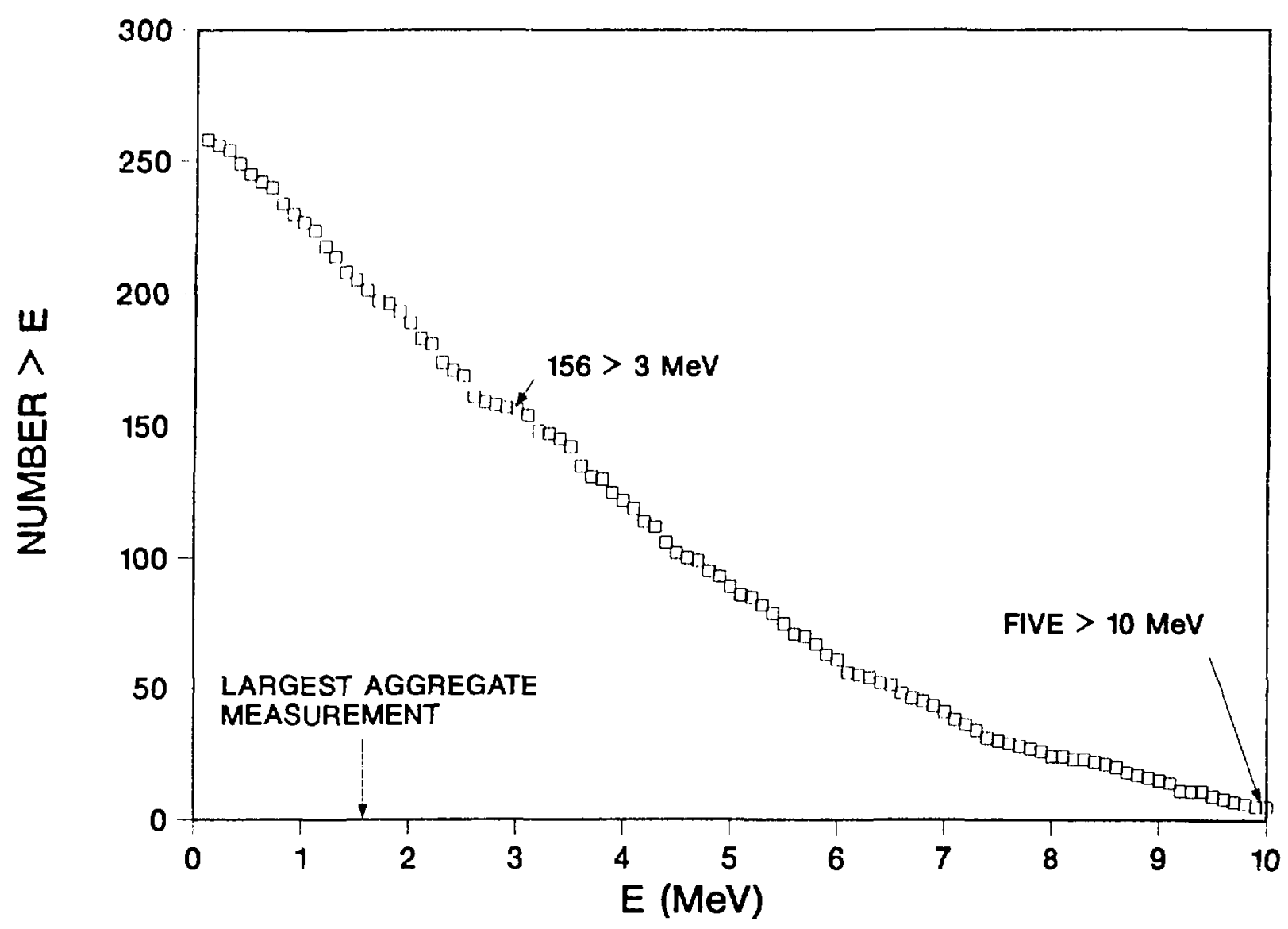

Fig. 39. Number of precursors having energies $>\mathrm{E}$.

Finally, some readers will be interested in the conventional six-time group approximations to these results. This has been made for most fuels and will be of most interest to reactor designers. Results for some fuels have been published in Refs. 26 and 27 and will be discussed in detail in the aforementioned dissertation (Ref. 15). 


\section{$v$. DELAYED $\beta$ - AND $\gamma$ RADIATION FROM FISSION PRODUCTS}

Delayed radiations are considered to be occurring later than $10^{-4} \mathrm{~s}$ after the fission pulse. The fields coming from approximately 800 different radioactive products ccupled by decay produce $\beta$ and $\gamma$ rays as well as delayed neutrons. The ensemble varies with fissioning species, fission neutron energy, and with time.

To evaluate the nuclear background following a nuclear explosion, we explicitly include all nuclides in several hundred chains that typically consist of 6 to 20 nuclides each (isotopes and isomers). For this, we need to know the initial yield of each nuclide, nuclide halflives, branching fractions per decay, and the detailed $\beta$ - and $\gamma$ energy distributions, as discussed in Secs. I and II, and in Ref. 4.

While the method of calculating the aggregate radiation fields from this plexus is exact, the data are not. Measured and evaluated data per nuclide are used if known; otherwise we necessarily resort to systematics and nuclear models. There are measured spectra for 300 of the approximately 800 radioactive products, and spectra based on systematics were constructed for the remaining, less important, unmeasured products. For three fissioning nuclides, namely, ${ }^{235} \mathrm{U},{ }^{239} \mathrm{Pu}$, and ${ }^{241} \mathrm{Pu}$ at thermal neutron fission energies, there are high quality aggregate spectra measurements to $7.5 \mathrm{MeV}$ to use in validations. Investigations based on these experiments have revealed that at least 50 of the most important individual products are missing high energy gamma transitions. The resulting aggregate calculations show a gamma energy that is too small and a spectrum that is skewed towards low energy emission. (The opposite is true for beta spectra.) The number of important products having a deficiency is too large to be corrected with a few selected measurements, so the data base must be augmented with nuclear model calculations.

We have improved aggregate spectra for ${ }^{235} \mathrm{U}$ and ${ }^{239} \mathrm{Pu}$ using the recent ORNL measurements of Refs. 10 and 11. With the exception of ${ }^{241} \mathrm{Pu}$, this cannot be done for other fuels.

By plotting the spectra as a fraction of the energy remaining above the abscissa energy, as in Sec. IV for ${ }^{\nabla_{d}}$, we can compare the temporal variations of $\beta-\gamma$, and delayed neutrons. This is done in Figs. 40-43 at four cooling times. Here one can see the relatively rapid drop in highenergy neutrons vs time compared with $\beta^{-}$and $\gamma$ energies. As noted on these plots, the average and total $\beta^{-}$and $\gamma$ energies are larger at all times than values for delayed neutrons.

New decay heat measurements are currently being made in $\operatorname{Japan}^{8,9}$ and we are in the process of including these data in our files as they become available. Figures 44-47 show comparisons of Japanese measurements of $\beta$ - and $\gamma$ decay heat for ${ }^{238} \mathrm{U}$ and ${ }^{232} \mathrm{Th}$ with our calculations using data from ENDF/B-IV and ENDF/B-V. These figures clearly illustrate the need for updating our files. We anticipate that the Japanese will soon make available new spectral measurements that would be useful in additional file improvements. Thus, considering the promise of new measurements, 
along with development and application of nuclear model codes, we expect to be able to greatly improve our data base, and, consequently, improve our predictive capabilities during the next year.

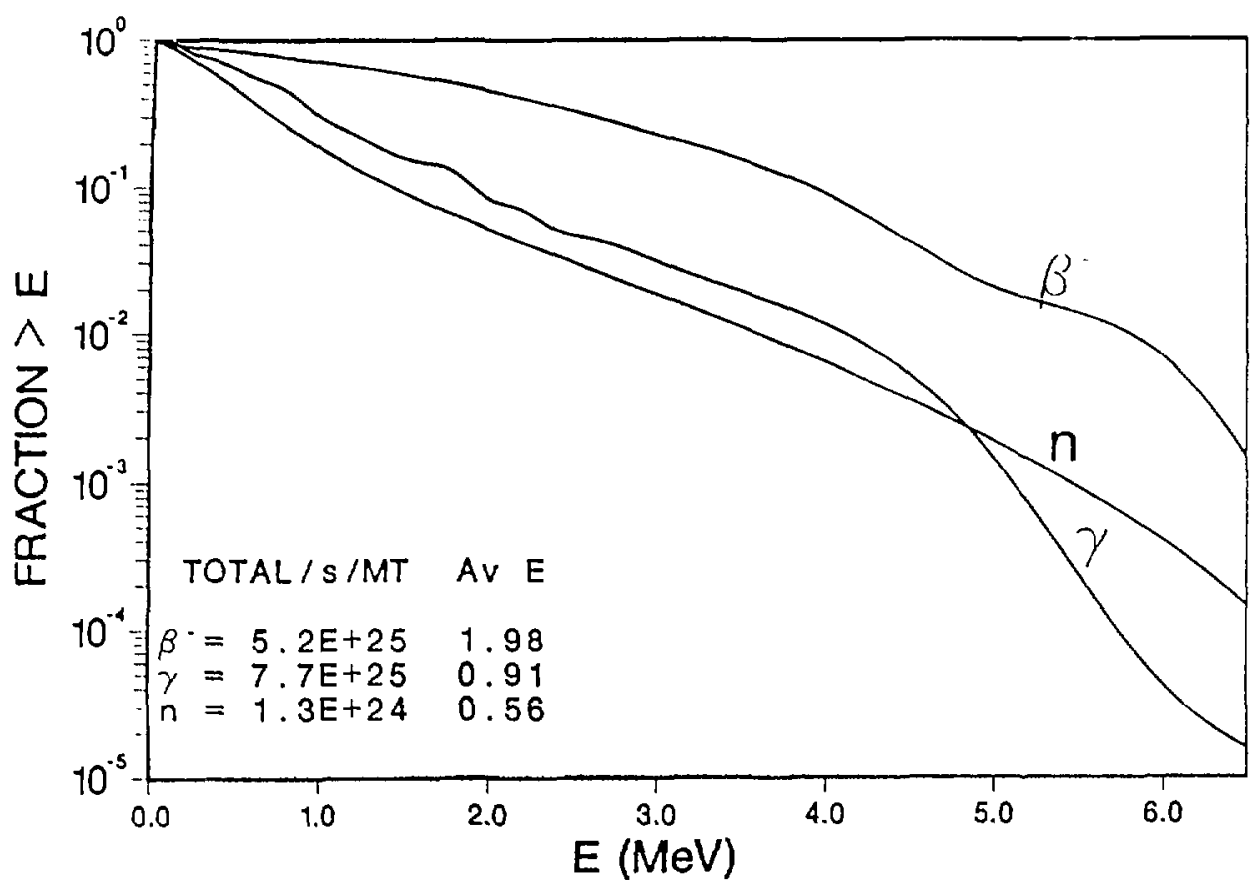

Fig. 40. ${ }^{235 \mathrm{U}}$ Fission: Background at $\mathrm{T}=10^{-4} \mathrm{~s}$.

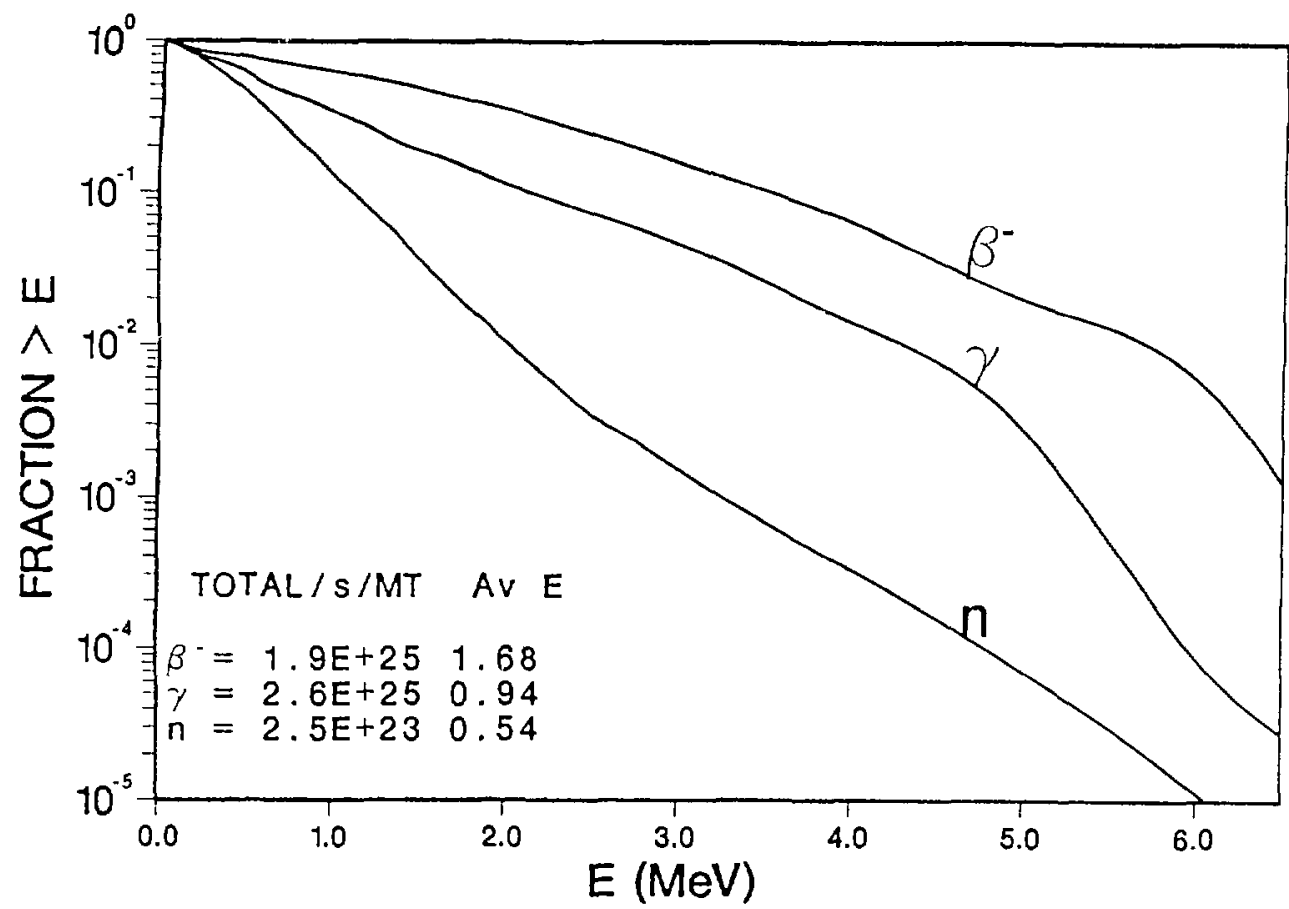

Fig. 41. ${ }^{235} \mathrm{U}$ Fission: Background at $\mathrm{T}=2.5 \mathrm{~s}$. 


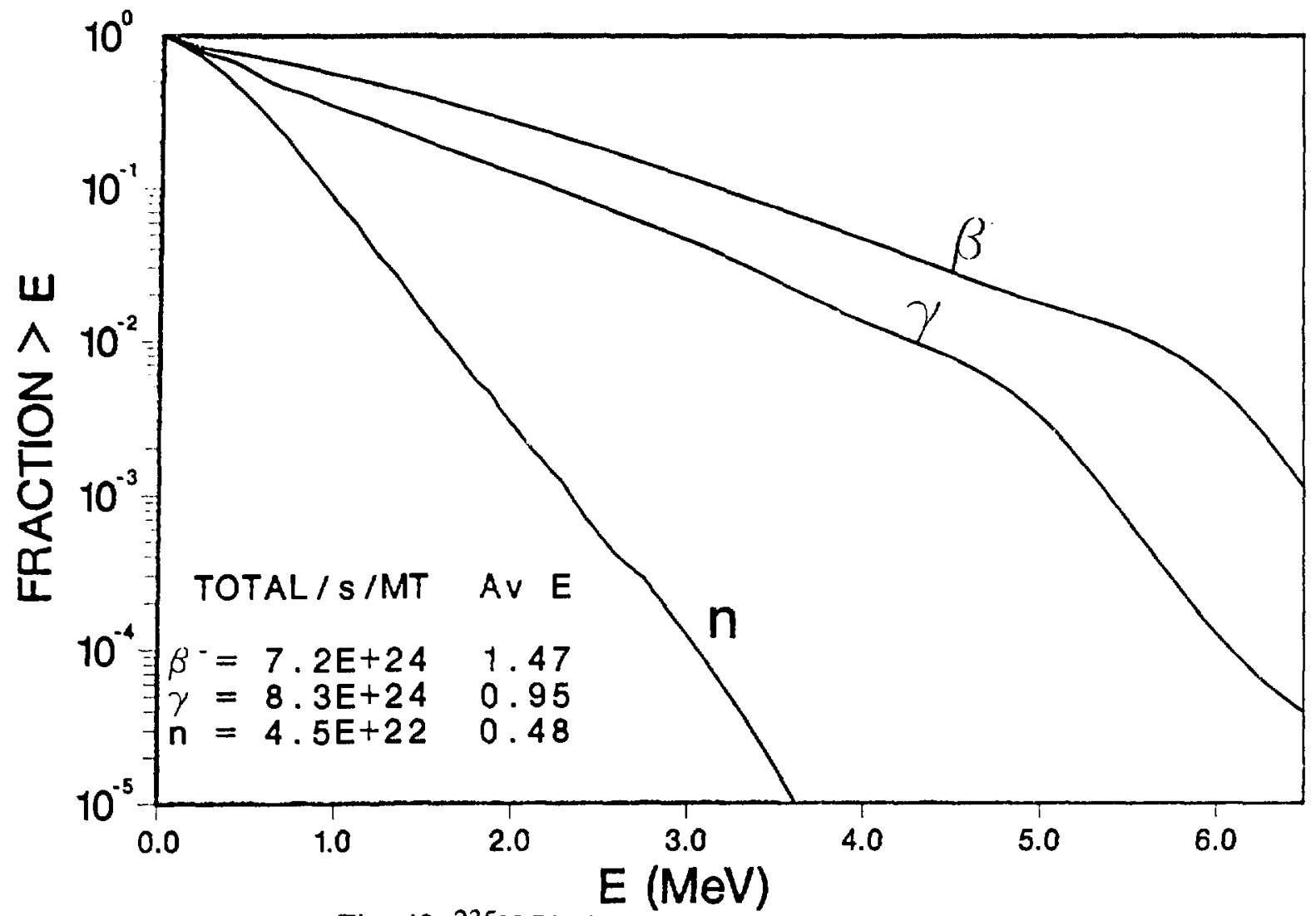

Fig. 42. ${ }^{235} \mathrm{U}$ Fission: Background at $\mathrm{T}=10 \mathrm{~s}$.

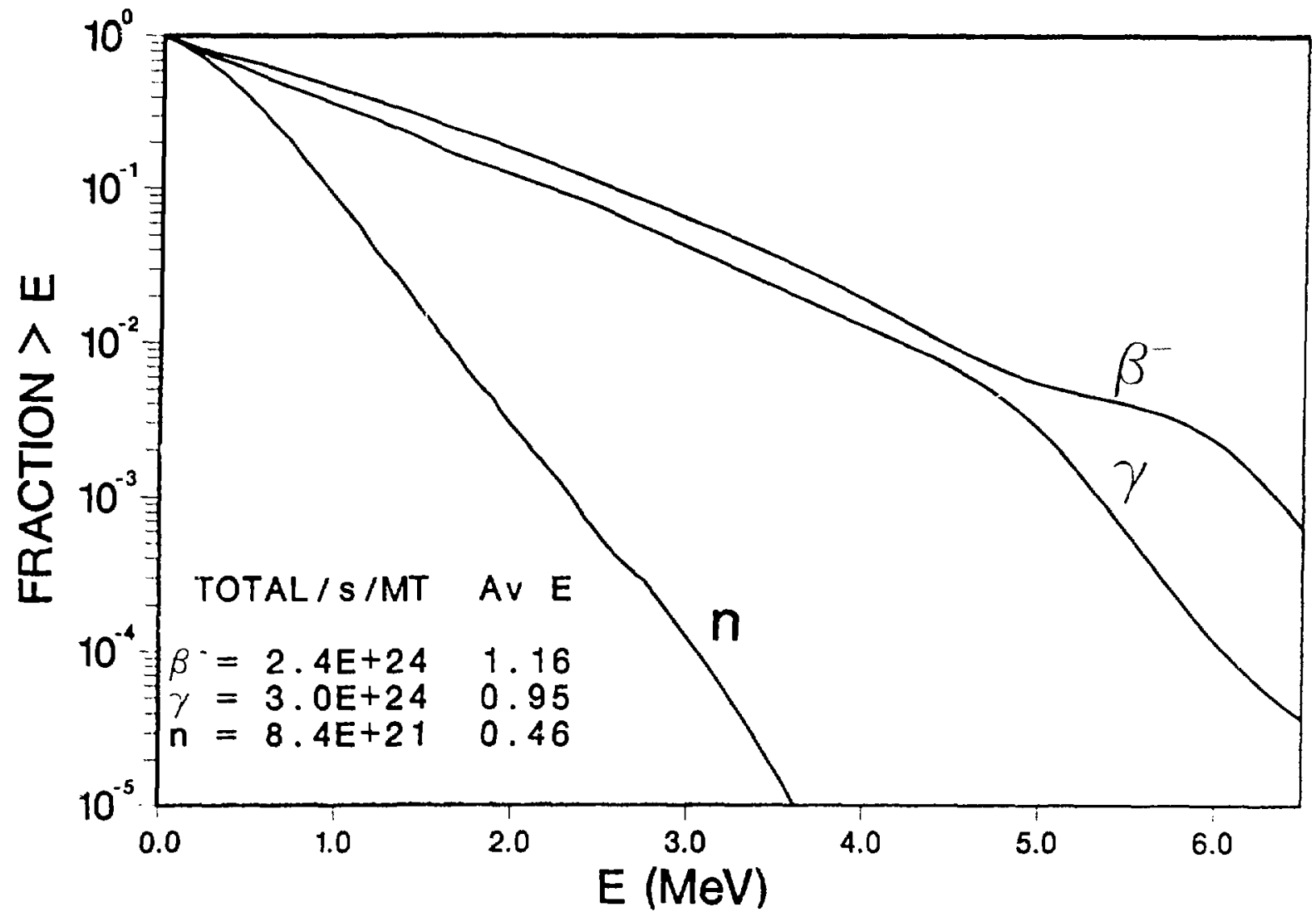

Fig. $43{ }^{235} \mathrm{U}$ Fission: Background at $\mathrm{T}=30 \mathrm{~s}$. 


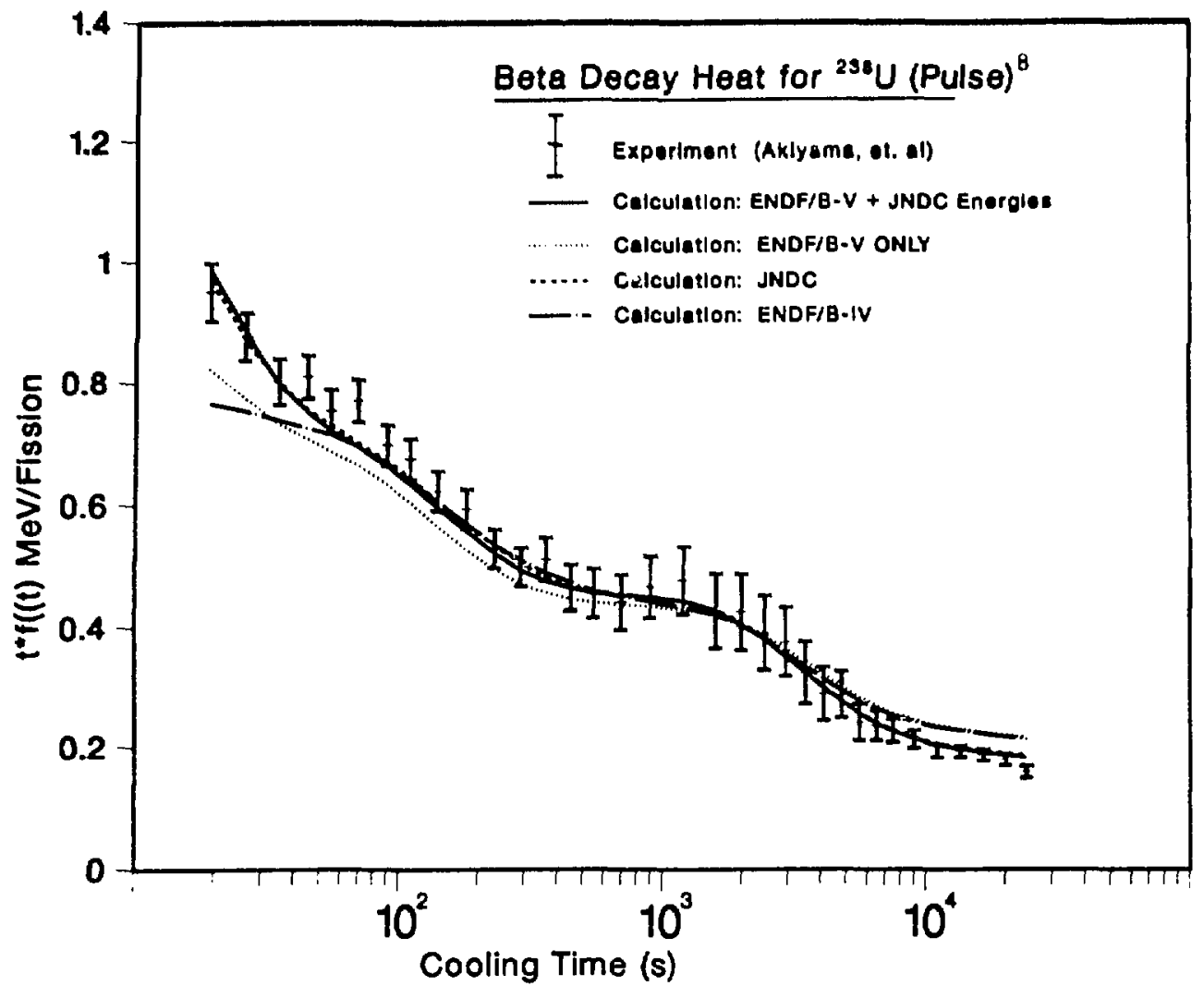

Fig. 44. Beta decay heat for ${ }^{238} \mathrm{U}$ (Pulse).

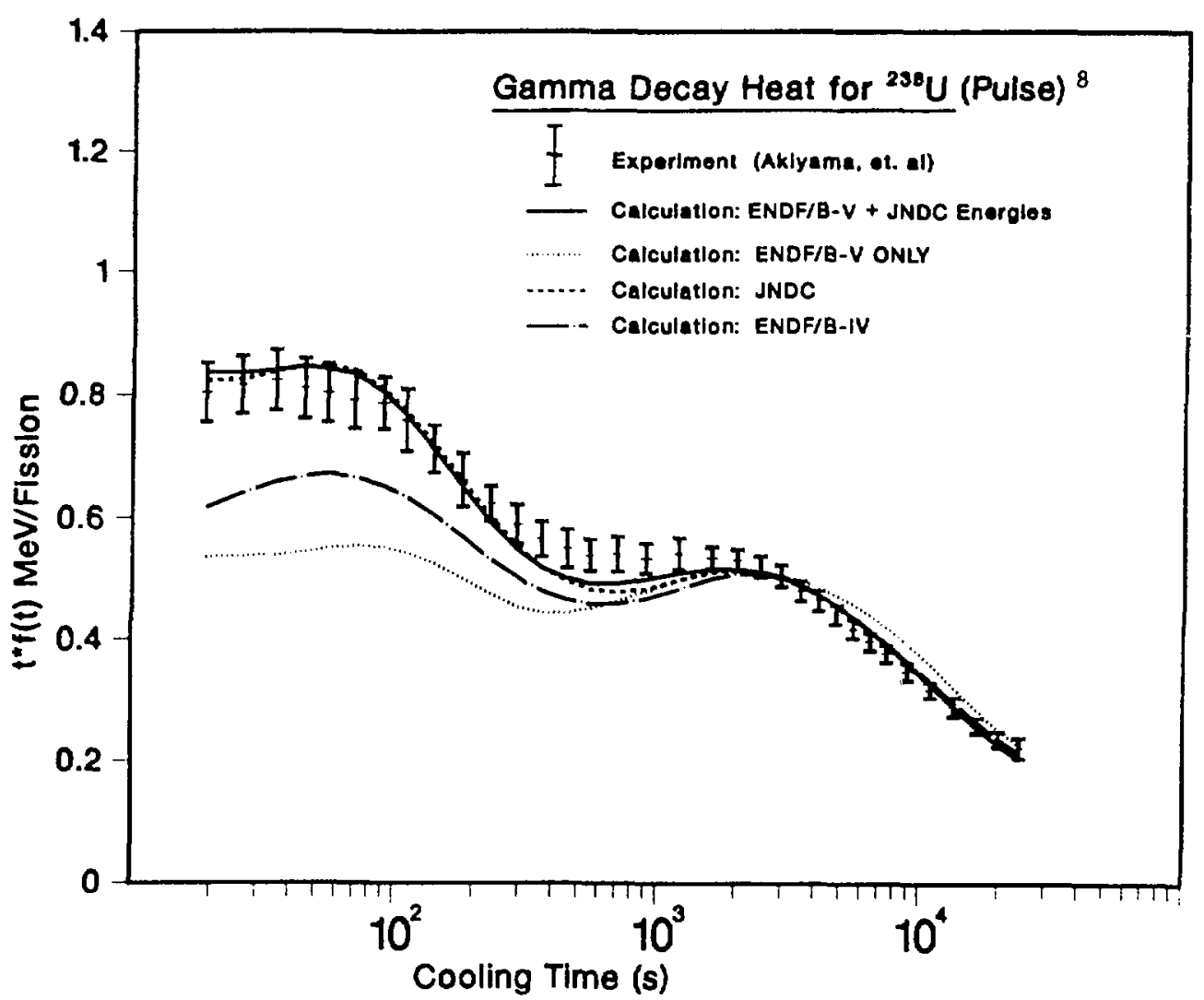

Fig. 45. Gamma decay heat for ${ }^{238} \mathrm{U}$ (Pulse). 


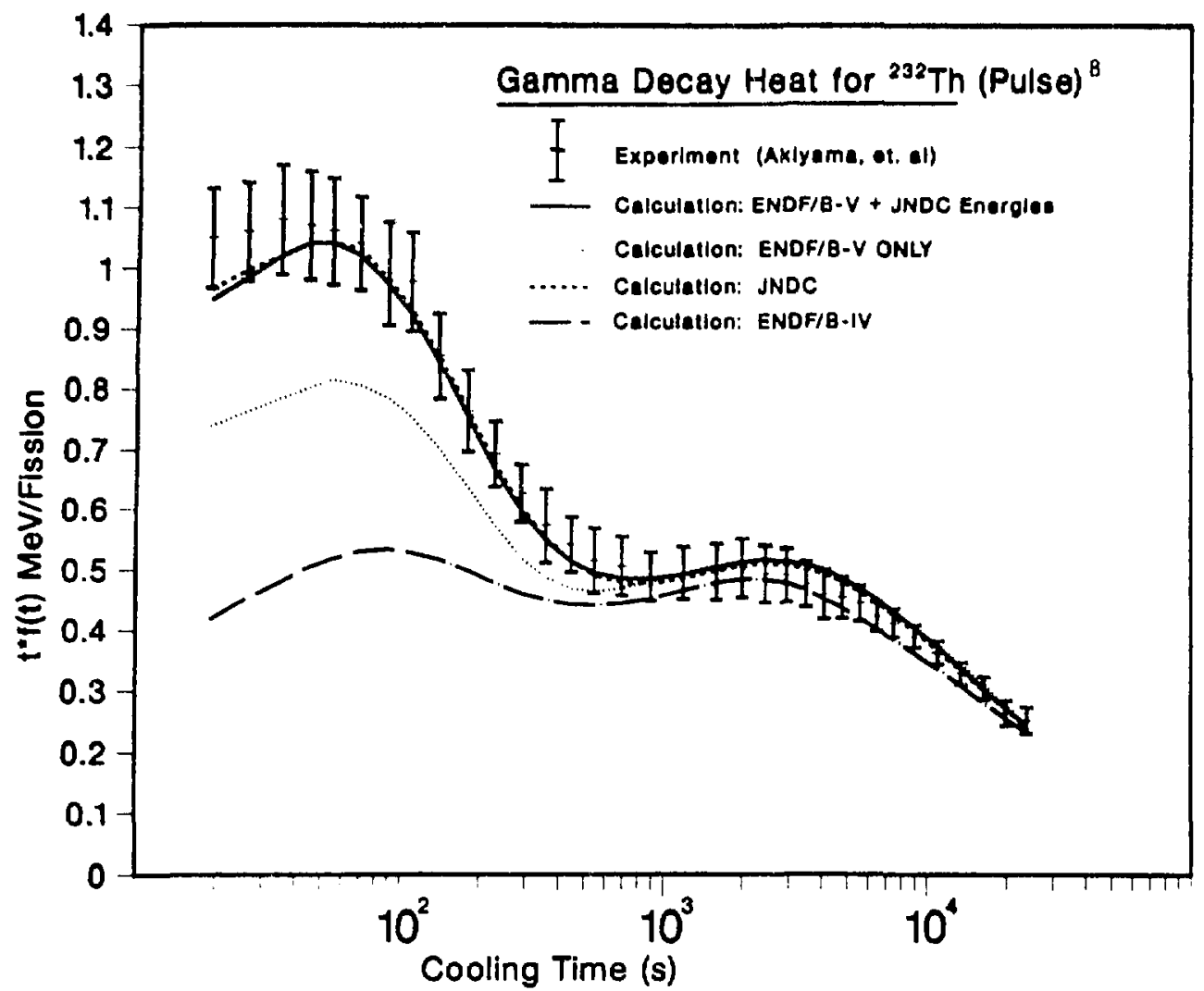

Fig. 46. Gamma decay heat for 232Th (Pulse).

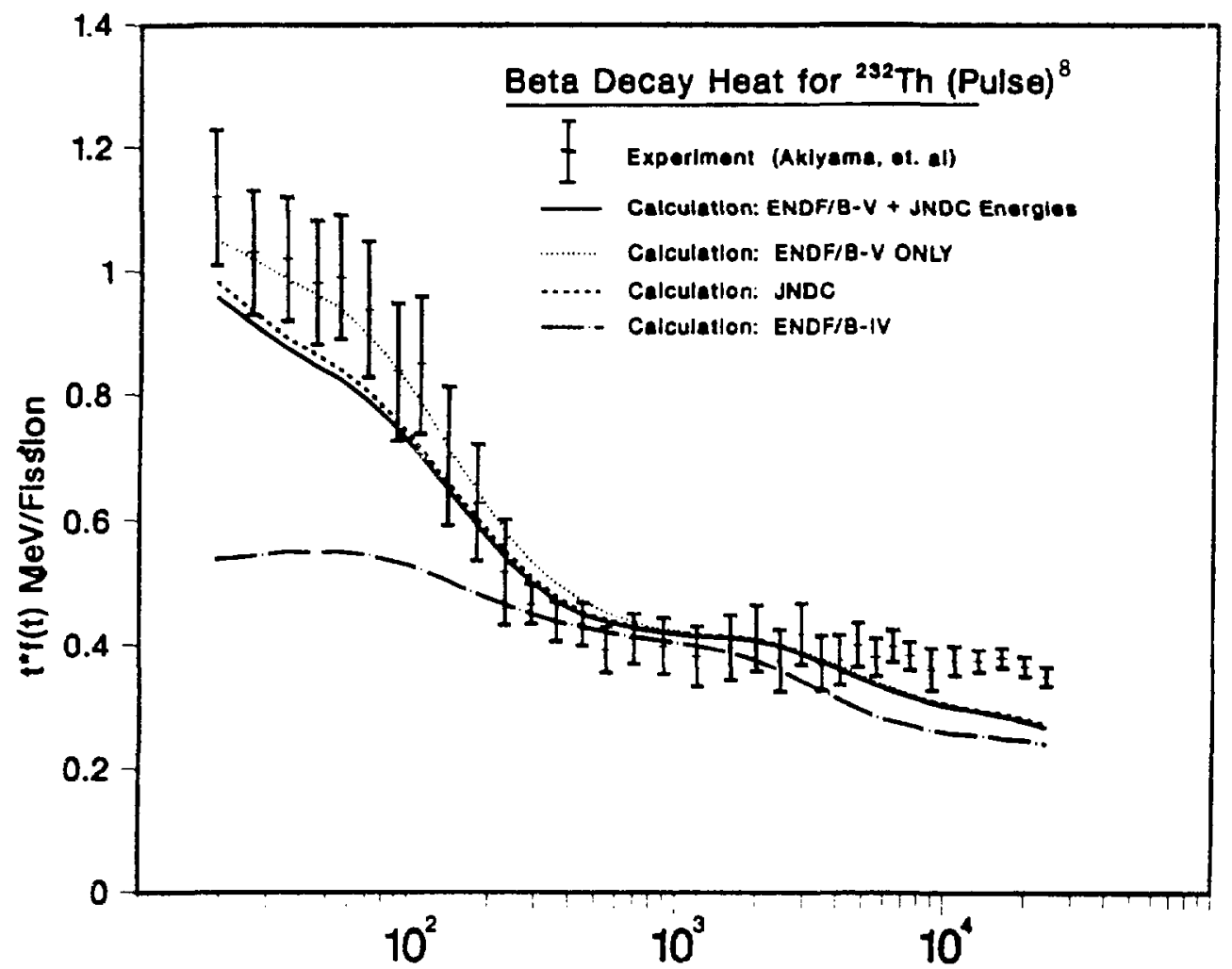

Fig. 47. Beta deciay heat for $232 \mathrm{Th}$ (Pulse). 


\section{SUMMARY}

The dominant radiation fields produced by nuclear devices are neutron, electromagnetic ( $\mathbf{x}$ ray and gamma), and electron, each being prompt and delayed, and all being device dependent. In this report we have focussed on the delayed radiation fields that come from about 800 different radioactive products, 270 of which are delayed neutron emitters and all of which produce spectra of $\beta$ - and $\gamma$ energies. The initial content of this ensemble is characterized by a fission-product yield that varies with the type of device.

To predict this radiation background, we require a complete data base for each product and various application codes. These now exist, but the data bases require improvement because of the emphasis on high radiation energies, the need to examine different fissioning species and devices, and the need to predict fission-product yields from a fission pulse. Some improvements can be made with selected measurements, but many will require nuclear model calculations because of the large number of difficult measurements needed. With sufficient support, progress can be made in updating the necessary data bases during the next year by incorporating US, Japanese, and other measurements, and by developing and applying the necessary model codes.

\section{ACKNOWLEDGMENTS}

Drs. F. M. Mann (Hanford Engineering Development Laboratory), P. L. Reeder (Pacific Northwest Laboratory), C. Goulding (Los Alamos National Laboratory), T. Yoshida (Nippon Atomic Industry Group), K. -L. Kratz (University of Mainz), and G. Rudstam (Swedish Research Councils Laboratory, Studsvik) contributed portions of data used in this report, as did others noted in the references. Several people, in addition to C. Goulding, were involved in the Los Alamos measurements (see Ref. 16). Most of the recent calculations were encouraged and stipported by a Los Alamos program directed by G. F. Auchampaugh and earlier calculations were promoted by O. P. Judd. The basic data development was supported primarily by the US Department of Energy (Basic Energy Sciences). 


\section{REFERENCES}

1. T. R. England, R. Wilczynski, and N. L. Whittemore, "Cinder-7: An Interim Report for Users," Los Alamos Scientific Laboratory report LA-5885-MS (April 1975). [CINDER-10 is a modification of CINDER-7].

2. ENDF/B: Evaiuated Nuclear Data File, available from and maintained by the National Nuclear Data Center, Brookhaven National Laboratory. Version V (ENDF/B-V) is currently available. Some preliminary files for Version VI are essentially complete but are still subject to change.

3. T. R. England and B. F. Rider, "Status of Fission Yield Evaluations," R. E. Chrien and T. W. Burrows, Eds., Proc. NEANDC Specialists' Mtg. on Yields and Decay Data for Fission Product Nuclides, Brookhaven National Laboratory, Upton, N.Y., October 24-27, 1983 (Brookhaven National Laboratory report BNL 51778).

4. T. R. England, W. B. Wilson, R. E. Schenter, and F. M. Mann, "Summary of ENDF/B-V Data for Fission Products and Actinides," Electric Power Research Institute report EPRI NP3787 (December 1984).

5. R. J. LaBauve, T. R. England, and D. C. George, "Integral Data Testing of ENDF/B Fission Product Data and Comparisons of ENDF/B with Other Fission Product Data Files," Los Alamos National Laboratory report LA-9090-MS (ENDF-320) (November 1981).

6. D. C. George, R. J. LaBauve, and T. R. England, "Application of Adjusted Data in Calculating Fission-Product Decay Energies and Spectra," Los Alamos National Laboratory report LA-9362-MS (June 1982).

7. T. R. England, P. G. Young, R. E. Schenter, F. M. Mann, and C. W. Reich, "Fission Product and Actinide Data Status in ENDF/B," paper presented at Twenty-fourth meeting of the Nuclear Energy Agency Nuclear Data Committee, March 12-16, 1984, Tokai-mura, Japan; Los Alamos document LA-UR-84-788.

8. T. Yoshida, M. Akiyama, Z. Matumoto, J. Katakura, and R. Nakasima, "Decay Heat Data Needs," Proc. NEANDC Specialists' Mtg. on Yields and Decay Data for Fission Product Nuclides, Brookhaven National Laboratory report BNL-51778, pp. 265-303 (1983); and J. Katakura, M. Akiyama, T. Yoshida, Z. Matumoto, and R. Nakasima, "An Attempt for Revision of JNDC FP Decay Data Files," Japan Atomic Energy Research Institute JAERI-M 84-117 (1984).

9. J. Katakura and R. Nakasima, "Reevaluation of Decay Energies in JNDC FP Decay Data File, "Japan Atomic Energy Research Institute report JAERI-M 86-041 [NEA NDC9J0 118/U] (March 1986).

10. J. K. Dickens, T. A. Love, J. W. McConnell, J. F. Emery, K. J. Northcutt, and R. W. Peelle, "Delayed Beta- and Gamma-Ray Production Due to Thermal-Neutron Fission of 235U, Spectra Distributions for Times after Fission Between 2 and 14,000 sec: Tabular and Graphical Data," Oak Ridge National Laboratory report NUREG/CR-0162, ORNL/NUREG39 (August 1978). (Also published in Nucl. Sci. Eng.) 
11. J. K. Dickens, T. R. England, T. A. Love, J. W. McConnell, J. F. Emery, K. J. Northcutt, and R. W. Peelle, "Delayed Beta- and Gamma-Ray Production Due to Thermal-Neutron Fission of ${ }^{239} \mathrm{Pu}$ : Tabular and Graphical Spectral Distributions for Times After Fission Between 2 and 14,000 sec," Oak Ridge National Laboratory report NUREG/CR-1172, ORNL/NUREG-66 (January 1980). (Also published in Nucl. Sci. Eng.)

12. F. M. Mann, M. Schreiber, R. E. Schenter, and T. R. England, "Evaluation of DelayedNeutron Emission Probabilities," Nucl. Sci. Eng. 87, 418 (1984); private communication in August 1985.

13. T. R. England, W. B. Wilson, R. E. Schenter, and F. M. Mann, "Aggregate Delayed Neutron Intensities and Spectra Using Augmented ENDF/B-V Precursor Data," Nucl. Sci. Eng. 85, 139 (1983).

14. T. R. England, M. C. Brady, E. D. Arthur, and R. J. LaBauve, "Status of Evaluated Precursor and Aggregate Spectra," Presentation at Specialists' Mtg. on Delayed Neutrons, Birminghaim, England, September 15-19, 1986 (to be published) [see also Los Alamos document LA-UR-86-2983].

15. M. C. Brady, "Evaluation and Application of Delayed Neutron Precursor Data," doctoral dissertation, Texas A \& M University (May 1988)[to be published as a Los Alamos report (thesis series)].

16. H. F. Atwater, C. A. Goulding, C. E. Moss, R. A. Pederson, A. A. Robba, T. R. Wimett, P. L. Reeder, and R. A. Warner, "Delayed Neutron Spectra from Short Pulse Fast Fission of Uranium-235," Proc. of the Specialists' Mtg.. on Delayed Neutrons, Univ. of Birmingham, Birmingham, England, September 15-19, 1986 (to be published).

17. R. C. Greenwood and A. J. Caffrey, "Delayed-Neutron Energy Spectra of ${ }^{93-97} \mathrm{Rb}$ and ${ }^{143-}$ ${ }^{145}$ Cs," Nucl. Sci. Eng. 91, 305 (1985).

18. F. M. Mann, C. Dunn, and R. E. Schenter, "Beta Decay Properties Using a Statistical Model," Phys. Rev. C 25, 1524 (1982).

19. K. -L. Kratz, "Review of Delayed Neutron Energy Spectra," Proc. Consultants' Mtg. on Delayed Neutron Properties, Vienna, Austria, March 26-30, 1979 [International Atomic Energy Agency report INDC NDS -107/G + Special (1979)].

20. G. Rudstam, "Six-Group Representations of the Energy Spectra of Delayed Neutrons from Fission," Nucl. Sci. Eng. 80, 238 (1982).

21. P. Möller and J. R. Nix, "Atomic Masses and Nuclear Ground-State Deformations Calculated with a New Macroscopic-Microscopic Model," Atomic Data and Nuclear Data Tables 26, No. 2, 165-196 (1981).

22. A. H. Wapstra and G. Audi, "The 1983 Atomic Mass Evaluation," Nucl. Phys. A 432, 1-54 (1985).

23. P. L. Reeder, R. A. Warner, R. Gill, and A. Piotrowski, "Pn Measurements at TRISTAN by a Beta-N Coincidence Technique," Proc. of the Specialists' Mtg. on Delayed Neutrons, Univ. of Birmingham, Birmingham, England, September 15-19, 1986 (to be published). 
24. F. M. Mann, "1986 Evaluation of Delayed-Neutron Emission Probabilities," Proc. of the Specialists' Mtg. on Delayed Neutrons, Univ. of Birmingham, Birmingham, England, September 15-19, 1986 (to be published).

25. K. - L. Kratz and G. Herrmann, "Systematics of Neutron Emission Probabilities from Delayed Neutron Frecursors," Z. Physik 263, 435 (1973).

26. M. C. Brady, T. R. England, and W. B. Wilson, "Few-Group Analysis of Current Delayed Neutron Data," Trans. Am. Nucl. Soc. 53, 469 (1986).

27. M. C. Brady and T. R. England, "Few-Group Representation of the Energy Spectra of Delayed Neutrons," Am. Nucl. Soc. 1987 Mtg., Dallas, Texas, June 7-11, 1987, Trans. A.m Nucl. Soc. 54 , 342 (1987). 


\section{APPENDIX A. \\ GENERAL BIBLIOGRAPHY FOR DELAYED NEUTRONS}

(References are listed alphabetically by leading author)

M. Akiyama, Y. Oka, S. Kondo, and S. An, "Fission-Product Decay Heat for FastNeutron Fissions of ${ }^{238} \mathrm{U}$ and ${ }^{232} \mathrm{Th}$," Proc. Int. Conf. Nucl. Data for Basic and Applied Sci., Santa Fe, New Mexico, May 13-17, 1985 (Gordon and Breach Science Pubs., New York), Vol. 1, 743-746.

K. Aleklett, P. Hoff, E. Lund, and G. Rudstam, "Delayed Neutron Emission Probabilities of the Precursors $89,90,91 \mathrm{Br}$ and ${ }^{139,140,141} \mathrm{I}, " \mathrm{Z}$. Phys. A 295 , 331-332 (1980) .

D. R. Alexander and M. S. Krick, "Delayed Neutron Yield Calculations for the NeutronInduced Fission of $235 \mathrm{U}$ as a Function of the Incident Neutron Energy," Nucl. Sci. Eng. $\underline{62}, 627-635$ (1977).

I. Amarel, H. Gauvin and A. Johnson, "Delayed Neutron Emission Probabilities of Rb and Cs Precursors. The Half-life of 97 Rb," J. Inorg. Nucl. Chem. 31, 577-584 (1969).

S. Amiel and H. Feldstein, "A Semi-Empirical Treatment of Neutron Emission Probabilities from Delayed Neutron Precursors," Phys. Lett. 31B, No. 2, 59-60 (1970).

M. Asghar, J. Crancon, J. P. Gautheron, and C. Ristori, "Delayed Neutron Emission

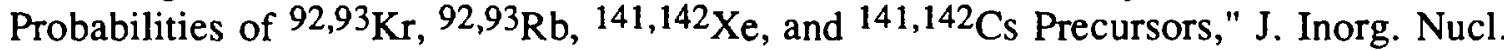
Chem. 37, 1563-1567 (1975).

M. Ashgar, J. P. Gautheron, G. Bailleul, J. P. Bocquet, J. Greif, H. Schrader, G. Siegert, C. Ristori, J. Crancon, and G. I. Crawford, "The Pn Values of the $235 \mathrm{U}(\mathrm{n}$ th, f) Produced Precursors in the Mass Chains 90, 91, 93-95, 99, 134, and 137-139," Nucl. Phys. A 247, 359-376 (1975).

H. F. Atwater, C. A. Goulding, C. E. Moss, R. A. Pederson, A. A. Robba, T. F. Wimett, P. L. Reeder, and R. A. Warner, "Delayed Neutron Spectra from Short Pulse Fast Fission of Uranium-235," Proc. of the Specialists' Mtg. on Delayed Neutrons, U. of Birmingham, Birmingham, England, Sept. 15-19, 1986.

R. Batchelor and H. R. McK. Hyder, "The Energy of Delayed Neutrons from Fission," J. Nucl. Energy $\underline{3}, 7-17$ (1956).

G. Benedetti, A. Cesana, V. Sangiust, M. Terrani and G. Sandrelli, "Delayed Neutron

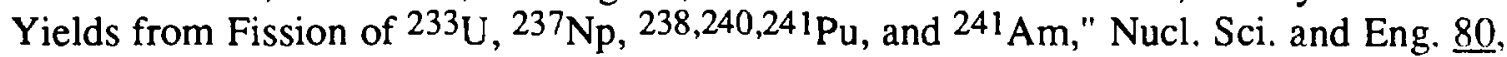
379-387 (1982).

T. Bjornstad, H. A. Gustafsson, P. G. Hanson, B. Jonson, V. Lindfors, S. Mattsson, A. M. Poskanzer and H. L. Ravin, "Delayed Neutron Emission Probabilities of ${ }^{9} \mathrm{Li}$ and ${ }^{11} \mathrm{Li}, "$ Nucl. Phys. A 359, 1-8 (1981). 
J. M. Blatt and V.F. Weisskopf, Theoretical Nuclear Physics, John Wiley and Sons, New York, New York (1952).

T. W. Bonner, S. J. Barne, Jr., and J. E. Evans, "Energy of the Delayed Neutrons from the Fission of ${ }^{235} \mathrm{U}$, " Phys. Rev. 101, 1514-1515 (1956).

M. C. Brady, R. T. Perry, W. B. Wilson, and T. R. England, "Quasi-Analytic Point Reactor Kinetics Calculations Using Individual Precursor Data," Trans. Am. Nucl. Soc. 50, 549 (1985).

M. C. Brady, T. R. England, and W. B. Wilson, "Few Group Analysis of Current Delayed Neutron Data," Trans. Am. Nucl. Soc. 53, 469 (1986).

M. C. Brady and T. R. England, "Few-Group Representation of the Energy Spectra of Delayed Neutrons," Trans. Am. Nucl. Soc. 54, 342-344 (1987). (See also Los Alamos informal document LA-UR 87-48.)

M. Burgy, L. A. Pardue, H. B. Willard and E. O. Wollan, "Energy of Delayed Neutrons from 235U Fissions," Phys. Rev. 70, 104 (1946).

N. G. Chrysochoides, J. N. Anoussis, C. A. Mitsonias, and D. C. Perricos, "Measurement of the Low Energy Spectrum of Delayed Neutrons from ${ }^{87} \mathrm{Br}$ and ${ }^{88} \mathrm{Br}$ Precursors." J. Nucl. Energy 25, 551-556 (1971).

C. Ciarcia, G. Couchell, L. Fisteag, W. Schier, and R. Tanczyn, "Data Reduction and Analysis in Composite Delayed-Neutron Time-of-Flight Studies," Proc. Int. Conf. Nucl. Data for Basic and Applied Sci., Santa Fe, New Mexico, May 13-17, 1985 (Gordon and Breach Science Pubs., New York), Vol. 1, 747-749.

D. D. Clark, R. D. McElroy, T. -R. Yeh, R. E. Chrien, and R. L. Gill, "Neutron Resonances in Nuclides Far From Stability Via Energy Spectra of Beta-Delayed Neutrons," NEANDC Specialists' Mtg. on Yields and Decay Data of Fission Product Nuclides, Brookhaven National Laboratory, Upton, New York, October 24-29, 1983 (BNL-51778), 449-453.

D. D. Clark, T. -R. Yeh, C. -H. Lee, L. -J. Yuan, M. Shmid, R. L. Gill, and R. E. Chrien, "Beta-Delayed Neutron Spectra From 93-97Rb and 143-146Cs," NEANDC Specialists' Mtg. on Yields and Decay Data of Fission Product Nuclides, Brookhaven National Laboratory, Upton, New York, October 24-29, 1983 (BNL-51778), 455-457.

G. P. Couchell, W. A. Schier, D. J. Pullen, L. Fisteag, M. H. Haghighi, Q. Sharfuddin, and R. S. Tanczyn, "Composite Delayed Neutron Spectra for Fast Reactor Kinetics," Proc. of the Specialists' Mtg. on Delayed Neutrons, Univ. of Iirmingham, Birmingham, England, Sept. 15-19, 1986 (to be published).

G. Couchell, R. Tanczyn, L. Fisteag, M. Haghighi, D. Pullen, W. Schier, and Q. Sharfuddin, "Composite Delayed-Neutron Spectra from 235U," Proc. Int. Conf. Nucl. Data for Basic and Applied Sci., Santa Fe, New Mexico, May 13-17, 1985 (Gordon and Breach Science Pubs., New Ycrk), Vol. 1, 707-710.

Samson A. Cox, "Delayed Neutron Data - Review and Evaluation," ANL/NDM-5, April 1974. 
J. Crancon, C. Ristori, H. Ohm, W. Rudolph, K. -L. Kratz, and M. Asghar, "HalfLives and Pn Values of Delayed-Neutron Precursors in the Mass Chains 85-87, 92, 135 , 136 , and 145," Z. Physik A 287, 45-50, (1978).

P. del Marmol, M. Neve de Mevergnies, "Investigation of Delayed Neutron Precursors of As, Sb and Ge," J. Inorg. Nucl. Chem. 29, 273-279 (1967).

P. del Marmol, P. Fettweis, and D. C. Perricos, "On the Delayed Neutron Yields of the Longer-Lived Halogen Precursors in the Thermal Fission of ${ }^{235} \mathrm{U}$," Radiochimica Acta 16 , 4-7 (1971).

P. del Marmol and D. C. Perricos, "Identification of ${ }^{88} \mathrm{Se}$ and Search for Delayed Neutron Emission from ${ }^{87} \mathrm{Se}$ and ${ }^{88} \mathrm{Se}$," J. Inorg. Nucl. Chem. 32, 705-712 (1970). (1969).

P. del Marmol, "Delayed Neutron Precursors," Nuclear Data Tables A $\underline{6}, 141-151$

George W. Eccleston, "Analytical Applications for Delayed Neutrons," NEANDC Specialists' Mtg. on Yields and Decay Data of Fission Product Nuclides, Brookhaven National Laboratory, Upton, New York, October 24- 29, 1983 (BNL-51778), 411-422.

G. W. Eccleston and G. L. Woodruff, "Measured Near-Equilibrium Delayed Neutron Spectra Produced by Fast-Neutron-Induced Fission of ${ }^{232} \mathrm{Th},{ }^{233} \mathrm{U},{ }^{235} \mathrm{U},{ }^{238} \mathrm{U}$ and ${ }^{239} \mathrm{Pu}, "$ Nucl. Sci. and Eng. 62, 636-651 (1977).

T. R. England and B. F. Rider, "Status of Fission Yield Evaluations," NEANDC Specialists' Mtg. on Yields and Decay Data of Fission Product Nuclides, Brookhaven National Laboratory, Upton, New York, October 24- 29, 1983 (BNL-51778).

T. R. England, W. B. Wilson, R. E. Schenter, and F. M. Mann, "Aggregate Delayed Neutron Intensities and Spectra Using Augmented ENDF/B-V Precursor Data," Nucl. Sci. and Eng. 85, 139-155 (1983).

T. R. England, M. C. Brady, W. B. Wilson, R. E. Schenter, and F. M. Mann, "Delayed Neutron Spectra and Intensities from Evaluated Precursor Data," Proc. Int. Conf. Nucl. Data for Basic and Applied Sci., Santa Fe, New Mexico, May 13-17, 1985 (Gordon and Breach Science Pubs., New York), Vol. 1, p. 739 (1986).

T. R. England, M. C. Brady, E. D. Arthur, R. J. LaBauve, "Status of Evaluated Precursor and Aggregate Spectra," Presentation at Specialist' Mtg. on Delayed Neutrons, Birmingham, England, September 15-19, 1986 (to be published). (See also Los Alamos informal document LA-UR 86-2983.)

T. R. England, M. C. Brady, E. D. Arthur, R. J. LaBauve, and F. M. Mann, "Evaluated Delayed Neutron Precursor Data," Trans. Am. Nucl. Soc. 54, 350-352, (1987). (See also Los Alamos informal document LA-UR 87-49.)

T. R. England, R. E. Schenter and F. Schmittroth, "Delayed Neutron Calculations using ENDF/B-V Data," Proc. of the ANS/APS International Conference on Nuclear Cross Sections for Technology, Knoxville, Tenn. (Oct 22-26, 1979). 
T. R. England, W. B. Wilson, R. E. Schenter, and F. Mann, "Delayed Neutron Spectral Calculations Using Augmented ENDF/B-V Data," Trans. Am. Nucl. Soc. 41, 567 (June 1982).

T. R. England, W. B. Wilson, R. E. Schenter, F. M. Mann, "Aggregate Delayed Neutrons and Spectral Calculations Using Preliminary Precursor Data Evaluated for Inclusion in ENDF/B-VI," invited paper, American Chemical Society Symposium on BetaDelayed Neutron Emission, Las Vegas, Nevada, (March 31, 1982). [See also Los Alamos informal document LA-UR-82-841(Rev).]

G. Engler and E. Ne'eman, "Delayed Neutron Emission Probabilities and Half-Lives of $\mathrm{Rb}, \mathrm{Sr}, \mathrm{Y}, \mathrm{In}, \mathrm{Cs}, \mathrm{Ba}$, and $\mathrm{La}$ Precursors with $\mathrm{A}=93-98, \mathrm{~A}=127-131$ and $\mathrm{A}=142-148$," Nucl. Phys. A 367, 29-40 (1981).

A. E. Evans, M. M. Thorpe, and M. S. Krick, "Revised Delayed-Neutron Yield Data," Nucl. Sci. and Eng. 50, 80-82 (1973).

A. E. Evans and M. S. Krick, "Equilibrium Delayed Neutron Spectra from Fast Fission of ${ }^{235} \mathrm{U},{ }^{238} \mathrm{U}$, and ${ }^{239} \mathrm{Pu}$," Nucl. Sci. and Eng., 62, 652-659 (1977). 11 .

Robley D. Evans, The Atomic Nucleus, McGraw Hill Book Co., Inc. (1955), Chapter

G. T. Ewan, P. Hoff, B. Jonson, K. -L. Kratz, P. O. Larson, G. Nyman, H. L. Ravin, and W. Ziegert, "Intense Mass-Separated Beams of Halogens and Beta-Delayed Neutron Emission from Heavy Bromine Isotopes," Z. Phys. A 318, 309-314 (1984).

E. Feenberg and G. Trigg, "The Interpretation of Comparative Half-Lives in the Fermi Theory of Beta Decay," Rev. Mod. Phys. 22, 399-406 (1950).

G. Fieg, "Measurements of Delayed Fission Neutron Spectra of ${ }^{235} \mathrm{U},{ }^{238} \mathrm{U}$, and ${ }^{239} \mathrm{Pu}$ with Proton Recoil Proportional Counters," J. Nucl. Energy 26, 585-592 (1972).

H. Franz, W. Rudolph, H. Ohm, K. -L. Kratz, G. Herrmann, F. M. Nuh, D. R. Slaughter, and S. G. Prussin, "Delayed-Neutron Spectroscopy with He-3 Spectrometers," Nucl. Instr. and Meth. 144, 253-261 (1977).

H. Franz, J. -V. Kratz, K. -L. Kratz, W. Rudolph, and G. Herrmann, "DelayedNeutron Spectra Following Decay of ${ }^{85}$ As and ${ }^{135}$ Sb," Phys. Rev. Lett. $\underline{33}$, 14, 859 (1974).

H. Gabelmann, J. Munzel, B. Pfeiffer, G. I. Crawford, H. Wollnik and K. -L. Kratz, "Pn-values of Short-lived Sr, Y, Ba, and La Precursors," Z. Phys. A $\underline{308}, 359-360$ (1982).

O. K. Gjotterud, P. Hoff, and A. C. Pappas, "Detailed Structure of Delayed Neutron Spectra," Nucl. Phys. A $303,295-312$ (1978).

O. K. Gjotterud, P. Hoff, and A. C. Pappas, "Gross Properties of Delayed Neutron Spectra," Nucl. Phys. A 303, 281-294 (1978).

Patrick J. Grant and Gene L. Woodruff, "Near-Equilibrium Measurements of Delayed Neutron Spectra from Fast Fission of ${ }^{240} \mathrm{Pu}$," Nucl. Sci. and Eng. 76, 56-62 (1980). 
R. C. Greenwood and A. J. Caffrey, "Delayed-Neutron Energy Spectra of ${ }^{93-97} \mathrm{Rb}$ and 143-145Cs," Nucl. Sci. and Eng. 91, 305-323 (1985).

R. C. Greenwood and A. J. Caffrey, "Measuring Delayed Neutron Spectra-A Comparision of Techniques," NEANDC Specialists' Mtg. on Yields and Decay Data of Fission Product Nuclides, Brookhaven National Laboratory, Upton, New York, October 24-29, 1983 (BNL-51778), 365-393.

$\mathrm{Ph}$. Hammer, "Review of the Requirements of Delayed Neutron Data for the Design, Operation, Dynamics and Safety of Fast Breeder and Thermal Power Reactors," Proc. Consultants' Mtg. on Delayed Neutron Properties, Vienna, Austria, March 26-30, 1979 [International Atomic Energy Agency report INDC NDS-107/G+Special (1979)], p. 1.

P. G. Hansen and B. Jonson, "Beta-Delayed Particle Emission from Neutron-Rich Nuclei," CERN-EP/87-44, 26 February 1987 (Contribution prepared for the book 'Particle Emission from Nuclei', Eds., M. Ivasen and D. Poenaru (to be published by the CRC Press).

D. J. Hughes, J. Dabbs, A. Cahn, and D. Hall, "Delayed Neutrons from Fission of 235U," Phys. Rev. 73, 111-124 (1948).

T. Izak-Biran and S. Amiel, "Reevaluation of the Emission Probabilities of Delayed Neutrons from Fission Products," Nucl. Sci. and Eng. 57, 117-121 (1975).

K. (Aleklett) Johansson, G. Nyman, and G. Rudstam, "Beta-Decay Properties of Strongly Neutron-Rich Nuclei," Nucl. Phys. A 246, 425-444 (1975).

G. R. Keepin, T. F. Wimett, and R. K. Zeigler, "Delayed Neutrons from Fissionable Isotopes of Uranium, Plutonium, and Thorium," Phys. Rev. 107, 1044,1049 (1957).

G. R. Keepin, T. F. Wimett, and R. K. Zeigler, "Delayed Neutrons from Fissionable Isotopes of Uranium, Plutonium, and Thorium," J. Nucl. Energy $\underline{6}, 1-21$ (1957).

G. R. Ke:spin, "Delayed Neutrons," Progress in Nucl. Energy I, 191-225 (1956).

G. R. Keepin, Physics of Nuclear Kinetics, Addison-Wesley Publishing Co., Reading, Massachusetts (1956), Chapter 4.

G. R. Keepin, "Interpretation of Delayed Neutron Phenomena," J. Nucl. Energy I, 1334 (1958).

G. R. Keepin, "Prediction of Delayed Neutron Precursors," Phys. Rev. 106, 1359-1360 (1957).

H. V. Klapdor, "Beta Decay Far From Stability and Its Role in Nuclear Physics and Astrophysics," presented at the International School-Seminar on Heavy Ion Physics, Alushta, Crimea, USSR, 14-21 April 1983.

H. V. Klapdor, "Beta Decay Calculations and their Applications in Nuclear Technology and Astrophysics," KTG/ENS-International State of the Art Seminar on Nuclear Data, Cross Section Libraries and their Application in Nuclear Technology, October 1-2, 1985, Wissenschaftszentrum, Bonn. 
E. J. Konopinski, "Beta-Decay," Rev. Mod. Phys. 15, 209-245, (1943).

J. -V. Kratz, H. Franz, and G. Herrmann, "Delayed-Neutrons from Arsenic Isotopes ${ }^{84} \mathrm{As},{ }^{85} \mathrm{As}$, and ${ }^{86} \mathrm{As}, "$ J. Inorg. Nucl. Chem. 35, 1407-1417 (1973).

J. -V. Kratz and G. Herrmann, "Half-lives, Fission Yields, and Neutron Emission Probabilities of ${ }^{87} \mathrm{Se}$ and ${ }^{88} \mathrm{Se}$, and Evidence for ${ }^{87} \mathrm{As}$," J. Inorg. Nucl. Chem. $\underline{32}$, 3713 3723 (1970).

K. -L. Kratz, W. Rudolph, H. Ohm, H. Franz, M. Zendel, G. Herrmann, S. G. Prussin, F. M. Nuh, A. A. Shihab-Eldin, D. R. Slaughter, W. Halverson, and H. V. Klapdor, "Investigation of Beta Strength Functions by Neutron and Gamma-Ray Spectroscopy (I). The Decay of ${ }^{87} \mathrm{Br},{ }^{137} \mathrm{I},{ }^{85} \mathrm{As}$, and ${ }^{135} \mathrm{Sb}$.," Nucl. Phys. A $\underline{317}$, 335$362(1979)$.

K. -L. Kratz, A. Schroder, H. Ohm, M. Zendel, H. Gabelmann, W. Zeigert, P. Peuser, G. Jung, B. Pfeiffer, K. D. Wunsch, H. Wollnik, C. Ristori, and J. Crancon, "BetaDelayed Neutron Emission from ${ }^{93-100} \mathrm{Rb}$ to Excited States in the Residual Sr Isotopes," $\mathrm{Z}$. Phys. A 306, 239-257 (1982).

K. - L. Kratz and G. Herrmann, "Systematics of Neutron Emission Probabilities from Delayed Neutron Precursors," Z. Physik 263, 435-442 (1973).

K. -L. Kratz and H. Gabelmann, "Beta-Delayed Neutron Spectra for Application in Reactor Technology, Nuclear Physics and Astrophysics," Proc. Int. Conf. Nucl. Data for Basic and Applied Sci., Santa Fe, New Mexico, May 13-17, 1985 (Gordon and Breach Science Pubs., New York), Vol. 1, 661-672.

K. -L. Kratz, "Review of Delayed Neutron Energy Spectra," Proc. Consultants Mtg. on Delayed Neutron Properties, Vienna, Austria, March 26-30, 1979 [International Atomic Energy Agency report INDC NDS-107/G + Special (1979)].

K. -L. Kratz, "The Beta-Decay of ${ }^{95} \mathrm{Rb}$ and ${ }^{97} \mathrm{Rb}$," Z. Phys. A 312, 43-57 (1983).

K. -L. Kratz, W. Rudolph, H. Ohm, H. Franz, G. Herrmann, C. Ristori, J. Crancon, M. Asghar, G. I. Crawford, F. M. Nuh, and S. G. Prussin, "Decay of Individual Levels in Delayed Neutron Emitters to Excited States in the Final Nuclei," Phys. Lett. 65B, 3, 231 (1976).

K. -L. Kratz and G. Herrmann, "Delayed-Neutron Emission from Short-Lived Br and I Isotopes," Nucl. Phys. A 229, 179-188 (1974).

M. S. Krick and A. E. Evans, "The Measurement of Total Delayed-Neutron Yields as a Function of the Energy of the Neutron Inducing Fission," Nucl. Sci. Eng. 47, 311-318 (1972).

J. R. Liaw and T. R. England, "Some Integral Tests on ENDF/B-IV Based On Conservation Principles," Proceedings of the "Topical Conference on Advances in Reactor Physics, ' Gatlinburg, Tenn. April 10-12, 1978.

J. R. Liaw and T. R. England, "Calculations of Delayed-Neutron Yields fron. NDF/BVC," Trans. Am. Nucl. Soc. $\underline{28}, 750$ (June 1978). 
E. Lund, G. Rudstam, K. Aleklett, B. Ekstron, B. Fogelberg, and L. Jacobsen, "A Status Report on Delayed Neutron Branching Ratios of Fission Products and the Delayed Neutron Program at OSIRIS Using the New Ion-Source ANUBIS," Proc. of the Specialists' Mitg. on Delayed Neutrons, Univ. of Birmingham, Birmingham, England, Sept. 15-19, 1986 (to be published).

E. Lund, P. Hoff, K. Aleklett, O. Glomset, and G. Rudstam, "Delayed Neutron Emission Probabilities of Gallium, Bromine, Rubidium, Indium, Antimony, Iodine and Cesium Precursors," Z. Phys. A 294, 233-240 (1980).

B. P. Maksyutenko, "Relative Yields of Delayed Neutrons in Fission of ${ }^{238} \mathrm{U},{ }^{235} \mathrm{U}$, and 232Th by Fast Neutrons," J. Exptl. Theoret. Phys., (USSR), 35, 815-816 (1958).

B. P. Maksyutenko, "Absolute Yields of Delayed Neutrons in the Fission of $238 \mathrm{U}, 235 \mathrm{U}$, and 232 Th by Fast Neutrons," Atomnaya Energiya Z, No. 5, 474-475 (1959).

F. M. Mann, M. Schreiber R. E. Schenter, and T. R. England, "Evaluation of DelayedNeutron Emission Probabilities," Nucl. Sci. and Eng. 87, 418-431(1984).

F. M. Mann, C. Dunn, and R. E. Schenter, "Beta Decay Properties from a Statistical Model," Trans. Am. Nucl. Soc. 39, 880-883 (1981).

F. M. Mann, C. Dunn, and R. E. Schenter, "Beta Decay Properties Using a Statistical Model," Phys. Rev. C 25, 1, 524-526(1982).

F. M. Mann, "Calculating Beta Decay Properties in the Fission Product Region," NEANDC Specialists' Mtg. on Yields and Decay Data of Fission Product Nuclides, Brookhaven National Laboratory, Upton, New York, October 24-29, 1983 (BNL-51778) 449-453.

F. M. Mann, "1986 Evaluation of Delayed-Neutron Emission Probabilities," Proc. of the Specialists' Mtg. on Delayed Neutrons, Univ. of Birmingham, Birmingham, England, Sept. 15-19, 1986 (to be published).

F. M. Mann, M. Schreiber, R. E. Schenter, and T. R. England, "Compilation of Neutron Precursor Data," Trans. Am. Nucl. Soc. 45, 704 (Oct.-Nov. 1983).

C. F. Masters, M. M. Thorpe, and D. B. Smith, "The Measurement of Absolute Delayed-Neutron Yields from 3.1- and 14.9-MeV Fission," Nucl. Sci. Eng. 36, 202-208 (1969).

G. Moscati and J. Goldenberg, "Delayed Neutron Yields in the Photo-fission of ${ }^{238} \mathrm{U}$ and 232Th," Phys. Rev. 126, 3, 1098 (1962).

S. A. Moszkowski, "A Rapid Method for Calculating $\log (\mathrm{ft})$ Values for BetaTransitions," Phys. Rev. 82, 35-37 (1951).

F. M. Nuh, D. R. Slaughter, S. G. Prussin, H. Ohm, W. Rudolph, and K. -L. Kratz, "Delayed Neutrons and High-Energy Gamma-Rays from Decay of ${ }^{87} \mathrm{Br}$," Nucl. Phys. A 293, 410-424 (1977). 
H. L. Pai and D. G. Andrews, "The Systematics of the $(n, 2 n)$ Cross Section (the CsikajPeto Effect)," Can. J. Phys. 55, 2145 (1977).

H. L. Pai and D. G. Andrews, "A Simple Formula for Calculation of Prompt Neutron Yield from Spontaneous Fission of Transuranics," Nucl. Sci. and Eng. 76, 323-330 (1980),

A. C. Pappas and G. Rudstam, "An Approach to the Systematics of Delayed Neutron Precursors," Nucl. Phys. 21, 353-366 (1960).

A. C. Pappas and T. Sverdrup, "Gross Properties of Delayed Neutron Emission and Beta-Strength Functions," Nucl. Phys. A 188, 48-64 (1972).

R. T. Perry, W. B. Wilson, T. R. England, and M. C. Brady, "Application of Evaluated Fission-Product Delayed Neutron Precursor Data in Reactor Kinetics Calculations," Proc. Int. Conf. Nucl. Data for Basic and Applied Sci., Santa Fe, New Mexico, May 13-17, 1985 (Gordon and Breach Science Pubs., New York), Vol. 1, 717 (1986).

P. Peuser, H. Otto, M. Weis, G. Nyman, E. Roeckl, J. Bonn, L. von Reisky, and C. Spath, "Half-lives, Neutron Emission Probabilities and Fission Yields of Neutron-Rich Rubidium Isotopes in the Mass Region A=96 to A=100," Z. Phys. A $\underline{289}, 219-224$ (1979).

P. Reeder, R. Warner, T. Yeh, R. Chrien, R. Gill, M. Shmid, H. Liou, and M. Stelts, "Beta-Delayed Two-Neutron Emission from ${ }^{98}$ Rb," Phys. Rev. Lett. 47, 7, 483 (1981).

P. L. Reeder, L. J. Alquist, R. L. Kiefer, F. H. Ruddy, and R. A. Warner, "Energy Spectra of Delayed Neutrons from the Separated Precursors 93,94,95Rubidium and ${ }^{143}$ Cesium," Nucl. Sci. and Eng. 75, 140-150 (1980).

P. L. Reeder and R. A. Warner, "Average Energy of Delayed Neutrons from Individual Precursors and Estimation of Equilibrium Spectra," Nucl. Sci. and Eng. 79, 56-64 (1981).

P. L. Reeder, R. A. Warner, R. Gill, and A. Piotrowski, "Pn Measurements at TRISTAN by a Beta-N Coincidence Technique," Proc. of Specialists' Mtg. on Delayed Neutrons, Univ. of Birmingham, Birmingham, England, Sept. 15-19, 1986 (to be published).

P. L. Reeder and R. A. Warner, "Delayed Neutron Data from TRISTAN," Proc. Int. Conf. Nucl. Data for Basic and Applied Sci., Santa Fe, New Mexico, May 13-17, 1985 (Gordon and Breach Science Pubs., New York), Vol. 1, 701-705.

P. L. Reeder, "Status of and Outstanding Problems in Delayed Neutron Data, Pn Values and Energy Spectra," Proc. of the Conf. on Nuclear Data Evaluation Methods and Procedures, Brookhaven National Laboratory, Upton, New York, September 22-25, 1980 (BNL-NCS-51363).

P. L. Reeder, "Survey of Delayed Neutron Emission Probabilities," NEANDC Specialists' Mtg. on Yields and Decay Data of Fission Product Nuclides, Brookhaven National Laboratory, Upton, New York, October 24-29, 1983 (BNL-51778), 337-364. 
P. L. Reeder and R. A. Warner, "Distribution of Delayed Neutron Yields Versus Proton, Neutron, and Mass Numbers: Application to Proton Pairing in Fission Yields," Nucl. Sci. and Eng. 87, 181-194 (1984).

P. L. Reeder and R. A. Warner, "Delayed Neutron Precursors at Masses 97-99 and 146148," Phys. Rev. C 288, 1740-1751 (1983).

P. L. Reeder, J. F. Wright, and L. J. Alquist, "Delayed-Neutron Emission Probabilities of Separated Isotopes of Br, Rb, I and Cs.," Phys. Rev. C 15, 2108-2118 (1977).

P. L. Reeder, R. A. Warner, R. M. Liebsch, R. L. Gill, and A. Piotrowski, "Delayed Neutron Precursor ${ }^{75} \mathrm{Cu}$," Phys. Rev. C 31, 1029-1031 (1985).

C. Ristori, J. Crancon, K. D. Wunsch, G. Jung, R. Decker, and K. -L. Kratz, "Halflives and Delayed Neutron Emission Probabilities of Short-Lived Rb and Cs Precursors," Z. Phys. A 290, 311-318 (1979).

R. B. Roberts, L. R. Hofstad, R. C. Meyer, and P. Wang, "The Delayed Neutron Emission which Accompanies Fission of Uranium and Thorium," Phys. Rev. 55, 664 (1939).

R. B. Roberts, R. C. Meyer, and P. Wang, "Further Observations on the Splitting of Uranium and Thorium," Phys. Rev. 52, 510-511 (1939).

E. Roeckl, P. F. Dittner, R. Kalpisch, C. Thibault, C. Rigaud, and R. Prieels, "Delayed Neutron Emission from the Decay of Neutron-Rich Rb and Cs Isotopes," Nucl. Phys. A 222, 621-628 (1974).

W. Rudolph, K. -L. Kratz, and G. Herrmann, "Half-lives, Fission Yields and Neutron Emission Probabilities of Neutron-Rich Antimony Isotopes," J. Inorg. Nucl. Chem. 39, 753-758 (1977).

W. Rudolph and K. -L. Kratz, "Attempt to Calculation of Delayed Neutrons Emission Probabilities using Simple Statistical Model Considerations," Z. Physik A 281, 269-275 (1977).

G. Rudstam and E. Lund, "Energy Spectra of Delayed Neutrons from the Precursors ${ }^{79}(\mathrm{Zn}, \mathrm{Ga}),{ }^{80} \mathrm{Ga},{ }^{81} \mathrm{Ga},{ }^{94} \mathrm{Rb},{ }^{95} \mathrm{Rb},{ }^{129} \mathrm{In}$, and ${ }^{130} \mathrm{In}$," Nucl. Sci. and Eng. 64, 749-760 (1977).

G. Rudstam, "Status of Delayed Neutron Data," Proc. 2nd IAEA Advisory Group Mtg. on Fission Product Nuclear Data, Petten, Netherlands, September 5-9, 1977, Vol. 2, 567.

G. Rudstam, "Six-Group Representation of the Energy Spectra of Delayed Neutrons from Fission," Nucl. Sci. and Eng. 80, 238-255 (1982).

G. Rudstam and S. Shalev, "Energy Spectra of Delayed Neutrons from Separated Fission Products," Nucl. Phys. A 235, 397-409 (1974).

G. Rudstam, "Characterization of Delayed-Neutron Spectra," Journal of Radioanalytical Chem. 36, 591-618 (1977). 
G. Rudstam, "The Uncertainty of Neutron Energy Spectra Deduced from Measured Pulse Spectra in a ${ }^{3} \mathrm{He}$ Spectrometer," Nucl. Inst. and Methods 177, 529-536 (1980).

G. Rudstam, "Review of Delayed Neutron Branching Ratios," Proc. Consultants Mtg. on Delayed Neutron Properties, Vienna, Austria, March 26-30, 1979 [International Atomic Energy Agency report INDC NDS-107/G+Special (1979)], 69.

G. Rudstam, S. Shalev, and O. C. Jonsson, "Delayed Neutron Emission from Separated Fission Products," Nucl. Instr. Method 120 333-344 (1974).

D. Saphier, D. Ilberg, S. Shalev, and S. Yiftah, "Evaluated Delayed Neutron Spectra and Their Importance in Reactor Calculations," Nucl. Sci. and Eng. 62, 660-694 (1977).

W. Schier, Q. Sharfuddin, G. Couchell, L. Fisteag, M. Haghighi, D. Pullen, and R. Tanczyn, "Search for Energy Dependence Among Composite Delayed Neutron Spectra of 235U," Proc. Int. Conf. Nucl. Data for Basic and Applied Sci., Santa Fe, New Mexico, May 13-17, 1985 (Gordon and Breach Science Pubs., New York), Vol. 1, 751-754.

H. -D. Schussler and G. Herrmann, "Hauptkomponenten unter den Vorlaufern Verzogerter Neutronen bei der Spaltung von Uran-235 durch thermische Neutronen," Radiochimica Acta 18, 13-144 (1972).

S. Shalev and G. Rudstam, "Energy Spectra of Delayed Neutrons from Separated Fission Products," Nucl. Phys. A 275, 76-92 (1977).

S. Shalev and J. M. Cuttler, "The Energy Distribution of Delayed Fission Neutrons," Nucl. Sci. and Eng. 51, 52-66 (1973).

S. Shalev and G. Rudstam, "Energy Spectra of Delayed Neutrons from Separated

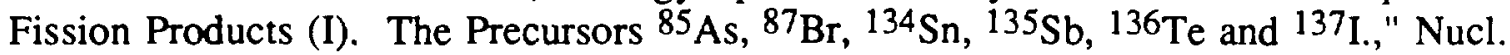
Phys. A 230, 153-172 (1974).

S. Shalev and G. Rudstam, "Delayed Neutron Emission from ${ }^{137}$ I," Phys. Rev. Lett. 28, 687-690 (1972).

W. R. Sloan and G. L. Woodruff, "Spectrum of Delayed Neutrons from the Thermal

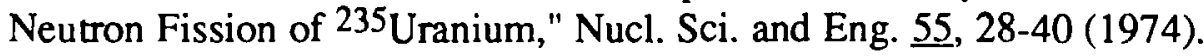

M. G. Stamatelatos and T. R. England, "Accurate Approximations to Average BetaParticle Energies and Spectra," Nucl. Sci. Eng. 63, 204-208 (1977).

S. Synetos, J. G. Williams, "Delayed Neutron Yield and Decay Constants for Thermal Neutron-Induced Fission of 235U," Nucl. Energy 22, 267-274 (1983).

R. S. Tanczyn, Q. Sharfuddin, W. A. Schier, D. J. Pullen, M. H. Haghighi, L. Fisteag, and G. P. Couchell, "Composite Delayed Neutron Energy Spectra for Thermal Fission of ${ }^{235}$ U," Nucl. Sci. and Eng.94, 353-364 (1986).

K. Takahashi, "Application of the Gross Theory of Beta-Decay to Delayed Neutron Emissions," Prog. of Theor. Phys. 47, No. 5 (1972). 
K. Takahashi and M. Yamada, "Gross Theory of Nuclear Beta-Decay," Prog. of 'Theor. Phys. 41, 1470-1503 (1969).

K. Takahashi, "Gross Theory of First Forbidden Beta-Decay," Prog. of Theor. Phys. 45, 1466-1492 (1969).

W. L. Talbert, Jr., A. B. Tucker, and G. M. Day, "Delayed Neutron Emission in the Decays of Short-Lived Separated Isotopes of Gaseous Fission Products," Phys. Rev. 177, 1805-1816 (1969).

L. Tomlinson and M. H. Hurdus, "Delayed Neutron Precursors - I; Antimony and Arsenic Precursors Separated by Electrolysis,".J. Inorg. Nucl. Chem. 30, 1125-1138 (1968),

L. Tomlinson and M. H. Hurdus, " Delayed Neutron Precursors - III Selenium-87," J. Inorg. Nucl. Chem. 30, 1995-2002 (1968).

L. Tomlinson, "Delayed Neutron Precursors, " Atomic Data and Nuclear Data Tables 12, 179-194 (1973).

L. Tomlinson and M. H. Hurdus, "A New Antimony Delayed Neutron Precursor," Phys. lett. 25B, 9, 545 (1967).

L. Toinlinson, "Theory of Delayed Neutron Physics," United Kingdom Atomic Energy Authority Research Group Report, Chemistry Division, Atomic Energy Research Establishment, Harwell, Berkshire, AERE-R 6596 (1970).

L. Tomlinson and M. H. Hurdus, "Antimony and Arsenic Precursors Separated Chemically," J. Inorg. Nucl. Chem. 30, 1649-1661 (1968).

L. Tomlinson and M. H. Hurdus, ${ }^{87} \mathrm{Se},{ }^{88} \mathrm{Se}$, and ${ }^{89} \mathrm{Se}$; Half-lives, Neutron Emission Probabilities and Fission Yields," J. Inorg. Nucl. Chem. 33, 3609-3620 (1971).

R. J. Tuttle, "Delayed-Neutron Data for Reactor-Physics Analysis," Nucl. Sci. and Eng. 56, 37-71 (1975).

R. J. Tuttle, "Review of Delayed Neutron Yields in Nuclear Fission," Proc. Consultants' Mig. on Delayed Neutron Properties, Vienna, Austria, March 26-30, 1979 [International Atomic Energy Agency report INDC NDS-107/G+Special (1979)], p. 29.

R. W. Waldo, R. A. Karam, "Measured Delayed Neutron Yields," Trans. Am. Nucl. Soc. 39, 879-880 (1982).

R. W. Waldo, R. A. Karam, and R. A. Meyer, "Delayed Neutron Yiclds: Time Dependent Measurements and a Predictive Model," Phys. Rev. C 23, 3, 1113-1127 (1981).

J. Walker, D. R. Weaver, J. G. Owen, and S. J. Chilton, "Extended Analysis of Delayed Neutron Spectra from Fast Fission in U-235," Proc. Int. Conf. Nucl. Data for Basic and Applied Sci., Janta Fe, New Mexico, May 13-17, 1985 (Gordon and Breach Science Pubs., New York), Vol. 1, 775-778. 
A. H. Wapstra and G. Audi, "The 1983 Atomic Mass Evaluation," Nucl. Phys. A 432 , 1, (1985).

D. R. Weaver, J. G. Owen, and J. Walker, "Delayed Neutron Spectrum Measurements and Covariance Anaylsis," NEANDC Specialists' Mtg. on Yields and Decay Data of Fission Product Nuclides, Brookhaven National Laboratory, Upton, New York, October 24-29, 1983 (BNL-51778), 459-467.

C. S. Wu, "Recent Investigation of the Shapes of Beta-Ray Spectra," Rev. Mod. Phys. $\underline{22}, 386-398(1950)$.

T. R. Yeh, D. D. Clark, G. Scharff-Goldhaber, M. Shmid, R. L. Gill, L. Yuan, R. E. Chrien, and A. Evans, "Low Energy Delayed-Neutron Spectra by Time-of-Flight," Bull. Am. Phys. Soc. 27, 498 (1982). 


\section{APPENDIX B INDIVIDUAL PRECURSOR CONTRIBUTIONS}

In Section I we identified the major contributors at high energies (Figs. $4 \mathrm{a}$ and $4 \mathrm{~b}$, where arsenic, bromine, rubidium, and iodine isotopes are explicitly noted). In this appendix more detail is provided; specifically, for ${ }^{235} \mathrm{U},{ }^{238} \mathrm{U},{ }^{232} \mathrm{Th}$, and ${ }^{239} \mathrm{Pu}$ fast fission, the per cent contribution of each precursor to the total overall energy and to the total value above $4 \mathrm{MeV}$ is listed for $\sim 0$, $1.0,5.0,10.0$, and $30.0 \mathrm{~s}$. Only contributions $>0.01 \%$ are included. (Table B-I lists precursors having energies greater than $2,3,4,5,6,7$, and $8 \mathrm{MeV}$, but not their actual contribution to delayed neutrons.) Aggregate totals were included in Section IV.

Tables B-II through B-IX are intended to serve as a guide in the determination of the probable importance to calculations of future precursor experiments. It is important for the user to realize that the listed contributions above $4 \mathrm{MeV}$ are based entirely on fission-product yields, emission probabilities, and delayed neutron spectrum models. Any single value could easily be in error by an order of magnitude; and, if so, all other relative contributions would change. Thus, a listed small contribution above $4 \mathrm{MeV}$ should not discourage a possible measurement. 
TABLE B-I

\section{PRECURSORS HAVING PROBABLE DELAYED NEUTRON ENERGIES}

ABOVE NOTED VALUES

\begin{tabular}{|c|c|c|c|c|c|c|c|c|c|}
\hline $\begin{array}{l}2.0 \\
\text { Nucl }\end{array}$ & $\begin{array}{l}\mathrm{MeV} \\
\text { lide }\end{array}$ & $\begin{array}{l}3.0 \\
\text { Nucl }\end{array}$ & $\begin{array}{l}\mathrm{MeV} \\
\text { Iice }\end{array}$ & $\begin{array}{l}4.0 \\
\text { Nucl }\end{array}$ & $\begin{array}{l}\mathrm{MeV} \\
\text { lide }\end{array}$ & $\begin{array}{l}5.0 \mathrm{MeV} \\
\text { Nuclide }\end{array}$ & $\begin{array}{l}6.0 \mathrm{MeV} \\
\text { Nuclide }\end{array}$ & $\begin{array}{l}7.0 \mathrm{MeV} \\
\text { Nuclide }\end{array}$ & $\begin{array}{l}8.0 \mathrm{MeV} \\
\text { Nuclide }\end{array}$ \\
\hline $\mathrm{CO}-$ & $72 g$ & $\mathrm{CO}-$ & $72 \mathrm{~g}$ & $\mathrm{CO}^{-}$ & $72 \mathrm{~g}$ & $\mathrm{Co}-72 \mathrm{~g}$ & $\mathrm{Co}-72 \mathrm{~g}$ & $\mathrm{Co}-72 \mathrm{~g}$ & $\mathrm{Co}-7$ \\
\hline $\mathrm{CO}^{-}$ & $73 g$ & $\mathrm{Co}-$ & $73 g$ & $\mathrm{CO}^{-}$ & $73 \mathrm{~g}$ & $\mathrm{Co}-73 \mathrm{~g}$ & $\mathrm{Co}-73 \mathrm{~g}$ & $\mathrm{Co}-73 \mathrm{~g}$ & $\mathrm{CO}-7$ \\
\hline $\mathrm{Co}-$ & $74 \mathrm{~g}$ & $\mathrm{CO}-$ & $74 \mathrm{~g}$ & $\mathrm{CO}-$ & $74 \mathrm{~g}$ & $\mathrm{CO}-74 \mathrm{~g}$ & $\mathrm{Co}-74 \mathrm{~g}$ & $\mathrm{Co}-74 \mathrm{~g}$ & $\mathrm{Co}-$ \\
\hline $\mathrm{Co}-$ & $7.5 \mathrm{~g}$ & $\mathrm{Co}-$ & $75 \mathrm{~g}$ & $\mathrm{Co}-$ & $75 \mathrm{~g}$ & $\mathrm{Co}-75 \mathrm{~g}$ & $\mathrm{Co}-75 \mathrm{~g}$ & $\mathrm{Co}-75 \mathrm{~g}$ & $\mathrm{Cu}-$ \\
\hline $\mathrm{Ni}-$ & $75 g$ & $\mathrm{Cu}-$ & $75 \mathrm{~g}$ & $\mathrm{Ni}-$ & $77 \mathrm{~g}$ & $\mathrm{Cu}-77 \mathrm{~g}$ & $\mathrm{Cu}-78 \mathrm{~g}$ & $\mathrm{Cu}-79 \mathrm{~g}$ & $\mathrm{Cu}-$ \\
\hline $\mathrm{Cu}-$ & $75 \mathrm{~g}$ & $\mathrm{Ni}-$ & $76 \mathrm{~g}$ & $\mathrm{Cu}-$ & $\because 7 \mathrm{~g}$ & $\mathrm{Ni}-78 \mathrm{~g}$ & $\mathrm{Cu}-79 \mathrm{~g}$ & $\mathrm{Cu}-80 \mathrm{~g}$ & $2 n-$ \\
\hline $\mathrm{Ni}-$ & $76 \mathrm{~g}$ & $\mathrm{Cu}-$ & $76 \mathrm{~g}$ & $\mathrm{Ni}-$ & $78 \mathrm{~g}$ & $\mathrm{Cu}-78 \mathrm{~g}$ & $\mathrm{Cu}-80 \mathrm{~g}$ & $\mathrm{Cu}-81 \mathrm{~g}$ & $\mathrm{Ga}-\varepsilon$ \\
\hline $\mathrm{Cu}-$ & $76 \mathrm{~g}$ & $\mathrm{Ni}-$ & $77 \mathrm{~g}$ & $\mathrm{Cu}-$ & $78 \mathrm{~g}$ & $\mathrm{Cu}-79 \mathrm{~g}$ & $\mathrm{Cu}-81 \mathrm{~g}$ & $2 n-82 g$ & $\mathrm{Ga}-8$ \\
\hline $\mathrm{Ni}-$ & $77 \mathrm{~g}$ & $\mathrm{Cu}-$ & $77 \mathrm{~g}$ & $\mathrm{Cu}-$ & $79 \mathrm{~g}$ & $\mathrm{Cu}-80 \mathrm{~g}$ & $2 n-82 g$ & $2 n-33 g$ & $\mathrm{Ga}-85$ \\
\hline $\mathrm{Cu}-$ & $77 \mathrm{~g}$ & $\mathrm{Ni}-$ & $78 \mathrm{~g}$ & $\mathrm{Cu}-$ & $80 \mathrm{~g}$ & $\mathrm{Cu}-81 \mathrm{~g}$ & $2 n-83 g$ & $\mathrm{Ga}-83 \mathrm{~g}$ & As- 87 \\
\hline $\mathrm{Ni}-$ & $78 \mathrm{~g}$ & $\mathrm{Cu}-$ & $78 \mathrm{~g}$ & $\mathrm{Cu}-$ & $81 \mathrm{~g}$ & $2 n-81 g$ & $\mathrm{Ga}-83 \mathrm{~g}$ & $\mathrm{Ga}-84 \mathrm{~g}$ & $\mathrm{Ge}-8$ \\
\hline $\mathrm{Cu}-$ & $78 \mathrm{~g}$ & $\mathrm{Cu}-$ & $79 g$ & $\mathrm{Zn}-$ & $81 \mathrm{~g}$ & $\mathrm{Zn}-82 \mathrm{~g}$ & $\mathrm{Ga}-84 \mathrm{~g}$ & $\mathrm{Ga}-85 \mathrm{~g}$ & As $=8$ \\
\hline $\mathrm{Cu}-$ & $79 \mathrm{~g}$ & $\mathrm{Cu}-$ & $80 \mathrm{~g}$ & $2 n-$ & $82 \mathrm{~g}$ & $\mathrm{Ga}-82 \mathrm{~g}$ & $\mathrm{Ga}-85 \mathrm{~g}$ & $A s-86 \mathrm{~g}$ & As -8 \\
\hline $2 n-$ & $79 \mathrm{~g}$ & $\mathrm{Cu}-$ & $81 \mathrm{~g}$ & $\mathrm{Ga}-$ & $82 \mathrm{~g}$ & $2 n-83 g$ & $\mathrm{Ge}-85 \mathrm{~g}$ & $\mathrm{Ge}-87 \mathrm{~g}$ & As -90 \\
\hline $\mathrm{Cu}-$ & $80 \mathrm{~g}$ & $2 n-$ & $81 \mathrm{~g}$ & $2 n-$ & 839 & $\mathrm{Ga}-83 \mathrm{~g}$ & $\mathrm{Ge}-86 \mathrm{~g}$ & As- 879 & $\mathrm{Br}-92$ \\
\hline $2 n-$ & $80 \mathrm{~g}$ & $\mathrm{Ga}-$ & $81 \mathrm{~g}$ & $\mathrm{Ga}-$ & $83 g$ & $\mathrm{Ga}-84 \mathrm{~g}$ & $A s-B 6 g$ & $\mathrm{Ge}-88 \mathrm{~g}$ & Br- 9 \\
\hline Ga- & $80 \mathrm{~g}$ & $2 n-$ & $82 \mathrm{~g}$ & Ga- & 849 & $G a-85 g$ & $\mathrm{Ge}-87 \mathrm{~g}$ & $A s-88 g$ & $\mathrm{Br}-$ \\
\hline $\mathrm{Cu}-$ & $81 \mathrm{~g}$ & $\mathrm{Ga}-$ & $82 \mathrm{~g}$ & $\mathrm{Ge}-$ & $84 \mathrm{~g}$ & $\mathrm{Ge}-85 \mathrm{~g}$ & $A s-87 g$ & $A s-89 \mathrm{~g}$ & $\mathrm{Br}-95$ \\
\hline $\mathrm{Zn}-$ & $81 \mathrm{~g}$ & $2 n-$ & 839 & $\mathrm{Ga}-$ & $85 \mathrm{~g}$ & $\mathrm{Ge}-86 \mathrm{~g}$ & $\mathrm{Ge}-88 \mathrm{~g}$ & $A s-90 \mathrm{~g}$ & $\mathrm{Br}-96$ \\
\hline $\mathrm{Ga}-$ & $81 \mathrm{~g}$ & $\mathrm{Ga}-$ & $83 g$ & $\mathrm{Ge}-$ & $85 \mathrm{~g}$ & As- $86 \mathrm{~g}$ & $A s-8.8 \mathrm{~g}$ & $\mathrm{Se}-91 \mathrm{~g}$ & $\mathrm{Rb}-101$ \\
\hline $2 n-$ & $82 \mathrm{~g}$ & $\mathrm{Ga}-$ & 849 & As- & $85 \mathrm{~g}$ & $\mathrm{Ge}-87 \mathrm{~g}$ & $A s-89 \mathrm{~g}$ & $\mathrm{Br}-91 \mathrm{~g}$ & $Y-107$ \\
\hline Ga- & $82 \mathrm{~g}$ & $\mathrm{Ge}-$ & $84 \mathrm{~g}$ & $\mathrm{Ge}-$ & $86 \mathrm{~g}$ & As $-87 \mathrm{~g}$ & As- $90 \mathrm{~g}$ & $\mathrm{Br}-92 \mathrm{~g}$ & $\mathrm{Cd}-132$ \\
\hline $2 n-$ & $83 g$ & Ga- & $85 g$ & As- & $86 \mathrm{~g}$ & $\mathrm{Ge}-88 \mathrm{~g}$ & $\mathrm{Se}-90 \mathrm{~g}$ & $\mathrm{Se}-93 \mathrm{~g}$ & In-133 \\
\hline $\mathrm{Ga}-$ & 839 & $\mathrm{Ge}-$ & $85 \mathrm{~g}$ & $\mathrm{Ge}-$ & $87 \mathrm{~g}$ & $A s-88 g$ & $\mathrm{Se}-91 \mathrm{~g}$ & $\mathrm{Br}-93 \mathrm{~g}$ & In -134 \\
\hline Ga- & $84 \mathrm{~g}$ & As - & $85 \mathrm{~g}$ & As- & 879 & $A s-89 g$ & $\mathrm{Br}-9 \mathrm{lg}$ & $\mathrm{Br}-94 \mathrm{~g}$ & --- \\
\hline Ge- & $84 \mathrm{~g}$ & $\mathrm{Ge}-$ & $86 \mathrm{~g}$ & $\mathrm{Ge}-$ & $88 \mathrm{~g}$ & $\mathrm{Se}-89 \mathrm{~g}$ & $\mathrm{Se}-92 \mathrm{~g}$ & $\mathrm{Br}-95 \mathrm{~g}$ & -- \\
\hline $\mathrm{Ga}-$ & $85 \mathrm{~g}$ & As - & $86 \mathrm{~g}$ & As- & $88 \mathrm{~g}$ & As- $90 \mathrm{~g}$ & $\mathrm{Br}-92 \mathrm{~g}$ & $\mathrm{Br}-96 \mathrm{~g}$ & --- \\
\hline $\mathrm{Ge}-$ & $85 \mathrm{~g}$ & Ge- & $87 \mathrm{~g}$ & As- & $89 \mathrm{~g}$ & $\mathrm{Se}-90 \mathrm{~g}$ & $\mathrm{Se}-93 \mathrm{~g}$ & $R b-99 g$ & $-\cdots$ \\
\hline As - & $85 \mathrm{~g}$ & As- & $87 \mathrm{~g}$ & $\mathrm{Se}-$ & $89 \mathrm{~g}$ & $\mathrm{Se}-91 \mathrm{~g}$ & $\mathrm{Br}-93 \mathrm{~g}$ & $\mathrm{Rb}-1 \mathrm{COg}$ & $\cdots$ \\
\hline $\mathrm{Ge}-$ & $86 \mathrm{~g}$ & $\mathrm{Ge}-$ & $88 \mathrm{~g}$ & As- & $90 \mathrm{~g}$ & $\mathrm{Br}-91 \mathrm{~g}$ & $\mathrm{Br}-94 \mathrm{~g}$ & $\mathrm{Rb}-101 \mathrm{~g}$ & --- \\
\hline AS- & $86 \mathrm{~g}$ & As - & $88 \mathrm{~g}$ & $\mathrm{Se}-$ & $90 \mathrm{~g}$ & $\mathrm{Se}-92 \mathrm{~g}$ & $\mathrm{Br}-95 \mathrm{~g}$ & $Y-106 \mathrm{~g}$ & --- \\
\hline $\mathrm{Ge}-$ & $87 \mathrm{~g}$ & $\mathrm{Se}-$ & $88 \mathrm{~g}$ & $\mathrm{Br}-$ & $90 \mathrm{~g}$ & $\mathrm{Br}-92 \mathrm{~g}$ & $\mathrm{Br}-96 \mathrm{~g}$ & $Y-107 \mathrm{~g}$ & --- \\
\hline As - & $87 g$ & As- & 899 & $\mathrm{Se}-$ & $91 \mathrm{~g}$ & $\mathrm{Se}-93 \mathrm{~g}$ & $R b-97 g$ & $\mathrm{Tc}-117 \mathrm{~g}$ & --- \\
\hline $\mathrm{Ge}-$ & $88 \mathrm{~g}$ & $\mathrm{Se}-$ & $89 \mathrm{~g}$ & $\mathrm{Br}-$ & $91 \mathrm{~g}$ & $\mathrm{Br}-93 \mathrm{~g}$ & $\mathrm{Rb}-98 \mathrm{~g}$ & $\mathrm{Rh}-123 \mathrm{~g}$ & -- \\
\hline As- & $88 \mathrm{~g}$ & $\mathrm{Br}-$ & $89 \mathrm{~g}$ & $\mathrm{Se}-$ & 929 & $\mathrm{Br}-94 \mathrm{~g}$ & $R b-99 g$ & $\mathrm{Cd}-132 \mathrm{~g}$ & --- \\
\hline $\mathrm{Se}-$ & $88 \mathrm{~g}$ & As - & $90 \mathrm{~g}$ & $\mathrm{Br}-$ & $92 \mathrm{~g}$ & $\mathrm{Br}-95 \mathrm{~g}$ & $\mathrm{Rb}-100 \mathrm{~g}$ & In $-133 g$ & $\ldots$ \\
\hline As- & E9g & $\mathrm{Se}-$ & $90 \mathrm{~g}$ & $\mathrm{Se}-$ & $93 \mathrm{~g}$ & $\mathrm{Br}-96 \mathrm{~g}$ & $R b-101 \mathrm{~g}$ & $\mathrm{In}-134 \mathrm{~g}$ & $\cdots$ \\
\hline $\mathrm{Se}-$ & $89 \mathrm{~g}$ & $\mathrm{Br}-$ & $90 \mathrm{~g}$ & $\mathrm{Br}-$ & $93 \mathrm{~g}$ & $R b-96 g$ & $s r-103 g$ & $S b-138 g$ & --- \\
\hline $\mathrm{Br}-$ & $89 \mathrm{~g}$ & Se- & $91 \mathrm{~g}$ & $\mathrm{Br}-$ & $94 \mathrm{~g}$ & $\mathrm{Kr}-97 \mathrm{~g}$ & $S r-104 \mathrm{~g}$ & $\mathrm{Sb}-139 \mathrm{~g}$ & --- \\
\hline As - & $90 \mathrm{~g}$ & $\mathrm{Br}-$ & $91 \mathrm{~g}$ & $\mathrm{Kr}-$ & $94 \mathrm{~g}$ & $\mathrm{Rb}-97 \mathrm{~g}$ & $Y-105 g$ & $I-143 g$ & --- \\
\hline $\mathrm{Se}^{-}$ & $90 \mathrm{~g}$ & $\mathrm{Se}-$ & $92 \mathrm{~g}$ & $\mathrm{Br}-$ & $95 \mathrm{~g}$ & $\mathrm{Kr}-98 \mathrm{~g}$ & $Y-106 g$ & $\mathrm{Cs}-149 \mathrm{~g}$ & --- \\
\hline Br- & $90 \mathrm{~g}$ & $\mathrm{Br}-$ & $92 \mathrm{~g}$ & $\mathrm{Kr}-$ & $95 \mathrm{~g}$ & $\mathrm{Rb}-9 \mathrm{Bg}$ & $\mathrm{Y}-107 \mathrm{~g}$ & --- & --- \\
\hline $\mathrm{Se}-$ & 919 & $\mathrm{Se}-$ & $93 \mathrm{~g}$ & $R b-$ & $95 \mathrm{~g}$ & $\mathrm{Rb}-99 \mathrm{~g}$ & $\mathrm{Nb}-111 \mathrm{~g}$ & --- & --- \\
\hline $\mathrm{Br}-$ & $91 \mathrm{~g}$ & $\mathrm{Br}-$ & 939 & $\mathrm{Br}-$ & $96 \mathrm{~g}$ & $\mathrm{Rb}-100 \mathrm{~g}$ & $\mathrm{Tc}-116 \mathrm{~g}$ & --- & --- \\
\hline Se- & $92 \mathrm{~g}$ & $\mathrm{Br}-$ & $94 \mathrm{~g}$ & $\mathrm{Kr}-$ & $96 \mathrm{~g}$ & $R b-201 g$ & $\mathrm{Tc}-117 \mathrm{~g}$ & $-\cdots$ & --- \\
\hline $\mathrm{Br}-$ & $92 \mathrm{~g}$ & $\mathrm{Kr}-$ & $94 \mathrm{~g}$ & $\mathrm{Rb}-$ & $96 \mathrm{~g}$ & $S r-103 g$ & $\mathrm{Rh}-121 \mathrm{~g}$ & --- & -- \\
\hline Se- & $93 \mathrm{~g}$ & $\mathrm{Rb}-$ & $94 \mathrm{~g}$ & $\mathrm{Kr}-$ & $97 \mathrm{~g}$ & $S r-104 g$ & $\mathrm{Rh}-122 \mathrm{~g}$ & --- & --- \\
\hline $\mathrm{Br}-$ & $93 \mathrm{~g}$ & $\mathrm{Br}-$ & $95 \mathrm{~g}$ & $\mathrm{Rb}-$ & 979 & $Y-104 \mathrm{~g}$ & $\mathrm{Rh}-123 \mathrm{~g}$ & --- & -- \\
\hline
\end{tabular}

Continued 
Table B-I (Cont.)

\begin{tabular}{|c|c|c|c|c|c|c|}
\hline $\begin{array}{l}2.0 \mathrm{MeV} \\
\text { Nuclide }\end{array}$ & $\begin{array}{l}3.0 \mathrm{MeV} \\
\text { Nuclide }\end{array}$ & $\begin{array}{l}4.0 \mathrm{MeV} \\
\text { Nuclide }\end{array}$ & $\begin{array}{l}5.0 \mathrm{MeV} \\
\text { Nuclide }\end{array}$ & $\begin{array}{l}6.0 \mathrm{MeV} \\
\text { Nuclide }\end{array}$ & $\begin{array}{l}7.0 \mathrm{MeV} \\
\text { Nuclide }\end{array}$ & $\begin{array}{l}8.0 \mathrm{M} \\
\text { Nucli }\end{array}$ \\
\hline$K r-93 g$ & $\mathrm{Kr}-95 \mathrm{~g}$ & $\mathrm{Kr}-98 \mathrm{~g}$ & $Y-105 g$ & $\mathrm{Cd}-132 \mathrm{~g}$ & --- & \\
\hline$R b-93 y$ & $\mathrm{Rb}-95 \mathrm{~g}$ & $\mathrm{Rb}-98 \mathrm{~g}$ & $Y-106 g$ & $\mathrm{In}-1.33 \mathrm{~g}$ & --- & \\
\hline$B r-94 g$ & $\mathrm{Br}-96 \mathrm{~g}$ & $R b-99 g$ & $Y-107 g$ & $\mathrm{In}-134 \mathrm{~g}$ & --- & \\
\hline $\mathrm{Kr}-94 \mathrm{~g}$ & $\mathrm{Kr}-96 \mathrm{~g}$ & $\mathrm{Rb}-100 \mathrm{~g}$ & $2 r-109 g$ & $S b-13 B g$ & -- & \\
\hline $\mathrm{Rb}-94 \mathrm{~g}$ & $R b-96 g$ & $\mathrm{Rb}-101 \mathrm{~g}$ & $\mathrm{Nb}-109 \mathrm{~g}$ & $\mathrm{sb}-139 \mathrm{~g}$ & --- & \\
\hline$B r-95 g$ & $\mathrm{Kr}-97 \mathrm{~g}$ & $Y-101 g$ & $\mathrm{Nb}-110 \mathrm{~g}$ & I $-142 \mathrm{~g}$ & -- & \\
\hline $\mathrm{Kr}-95 \mathrm{~g}$ & $\mathrm{Rb}-97 \mathrm{~g}$ & $s r-103 g$ & $\mathrm{Nb}-111 \mathrm{~g}$ & $I-143 g$ & --- & \\
\hline $\mathrm{Rb}-95 \mathrm{~g}$ & $\mathrm{Kr}-98 \mathrm{~g}$ & $Y-103 g$ & $\mathrm{Tc}-115 \mathrm{~g}$ & $\mathrm{I}-144 \mathrm{~g}$ & --- & \\
\hline $\mathrm{Br}-96 \mathrm{~g}$ & $\mathrm{Rb}-9 \mathrm{Bg}$ & $S r-104 \mathrm{~g}$ & $\mathrm{Tc}-116 \mathrm{~g}$ & $I-145 g$ & --- & \\
\hline$K r-96 g$ & $R b-99 g$ & $Y-104 \mathrm{~g}$ & $\mathrm{Tc}-117 \mathrm{~g}$ & $\mathrm{Cs}-148 \mathrm{~g}$ & -- & \\
\hline$R b-96 g$ & $Y-99 g$ & $Y-105 g$ & $\mathrm{Ru}-120 \mathrm{~g}$ & $\mathrm{Cs}-149 \mathrm{~g}$ & --- & \\
\hline $\mathrm{Kr}-97 \mathrm{~g}$ & $\mathrm{Rb}-100 \mathrm{~g}$ & $Y-106 g$ & $\mathrm{Rh}-121 \mathrm{~g}$ & $\mathrm{Cs}-150 \mathrm{~g}$ & --- & \\
\hline$R b-97 g$ & $\mathrm{Rb}-101 \mathrm{~g}$ & $\mathrm{Y}-107 \mathrm{~g}$ & $\mathrm{Rh}-122 \mathrm{~g}$ & $L a-155 g$ & --- & \\
\hline$K r-98 g$ & $\mathrm{Sr}-101 \mathrm{~g}$ & $\mathrm{Nb}-107 \mathrm{~g}$ & $\mathrm{Rh}-123 \mathrm{~g}$ & $\cdots$ & -- & \\
\hline$R b-98 g$ & $Y-101 g$ & $\mathrm{Zr}-108 \mathrm{~g}$ & $\mathrm{Ag}-127 \mathrm{~g}$ & --- & --- & \\
\hline$Y-98 g$ & $s r-102 g$ & $\mathrm{Nb}-108 \mathrm{~g}$ & $\mathrm{Ag}-128 \mathrm{~g}$ & --- & --- & \\
\hline$R b-99 g$ & $Y-102 g$ & $\mathrm{zr}-109 \mathrm{~g}$ & $c d-131 \mathrm{~g}$ & --- & --- & \\
\hline$S r-99 g$ & $S r-103 g$ & $\mathrm{Nb}-109 \mathrm{~g}$ & $\mathrm{Cd}-132 \mathrm{~g}$ & --- & --- & \\
\hline$y-99 g$ & $Y-103 g$ & $\mathrm{Nb}-110 \mathrm{~g}$ & In $-132 \mathrm{~g}$ & --- & --- & \\
\hline $\mathrm{Rb}-100 \mathrm{~g}$ & $S r-104 \mathrm{~g}$ & $\mathrm{Nb}-111 \mathrm{~g}$ & In-133g & $-\cdots$ & --- & \\
\hline$S r-100 g$ & $Y-104 g$ & $\mathrm{Mo}-113 \mathrm{~g}$ & In $-134 \mathrm{~g}$ & --- & --- & \\
\hline$Y-100 g$ & $Y-105 g$ & $\mathrm{Tc}-113 \mathrm{~g}$ & $S n-135 g$ & --- & --- & \\
\hline $\mathrm{Rb}-101 \mathrm{~g}$ & $Y-106 g$ & $\mathrm{Tc}-114 \mathrm{~g}$ & $\mathrm{sn}-136 \mathrm{~g}$ & --- & $-\cdots$ & \\
\hline$s r-101 g$ & $Y-107 g$ & $\mathrm{Tc}-115 \mathrm{~g}$ & $\mathrm{sb}-137 \mathrm{~g}$ & -- & --- & \\
\hline$y-101 g$ & $2 x-107 g$ & $\mathrm{Tc}-116 \mathrm{~g}$ & $\mathrm{Sb}-138 \mathrm{~g}$ & -- & --- & \\
\hline$S r-102 g$ & $\mathrm{Nb}-107 \mathrm{~g}$ & $\mathrm{Tc}-117 \mathrm{~g}$ & $\mathrm{sb}-139 \mathrm{~g}$ & --- & --- & --- \\
\hline$Y-102 g$ & $2 x-108 g$ & $R u-119 g$ & $\mathrm{Te}-140 \mathrm{~g}$ & --- & --- & \\
\hline$S x-103 g$ & $\mathrm{Nb}-108 \mathrm{~g}$ & $\mathrm{Rh}-119 \mathrm{~g}$ & $\mathrm{Te}-141 \mathrm{~g}$ & --- & $-\cdots$ & --- \\
\hline$y-103 g$ & $z r-109 g$ & $\mathrm{Ru}-120 \mathrm{~g}$ & $I-141 g$ & --- & --- & --- \\
\hline$S r-104 g$ & $\mathrm{Nb}-109 \mathrm{~g}$ & $\mathrm{Rh}-120 \mathrm{~g}$ & $\mathrm{Te}-142 \mathrm{~g}$ & -- & $-\cdots$ & --- \\
\hline$Y-104 g$ & $\mathrm{Nb}-110 \mathrm{~g}$ & $\mathrm{Rh}-121 \mathrm{~g}$ & $\mathrm{I}-142 \mathrm{~g}$ & $-\cdots$ & --- & -- \\
\hline$Y-105 g$ & $\mathrm{Nb}-111 \mathrm{~g}$ & $\mathrm{Rh}-122 \mathrm{~g}$ & $I-143 g$ & --- & --- & $\cdots$ \\
\hline$z x-105 g$ & $\mathrm{Tc}-11 \mathrm{lg}$ & $\mathrm{Rh}-123 \mathrm{~g}$ & $I-144 \mathrm{~g}$ & --- & --- & --- \\
\hline $\mathrm{Nb}-105 \mathrm{~g}$ & $\mathrm{Tc}-112 \mathrm{~g}$ & $\mathrm{Ag}-125 \mathrm{~g}$ & $I-145 g$ & --- & --- & -- \\
\hline$Y-106 g$ & $\mathrm{Mo}-113 \mathrm{~g}$ & $\mathrm{Pd}-126 \mathrm{~g}$ & $\mathrm{Xe}-147 \mathrm{~g}$ & --- & --- & --- \\
\hline $2 x-106 g$ & $\mathrm{Tc}-113 \mathrm{~g}$ & $\mathrm{Ag}-126 \mathrm{~g}$ & $\mathrm{Cs}-14 \mathrm{Bg}$ & --- & --- & -- \\
\hline $\mathrm{Nb}-106 \mathrm{~g}$ & $\mathrm{TC}-114 \mathrm{~g}$ & $\mathrm{Ag}-127 \mathrm{~g}$ & $\mathrm{Cs}-149 \mathrm{~g}$ & --- & --- & -. \\
\hline$Y-107 g$ & $\mathrm{TC}-115 \mathrm{~J}$ & $\mathrm{Ag}-128 \mathrm{~g}$ & $\mathrm{Cs}-150 \mathrm{~g}$ & --- & -- & $\cdots$ \\
\hline $\mathrm{Zr}-107 \mathrm{~g}$ & $\mathrm{Tc}-116 \mathrm{~g}$ & $\mathrm{~cd}-131 \mathrm{~g}$ & $\mathrm{La}-154 \mathrm{~g}$ & -- & --- & --- \\
\hline $\mathrm{Nb}-107 \mathrm{~g}$ & $\mathrm{Tc}-117 \mathrm{~g}$ & $\mathrm{Cd}-132 \mathrm{~g}$ & $\mathrm{La}-155 \mathrm{~g}$ & --- & --- & -- \\
\hline $\mathrm{zr}-108 \mathrm{~g}$ & $\mathrm{Ru}-117 \mathrm{~g}$ & $\mathrm{In}-132 \mathrm{~g}$ & Pr $-159 \mathrm{~g}$ & --- & $-\cdots$ & --- \\
\hline $\mathrm{Nb}-108 \mathrm{~g}$ & $\mathrm{Rh}-117 \mathrm{~g}$ & $\mathrm{In}-133 \mathrm{~g}$ & -- & --- & --- & --- \\
\hline $2 x-109 g$ & $\mathrm{ku}-118 \mathrm{~g}$ & $\mathrm{In}-134 \mathrm{~g}$ & --- & --- & --- & --- \\
\hline $\mathrm{Nb}-109 \mathrm{~g}$ & $\mathrm{Rh}-118 \mathrm{~g}$ & $s n-135 g$ & --- & --- & --- & -- \\
\hline $\mathrm{Nb}-110 \mathrm{~g}$ & $R u-119 g$ & $s b-135 g$ & --- & --- & --- & -- \\
\hline $\mathrm{MO}-110 \mathrm{~g}$ & $\mathrm{Rh}-119 \mathrm{~g}$ & $\mathrm{sn}-136 \mathrm{~g}$ & --- & --- & --- & --- \\
\hline $\mathrm{Nb}-111 \mathrm{~g}$ & $R u-120 g$ & $s b-136 g$ & --- & --- & --- & -- \\
\hline Mo-111g & $\mathrm{Rh}-120 \mathrm{~g}$ & $S b-137 g$ & --- & --- & --- & --- \\
\hline
\end{tabular}

Continued 
Table B-I (Cont.)

\begin{tabular}{|c|c|c|c|c|c|c|}
\hline $\begin{array}{l}2.0 \mathrm{MeV} \\
\text { Nuclide }\end{array}$ & $\begin{array}{l}3.0 \mathrm{MeV} \\
\text { Nuclide }\end{array}$ & $\begin{array}{l}4.0 \mathrm{MeV} \\
\text { Nuclide }\end{array}$ & $\begin{array}{l}5.0 \mathrm{MeV} \\
\text { Nuclide }\end{array}$ & $\begin{array}{l}6.0 \mathrm{MeV} \\
\text { Nuclide }\end{array}$ & $\begin{array}{l}7.0 \mathrm{MeV} \\
\text { Nuclide }\end{array}$ & $\begin{array}{l}\text { 8.0 MeV } \\
\text { Nuclide }\end{array}$ \\
\hline $\mathrm{Tc}-111 \mathrm{~g}$ & $\mathrm{Rh}-121 \mathrm{~g}$ & $s b-138 g$ & --- & -- & $-\infty$ & -- \\
\hline $\mathrm{Mo}-112 \mathrm{~g}$ & $\mathrm{Rh}-122 \mathrm{~g}$ & $S b-139 g$ & --- & -- & --- & --- \\
\hline $\mathrm{TC}-112 \mathrm{~g}$ & $\mathrm{Rh}-123 \mathrm{~g}$ & $\mathrm{Te}-139 \mathrm{~g}$ & --- & -- & --- & --- \\
\hline Mo-113g & $\mathrm{Pd}-124 \mathrm{~g}$ & $\mathrm{Te}-140 \mathrm{~g}$ & --- & -- & --- & --- \\
\hline $\mathrm{Tc}-113 \mathrm{~g}$ & $\mathrm{Ag}-124 \mathrm{~g}$ & $\mathrm{I}-140 \mathrm{~g}$ & --- & --- & $\cdots$ & $-\cdots$ \\
\hline $\mathrm{Tc}-114 \mathrm{~g}$ & $\mathrm{Pd}-125 \mathrm{~g}$ & $\mathrm{Te}-141 \mathrm{~g}$ & --- & -- & --- & --- \\
\hline $\mathrm{Tc}-115 \mathrm{~g}$ & $\mathrm{Ag}-125 \mathrm{~g}$ & $I-141 \mathrm{~g}$ & --- & --- & -- & --- \\
\hline $\mathrm{Tc}-116 \mathrm{~g}$ & $\mathrm{Pd}-126 \mathrm{~g}$ & $\mathrm{Te}-142 \mathrm{~g}$ & --- & -- & $\ldots$ & --- \\
\hline Ru-116g & $\mathrm{Ag}-126 \mathrm{z}$ & $I-142 g$ & -- & --- & --- & -- \\
\hline $\mathrm{Tc}-117 \mathrm{~g}$ & $\mathrm{Ag}-127 \mathrm{~g}$ & $I-143 g$ & -- & --- & --- & --- \\
\hline$R u-117 g$ & $\mathrm{Ag}-128 \mathrm{~g}$ & $\mathrm{I}-144 \mathrm{~g}$ & $-\cdots$ & --- & $\cdots$ & $\cdots$ \\
\hline $\mathrm{Rh}-117 \mathrm{~g}$ & $\mathrm{~cd}-13 \mathrm{lg}$ & $I-145 g$ & --- & -- & --- & --- \\
\hline$R u-118 g$ & $\mathrm{In}-131 \mathrm{~g}$ & $\mathrm{Xe}-145 \mathrm{~g}$ & $-\cdots$ & --- & --- & --- \\
\hline $\mathrm{Rh}-118 \mathrm{~g}$ & $c d-132 \mathrm{~g}$ & $\mathrm{Xe}-146 \mathrm{~g}$ & -- & --- & --- & --- \\
\hline $\mathrm{Ru}-119 \mathrm{~g}$ & $\mathrm{In}-132 \mathrm{~g}$ & $\mathrm{Cs}-146 \mathrm{~g}$ & --- & --- & -- & --- \\
\hline $\mathrm{Rh}-119 \mathrm{~g}$ & $\mathrm{In}-133 \mathrm{~g}$ & $x e-147 g$ & --- & -- & --- & --- \\
\hline $\mathrm{Ru}-120 \mathrm{~g}$ & $I n-134 g$ & $\mathrm{Cs}-147 \mathrm{~g}$ & $-\cdots$ & --- & --- & --- \\
\hline $\mathrm{Rh}-120 \mathrm{~g}$ & $\mathrm{Sn}-134 \mathrm{~g}$ & $\mathrm{Cs}-148 \mathrm{~g}$ & --- & $\cdots$ & --- & --- \\
\hline $\mathrm{Rh}-12 \mathrm{lg}$ & $5 n-135 g$ & $\mathrm{Cs}-149 \mathrm{~g}$ & --- & --- & --- & --- \\
\hline $\mathrm{Rh}-122 \mathrm{~g}$ & $S b-135 g$ & $\mathrm{Cs}-150 \mathrm{~g}$ & --- & --- & --- & --- \\
\hline $\mathrm{Rh}-123 \mathrm{~g}$ & $s n-136 g$ & $\mathrm{Ba}-150 \mathrm{~g}$ & --- & -- & -- & --- \\
\hline $\mathrm{Pd}-123 \mathrm{~g}$ & $s b-136 g$ & $\mathrm{La}-153 \mathrm{~g}$ & --- & --- & $\cdots$ & --- \\
\hline $\mathrm{Ag}-123 \mathrm{~g}$ & $\mathrm{sb}-137 \mathrm{~g}$ & $\mathrm{La}-154 \mathrm{~g}$ & --- & --- & --- & --- \\
\hline $\mathrm{Pd}-124 \mathrm{~g}$ & $S b-138 g$ & $\mathrm{La}-155 \mathrm{~g}$ & $-\cdots$ & -- & -- & $\ldots$ \\
\hline $\mathrm{Ag}-124 \mathrm{~g}$ & $\mathrm{Sb}-139 \mathrm{~g}$ & Pr $-158 \mathrm{~g}$ & --- & --- & --- & --- \\
\hline$P d-125 \mathrm{~g}$ & $\mathrm{Te}-139 \mathrm{~g}$ & Pr-159g & --- & -- & --- & --- \\
\hline $\mathrm{Ag}-125 \mathrm{~g}$ & I $-139 g$ & --- & --- & --- & -- & $-\cdots$ \\
\hline $\mathrm{Pd}-126 \mathrm{~g}$ & $\mathrm{Te}-140 \mathrm{~g}$ & -- & -- & $\rightarrow-$ & $-\cdots$ & -- \\
\hline $\mathrm{Ag}-126 \mathrm{~g}$ & $\mathrm{I}-140 \mathrm{~g}$ & --- & --- & --- & --- & --- \\
\hline $\mathrm{Ag}-127 \mathrm{~g}$ & $\mathrm{Te}-141 \mathrm{~g}$ & --- & --- & -- & --- & --- \\
\hline $\mathrm{Ag}-128 \mathrm{~g}$ & I $-141 \mathrm{~g}$ & $\cdots$ & --- & -- & --- & --- \\
\hline $\mathrm{In}-129 \mathrm{~g}$ & $\mathrm{Te}-142 \mathrm{~g}$ & --- & --- & --- & -- & $-\cdots$ \\
\hline $\mathrm{cd}-130 \mathrm{~g}$ & $\mathrm{I}-142 \mathrm{~g}$ & --- & --- & --- & --- & -- \\
\hline $\mathrm{In}-130 \mathrm{~g}$ & I $-143 g$ & --- & --- & --- & --- & --- \\
\hline $\mathrm{cd}-131 \mathrm{~g}$ & $\mathrm{xe}-143 \mathrm{~g}$ & --- & -- & --- & --- & --- \\
\hline $\mathrm{In}-131 \mathrm{~g}$ & $\mathrm{I}-144 \mathrm{~g}$ & --- & --- & --- & -- & -- \\
\hline $\mathrm{cd}-132 \mathrm{~g}$ & $\mathrm{Xe}-144 \mathrm{~g}$ & --- & --- & --- & --- & --- \\
\hline In $-132 \mathrm{~g}$ & $i-145 g$ & --- & --- & --- & -- & --- \\
\hline $\mathrm{In}-133 \mathrm{~g}$ & $x e-145 g$ & -- & $\cdots$ & --- & --- & $\cdots$ \\
\hline $\mathrm{In}-134 \mathrm{~g}$ & $\mathrm{Cs}-145 \mathrm{~g}$ & $-\cdots$ & -- & $\cdots$ & --- & -- \\
\hline $\mathrm{Sn}-134 \mathrm{~g}$ & $\mathrm{Xe}-146 \mathrm{~g}$ & --- & --- & --- & -- & -- \\
\hline$s n-135 g$ & $\mathrm{Cs}-146 \mathrm{~g}$ & --- & --- & --- & $-\cdots$ & --- \\
\hline$S b-135 g$ & $\mathrm{Xe}-147 \mathrm{~g}$ & --- & --- & --- & --- & --- \\
\hline$S n-136 g$ & $\mathrm{Cs}-147 \mathrm{~g}$ & -- & $-\cdots$ & --- & $-\cdots$ & --- \\
\hline $\mathrm{sb}-136 \mathrm{~g}$ & $\mathrm{Cs}-148 \mathrm{~g}$ & --- & --- & --- & --- & --- \\
\hline$S b-137 g$ & $\mathrm{Cs}-149 \mathrm{~g}$ & --- & $-\cdots$ & --- & --- & --- \\
\hline $\mathrm{Sb}-138 \mathrm{~g}$ & $\mathrm{Cs}-150 \mathrm{~g}$ & --- & $-\cdots$ & --- & --- & --- \\
\hline $\mathrm{Te}-138 \mathrm{~g}$ & $\mathrm{Ba}-150 \mathrm{~g}$ & --- & --- & $-\cdots$ & --- & --- \\
\hline$I-138 g$ & $\mathrm{Ba}-151 \mathrm{~g}$ & --- & --- & --- & $-\cdots$ & -- \\
\hline
\end{tabular}


TABLE B-I (Cont.)

$2.0 \mathrm{MeV} 3.0 \mathrm{MeV}$ Nuclide Nuclide
4.0 MeV Nuclide
$5.0 \mathrm{MeV}$ Nuclide
$6.0 \mathrm{MeV} 7.0 \mathrm{MeV}$

8.0 MeV Nuclide Nuclide Nuclide

\begin{tabular}{|c|c|c|c|c|c|c|}
\hline$S b-139 g$ & $\mathrm{La}-151 \mathrm{~g}$ & --- & --- & --- & -- & -- \\
\hline $\mathrm{Te}-139 \mathrm{~g}$ & $\mathrm{Ba}-152 \mathrm{~g}$ & --- & --- & -- & --- & --- \\
\hline I $-139 g$ & $\mathrm{La}-152 \mathrm{~g}$ & --- & -- & --- & --- & --- \\
\hline $\mathrm{Te}-140 \mathrm{~g}$ & $\mathrm{La}-153 \mathrm{~g}$ & --- & --- & --- & --- & --- \\
\hline $\mathrm{I}-140 \mathrm{~g}$ & $\mathrm{La}-154 \mathrm{~g}$ & --- & -- & --- & --- & --- \\
\hline $\mathrm{Te}-141 \mathrm{~g}$ & $\mathrm{La}-155 \mathrm{~g}$ & --- & --- & --- & --- & -- \\
\hline I $-14 \mathrm{lg}$ & $\mathrm{Ce}-156 \mathrm{~g}$ & --- & -- & --- & --- & --- \\
\hline $\mathrm{Te}-142 \mathrm{~g}$ & $\mathrm{Ce}-157 \mathrm{~g}$ & --- & --- & $-\cdots$ & -- & -- \\
\hline $\mathrm{I}-142 \mathrm{~g}$ & Pr $-157 \mathrm{~g}$ & --- & --- & --- & --- & --- \\
\hline I $-143 g$ & Pr $-1.58 \mathrm{~g}$ & --- & --- & --- & --- & --- \\
\hline$x e-143 g$ & $\operatorname{Pr}-159 \mathrm{~g}$ & -- & -- & --- & -- & -- \\
\hline $\mathrm{Cs}-143 \mathrm{~g}$ & -- & --- & --- & -- & -- & --- \\
\hline I $-144 \mathrm{~g}$ & --- & --- & --- & $-\cdots$ & --- & --- \\
\hline $\mathrm{Xe}-144 \mathrm{~g}$ & --- & --- & $-\cdots$ & --- & --- & --- \\
\hline $\mathrm{Cs}-144 \mathrm{~g}$ & --- & -- & --- & --- & --- & --- \\
\hline$I-145 g$ & -- & --- & -- & -- & --- & -- \\
\hline $\mathrm{Xe}-145 \mathrm{~g}$ & --- & -- & -- & --- & -- & --- \\
\hline $\mathrm{Cs}-145 \mathrm{~g}$ & --- & --- & --- & -- & --- & --- \\
\hline$x e-146 g$ & --- & --- & $-\cdots$ & --- & --- & -- \\
\hline $\mathrm{Cs}-146 \mathrm{~g}$ & --- & --- & --- & --- & --- & --- \\
\hline $\mathrm{Xe}-147 \mathrm{~g}$ & --- & -- & -- & --- & --- & --- \\
\hline $\mathrm{Cs}-147 \mathrm{~g}$ & -- & --- & -- & --- & --- & --- \\
\hline $\mathrm{Cs}-148 \mathrm{~g}$ & --- & --- & -- & --- & --- & --- \\
\hline $\mathrm{Cs}-149 \mathrm{~g}$ & $-\cdots$ & --- & --- & -- & --- & --- \\
\hline $\mathrm{Ba}-149 \mathrm{~g}$ & --- & --- & -- & --- & --- & --- \\
\hline $\mathrm{Cs}-150 \mathrm{~g}$ & --- & --- & --- & --- & --- & --- \\
\hline $\mathrm{Ba}-150 \mathrm{~g}$ & -- & --- & -- & --- & -- & --- \\
\hline $\mathrm{Ba}-151 \mathrm{~g}$ & --- & --- & -- & -- & -- & -- \\
\hline $\mathrm{La}-15 \mathrm{Ig}$ & --- & --- & -- & --- & --- & --- \\
\hline $\mathrm{Ba}-152 \mathrm{~g}$ & --- & --- & --- & --- & $-\sim$ & -- \\
\hline $\mathrm{La}-152 \mathrm{~g}$ & --- & --- & --- & --- & -- & -- \\
\hline $\mathrm{La}-153 \mathrm{~g}$ & --- & --- & --- & $-\cdots$ & --- & --- \\
\hline $\mathrm{La}-154 \mathrm{~g}$ & -- & $-\cdots$ & $\cdots$ & --- & --- & --- \\
\hline $\mathrm{La}-155 \mathrm{~g}$ & --- & --- & --- & --- & -- & -- \\
\hline $\mathrm{Ce}-155 \mathrm{~g}$ & --- & --- & --- & --- & --- & --- \\
\hline Pr $-155 g$ & --- & --- & --- & $-\cdots$ & $\cdots$ & -- \\
\hline $\mathrm{Ce}-156 \mathrm{~g}$ & --- & --- & $-\cdots$ & --- & --- & --- \\
\hline Pr $-156 g$ & --- & --- & $-\cdots$ & --- & -- & --- \\
\hline $\mathrm{Ce}-157 \mathrm{~g}$ & --- & --- & -- & --- & --- & --- \\
\hline $\mathrm{Pr}-157 \mathrm{~g}$ & --- & --- & -- & --- & --- & --- \\
\hline$P r-158 g$ & --- & --- & --- & --- & --- & -- \\
\hline Pr $-159 g$ & --- & --- & --- & --- & --- & --- \\
\hline $\mathrm{Nd}-161 \mathrm{~g}$ & --- & --- & -- & --- & --- & --- \\
\hline $\mathrm{Pm}-162 \mathrm{~g}$ & --- & --- & -- & --- & --- & \\
\hline
\end{tabular}




\section{TABLE B-II \\ 235U FISSION PULSE}

PER CENT CONTRIBUTION PER PRECURSOR GREATER THAN $0.01 \%$

FOR ENERGIES ABOVE $0.0 \mathrm{MeV}$

$(0.0 s)$

$(1.0 s)$

$(5.0 s)$

$(10.0 s)$

$(30.0 \mathrm{~s})$

\begin{tabular}{|c|c|c|c|c|c|c|c|c|c|c|}
\hline Nuc & Iide & 8 & Nuclide & 8 & Nuclide & 8 & Nuclide & $\%$ & Nuclide & z \\
\hline $\mathrm{Cu}-$ & $77 \mathrm{~g}$ & 0.01 & $\mathrm{Ga}-80 \mathrm{~g}$ & 0.01 & $\mathrm{Ga}-80 \mathrm{~g}$ & 0.01 & $\mathrm{Ge}-84 \mathrm{~g}$ & 0.01 & $A s-85 g$ & 0.04 \\
\hline $\mathrm{Ga}-$ & $81 \mathrm{~g}$ & 0.09 & $\mathrm{Ga}-81 \mathrm{~g}$ & 0.14 & $\mathrm{Ga}-81 \mathrm{~g}$ & 0.06 & $A s-85 g$ & 6.19 & $\mathrm{Se}-87 \mathrm{~g}$ & 0.08 \\
\hline $\mathrm{Ga}-$ & $82 \mathrm{~g}$ & 0.11 & $\mathrm{Ga}-82 \mathrm{~g}$ & 0.09 & $\mathrm{Ge}-84 \mathrm{~g}$ & 0.07 & $\mathrm{Se}-87 \mathrm{~g}$ & 0.17 & $\mathrm{Br}-87 \mathrm{~g}$ & 7.49 \\
\hline $\mathrm{Ga}-$ & 839 & 0.13 & $\mathrm{Ga}-83 \mathrm{~g}$ & 0.04 & As- $85 \mathrm{~g}$ & 12.70 & $\mathrm{Br}-87 \mathrm{~g}$ & 1.56 & $\mathrm{Br}-88 \mathrm{~g}$ & 26.69 \\
\hline Ga- & $84 \mathrm{~g}$ & 0.03 & $\mathrm{Ge}-84 \mathrm{~g}$ & 0.18 & $A s-86 \mathrm{~g}$ & 0.15 & $\mathrm{Se}-88 \mathrm{~g}$ & 0.06 & $\mathrm{Br}-89 \mathrm{~g}$ & 5.27 \\
\hline $\mathrm{Ge}-$ & $84 \mathrm{~g}$ & 0.12 & As- $84 \mathrm{~g}$ & 0.01 & $\mathrm{Se}-87 \mathrm{~g}$ & 0.12 & $\mathrm{Br}-88 \mathrm{~g}$ & 11.79 & $\mathrm{Br}-90 \mathrm{~g}$ & 0.01 \\
\hline As - & $84 \mathrm{~g}$ & 0.04 & $\mathrm{Ge}-85 \mathrm{~g}$ & 0.06 & $\mathrm{Br}-87 \mathrm{~g}$ & 0.54 & $\mathrm{Br}-89 \mathrm{~g}$ & 23.24 & $\mathrm{Rb}-92 \mathrm{~g}$ & 0.01 \\
\hline $\mathrm{Ge}-$ & $85 \mathrm{~g}$ & 0.38 & $A s-85 g$ & 12.28 & $\mathrm{Se}-88 \mathrm{~g}$ & 0.22 & $\mathrm{Br}-90 \mathrm{~g}$ & 4.85 & $\mathrm{Rb}-93 \mathrm{~g}$ & 3.09 \\
\hline As- & $85 \mathrm{~g}$ & 6.42 & $A s-86 \mathrm{~g}$ & 0.80 & $\mathrm{Br}-88 \mathrm{~g}$ & 5.31 & $\mathrm{Rb}-92 \mathrm{~g}$ & 0.05 & $\mathrm{Rb}-94 \mathrm{~g}$ & 0.45 \\
\hline $\mathrm{Ge}-$ & $86 g$ & 0.05 & As $-87 \mathrm{~g}$ & 0.70 & $\mathrm{Br}-69 \mathrm{~g}$ & 19.07 & $\mathrm{Kr}-93 \mathrm{~g}$ & 0.03 & $Y-97 g$ & 0.02 \\
\hline As - & $86 \mathrm{~g}$ & 0.66 & $\mathrm{Se}-87 \mathrm{~g}$ & 0.05 & $\mathrm{Br}-90 \mathrm{~g}$ & 12.38 & $R b-93 g$ & 6.12 & $\mathrm{Nb}-105 \mathrm{~g}$ & 0.01 \\
\hline As - & $87 \mathrm{~g}$ & 2.67 & $\mathrm{Br}-87 \mathrm{~g}$ & 0.12 & $\mathrm{Br}-91 \mathrm{~g}$ & 0.13 & $\mathrm{Rb}-94 \mathrm{~g}$ & 12.79 & $\mathrm{sb}-134 \mathrm{~g}$ & 0.07 \\
\hline $\mathrm{Se}-$ & $87 \mathrm{~g}$ & 0.02 & $\mathrm{Se}-88 \mathrm{~g}$ & 0.35 & $\mathrm{Kr}-92 \mathrm{~g}$ & 0.02 & $Y-97 g$ & 0.16 & $\mathrm{Te}-136 \mathrm{~g}$ & 3.30 \\
\hline $\mathrm{Br}-$ & $87 \mathrm{~g}$ & 0.04 & $\mathrm{Br}-88 \mathrm{~g}$ & 1.37 & $\mathrm{Rb}-92 \mathrm{~g}$ & 0.03 & $Y-98 \mathrm{~g}$ & 0.11 & $\mathrm{Te}-137 \mathrm{~g}$ & 0.10 \\
\hline As - & $88 \mathrm{~g}$ & 0.40 & $\mathrm{Se}-89 \mathrm{~g}$ & 0.82 & $\mathrm{Kr}-93 \mathrm{~g}$ & 0.15 & $Y-98 m$ & 0.02 & $\mathrm{I}-137 \mathrm{~g}$ & 46.52 \\
\hline $\mathrm{Se}-$ & $88 g$ & 0.21 & $\mathrm{Br}-89 \mathrm{~g}$ & 8.74 & $R b-93 g$ & 4.09 & $Y-99 g$ & 0.48 & $\mathrm{I}-138 \mathrm{~g}$ & 6.36 \\
\hline $\mathrm{Br}-$ & $88 \mathrm{~g}$ & 0.50 & $\mathrm{Se}-90 \mathrm{~g}$ & 0.18 & $\mathrm{Rb}-94 \mathrm{~g}$ & 16.70 & $2 r-104 g$ & 0.01 & $\mathrm{I}-139 \mathrm{~g}$ & 0.05 \\
\hline As - & $89 g$ & 0.07 & $\mathrm{Br}-90 \mathrm{~g}$ & 14.16 & $\mathrm{Kr}-95 \mathrm{~g}$ & 0.02 & $\mathrm{Nb}-104 \mathrm{~g}$ & 0.02 & $\mathrm{Cs}-141 \mathrm{~g}$ & 0.40 \\
\hline $\mathrm{Se}-$ & $89 \mathrm{~g}$ & 1.68 & $\mathrm{Se}-91 \mathrm{~g}$ & 0.02 & $\mathrm{Rb}-95 \mathrm{~g}$ & 0.06 & $\mathrm{Nb}-105 \mathrm{~g}$ & 0.36 & $\mathrm{La}-146 \mathrm{~g}$ & 0.01 \\
\hline $\mathrm{Br}-$ & 899 & 3.67 & $\mathrm{Br}-9 \mathrm{lg}$ & 3.33 & $\mathrm{Y}-97 \mathrm{~g}$ & 0.16 & In $-127 \mathrm{~g}$ & 0.05 & $\mathrm{La}-147 \mathrm{~g}$ & 0.01 \\
\hline Se- & $90 \mathrm{~g}$ & 0.35 & $\mathrm{Br}-92 \mathrm{~g}$ & 0.82 & $Y-97 m$ & 0.07 & $\mathrm{sb}-134 \mathrm{~g}$ & 0.04 & & \\
\hline $\mathrm{Br}-$ & $90 \mathrm{~g}$ & 7.76 & $\mathrm{Kr}-92 \mathrm{~g}$ & 0.02 & $S r-98 g$ & 0.01 & $s b-135 g$ & 0.78 & & \\
\hline $\mathrm{Se}-$ & $91 \mathrm{~g}$ & 0.10 & $\mathrm{Rb}-92 \mathrm{~g}$ & 0.01 & $Y-98 g$ & 0.23 & $\mathrm{Te}-136 \mathrm{~g}$ & 1.27 & & \\
\hline $\mathrm{Br}-$ & $91 \mathrm{~g}$ & 4.00 & $\mathrm{Kr}-93 \mathrm{~g}$ & 0.31 & $Y-98 m$ & 1.06 & $\mathrm{Te}-137 \mathrm{~g}$ & 0.94 & & \\
\hline $\mathrm{Br}-$ & $92 \mathrm{~g}$ & 2.13 & $R b-93 g$ & 1.58 & $Y-99 \mathrm{~g}$ & 2.12 & $\mathrm{I}-137 \mathrm{~g}$ & 14.88 & & \\
\hline $\mathrm{Kr}-$ & $92 \mathrm{~g}$ & 0.01 & $\mathrm{Kr}-94 \mathrm{~g}$ & 0.34 & $\mathrm{Y}-100 \mathrm{~g}$ & 0.12 & $\mathrm{Te}-138 \mathrm{~g}$ & 0.10 & & \\
\hline $\mathrm{Br}-$ & $93 g$ & 0.16 & $\mathrm{Rb}-94 \mathrm{~g}$ & 11.24 & $Y-101 g$ & 0.03 & $I-138 \mathrm{~g}$ & 9.97 & & \\
\hline $\mathrm{Kr}-$ & $93 \mathrm{~g}$ & 0.20 & $\mathrm{Kr}-95 \mathrm{~g}$ & 0.17 & $Y-102 g$ & 0.07 & $\mathrm{I}-139 \mathrm{~g}$ & 2.89 & & \\
\hline $\mathrm{Rb}$-. & $93 \mathrm{~g}$ & 0.66 & $R b-95 g$ & 6.71 & $\mathrm{Nb}-103 \mathrm{~g}$ & 0.02 & $\mathrm{Cs}-141 \mathrm{~g}$ & 0.13 & & \\
\hline $\mathrm{Br}-$ & $94 \mathrm{~g}$ & 0.08 & $\mathrm{Kr}-96 \mathrm{~g}$ & 0.01 & $2 \mathrm{r}-104 \mathrm{~g}$ & 0.02 & $\mathrm{Cs}-142 \mathrm{~g}$ & 0.07 & & \\
\hline Kr- & $94 \mathrm{~g}$ & 3.51 & $\mathrm{Rb}-96 \mathrm{~g}$ & 1.15 & $\mathrm{Nb}-104 \mathrm{~g}$ & 0.02 & $\mathrm{Cs}-143 \mathrm{~g}$ & 0.58 & & \\
\hline $\mathrm{Rb}-$ & $94 \mathrm{~g}$ & 5.09 & $\mathrm{Rb}-97 \mathrm{~g}$ & 0.26 & $\mathrm{Nb}-105 \mathrm{~g}$ & 0.47 & $\mathrm{Cs}-144 \mathrm{~g}$ & 0.04 & & \\
\hline $\mathrm{Kr}-$ & $95 \mathrm{~g}$ & 0.16 & $Y-97 \mathrm{~g}$ & 0.07 & In $-127 \mathrm{~g}$ & 0.05 & $\mathrm{La}-147 \mathrm{~g}$ & 0.04 & & \\
\hline$R b-$ & $95 \mathrm{~g}$ & 15.31 & $Y-97 m$ & 0.18 & $5 n-133 g$ & 0.02 & $\mathrm{La}-149 \mathrm{~g}$ & 0.04 & & \\
\hline $\mathrm{Kr}-$ & $96 \mathrm{~g}$ & 0.04 & $S r-98 g$ & 0.25 & $\mathrm{sn}-134 \mathrm{~g}$ & 0.08 & & & & \\
\hline$R b-$ & 969 & 12.68 & $Y-98 \mathrm{~g}$ & 0.23 & $\mathrm{Sb}-134 \mathrm{~g}$ & 0.02 & & & & \\
\hline$R D-$ & $97 \mathrm{~g}$ & 5.81 & $Y-98 m$ & 7.79 & $\mathrm{sb}-135 \mathrm{~g}$ & 1.94 & & & & \\
\hline Sr- & $97 \mathrm{~g}$ & 0.02 & $S r-99 g$ & 0.02 & $\mathrm{sb}-136 \mathrm{~g}$ & 0.09 & & & & \\
\hline$Y-$ & $97 \mathrm{~g}$ & 0.02 & $Y-99 g$ & 3.58 & $\mathrm{Te}-136 \mathrm{~g}$ & 0.57 & & & & \\
\hline$Y-$ & $97 \mathrm{~m}$ & 0.11 & $5 r-100 g$ & 0.02 & $\mathrm{Te}-137 \mathrm{~g}$ & 0.94 & & & & \\
\hline $\mathrm{Bb}-$ & $98 \mathrm{~g}$ & 0.52 & $\mathrm{Y}-100 \mathrm{~g}$ & 0.87 & $\mathrm{I}-137 \mathrm{~g}$ & 6.15 & & & & \\
\hline $5 r-$ & $98 \mathrm{~g}$ & 0.27 & $Y-101 \mathrm{~g}$ & 0.66 & $\mathrm{Te}-138 \mathrm{~g}$ & 0.34 & & & & \\
\hline$Y-$ & $98 \mathrm{~g}$ & 0.12 & $\mathrm{Y}-102 \mathrm{~g}$ & 0.35 & $I-138 \mathrm{~g}$ & 6.25 & & & & \\
\hline & $98 \mathrm{~m}$ & 5.61 & $Y-103 g$ & 0.05 & $\mathrm{I}-139 \mathrm{~g}$ & 4.62 & & & & \\
\hline b- & $99 \mathrm{~g}$ & 0.01 & $\mathrm{Zr}-103 \mathrm{~g}$ & 0.01 & $\mathrm{I}-140 \mathrm{~g}$ & 0.20 & & & & \\
\hline
\end{tabular}


Table B-II (Cont.)

$$
(0.0 \mathrm{~s})
$$

$(1.0 \mathrm{~s})$

\begin{tabular}{|c|c|c|c|c|c|}
\hline Nuclide & 8 & Nuclide & 8 & Nuclide & 8 \\
\hline$S r-99 g$ & 0.03 & $\mathrm{Nb}-103 \mathrm{~g}$ & 0.02 & $\mathrm{Xe}-141 \mathrm{~g}$ & 0.02 \\
\hline$Y-99 \mathrm{~g}$ & 2.10 & $\mathrm{Zr}-104 \mathrm{~g}$ & 0.01 & $\mathrm{Cs}-14 \mathrm{Ig}$ & 0.05 \\
\hline$S r-100 g$ & 0.03 & $2 r-105 g$ & 0.01 & $\mathrm{Xe}-142 \mathrm{~g}$ & 0.06 \\
\hline$y-100 \mathrm{~g}$ & 0.76 & $\mathrm{Nb}-105 \mathrm{~g}$ & 0.31 & $\mathrm{Cs}-142 \mathrm{~g}$ & 0.18 \\
\hline$S r-101 g$ & 0.03 & $\mathrm{Nb}-106 \mathrm{~g}$ & 0.03 & $x e-143 g$ & 0.02 \\
\hline$Y-101 \mathrm{~g}$ & 0.78 & $\mathrm{Nb}-107 \mathrm{~g}$ & 0.04 & $\mathrm{Cs}-143 \mathrm{~g}$ & 1.50 \\
\hline$Y-102 g$ & 0.29 & $\mathrm{In}-127 \mathrm{~g}$ & 0.02 & $\mathrm{Xe}-144 \mathrm{~g}$ & 0.01 \\
\hline$Y-103 g$ & 0.28 & $\mathrm{In}-130 \mathrm{~g}$ & 0.09 & $\mathrm{Cs}-144 \mathrm{~g}$ & 0.42 \\
\hline $\mathrm{Nb}-103 \mathrm{~g}$ & 0.01 & $\mathrm{In}-130 \mathrm{~m}$ & 0.06 & $C s-145 \mathrm{~g}$ & 0.06 \\
\hline $\mathrm{Y}-104 \mathrm{~g}$ & 0.02 & $I n-131 g$ & 0.04 & $\mathrm{La}-147 \mathrm{~g}$ & 0.03 \\
\hline $2 r-105 g$ & 0.02 & $s n-133 g$ & 0.03 & $\mathrm{La}-148 \mathrm{~g}$ & 0.02 \\
\hline $\mathrm{Nb}-105 \mathrm{~g}$ & 0.15 & $S n-134 g$ & 0.30 & $\mathrm{La}-149 \mathrm{~g}$ & 0.06 \\
\hline $\mathrm{Nb}-106 \mathrm{~g}$ & 0.03 & $\mathrm{Sb}-135 \mathrm{~g}$ & 2.19 & & \\
\hline $\mathrm{Nb}-107 \mathrm{~g}$ & 0.04 & $\mathrm{sb}-136 \mathrm{~g}$ & 0.67 & & \\
\hline $\mathrm{Ag}-124 \mathrm{~g}$ & 0.01 & $\mathrm{Te}-136 \mathrm{~g}$ & 0.16 & & \\
\hline $\mathrm{In}-130 \mathrm{~g}$ & 0.05 & $s b-137 g$ & 0.04 & & \\
\hline $\mathrm{In}-130 \mathrm{~m}$ & 0.08 & $\mathrm{Te}-137 \mathrm{~g}$ & 0.51 & & \\
\hline $\mathrm{In}-131 \mathrm{~g}$ & 0.07 & $I-137 g$ & 1.60 & & \\
\hline$I n-131 \mathrm{~m}$ & 0.16 & $\mathrm{Te}-138 \mathrm{~g}$ & 0.47 & & \\
\hline $\mathrm{In}-132 \mathrm{~g}$ & 0.14 & $\mathrm{I}-138 \mathrm{~g}$ & 2.29 & & \\
\hline$I n-133 g$ & 0.07 & $\mathrm{Te}-139 \mathrm{~g}$ & 0.08 & & \\
\hline$S n-133 g$ & 0.02 & $\mathrm{I}-139 \mathrm{~g}$ & 3.63 & & \\
\hline$S n-134 g$ & 0.22 & $\mathrm{Te}-140 \mathrm{~g}$ & 0.01 & & \\
\hline $5 n-135 g$ & 0.01 & $\mathrm{I}-140 \mathrm{~g}$ & 1.22 & & \\
\hline $\mathrm{Sb}-135 \mathrm{~g}$ & 1.22 & $\mathrm{I}-141 \mathrm{~g}$ & 0.33 & & \\
\hline $\mathrm{Sb}-136 \mathrm{~g}$ & 0.59 & $\mathrm{Xe}-141 \mathrm{~g}$ & 0.02 & & \\
\hline $\mathrm{Te}-136 \mathrm{~g}$ & 0.06 & $\mathrm{Cs}-141 \mathrm{~g}$ & 0.01 & & \\
\hline$S b-137 g$ & 0.06 & $\mathrm{Xe}-142 \mathrm{~g}$ & 0.15 & & \\
\hline $\mathrm{Te}-137 \mathrm{~g}$ & 0.24 & $\mathrm{Cs}-142 \mathrm{~g}$ & 0.19 & & \\
\hline $\mathrm{I}-137 \mathrm{~g}$ & 0.61 & $\mathrm{Xe}-143 \mathrm{~g}$ & 0.09 & & \\
\hline$S b-138 g$ & 0.01 & $\mathrm{Cs}-143 \mathrm{~g}$ & 1.71 & & \\
\hline $\mathrm{Te}-138 \mathrm{~g}$ & 0.28 & $\mathrm{Xe}-144 \mathrm{~g}$ & 0.04 & & \\
\hline$I-138 \mathrm{~g}$ & 0.95 & $\mathrm{Cs}-144 \mathrm{~g}$ & 1.55 & & \\
\hline $\mathrm{Te}-139 \mathrm{~g}$ & 0.10 & $\mathrm{Cs}-145 \mathrm{~g}$ & 1.45 & & \\
\hline$I-139 g$ & 1.83 & $\mathrm{Cs}-146 \mathrm{~g}$ & 0.11 & & \\
\hline $\mathrm{I}-140 \mathrm{~g}$ & 1.04 & $\mathrm{Cs}-147 \mathrm{~g}$ & 0.05 & & \\
\hline $\mathrm{I}-141 \mathrm{~g}$ & 0.56 & $\mathrm{La}-147 \mathrm{~g}$ & 0.01 & & \\
\hline $\mathrm{Xe}-14 \mathrm{lg}$ & 0.01 & $\mathrm{La}-148 \mathrm{~g}$ & 0.04 & & \\
\hline $\mathrm{I}-142 \mathrm{~g}$ & 0.11 & $\mathrm{La}-149 \mathrm{~g}$ & 0.05 & & \\
\hline $\mathrm{Xe}-142 \mathrm{~g}$ & 0.10 & & & & \\
\hline $\mathrm{Cs}-142 \mathrm{~g}$ & 0.10 & & & & \\
\hline$X e-143 g$ & 0.07 & & & & \\
\hline $\mathrm{Cs}-143 \mathrm{~g}$ & 0.93 & & & & \\
\hline $\mathrm{Xe}-144 \mathrm{~g}$ & 0.03 & & & & \\
\hline$C s-144 \mathrm{~g}$ & 1.17 & & & & \\
\hline$c s-145 g$ & 1.79 & & & & \\
\hline$C s-146 \mathrm{~g}$ & 0.32 & & & & \\
\hline$c s-147 \mathrm{~g}$ & 0.07 & & & & \\
\hline $\mathrm{La}-148 \mathrm{~g}$ & 0.03 & & & & \\
\hline$L a-149 g$ & 0.02 & & & & \\
\hline
\end{tabular}

\author{
$(10.0 s)$
}

$(30.05)$

Nuclide \& Nuclide 8 
TABLE B-III

235U FISSION PULSE

\section{PER CENT CONTRIBUTION PER PRECURSOR GREATER THAN $0.01 \%$} FOR ENERGIES ABOVE $4.0 \mathrm{MeV}$

$$
(0.05)
$$

\begin{tabular}{ll} 
Nuclide & \multicolumn{1}{l}{} \\
$\mathrm{Ga}-83 \mathrm{~g}$ & 0.03 \\
$\mathrm{Ge}-85 \mathrm{~g}$ & 0.02 \\
$\mathrm{As}-86 \mathrm{~g}$ & 0.04 \\
$\mathrm{As}-87 \mathrm{~g}$ & 0.38 \\
$\mathrm{As}-88 \mathrm{~g}$ & 0.05 \\
$\mathrm{As}-89 \mathrm{~g}$ & 0.01 \\
$\mathrm{Se}-89 \mathrm{~g}$ & 0.03 \\
$\mathrm{Br}-90 \mathrm{~g}$ & 0.01 \\
$\mathrm{Br}-91 \mathrm{~g}$ & 7.99 \\
$\mathrm{Br}-92 \mathrm{~g}$ & 81.03 \\
$\mathrm{Br}-93 \mathrm{~g}$ & 0.02 \\
$\mathrm{Br}-94 \mathrm{~g}$ & 0.01 \\
$\mathrm{Rb}-95 \mathrm{~g}$ & 2.16 \\
$\mathrm{Rb}-96 \mathrm{~g}$ & 3.91 \\
$\mathrm{Rb}-97 \mathrm{~g}$ & 2.61 \\
$\mathrm{Rb}-98 \mathrm{~g}$ & 1.43 \\
$\mathrm{I}-140 \mathrm{~g}$ & 0.01 \\
$\mathrm{I}-141 \mathrm{~g}$ & 0.19
\end{tabular}

$$
\text { (1.0s) }
$$

$$
(5.05)
$$

$\begin{array}{ll}\text { Nuclide } & \\ \text { Ga- } 83 \mathrm{~g} & 0.02 \\ \mathrm{As}-85 \mathrm{~g} & 0.04 \\ \mathrm{As}-86 \mathrm{~g} & 0.13 \\ \mathrm{As}-87 \mathrm{~g} & 0.25 \\ \mathrm{Se}-89 \mathrm{~g} & 0.03 \\ \mathrm{Br}-90 \mathrm{~g} & 0.06 \\ \mathrm{Br}-91 \mathrm{~g} & 16.83 \\ \mathrm{Br}-92 \mathrm{~g} & 78.66 \\ \mathrm{Rb}-95 \mathrm{~g} & 2.40 \\ \mathrm{Rb}-96 \mathrm{~g} & 0.90 \\ \mathrm{Rb}-97 \mathrm{~g} & 0.30 \\ \mathrm{Rb}-98 \mathrm{~g} & 0.02 \\ \mathrm{I}-140 \mathrm{~g} & 0.04 \\ \mathrm{I}-141 \mathrm{~g} & 0.28 \\ & \end{array}$

\begin{tabular}{|c|c|c|c|c|c|}
\hline Nuclide & 8 & Nuclide & 8 & Nuclide & 담 \\
\hline$G a-82 g$ & 0.03 & $A s-85 g$ & 39.14 & $A s-85 g$ & 67.92 \\
\hline$A s-85 g$ & 3.94 & $A s-86 \mathrm{~g}$ & 2.93 & $\mathrm{Br}-90 \mathrm{~g}$ & 32.08 \\
\hline$A s-86 \mathrm{~g}$ & 2.52 & $\mathrm{Br}-90 \mathrm{~g}$ & 44.25 & & \\
\hline As- $87 \mathrm{~g}$ & 0.01 & $\mathrm{BI}-91 \mathrm{~g}$ & 11.82 & & \\
\hline $\mathrm{Se}-89 \mathrm{~g}$ & 0.02 & $B I-92 g$ & 0.05 & & \\
\hline $\mathrm{Br}-90 \mathrm{~g}$ & 5.55 & $\mathrm{Kr}-95 \mathrm{~g}$ & 0.02 & & \\
\hline $\mathrm{Br}-91 \mathrm{~g}$ & 69.67 & $R b-95 g$ & 1.06 & & \\
\hline $\mathrm{Br}-92 \mathrm{~g}$ & 14.93 & $\mathrm{I}-140 \mathrm{~g}$ & 0.71 & & \\
\hline $\mathrm{Kr}-95 \mathrm{~g}$ & 0.03 & & & & \\
\hline $\mathrm{Rb}-95 \mathrm{~g}$ & 2.29 & & & & \\
\hline $\mathrm{I}-140 \mathrm{~g}$ & 0.71 & & & & \\
\hline $\mathrm{I}-141 \mathrm{~g}$ & 0.29 & & & & \\
\hline $\mathrm{Cs}-147 \mathrm{~g}$ & 0.02 & & & & \\
\hline
\end{tabular}

$$
(10.05)
$$

$(30.0 s)$

\section{TABLE B-IV \\ 238U FISSION PULSE}

PER CENT CONTRIBUTION PER PRECURSOR GREATER THAN $0.01 \%$ FOR ENERGIES ABOVE $0.0 \mathrm{MeV}$
$(0.05)$
(1.0s)

\begin{tabular}{|c|c|c|c|c|c|c|c|c|c|c|c|}
\hline Nuc & Lide & $q$ & Nuclide & 8 & Nuclide & 8 & Nuc & ide & $\frac{8}{8}$ & Nuclide & $\frac{\circ}{8}$ \\
\hline a- & $81 \mathrm{~g}$ & 0.05 & $\mathrm{Ga}-81 \mathrm{~g}$ & 0.10 & $\mathrm{Ga}-81 \mathrm{~g}$ & 0.06 & $\mathrm{Ga}-$ & $81 \mathrm{~g}$ & 0.01 & $A s-85 g$ & 0.04 \\
\hline $\mathrm{Ga-}$ & 829 & 0.11 & $\mathrm{Ga}-82 \mathrm{~g}$ & . & $\mathrm{Ge}-84 \mathrm{~g}$ & 0.14 & $\mathrm{Ge}-$ & $84 \mathrm{~g}$ & 0.02 & $\mathrm{Se}-87 \mathrm{~g}$ & 0.07 \\
\hline $\mathrm{Ga}-$ & $83 g$ & 0.22 & $G a-83 y$ & 0.08 & As $-85 \mathrm{~g}$ & 9.96 & As - & $85 \mathrm{~g}$ & 5.72 & $\mathrm{Br}-87 \mathrm{~g}$ & 4.39 \\
\hline $\mathrm{Ga}-$ & $84 \mathrm{~g}$ & 0.09 & $\mathrm{Ge}-84 \mathrm{~g}$ & 0.26 & $A s-86 \mathrm{~g}$ & 0.18 & As- & $86 \mathrm{~g}$ & 0.01 & $\mathrm{Br}-88 \mathrm{~g}$ & 13.96 \\
\hline $\mathrm{Ge}-$ & $84 \mathrm{~g}$ & 0.14 & $\mathrm{Ge}-85 \mathrm{~g}$ & 0.10 & $\mathrm{Se}-87 \mathrm{~g}$ & 0.07 & $\mathrm{Se}-$ & $87 \mathrm{~g}$ & 0.12 & $\mathrm{Br}-89 \mathrm{~g}$ & 4.72 \\
\hline As- & $84 \mathrm{~g}$ & 0.01 & $A s-85 g$ & 7.00 & $\mathrm{Br}-87 \mathrm{~g}$ & 0.19 & $\mathrm{Br}-$ & $87 \mathrm{~g}$ & 0.70 & $\mathrm{Br}-90 \mathrm{~g}$ & 0.01 \\
\hline $\mathrm{Ga}-$ & $85 \mathrm{~g}$ & 0.01 & $\mathrm{Ge}-86 \mathrm{~g}$ & 0.02 & $\mathrm{Se}-88 \mathrm{~g}$ & 0.17 & $\mathrm{Se}-$ & $88 \mathrm{~g}$ & 0.05 & $R b-92 g$ & 0.01 \\
\hline $\mathrm{Ge}-$ & $85 \mathrm{~g}$ & 0.48 & As- $86 \mathrm{~g}$ & 0.72 & $\mathrm{Br}-88 \mathrm{~g}$ & 1.90 & $B r-$ & $88 \mathrm{~g}$ & 5.09 & $R b-93 g$ & 2.59 \\
\hline As- & $85 \mathrm{~g}$ & 2.83 & As- $87 \mathrm{~g}$ & 0.61 & $\mathrm{BI}-89 \mathrm{~g}$ & 12.02 & $\mathrm{Br}-$ & 899 & 17.25 & $\mathrm{Rb}-94 \mathrm{~g}$ & 0.54 \\
\hline $\mathrm{je}-$ & $86 g$ & 0.11 & $\mathrm{Se}-87 \mathrm{~g}$ & 0.02 & $\mathrm{Br}-90 \mathrm{~g}$ & 10.27 & $\mathrm{Br}-$ & $90 \mathrm{~g}$ & 4.74 & $Y-97 \mathrm{~g}$ & 0.02 \\
\hline As- & $86 \mathrm{~g}$ & 0.47 & $\mathrm{Br}-87 \mathrm{~g}$ & 0.02 & $B I-91 g$ & 0.26 & $K r-$ & $92 \mathrm{~g}$ & 0.02 & $\mathrm{Nb}-104 \mathrm{~g}$ & 0.04 \\
\hline
\end{tabular}
(5.0s)
(10.0s)
$(30.0 s)$ 
Table B-IV (Cont.)

$$
(0.0 s)
$$

(1.0s)

\begin{tabular}{|c|c|c|c|}
\hline Nuclide & 8 & Nuclide & 8 \\
\hline$G e-87 g$ & 0.01 & $\mathrm{Se}-88 \mathrm{~g}$ & 0.19 \\
\hline As $-87 \mathrm{~g}$ & 1.89 & $\mathrm{Br}-88 \mathrm{~g}$ & 0.30 \\
\hline As $-88 \mathrm{~g}$ & 0.50 & $\mathrm{Se}-89 \mathrm{~g}$ & 0.90 \\
\hline Se- $88 \mathrm{~g}$ & 0.09 & $\mathrm{Br}-89 \mathrm{~g}$ & 3.92 \\
\hline $\mathrm{Br}-88 \mathrm{~g}$ & 0.08 & $\mathrm{Se}-90 \mathrm{~g}$ & 0.33 \\
\hline As- $89 \mathrm{~g}$ & 0.21 & $\mathrm{Br}-90 \mathrm{~g}$ & 8.41 \\
\hline $\mathrm{Se}-89 \mathrm{~g}$ & 1.49 & $\mathrm{Se}-91 \mathrm{~g}$ & 0.08 \\
\hline Br- $89 \mathrm{~g}$ & 1.21 & $\mathrm{Br}-91 \mathrm{~g}$ & 4.75 \\
\hline $\mathrm{Se}-90 \mathrm{~g}$ & 0.53 & $\mathrm{Br}-92 \mathrm{~g}$ & 2.31 \\
\hline $\mathrm{Br}-90 \mathrm{~g}$ & 3.56 & $\mathrm{Kr}-92 \mathrm{~g}$ & 0.03 \\
\hline $\mathrm{Se}-91 \mathrm{~g}$ & 0.33 & $\mathrm{Br}-93 \mathrm{~g}$ & 0.08 \\
\hline Br- $91 \mathrm{~g}$ & $4.5 ?$ & $\mathrm{Kr}-93 \mathrm{~g}$ & 0.93 \\
\hline $\mathrm{Se}-92 \mathrm{~g}$ & 0.03 & $R b-93 g$ & 0.53 \\
\hline $\mathrm{Br}-92 \mathrm{~g}$ & 4.84 & $\mathrm{KI}-94 \mathrm{~g}$ & 0.53 \\
\hline$K r-92 g$ & 0.01 & $\mathrm{Rb}-94 \mathrm{~g}$ & 6.84 \\
\hline $\mathrm{Br}-93 \mathrm{~g}$ & 1.29 & $\mathrm{Kr}-95 \mathrm{~g}$ & 0.38 \\
\hline $\mathrm{Kr}-93 \mathrm{~g}$ & 0.49 & $\mathrm{Rb}-95 \mathrm{~g}$ & 5.60 \\
\hline $\mathrm{Rb}-93 \mathrm{~g}$ & 0.15 & $\mathrm{Kr}-96 \mathrm{~g}$ & 0.05 \\
\hline $\mathrm{Br}-94 \mathrm{~g}$ & 0.29 & $\mathrm{Rb}-96 \mathrm{~g}$ & 1.63 \\
\hline $\mathrm{Kr}-94 \mathrm{~g}$ & 4.37 & $\mathrm{Rb}-97 \mathrm{~g}$ & 0.22 \\
\hline$R b-94 g$ & 2.20 & $Y-97 g$ & 0.03 \\
\hline $\mathrm{Kr}-95 \mathrm{~g}$ & 0.29 & $Y-97 m$ & 0.07 \\
\hline$R b-95 g$ & 9.79 & Sr- $98 \mathrm{~g}$ & 0.29 \\
\hline$K r-96 \mathrm{~g}$ & 0.16 & $Y-98 \mathrm{~g}$ & 0.09 \\
\hline $\mathrm{Rb}-96 \mathrm{~g}$ & 13.46 & $Y-98 m$ & 5.25 \\
\hline $\mathrm{Kr}-97 \mathrm{~g}$ & 0.02 & $S r-99 g$ & 0.04 \\
\hline $\mathrm{Rb}-97 \mathrm{~g}$ & 3.92 & $Y-99 \mathrm{~g}$ & 2.77 \\
\hline$Y-97 m$ & 0.03 & $S r-100 \mathrm{~g}$ & 0.08 \\
\hline$R b-98 g$ & 1.44 & $\mathrm{Y}-100 \mathrm{~g}$ & 0.88 \\
\hline$S r-98 g$ & 0.26 & $S r-101 g$ & 0.01 \\
\hline$Y-98 \mathrm{~g}$ & 0.04 & $\mathrm{Y}-101 \mathrm{~g}$ & 1.10 \\
\hline$Y-98 m$ & 1.81 & $Y-102 g$ & 0.95 \\
\hline $\mathrm{Rb}-99 \mathrm{~g}$ & 0.33 & $\mathrm{Y}-103 \mathrm{~g}$ & 0.30 \\
\hline$s r-99 g$ & 0.04 & $2 r-103 g$ & 0.02 \\
\hline$Y-99 \mathrm{~g}$ & 1.20 & $\mathrm{Nb}-103 \mathrm{~g}$ & 0.02 \\
\hline$S r-100 g$ & 0.07 & $2 r-104 g$ & 0.05 \\
\hline$Y-100 g$ & 0.59 & $2 r-105 g$ & 0.09 \\
\hline$S r-101 g$ & 0.12 & $\mathrm{Nb}-105 \mathrm{~g}$ & 1.01 \\
\hline $\mathrm{Y}-101 \mathrm{~g}$ & 1.03 & $\mathrm{zr}-106 \mathrm{~g}$ & 0.02 \\
\hline$S r-102 g$ & 0.02 & $\mathrm{Nb}-106 \mathrm{~g}$ & 0.19 \\
\hline$Y-102 \mathrm{~g}$ & 0.63 & $\mathrm{Nb}-107 \mathrm{~g}$ & 0.35 \\
\hline $\mathrm{Y}-103 \mathrm{~g}$ & 1.33 & $\mathrm{Tc}-110 \mathrm{~g}$ & 0.01 \\
\hline $2 r-103 g$ & 0.01 & $\mathrm{Tc}-111 \mathrm{~g}$ & 0.02 \\
\hline$Y-: 04 \mathrm{~g}$ & 0.24 & $\mathrm{Rh}-117 \mathrm{~g}$ & 0.02 \\
\hline $2 r-104 \mathrm{~g}$ & 0.02 & $\mathrm{In}-129 \mathrm{~g}$ & 0.16 \\
\hline$y-105 g$ & 0.11 & $\mathrm{In}-129 \mathrm{~m}$ & 0.02 \\
\hline $2 r-105 g$ & 0.12 & In $-130 \mathrm{~g}$ & 0.20 \\
\hline $\mathrm{Nb}-105 \mathrm{~g}$ & 0.37 & In-130m & 0.14 \\
\hline
\end{tabular}

$$
\text { (5.0s) }
$$$$
(10.05)
$$

Nuclide

$\mathrm{Kr}-92 \mathrm{~g} \quad 0.03$

Rb- $92 \mathrm{~g} \quad 0.02$

$\mathrm{Kr}-93 \mathrm{~g} \quad 0.60$

$\mathrm{Rb}-93 \mathrm{~g} \quad 2.32$

$\mathrm{Rb}-94 \mathrm{~g} 14.01$

Kr- $95 \mathrm{~g} \quad 0.06$

$\mathrm{Rb}-95 \mathrm{~g} \quad 0.15$

$Y-97 \mathrm{~g} \quad 0.10$

$Y-97 \mathrm{~m} \quad 0.03$

Sr- $98 \mathrm{~g} \quad 0.02$

$Y-98 \mathrm{~g} \quad 0.13$

$Y-98 \mathrm{~m} \quad 1.42$

$Y-99 \mathrm{~g} \quad 2.43$

$Y-100 \mathrm{~g}$

$Y-101 \mathrm{~g} \quad 0.06$

$Y-102 \mathrm{~g} \quad 0.24$

$\begin{array}{ll}2 r-103 g & 0.02\end{array}$

$\mathrm{Nb}-103 \mathrm{~g} \quad 0.04$

$2 r-104 \mathrm{~g} \quad 0.09$

$\mathrm{Nb}-104 \mathrm{~g} \quad 0.04$

$\mathrm{Nb}-105 \mathrm{~g} \quad 2.15$

$\mathrm{Nb}-106 \mathrm{~g} \quad 0.08$

$\mathrm{Nb}-107 \mathrm{~g} \quad 0.05$

Tc-111g 0.03

In $-127 \mathrm{~g}$

In $-129 \mathrm{~g}$

In $-129 \mathrm{~m}$

In $-130 \mathrm{~g}$

$\mathrm{Sn}-133 \mathrm{~g}$

$\mathrm{Sn}-134 \mathrm{~g}$

$\mathrm{Sb}-134 \mathrm{~g}$

$\mathrm{sb}-135 \mathrm{~g}$

$\mathrm{Sb}-136 \mathrm{~g}$

$\mathrm{Te}-136 \mathrm{~g}$

$\mathrm{Te}-137 \mathrm{~g}$

$\mathrm{I}-137 \mathrm{~g}$

$\mathrm{Te}-138 \mathrm{~g}$

$\mathrm{I}-138 \mathrm{~g}$

$\mathrm{Te}-139 \mathrm{~g}$

$\mathrm{I}-139 \mathrm{~g}$

$\mathrm{Te}-140 \mathrm{~g}$

$\mathrm{I}-140 \mathrm{~g}$

$\mathrm{I}-141 \mathrm{~g}$

$\mathrm{Xe}-14 \mathrm{Ig}$

$\mathrm{Cs}-141 \mathrm{~g}$

$\mathrm{Xe}-142 \mathrm{~g}$

$\mathrm{Cs}-142 \mathrm{~g}$

$\mathrm{Xe}-143 \mathrm{~g}$
0.18

Nuclide$$
\mathrm{Rb}
$$$$
\mathrm{Rb}-92 \mathrm{~g} \quad 0.03
$$

$\mathrm{Kr}-93 \mathrm{~g} \quad 0.13$

$\mathrm{Rb}-93 \mathrm{~g} \quad 4.24$

$\mathrm{Rb}-94 \mathrm{~g} \quad 12.64$

Y- $97 \mathrm{~g} \quad 0.13$

$Y-98 \mathrm{~g} \quad 0.07$

$Y-98 \mathrm{~m} \quad 0.04$

$\mathrm{Y}-99 \mathrm{~g}$

0.65

$Y-102 \mathrm{~g}$

0.02

$\mathrm{Nb}-103 \mathrm{~g} \quad 0.02$

$\begin{array}{ll}\mathrm{Zr}-104 \mathrm{~g} & 0.08\end{array}$

$\mathrm{Nb}-104 \mathrm{~g} \quad 0.08$

$\mathrm{Nb}-105 \mathrm{~g} \quad 1.98$

$\mathrm{Tc}-111 \mathrm{~g} \quad 0.02$
$\mathrm{Rh}$

$\mathrm{Rh}-115 \mathrm{~g} \quad 0.02$

In-127g 0.02

In-129m 0.03

$\mathrm{sn}-133 \mathrm{~g} \quad 0.03$

$\mathrm{Sn}-134 \mathrm{~g} \quad 0.10$

$\mathrm{Sb}-134 \mathrm{~g} \quad 0.12$

Sb-135g 3.79

$\mathrm{Sb}-136 \mathrm{~g} \quad 0.03$

$\mathrm{Te}-136 \mathrm{~g} \quad 2.51$

$\mathrm{Te}-137 \mathrm{~g} \quad 2.52$

$I-137 \mathrm{~g} \quad 13.44$

0.02

$\begin{array}{ll}\mathrm{Te}-138 \mathrm{~g} & 0.58\end{array}$

I- $138 \mathrm{~g} \quad 14.48$

0.04

0.03

0.08

0.85

0.05

B. 04

0.67

0.95

2.14

4.37

1.60

7.48

0.02

9.28

0.04

0.76

0.03

0.03

0.04

0.12

0.17

$I-139 \mathrm{~g} \quad 6.86$

$\mathrm{I}-140 \mathrm{~g} \quad 0.05$

$\mathrm{Xe}-141 \mathrm{~g} \quad 0.01$

Cs-14lg 0.11

$\mathrm{Xe}-142 \mathrm{~g} \quad 0.02$

Cs-142g 0.09

Cs $-143 \mathrm{~g} \quad 0.86$

$\mathrm{Xe}-144 \mathrm{~g} \quad 0.01$

$\mathrm{Cs}-144 \mathrm{~g} \quad 0.10$

$\mathrm{La}-147 \mathrm{~g} \quad 0.06$

$\mathrm{La}-148 \mathrm{~g} \quad 0.02$
$\mathrm{La}-149 \mathrm{~g}$

$\mathrm{La}-149 \mathrm{~g} \quad 0.19$
$(30.05)$

Nuclide of

$\mathrm{Nb}-105 \mathrm{~g} \quad 0.09$

$\mathrm{Rh}-115 \mathrm{~g} \quad 0.02$

$\mathrm{Sb}-134 \mathrm{~g} \quad 0.20$

$\mathrm{Sb}-135 \mathrm{~g} \quad 0.01$

$\mathrm{Te}-136 \mathrm{~g} \quad 7.84$

$\mathrm{Te}-137 \mathrm{~g} \quad 0.31$

$I-137 \mathrm{~g} \quad 53.29$

$I-138 \mathrm{~g} \quad 11.24$

$\mathrm{I}-139 \mathrm{~g} \quad 0.13$

Cs-141g 0.40

$\mathrm{La}-146 \mathrm{~g} \quad 0.02$

La-147g 0.02

\section{Continued}


Table B-IV (Cont.)

$$
(0.0 s) \quad(1.0 s)
$$

\begin{tabular}{|c|c|c|c|}
\hline Nuclide & 8 & Nuclide & 8 \\
\hline $2 r-106 g$ & 0.01 & In-131g & 0.17 \\
\hline $\mathrm{Nb}-106 \mathrm{~g}$ & 0.12 & In $-132 \mathrm{~g}$ & 0.01 \\
\hline $\mathrm{Nb}-107 \mathrm{~g}$ & 0.26 & $S n-133 g$ & 0.10 \\
\hline $\mathrm{Nb}-108 \mathrm{~g}$ & 0.03 & $\mathrm{Sn}-134 \mathrm{~g}$ & 2.21 \\
\hline $\mathrm{Tc}-112 \mathrm{~g}$ & 0.01 & $\mathrm{Sb}-134 \mathrm{~g}$ & 0.01 \\
\hline $\mathrm{Ag}-124 \mathrm{~g}$ & 0.02 & $S n-135 g$ & 0.11 \\
\hline $\mathrm{Ag}-125 \mathrm{~g}$ & 0.02 & $S b-135 g$ & 6.60 \\
\hline $\mathrm{Ag}-126 \mathrm{~g}$ & 0.01 & $S n-136 g$ & 0.02 \\
\hline $\mathrm{Ag}-127 \mathrm{~g}$ & 0.02 & $s b-136 g$ & 3.45 \\
\hline $\mathrm{Ag}-128 \mathrm{~g}$ & 0.01 & $\mathrm{Te}-136 \mathrm{~g}$ & 0.19 \\
\hline $\mathrm{In}-129 \mathrm{~g}$ & 0.08 & $\mathrm{Sb}-137 \mathrm{~g}$ & 0.35 \\
\hline $\mathrm{Cd}-130 \mathrm{~g}$ & 0.01 & $\mathrm{Te}-137 \mathrm{~g}$ & 0.85 \\
\hline $\mathrm{In}-130 \mathrm{~g}$ & 0.09 & $\mathrm{I}-137 \mathrm{~g}$ & 0.70 \\
\hline $\mathrm{In}-130 \mathrm{~m}$ & 0.14 & $s b-138 g$ & 0.01 \\
\hline $\mathrm{cd}-131 \mathrm{~g}$ & 0.04 & $\mathrm{Te}-138 \mathrm{~g}$ & 1.64 \\
\hline $\mathrm{In}-131 \mathrm{~g}$ & 0.24 & $\mathrm{I}-138 \mathrm{~g}$ & 1.78 \\
\hline $\mathrm{In}-131 \mathrm{~m}$ & 0.56 & $\mathrm{Te}-139 \mathrm{~g}$ & 0.49 \\
\hline $\mathrm{Cd}-132 \mathrm{~g}$ & 0.02 & $\mathrm{I}-139 \mathrm{~g}$ & 5.18 \\
\hline $\mathrm{In}-132 \mathrm{~g}$ & 1.02 & $\mathrm{Te}-140 \mathrm{~g}$ & 0.16 \\
\hline In $-133 \mathrm{~g}$ & 1.16 & $\mathrm{I}-140 \mathrm{~g}$ & 3.12 \\
\hline$s n-133 g$ & 0.05 & $\mathrm{Te}-141 \mathrm{~g}$ & 0.01 \\
\hline $\mathrm{In}-134 \mathrm{~g}$ & 0.09 & $\mathrm{I}-141 \mathrm{~g}$ & 1.85 \\
\hline $\mathrm{Sn}-134 \mathrm{~g}$ & 1.33 & $\mathrm{Xe}-14 \mathrm{lg}$ & 0.03 \\
\hline $\mathrm{Sn}-135 \mathrm{~g}$ & 0.17 & $\mathrm{I}-142 \mathrm{~g}$ & 0.06 \\
\hline$s b-135 g$ & 2.94 & $x e-142 g$ & 0.21 \\
\hline$s n-136 g$ & 0.02 & $\mathrm{Cs}-142 \mathrm{~g}$ & 0.10 \\
\hline$S b-136 g$ & 2.47 & $I-143 g$ & 0.08 \\
\hline $\mathrm{Te}-136 \mathrm{~g}$ & 0.06 & $\mathrm{Xe}-143 \mathrm{~g}$ & 0.24 \\
\hline$S b-137 g$ & 0.46 & $\mathrm{Cs}-143 \mathrm{~g}$ & 1.47 \\
\hline $\mathrm{Te}-137 \mathrm{~g}$ & 0.32 & $\mathrm{Xe}-144 \mathrm{~g}$ & 0.22 \\
\hline$I-137 g$ & 0.20 & $\mathrm{Cs}-144 \mathrm{~g}$ & 1.78 \\
\hline$S b-138 g$ & 0.17 & $x e-145 g$ & 0.05 \\
\hline $\mathrm{Te}-138 \mathrm{~g}$ & 0.78 & $\mathrm{Cs}-145 \mathrm{~g}$ & 4.19 \\
\hline $\mathrm{I}-138 \mathrm{~g}$ & 0.56 & $\mathrm{Cs}-146 \mathrm{~g}$ & 0.65 \\
\hline$S b-139 g$ & 0.02 & $\mathrm{Cs}-147 \mathrm{~g}$ & 0.11 \\
\hline $\mathrm{Te}-139 \mathrm{~g}$ & 0.50 & $\mathrm{La}-148 \mathrm{~g}$ & 0.05 \\
\hline$I-139 g$ & 2.04 & $\mathrm{La}-149 \mathrm{~g}$ & 0.14 \\
\hline $\mathrm{Te}-140 \mathrm{~g}$ & 0.11 & $\mathrm{Ba}-150 \mathrm{~g}$ & 0.01 \\
\hline $\mathrm{I}-140 \mathrm{~g}$ & 2.12 & $\mathrm{La}-150 \mathrm{~g}$ & 0.02 \\
\hline $\mathrm{Te}-141 \mathrm{~g}$ & 0.05 & $\mathrm{La}-151 \mathrm{~g}$ & 0.07 \\
\hline $\mathrm{I}-141 \mathrm{~g}$ & 2.49 & $\operatorname{Pr}-155 \mathrm{~g}$ & 0.01 \\
\hline $\mathrm{Xe}-141 \mathrm{~g}$ & 0.01 & & \\
\hline $\mathrm{I}-142 \mathrm{~g}$ & 0.55 & & \\
\hline $\mathrm{xe}-142 \mathrm{~g}$ & 0.11 & & \\
\hline $\mathrm{Cs}-142 \mathrm{~g}$ & 0.04 & & \\
\hline$I-143 g$ & 0.14 & & \\
\hline$x e-143 g$ & 0.15 & & \\
\hline $\mathrm{Cs}-143 \mathrm{~g}$ & 0.61 & & \\
\hline
\end{tabular}

$(5.0 s)$

$(10.0 \mathrm{~s})$

$(30.0 s)$
Nuclide of Nuclide \& $\begin{array}{ll}\text { Nuclide } & z \\ \text { Cs-143g } & 1.86 \\ \mathrm{Xe}-144 \mathrm{~g} & 0.10 \\ \mathrm{Cs}-144 \mathrm{~g} & 0.78 \\ \mathrm{Xe}-145 \mathrm{~g} & 0.01 \\ \mathrm{Cs}-145 \mathrm{~g} & 0.27 \\ \mathrm{La}-147 \mathrm{~g} & 0.03 \\ \mathrm{La}-148 \mathrm{~g} & 0.04 \\ \mathrm{La}-149 \mathrm{~g} & 0.25\end{array}$

Nuclide 
Table B-IV (Cont.)
$(0.0 s)$
$(1.05)$
$(5.0 s)$
$(10.0 s)$
$(30.0 s)$

Nuclide \& Nuclide 8 Nuclide $\&$ Nuclide $\&$ Nuclide $q$

$\mathrm{Xe}-144 \mathrm{~g} \quad 0.13$

$\mathrm{Cs}-144 \mathrm{~g} \quad 1.04$

$\mathrm{Xe}-145 \mathrm{~g} \quad 0.03$

Cs-145g 4.12

Cs $-146 \mathrm{~g} \quad 1.54$

Cs $-147 \mathrm{~g} \quad 0.13$

Cs-148g 0.04

$\mathrm{La}-148 \mathrm{~g} \quad 0.02$

$\mathrm{La}-149 \mathrm{~g} \quad 0.06$

La-150g 0.02

La-15lg 0.06

\section{TABLE V \\ 238U FISSION PULSE}

PER CENT CONTRIBUTION PER PRECURSOR GREATER THAN $0.01 \%$

FOR ENERGIES ABOVE $4.0 \mathrm{MeV}$
$(0.0 s)$
(1.0s)
$(5.0 s)$
$(10.0 s)$
$(30.0 s)$

\begin{tabular}{|c|c|c|c|c|c|c|c|c|c|}
\hline Nuclide & 8 & Nuclide & 8 & Nuclide & 8 & Nuclide & 8 & Nuclide & s \\
\hline $\mathrm{Ga}-83 \mathrm{~g}$ & 0.02 & $\mathrm{Ga}-83 \mathrm{~g}$ & 0.02 & $\mathrm{Ga}-82 \mathrm{~g}$ & 0.02 & As- $85 \mathrm{~g}$ & 30.47 & $A s-85 g$ & 66.69 \\
\hline $\mathrm{Ga}-84 \mathrm{~g}$ & 0.02 & $A s-86 g$ & 0.05 & $A s-85 g$ & 1.43 & As $-86 \mathrm{~g}$ & 3.58 & $\mathrm{Br}-90 \mathrm{~g}$ & 33.30 \\
\hline $\mathrm{Ge}-85 \mathrm{~g}$ & 0.01 & As $-87 \mathrm{~g}$ & 0.09 & $A s-86 \mathrm{~g}$ & 1.43 & $\mathrm{Br}-90 \mathrm{~g}$ & 36.41 & & \\
\hline$A s-86 g$ & 0.01 & Se- $89 \mathrm{~g}$ & 0.01 & $\mathrm{Se}-89 \mathrm{~g}$ & 0.01 & $\mathrm{Br}-91 \mathrm{~g}$ & 23.04 & & \\
\hline As- $87 \mathrm{~g}$ & 0.13 & $\mathrm{Br}-90 \mathrm{~g}$ & 0.01 & $\mathrm{Br}-90 \mathrm{~g}$ & 2,12 & $\mathrm{Br}-92 \mathrm{~g}$ & 0.21 & & \\
\hline As- $88 \mathrm{~g}$ & 0.03 & $\mathrm{Br}-91 \mathrm{~g}$ & 9.52 & $\mathrm{Br}-91 \mathrm{~g}$ & 63.24 & $\mathrm{Kr}-95 \mathrm{~g}$ & 0.06 & & \\
\hline As- $89 \mathrm{~g}$ & 0.02 & $\mathrm{Br}-92 \mathrm{~g}$ & 88.15 & $\mathrm{Br}-92 \mathrm{~g}$ & 26.74 & $\mathrm{Rb}-95 \mathrm{~g}$ & 3.20 & & \\
\hline $\mathrm{Se}-89 \mathrm{~g}$ & 0.01 & $\mathrm{Rb}-95 \mathrm{~g}$ & 0.79 & $\mathrm{Kr}-95 \mathrm{~g}$ & 0.04 & $\mathrm{I}-140 \mathrm{~g}$ & 2.97 & & \\
\hline $\mathrm{Se}-91 \mathrm{~g}$ & 0.01 & $R b-96 \mathrm{~g}$ & 0.51 & $R b-95 g$ & 2.62 & $\mathrm{I}-14 \mathrm{Ig}$ & 0.07 & & \\
\hline $\mathrm{Br}-91 \mathrm{~g}$ & 4.42 & $R b-97 g$ & 0.10 & $\mathrm{I}-140 \mathrm{~g}$ & 1.25 & & & & \\
\hline $\mathrm{Br}-92 \mathrm{~g}$ & 89.28 & $R b-98 g$ & 0.02 & $\mathrm{I}-141 \mathrm{~g}$ & 1.05 & & & & \\
\hline $\mathrm{Br}-93 \mathrm{~g}$ & 0.07 & $\mathrm{I}-140 \mathrm{~g}$ & 0.04 & $\mathrm{Cs}-147 \mathrm{~g}$ & 0.03 & & & & \\
\hline $\mathrm{Br}-94 \mathrm{~g}$ & 0.02 & $\mathrm{I}-141 \mathrm{~g}$ & 0.64 & & & & & & \\
\hline$R b-95 g$ & 0.67 & & & & & & & & \\
\hline $\mathrm{Rb}-96 \mathrm{~g}$ & 2.01 & & & & & & & & \\
\hline $\mathrm{Rb}-97 \mathrm{~g}$ & 0.86 & & & & & & & & \\
\hline $\mathrm{Rb}-98 \mathrm{~g}$ & 1.92 & & & & & & & & \\
\hline$I n-133 g$ & 0.02 & & & & & & & & \\
\hline $\mathrm{I}-140 \mathrm{~g}$ & 0.01 & & & & & & & & \\
\hline$I-141 \mathrm{~g}$ & 0.41 & & & & & & & & \\
\hline
\end{tabular}



FOR ENERGIES ABOVE $0.0 \mathrm{MeV}$

$(0.0 s)$

$\begin{array}{lr}\mathrm{NuCl} i \mathrm{de} & 8 \\ \mathrm{Ga}-80 \mathrm{~g} & 0.01 \\ \mathrm{Ga}-81 \mathrm{~g} & 0.08 \\ \mathrm{Ga}-82 \mathrm{~g} & 0.06 \\ \mathrm{Ga}-83 \mathrm{~g} & 0.04 \\ \mathrm{Ge}-84 \mathrm{~g} & 0.06 \\ \mathrm{As}-84 \mathrm{~g} & 0.04 \\ \mathrm{Ge}-85 \mathrm{~g} & 0.11 \\ \mathrm{As}-85 \mathrm{~g} & 4.50 \\ \mathrm{As}-86 \mathrm{~g} & 0.33 \\ \mathrm{As}-87 \mathrm{~g} & 0.92 \\ \mathrm{Se}-87 \mathrm{~g} & 0.01 \\ \mathrm{Br}-87 \mathrm{~g} & 0.06 \\ \mathrm{As}-88 \mathrm{~g} & 0.08 \\ \mathrm{Se}-88 \mathrm{~g} & 0.10 \\ \mathrm{Br}-88 \mathrm{~g} & 0.52 \\ \mathrm{Se}-89 \mathrm{~g} & 0.52 \\ \mathrm{Br}-89 \mathrm{~g} & 2.68 \\ \mathrm{Se}-90 \mathrm{~g} & 0.08 \\ \mathrm{Br}-90 \mathrm{~g} & 4.41 \\ \mathrm{Se}-91 \mathrm{~g} & 0.03 \\ \mathrm{Br}-91 \mathrm{~g} & 2.75 \\ \mathrm{Br}-92 \mathrm{~g} & 1.68 \\ \mathrm{Kr}-92 \mathrm{~g} & 0.02 \\ \mathrm{Br}-93 \mathrm{~g} & 0.19 \\ \mathrm{Kr}-93 \mathrm{~g} & 0.54 \\ \mathrm{Rb}-93 \mathrm{~g} & 0.83 \\ \mathrm{Br}-94 \mathrm{~g} & 0.02 \\ \mathrm{Kr}-94 \mathrm{~g} & 1.92 \\ \mathrm{Rb}-94 \mathrm{~g} & 6.68 \\ \mathrm{Kr}-95 \mathrm{~g} & 0.07 \\ \mathrm{Rb}-95 \mathrm{~g} & 17.11 \\ \mathrm{Kr}-96 \mathrm{~g} & 0.02 \\ \mathrm{Rb}-96 \mathrm{~g} & 11.51 \\ \mathrm{Rb}-97 \mathrm{~g} & 4.14 \\ \mathrm{Sr}-97 \mathrm{~g} & 0.03 \\ \mathrm{Y}-97 \mathrm{~g} & 0.05 \\ \mathrm{Y}-97 \mathrm{~m} & 0.37 \\ \mathrm{Rb}-98 \mathrm{~g} & 0.28 \\ \mathrm{Sr}-98 \mathrm{~g} & 0.31 \\ \mathrm{Y}-98 \mathrm{~g} & 0.32 \\ \mathrm{~B}-94 \mathrm{~g} & 0.01 \\ & \end{array}$

(1.0s)

Nuclide

$\mathrm{Ga}-80 \mathrm{~g} 0.02$

$\mathrm{Ga}-81 \mathrm{~g} \quad 0.11$

$\mathrm{Ga}-82 \mathrm{~g} \quad 0.05$

$\mathrm{Ga}-83 \mathrm{~g}$

0.01

$\mathrm{Ge}-84 \mathrm{~g}$

0.08

As $-84 \mathrm{~g}$

$\mathrm{Ge}-85 \mathrm{~g}$

0.01

As- $85 \mathrm{~g}$

0.02

As - $86 \mathrm{~g}$

7.93

As $-87 \mathrm{~g}$

0.37

$\mathrm{Se}-87 \mathrm{~g}$

0.22

$\mathrm{Br}-87 \mathrm{~g}$

0.03

$\mathrm{Se}-88 \mathrm{~g}$

$\mathrm{Br}-88 \mathrm{~g}$

0.16

0.15

$\mathrm{Se}-89 \mathrm{~g}$

$\mathrm{Br}-89 \mathrm{~g}$

$\mathrm{Se}-90 \mathrm{~g}$

$\mathrm{Br}-90 \mathrm{~g}$

$\mathrm{Br}-91 \mathrm{~g}$

$\mathrm{Br}-92 \mathrm{~g}$

$\mathrm{Kr}-92 \mathrm{~g}$

$R b-92 g$

$\mathrm{Kr}-93 \mathrm{~g}$

$R b-93 g$

$\mathrm{Kr}-94 \mathrm{~g}$

$\mathrm{Rb}-94 \mathrm{~g} 13.18$

$\mathrm{K}_{\mathrm{i}}-95 \mathrm{~g} \quad 0.07$

$\mathrm{Rb}-95 \mathrm{~g} \quad 6.86$

$\mathrm{Rb}-96 \mathrm{~g} \quad 0.96$

$\mathrm{Rb}-97 \mathrm{~g}$

$\mathrm{Sr}-97 \mathrm{~g}$

$Y-97 \mathrm{~g}$

$Y-97 \mathrm{~m}$

Sr- $98 \mathrm{~g}$

$Y-98 \mathrm{~g}$

$Y-98 \mathrm{~m} 15.14$

SI- $99 \mathrm{~g} \quad 0.02$

$\mathrm{Y}-99 \mathrm{~g}$

$\mathrm{S} r-100 \mathrm{~g}$

$\mathrm{Y}-100 \mathrm{~g}$

$Y-101 \mathrm{~g}$

$\mathrm{Y}-102 \mathrm{~g}$

\section{$(5.05)$}

Nuclide

$\mathrm{Ga}-80 \mathrm{~g} \quad 0.01$

$\mathrm{Ga}-81 \mathrm{~g} \quad 0.04$

$\mathrm{Ge}-84 \mathrm{~g} \quad 0.03$

As $-85 \mathrm{~g} 8.05$

As - $86 \mathrm{~g} \quad 0.07$

Se- $87 \mathrm{~g} \quad 0.08$

$\mathrm{Br}-87 \mathrm{~g} \quad 0.68$

$\mathrm{Se}-88 \mathrm{~g} \quad 0.09$

$\mathrm{BI}-88 \mathrm{~g} \quad 4.48$

$\mathrm{Br}-89 \mathrm{~g} \quad 12.24$

$\mathrm{Br}-90 \mathrm{~g} \quad 6.34$

$\mathrm{Br}-91 \mathrm{~g} \quad 0.08$

$\mathrm{Kr}-92 \mathrm{~g} \quad 0.03$

$\mathrm{Rb}-92 \mathrm{~g} \quad 0.05$

$\mathrm{Kr}-93 \mathrm{~g} \quad 0.36$

$\mathrm{Rb}-93 \mathrm{~g} 4.92$

$\mathrm{Rb}-94 \mathrm{~g} 19.20$

$\mathrm{Rb}-95 \mathrm{~g} \quad 0.04$

$\begin{array}{lll}Y-97 \mathrm{~g} & 0.33\end{array}$

$Y-97 \mathrm{~m} \quad 0.17$

Sr- $98 \mathrm{~g} \quad 0.01$

$Y-98 g$

0.54

$Y-98 \mathrm{~m}$

1.50

$Y-99 \mathrm{~g}$

$\mathrm{Y}-100 \mathrm{~g}$

3.90

$Y-101 \mathrm{~g}$

$\mathrm{Y}-102 \mathrm{~g}$

0.17

0.04

$\mathrm{Zr}-103 \mathrm{~g}$

0.08

$\mathrm{Nb}-103 \mathrm{~g}$

2r-104g

$\mathrm{Nb}-104 \mathrm{~g}$

$\mathrm{Nb}-105 \mathrm{~g}$

$\mathrm{Nb}-106 \mathrm{~g}$

$\mathrm{Nb}-107 \mathrm{~g}$

Tc- $109 \mathrm{~g}$

Tc-111g

$\mathrm{Rh}-115 \mathrm{~g}$

In-127g

In-129g

In $-129 \mathrm{~m}$

$\mathrm{sn}-134 \mathrm{~g}$

$\mathrm{Sb}-134 \mathrm{~g}$
$(10.0 s)$

Nuclide

As- $85 \mathrm{~g} \quad 3.54$

$\mathrm{Se}-87 \mathrm{~g} \quad 0.10$

$\mathrm{Br}-87 \mathrm{~g} \quad 1.66$

$\mathrm{Se}-88 \mathrm{~g} \quad 0.02$

$\mathrm{Br}-88 \mathrm{~g} \quad 8.87$

$\mathrm{Br}-89 \mathrm{~g} \quad 13.48$

$\mathrm{Br}-90 \mathrm{~g} \quad 2.25$

$\mathrm{Kr}-92 \mathrm{~g} \quad 0.01$

$\mathrm{Rb}-92 \mathrm{~g} \quad 0.07$

$\mathrm{Kr}-93 \mathrm{~g} \quad 0.06$

$\mathrm{Rb}-93 \mathrm{~g} \quad 6.69$

$\mathrm{Rb}-94 \mathrm{~g} 13.28$

Y- $97 \mathrm{~g} \quad 0.31$

$Y-97 \mathrm{~m} \quad 0.02$

$Y-98 \mathrm{~g} \quad 0.23$

$Y-98 \mathrm{~m} \quad 0.03$

$Y-99 \mathrm{~g} \quad 0.80$

$\mathrm{Nb}-103 \mathrm{~g} \quad 0.03$

$2 r-104 g \quad 0.03$

$\mathrm{Nb}-104 \mathrm{~g} \quad 0.14$

$\mathrm{Nb}-105 \mathrm{~g} \quad 2.50$

Tc-111g 0.03

Rh-115g 0.03

In $-127 \mathrm{~g} \quad 0.13$

In $-129 \mathrm{~m} \quad 0.04$

sb-134g 0.04

$\mathrm{Sb}-135 \mathrm{~g} \quad 0.47$

$\mathrm{Te}-136 \mathrm{~g} \quad 1.27$

$\mathrm{Te}-137 \mathrm{~g} \quad 0.54$

$I-137 \mathrm{~g} \quad 22.67$

Te-138g 0.06

$I-138 \mathrm{~g} \quad 17.30$

$\mathrm{I}-139 \mathrm{~g} \quad 2.18$

Cs-141g 0.25

$\mathrm{Cs}-142 \mathrm{~g} \quad 0.08$

$\mathrm{Cs}-143 \mathrm{~g} \quad 0.57$

$\mathrm{Cs}-144 \mathrm{~g} \quad 0.02$

$\mathrm{La}-146 \mathrm{~g} \quad 0.01$

$\mathrm{La}-147 \mathrm{~g} \quad 0.05$

$\mathrm{La}-149 \mathrm{~g} \quad 0.04$
$(30.0 s)$

Nuclide $\frac{}{8}$

As- $85 \mathrm{~g} \quad 0.02$

$\mathrm{Se}-87 \mathrm{~g} \quad 0.04$

$\mathrm{Br}-87 \mathrm{~g} \quad 6.28$

$\mathrm{Br}-88 \mathrm{~g} \quad 16.74$

$\mathrm{BI}-89 \mathrm{~g} \quad 2.55$

$\mathrm{Rb}-92 \mathrm{~g} \quad 0.01$

$\mathrm{Rb}-93 \mathrm{~g} \quad 2 . \varepsilon 2$

$\mathrm{Rb}-94 \mathrm{~g} \quad 0.39$

$Y-97 \mathrm{~g} \quad 0.03$

$\mathrm{Nb}-104 \mathrm{~g} \quad 0.04$

$\mathrm{Nb}-10.5 \mathrm{~g} \quad 0.08$

Rh-115g 0.02

In $-127 \mathrm{~g} \quad 0.02$

$\mathrm{Sb}-134 \mathrm{~g} \quad 0.04$

Te-136g 2.74

Te-137g 0.05

$\mathrm{I}-137 \mathrm{~g} \quad 58.24$

$\mathrm{I}-138 \mathrm{~g} \quad 9.19$

$\mathrm{I}-139 \mathrm{~g} \quad 0.03$

Cs-141g 0.64

$\mathrm{La}-146 \mathrm{~g} \quad 0.02$

La-147g 0.01

Continued 
Table B-VI (Cont.)

$$
(0.05)
$$

$$
(1.05)
$$

$(5.0 s)$

$(10.0 \mathrm{~s})$

\begin{tabular}{|c|c|c|c|c|c|}
\hline Nuclide & \& & Nuclide & 8 & Nuclide & $\frac{2}{6}$ \\
\hline$S I-99 g$ & 0.02 & $Y-103 g$ & 0.06 & $5 b-135 g$ & 1.31 \\
\hline$Y-99 g$ & 4.50 & $\mathrm{zr}-103 \mathrm{~g}$ & 0.03 & $\mathrm{sb}-136 \mathrm{~g}$ & 0.04 \\
\hline $5 r-100 g$ & 0.02 & $\mathrm{Nb}-103 \mathrm{~g}$ & 0.13 & $\mathrm{Te}-136 \mathrm{~g}$ & 0.63 \\
\hline$Y-100 g$ & 1.31 & $\mathrm{Zr}-104 \mathrm{~g}$ & 0.04 & $\mathrm{Te}-137 \mathrm{~g}$ & 0.60 \\
\hline $5 r-101 g$ & 0.02 & $\mathrm{Nb}-104 \mathrm{~g}$ & 0.05 & $\mathrm{I}-137 \mathrm{~g}$ & 10.61 \\
\hline$Y-101 \mathrm{~g}$ & 1.12 & $\mathrm{zr}-105 \mathrm{~g}$ & 0.04 & $\mathrm{Te}-138 \mathrm{~g}$ & 0.22 \\
\hline$Y-102 \mathrm{~g}$ & 0.38 & $\mathrm{Nb}-105 \mathrm{~g}$ & 2.39 & $\mathrm{I}-138 \mathrm{~g}$ & 12.10 \\
\hline$Y-103 g$ & 0.36 & $\mathrm{Nb}-106 \mathrm{~g}$ & 0.35 & $\mathrm{I}-139 \mathrm{~g}$ & 3.85 \\
\hline $2 r-103 g$ & 0.02 & $\mathrm{Nb}-107 \mathrm{~g}$ & 0.34 & $\mathrm{I}-140 \mathrm{~g}$ & 0.12 \\
\hline $\mathrm{Nb}-103 \mathrm{~g}$ & 0.08 & $\mathrm{Tc}-109 \mathrm{~g}$ & 0.06 & $\mathrm{xe}-14 \mathrm{lg}$ & 0.03 \\
\hline$Y-104 g$ & 0.04 & $\mathrm{Tc}-110 \mathrm{~g}$ & 0.06 & $C s-141 \mathrm{~g}$ & 0.12 \\
\hline $2 x-104 g$ & 0.02 & $\mathrm{Tc}-111 \mathrm{~g}$ & 0.06 & $\mathrm{xe}-142 \mathrm{~g}$ & 0.04 \\
\hline $\mathrm{Nb}-104 \mathrm{~g}$ & 0.02 & $\mathrm{Rh}-117 \mathrm{~g}$ & 0.01 & $C s-142 \mathrm{~g}$ & 0.25 \\
\hline$z x-105 g$ & 0.06 & In-127g & 0.07 & $c s-143 g$ & 1.63 \\
\hline $\mathrm{Nb}-105 \mathrm{~g}$ & 1.23 & In $-128 \mathrm{~g}$ & 0.01 & $\mathrm{Cs}-144 \mathrm{~g}$ & 0.27 \\
\hline $\mathrm{Nb}-106 \mathrm{~g}$ & 0.29 & In $-129 \mathrm{~g}$ & 0.32 & $\mathrm{Cs}-145 \mathrm{~g}$ & 0.03 \\
\hline $\mathrm{Nb}-107 \mathrm{~g}$ & 0.34 & $I_{n-129 m}$ & 0.05 & $\mathrm{La}-147 \mathrm{~g}$ & 0.04 \\
\hline $\mathrm{Nb}-108 \mathrm{~g}$ & 0.01 & $\mathrm{In}-130 \mathrm{~g}$ & 0.09 & $\mathrm{La}-148 \mathrm{~g}$ & 0.02 \\
\hline $\mathrm{Tc}-109 \mathrm{~g}$ & 0.04 & In-130m & 0.06 & $\mathrm{La}-149 \mathrm{~g}$ & 0.07 \\
\hline $\mathrm{Tc}-110 \mathrm{~g}$ & 0.96 & In-13lg & 0.02 & & \\
\hline $\mathrm{Tc}=111 \mathrm{~g}$ & 0.04 & $S n-133 g$ & 0.02 & & \\
\hline $\mathrm{Tc}-112 \mathrm{~g}$ & 0.02 & $S n-134 g$ & 0.08 & & \\
\hline $\mathrm{Rh}-117 \mathrm{~g}$ & 0.01 & $S b-135 g$ & 1.51 & & \\
\hline $\mathrm{Ag}-124 \mathrm{~g}$ & 0.03 & $\mathrm{Sb}-136 \mathrm{~g}$ & 0.27 & & \\
\hline $\mathrm{Ag}-125 \mathrm{~g}$ & 0.01 & $\mathrm{Te}-136 \mathrm{~g}$ & 0.18 & & \\
\hline $\mathrm{In}-127 \mathrm{~g}$ & 0.03 & $\mathrm{Te}-137 \mathrm{~g}$ & 0.33 & & \\
\hline$I n-128 g$ & 0.01 & $\mathrm{I}-137 \mathrm{~g}$ & 2.92 & & \\
\hline $\mathrm{In}-129 \mathrm{~g}$ & 0.26 & $\mathrm{Te}-138 \mathrm{~g}$ & 0.32 & & \\
\hline $\mathrm{In}-129 \mathrm{~m}$ & 0.03 & $\mathrm{I}-138 \mathrm{~g}$ & 4.61 & & \\
\hline In $-130 \mathrm{~g}$ & 0.05 & $\mathrm{Te}-139 \mathrm{~g}$ & 0.02 & & \\
\hline In-130m & 0.08 & $I-139 \mathrm{~g}$ & 3.10 & & \\
\hline In-131g & 0.04 & $\mathrm{I}-140 \mathrm{~g}$ & 0.74 & & \\
\hline In-131m & 0.10 & $I-14=3$ & 0.16 & & \\
\hline In-132g & 0.05 & $\mathrm{Xe}-14 \mathrm{lg}$ & 0.03 & & \\
\hline In-133g & 0.01 & $\mathrm{Cs}_{3}-14 \mathrm{lg}$ & 0.03 & & \\
\hline $5 n-133 g$ & 0.01 & $\mathrm{Xe}-142 \mathrm{~g}$ & 0.09 & & \\
\hline $5 n-134 g$ & 0.07 & $\mathrm{Cs}_{3}-142 \mathrm{~g}$ & 0.31 & & \\
\hline $5 b-135 g$ & 0.90 & $\mathrm{Xe}-143 \mathrm{~g}$ & 0.04 & & \\
\hline $\mathrm{Sb}-136 \mathrm{~g}$ & 0.25 & $\mathrm{Cs}-143 \mathrm{~g}$ & 1.92 & & \\
\hline $\mathrm{Te}-136 \mathrm{~g}$ & 0.08 & $C s-144 g$ & 3.07 & & \\
\hline $\mathrm{Sb}-137 \mathrm{~g}$ & 0.02 & $\mathrm{Cs}_{s}-145 \mathrm{~g}$ & 0.69 & & \\
\hline $\mathrm{Te}-137 \mathrm{~g}$ & 0.17 & $\mathrm{Cs}-146 \mathrm{~g}$ & 0.04 & & \\
\hline$I-137 g$ & 1.22 & $\mathrm{La}-147 \mathrm{~g}$ & 0.02 & & \\
\hline $\mathrm{Te}-138 \mathrm{~g}$ & 0.20 & $\mathrm{La}-148 \mathrm{~g}$ & 0.05 & & \\
\hline$I-138 g$ & 2.08 & $\mathrm{La}-149 \mathrm{~g}$ & 0.05 & & \\
\hline
\end{tabular}

$(30.0 \mathrm{~s})$
Nuclide 8 Nuclide 8

Continued 
Table B-VI (Cont.)
$(0.05)$
$(1.05)$
$(5.05)$
$(10.0 s)$
$(30.0 s)$

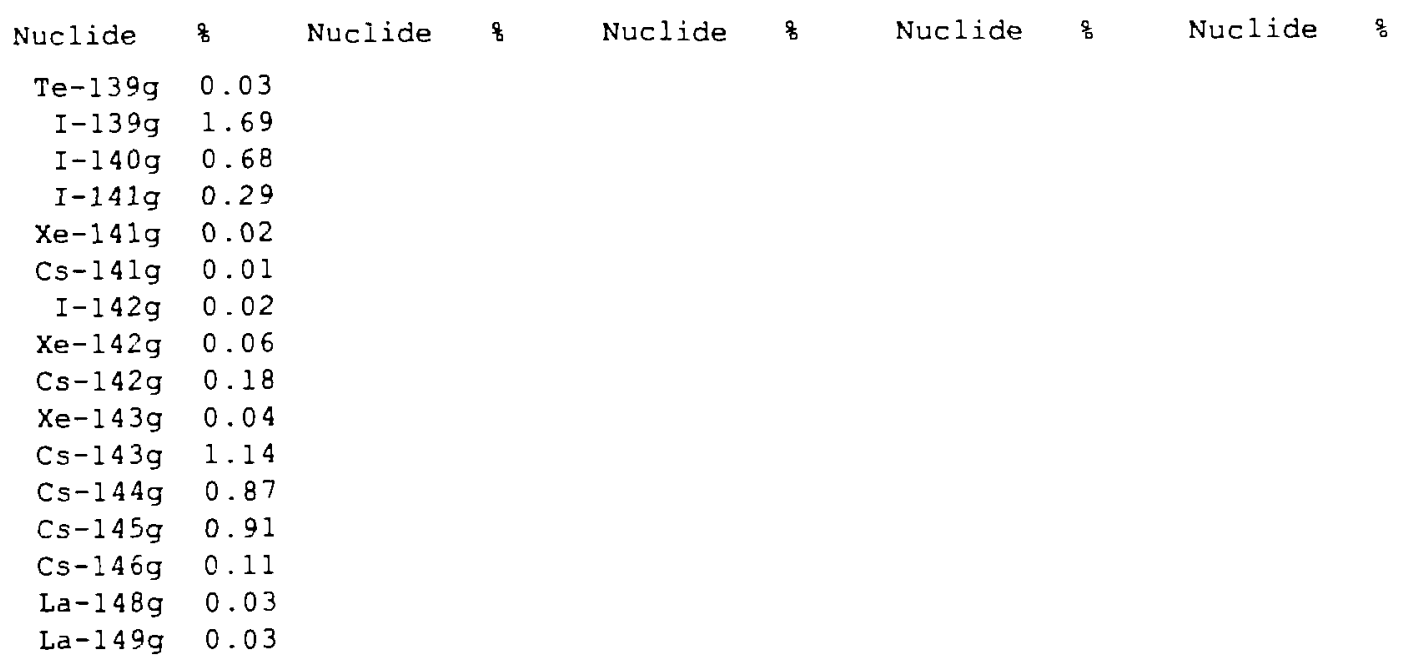

TABLE B-VII

${ }^{239} \mathrm{Pu}$ FISSION PULSE

PER CENT CONTRIBUTION PER PRECURSOR GREATER THAN $0.01 \%$ FOR ENERGIES ABOVE $4.0 \mathrm{MeV}$
$(0.0 s)$
$(1.0 s\}$
$(5.0 s)$
$(10.05)$
$(30.05)$

\begin{tabular}{|c|c|c|c|c|c|c|c|c|}
\hline Nuclide & $\underline{z}$ & Nuclide & $\frac{2}{5}$ & Nuclide & $\varepsilon$ & Nuclide & 实 & Nuclide \\
\hline $\mathrm{Ga}-83 \mathrm{~g}$ & 0.01 & As - $85 q$ & 0.03 & $\mathrm{Ga}-32 \mathrm{~g}$ & 0.02 & As $-85 g$ & 43.42 & $A s-85 g 72.37$ \\
\hline A.s $=86 \mathrm{~g}$ & 0.03 & $A s-86 g$ & 0.08 & As $-85 g$ & 3.97 & As $-86 \mathrm{~g}$ & 2.32 & $\mathrm{Br}-90 \mathrm{~g} 27.62$ \\
\hline As- $87 \mathrm{~g}$ & 0.17 & As $-87 \mathrm{~g}$ & 0.11 & As $-86 g$ & 1.81 & $\mathrm{Br}-90 \mathrm{~g}$ & 39.66 & \\
\hline As $-88 \mathrm{~g}$ & 0.01 & $\mathrm{Se}-89 \mathrm{~g}$ & 0.01 & $\mathrm{Br}-90 \mathrm{~g}$ & 4.51 & $\mathrm{Br}-91 \mathrm{~g}$ & 12.99 & \\
\hline $\mathrm{Se}-89 \mathrm{~g}$ & 0.01 & $B r-90 g$ & 0.04 & $\mathrm{Br}-9 \mathrm{lg}$ & 69.44 & $\mathrm{Br}-92 \mathrm{~g}$ & 0.07 & \\
\hline $\mathrm{Br}-91 \mathrm{~g}$ & $7.0 n$ & $\mathrm{Br}-91 \mathrm{~g}$ & 14.84 & $\mathrm{Br}-92 \mathrm{~g}$ & 17.16 & $k r-95 g$ & 0.01 & \\
\hline$B r-92 g$ & 81.60 & $\mathrm{Br}-92 \mathrm{~g}$ & 79.93 & $k r-95 g$ & 0.02 & $P b-95 g$ & 0.79 & \\
\hline$B r-93 g$ & 0.03 & $\mathrm{Rb}-95 \mathrm{~g}$ & 3.38 & $R b-95 g$ & 2.16 & $\mathrm{I}-140 \mathrm{~g}$ & 0.72 & \\
\hline $\mathrm{Rb}-95 \mathrm{~g}$ & 3.08 & $R b-96 \mathrm{~g}$ & 1.03 & $\mathrm{I}=140 \mathrm{~g}$ & 0.67 & & & \\
\hline $\mathrm{Rb}-96 \mathrm{~g}$ & 4.53 & $\mathrm{Rb}-97 \mathrm{~g}$ & 0.27 & $\mathrm{I}-141 \mathrm{~g}$ & 0.22 & & & \\
\hline$R b-97 g$ & 2.37 & $R b-98 g$ & 0.01 & & & & & \\
\hline$R b-98 g$ & 0.98 & $\mathrm{I}-140 \mathrm{~g}$ & 0.04 & & & & & \\
\hline $\mathrm{I}-140 \mathrm{~g}$ & 0.01 & $\mathrm{I}-141 \mathrm{~g}$ & 0.19 & & & & & \\
\hline$I-141 g$ & 0.13 & & & & & & & \\
\hline
\end{tabular}


TABIE B-VIII

232Th FISSION PULSE

PER CENT CONTRIBUTION PER PRECURSOR GREATER THAN $0.01 \%$ FOR ENERGIES ABOVE $0.0 \mathrm{MeV}$

\section{$(0.05)$}

\begin{tabular}{|c|c|c|c|}
\hline lide & \& & Nuclide & 8 \\
\hline$-79 g$ & 0.01 & $\mathrm{Ga}-80 \mathrm{~g}$ & 0.01 \\
\hline$-81 g$ & 0.03 & $\mathrm{Ga}-\mathrm{BIg}$ & 0.24 \\
\hline-819 & 0.15 & $\mathrm{Ga}-82 \mathrm{~g}$ & 0.28 \\
\hline$-82 g$ & 0.03 & $\mathrm{Ga}-83 \mathrm{~g}$ & 0.24 \\
\hline$a-82 g$ & 0.32 & $\mathrm{Ge}-84 \mathrm{~g}$ & 0.99 \\
\hline$-83 g$ & 0.80 & $A s-84 g$ & 0.03 \\
\hline$g-84 g$ & 0.23 & $\mathrm{Ge}-85 \mathrm{~g}$ & 0.37 \\
\hline $2-84 g$ & 0.64 & As- $85 \mathrm{~g}$ & 22.26 \\
\hline $5-84 g$ & 0.05 & $\mathrm{Ge}-86 \mathrm{~g}$ & 0.07 \\
\hline$-85 g$ & 0.04 & $86 g$ & 1.80 \\
\hline$-85 g$ & 2.14 & $\mathrm{~s}-87 \mathrm{~g}$ & 2.18 \\
\hline$s-85 g$ & 10.38 & $\mathrm{Se}-87 \mathrm{~g}$ & 0.08 \\
\hline$e-86 g$ & 0.40 & $87 \mathrm{~g}$ & 0.07 \\
\hline$s-86 g$ & 1.35 & $A s-88 g$ & 0.02 \\
\hline$e-87 g$ & 0.06 & $S e-88 g$ & 0.70 \\
\hline$s-87 g$ & 7.86 & $\mathrm{Br}-88 \mathrm{~g}$ & 0.92 \\
\hline$e-87 g$ & 0.03 & Se- $89 g$ & 1.91 \\
\hline$r-87 g$ & 0.02 & $\mathrm{Br}-89 \mathrm{~g}$ & 7.10 \\
\hline$s-88 g$ & 1.23 & $\mathrm{Se}-90 \mathrm{~g}$ & 0.56 \\
\hline$e-88 g$ & 0.40 & $B r-90 g$ & 11.51 \\
\hline$=-88 g$ & 0.25 & e- $91 \mathrm{~g}$ & 0.10 \\
\hline$s-89 g$ & 0.30 & $\mathrm{Br}-91 \mathrm{~g}$ & 4.78 \\
\hline$e-89 g$ & 3.72 & $B I-92 g$ & 1.87 \\
\hline$=-89 g$ & 2.48 & $k r-92 g$ & 0.04 \\
\hline$e-90 g$ & 1.03 & $\mathrm{Br}-93 \mathrm{~g}$ & 0.06 \\
\hline$r-90 g$ & 5.60 & $K r-93 g$ & 1.23 \\
\hline $\mathrm{se}-91 \mathrm{~g}$ & 0.47 & $\mathrm{Rb}-93 \mathrm{~g}$ & 0.52 \\
\hline $3=-91 g$ & 5.35 & $\mathrm{Kr}-94 \mathrm{~g}$ & 0.49 \\
\hline$e-92 \mathrm{~g}$ & 0.04 & g- $94 \mathrm{~g}$ & 5.05 \\
\hline$r-92 \mathrm{~g}$ & 4.55 & $k r-95 g$ & 0.29 \\
\hline$r-92 g$ & 0.02 & $R b-95 g$ & 3.63 \\
\hline$r-93 g$ & 1.16 & $K r-96 g$ & 0.02 \\
\hline$r-93 g$ & 0.76 & $\mathrm{Rb}-96 \mathrm{~g}$ & 0.60 \\
\hline$b-93 \mathrm{~g}$ & 0.16 & $\mathrm{Rb}-97 \mathrm{~g}$ & 0.22 \\
\hline$r-94 g$ & 0.18 & $Y-97 g$ & 0.02 \\
\hline $\mathrm{r}-94 \mathrm{~g}$ & 4.74 & $Y-97 \mathrm{~m}$ & 0.03 \\
\hline$b-94 g$ & 1.79 & $\mathrm{Sr}-98 \mathrm{~g}$ & 0.15 \\
\hline$K r-95 g$ & 0.26 & $Y-98 \mathrm{~g}$ & 0.04 \\
\hline$R b-95 g$ & 7.28 & $\mathrm{Y}-98 \mathrm{~m}$ & 2.52 \\
\hline $\mathrm{Kr}-96 \mathrm{~g}$ & 0.08 & Sr- $99 g$ & 0.01 \\
\hline $\mathrm{Rb}-96 \mathrm{~g}$ & 5.64 & $Y-99 g$ & 0.87 \\
\hline $\mathrm{KI}-97 \mathrm{~g}$ & 0.02 & $\mathrm{Sr}-100 \mathrm{~g}$ & 0.01 \\
\hline$b-97 g$ & 4.70 & $\mathrm{Y}-100 \mathrm{~g}$ & 0.10 \\
\hline$Y-97 m$ & 0.02 & $\mathrm{Y}-101 \mathrm{~g}$ & 0.07 \\
\hline
\end{tabular}

$(5.0 s)$

$(10.08)$

Nuclide 8 Nucljide

$\mathrm{Ga}-80 \mathrm{~g} \quad 0.01$

$\mathrm{Ga}-81 \mathrm{~g} \quad 0.12$

$\mathrm{Ga}-82 \mathrm{~g} \quad 0.01$

$\mathrm{Ge}-84 \mathrm{~g} \quad 0.45$

As- $85 \mathrm{~g} 26.22$

As- $86 \mathrm{~g} \quad 0.38$

$\mathrm{Se}-87 \mathrm{~g} \quad 0.22$

$\mathrm{Br}-87 \mathrm{~g} \quad 0.49$

Se- $88 \mathrm{~g} \quad 0.51$

$\mathrm{Br}-88 \mathrm{~g} \quad 5.02$

Se- $89 \mathrm{~g} \quad 0.01$

$\mathrm{Br}-89 \mathrm{~g} 18.10$

$\mathrm{Br}-90 \mathrm{~g} 11.69$

$\mathrm{Br}-91 \mathrm{~g} \quad 0.22$

$\mathrm{KI}-92 \mathrm{~g} \quad 0.04$

$\mathrm{Rb}-92 \mathrm{~g} \quad 0.02$

Kr- $93 \mathrm{~g} \quad 0.66$

$\mathrm{Rb}-93 \mathrm{~g} 2.03$

$\mathrm{Rb}-94 \mathrm{~g}$

8.57

$\mathrm{Kr}-95 \mathrm{~g}$

0.04

$\mathrm{Rb}-95 \mathrm{~g}$

0.09

$\mathrm{Y}-97 \mathrm{~g}$

$Y-97 m$

0.06

$Y-98 \mathrm{~g}$

0.02

$Y-98 m$

0.04

$Y-99 \mathrm{~g}$

0.60

$\mathrm{Y}-100 \mathrm{~g}$

$\mathrm{Nb}-105 \mathrm{~g}$

Tc-111g

In-129g

$\mathrm{Sn}-133 \mathrm{y}$

$\mathrm{Sn}-134 \mathrm{~g}$

$\mathrm{Si}-134 \mathrm{~g}$

$\mathrm{Sb}-1 \overline{3} \mathrm{jg}$

$\mathrm{Sb}-136 \mathrm{~g}$

$\mathrm{Te}-136 \mathrm{~g}$

0.65

0.02

0.01

0.02

0.02

0.03

0.50

0.02

2.86

0.21

$\mathrm{Te}-\mathrm{3} 3 \mathrm{~g}$

0.52

$I-137 \mathrm{~g}$

1.58

Te-138g 1.22

$I-138 \mathrm{~g}$

$\mathrm{Te}-139 \mathrm{~g}$

$\mathrm{I}-139 \mathrm{~g}$

$\mathrm{Te}-140 \mathrm{~g}$

$\mathrm{I}-140 \mathrm{~g}$

$\begin{array}{rrrr}\mathrm{Ga}-81 \mathrm{~g} & 0.02 & \mathrm{As}-85 \mathrm{~g} & 0.10 \\ \mathrm{Ge}-84 \mathrm{~g} & 0.08 & \mathrm{Se}-87 \mathrm{~g} & 0.19 \\ \mathrm{As}-85 \mathrm{~g} & 14.60 & \mathrm{Br}-87 \mathrm{~g} & 11.29 \\ \mathrm{As}-86 \mathrm{~g} & 0.02 & \mathrm{Br}-88 \mathrm{~g} & 34.84 \\ \mathrm{Se}-87 \mathrm{~g} & 0.36 & \mathrm{Br}-89 \mathrm{~g} & 6.65 \\ \mathrm{Br}-87 \mathrm{~g} & 1.83 & \mathrm{Br}-90 \mathrm{~g} & 0.01 \\ \mathrm{Se}-88 \mathrm{~g} & \mathrm{C} .15 & \mathrm{Rb}-92 \mathrm{~g} & 0.01 \\ \mathrm{Br}-88 \mathrm{~g} & 13.15 & \mathrm{Rb}-93 \mathrm{~g} & 2.14 \\ \mathrm{Br}-89 \mathrm{~g} & 25.19 & \mathrm{Rb}-94 \mathrm{~g} & 0.31 \\ \mathrm{Br}-90 \mathrm{~g} & 5.23 & \mathrm{Rh}-115 \mathrm{~g} & 0.02 \\ \mathrm{Kr}-92 \mathrm{~g} & 0.02 & \mathrm{Sb}-134 \mathrm{~g} & 0.10 \\ \mathrm{Rb}-92 \mathrm{~g} & 0.04 & \mathrm{Te}-136 \mathrm{~g} & 3.98 \\ \mathrm{Kr}-93 \mathrm{~g} & 0.14 & \mathrm{Te}-137 \mathrm{~g} & 0.21 \\ \mathrm{Rb}-93 \mathrm{~g} & 3.62 & \mathrm{I}-137 \mathrm{~g} & 32.88 \\ \mathrm{Rb}-94 \mathrm{~g} & 7.50 & \mathrm{I}-138 \mathrm{~g} & 6.81 \\ \mathrm{Y}-97 \mathrm{~g} & 0.07 & \mathrm{I}-139 \mathrm{~g} & 0.07 \\ \mathrm{Y}-98 \mathrm{~g} & 0.02 & \mathrm{Cs}-141 \mathrm{~g} & 0.33 \\ \mathrm{Y}-98 \mathrm{~m} & 0.02 & \mathrm{La}-146 \mathrm{~g} & 0.01 \\ \mathrm{Y}-99 \mathrm{~g} & 0.17 & \mathrm{La}-147 \mathrm{~g} & 0.02\end{array}$

$\mathrm{Nb}-105 \mathrm{~g} \quad 0.01$

$\mathrm{Rh}-115 \mathrm{~g} \quad 0.01$

$\mathrm{Sn}-134 \mathrm{~g} \quad 0.06$

$\mathrm{Sb}-134 \mathrm{~g} \quad 0.06$

$\mathrm{sb}-135 \mathrm{~g} \quad 1.31$

$\mathrm{Te}-136 \mathrm{~g} \quad 1.32$

$\mathrm{Te}-137 \mathrm{~g} \quad 1.80$

$\mathrm{I}-137 \mathrm{~g} \quad 8.52$

$\mathrm{Te}-138 \mathrm{~g} \quad 0.43$

$I-138 \mathrm{~g} \quad 9.09$

I-133g 3.96

$\begin{array}{lll}I-140 \mathrm{~g} & 0.03\end{array}$

$\mathrm{Xe}-14 \mathrm{lg} \quad 0.01$

$\mathrm{Cs}^{-141 \mathrm{~g}} \quad 0.0 \mathrm{~g}$

$\mathrm{Xe}-142 \mathrm{~g} \quad 0.02$

$\begin{array}{cc}C s-142 \mathrm{~g} & 0.08\end{array}$

Cs-143g 0.68

$\mathrm{Xe}-144 \mathrm{~g} \quad 0.01$

Cs-144g 0.09

$\begin{array}{ll}\mathrm{La}-147 \mathrm{~g} & 0.04\end{array}$

$\mathrm{La}-148 \mathrm{~g} \quad 0.01$

La-149g $\quad 0.05$
$(30.05)$

Nuclide

$\begin{array}{rr}\mathrm{As}-85 \mathrm{~g} & 0.10 \\ \mathrm{Se}-87 \mathrm{~g} & 0.19 \\ \mathrm{Br}-87 \mathrm{~g} & 11.29 \\ \mathrm{Br}-88 \mathrm{~g} & 34.84 \\ \mathrm{Br}-89 \mathrm{~g} & 6.65 \\ \mathrm{Br}-90 \mathrm{~g} & 0.01 \\ \mathrm{Rb}-92 \mathrm{~g} & 0.01 \\ \mathrm{Rb}-93 \mathrm{~g} & 2.14 \\ \mathrm{Rb}-94 \mathrm{~g} & 0.31 \\ \mathrm{Rh}-115 \mathrm{~g} & 0.02 \\ \mathrm{Sb}-134 \mathrm{~g} & 0.10 \\ \mathrm{Te}-136 \mathrm{~g} & 3.98 \\ \mathrm{Te}-137 \mathrm{~g} & 0.21 \\ \mathrm{I}-137 \mathrm{~g} & 32.88 \\ \mathrm{I}-138 \mathrm{~g} & 6.81 \\ \mathrm{I}-139 \mathrm{~g} & 0.07 \\ \mathrm{Cs}-141 \mathrm{~g} & 0.33 \\ \mathrm{La}-146 \mathrm{~g} & 0.01 \\ \mathrm{La}-147 \mathrm{~g} & 0.02\end{array}$

Continued 
Table B-VII (Cont.)

$$
(0.0 s)
$$

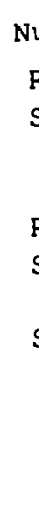
(5.0s)
$(10.0 s)$
$(30.0 s)$

Nuclide $\frac{f}{6}$ Nuclide 8 Nuclide $\frac{\circ}{2}$

I-141g 0.02

$\mathrm{Xe}-14 \mathrm{lg} \quad 0.04$

Cs-14lg 0.03

$\mathrm{Xe}-142 \mathrm{~g} \quad 0.14$

Cs-142g 0.15

$\mathrm{Xe}-143 \mathrm{~g} \quad 0.10$

Cs $-143 \mathrm{~g} \quad 1.50$

$\mathrm{Xe}-144 \mathrm{~g} \quad 0.10$

Cs-144g 0.68

Cs $-145 \mathrm{~g} \quad 0.14$

La $-147 \mathrm{~g} \quad 0.02$

La-148g 0.02

$\mathrm{La}-149 \mathrm{~g} \quad 0.07$

Ag-125g 0.01

In $-129 \mathrm{~g} \quad 0.03$

In-130g 0.02

In-130m 0.03

Cd-131g 0.01

In-131g 0.07

$\begin{array}{ll}\text { In-131m } & 0.16 \\ \text { In-132g } & 0.33\end{array}$

In-133g 0.37

Sn-133g 0.03

In-134g 0.04

Sn-134g 1.11

Sn-135g 0.11

Sb-135g 1.47

$\mathrm{Sb}-136 \mathrm{~g} \quad 1.11$

Te-136g 0.05

$\mathrm{Sb}-137 \mathrm{~g} \quad 0.28$

Te-137g 0.33

$\mathrm{I}-137 \mathrm{~g} \quad 0.17$
$\mathrm{~S}$

$\begin{array}{ll}\mathrm{sb}-138 \mathrm{~g} & 0.11\end{array}$

Te-138g 0.84

$\begin{array}{lll}I-138 \mathrm{~g} & 0.48\end{array}$

$\mathrm{Sb}-139 \mathrm{~g} \quad 0.01$

$\mathrm{Te}-139 \mathrm{~g} \quad 0.50$

$\mathrm{I}-139 \mathrm{~g} \quad 1.69$

$\mathrm{Te}-140 \mathrm{~g} \quad 0.10$

1. 58

$\mathrm{Te}-141 \mathrm{~g} \quad 0.07$

$I-141 \mathrm{~g} \quad 2.27$

$\mathrm{Xe}-141 \mathrm{~g} \quad 0.02$

$I-142 \mathrm{~g} \quad 0.50$

$\mathrm{Xe}-142 \mathrm{~g} \quad 0.18$

$\mathrm{Cs}-142 \mathrm{~g} \quad 0.03$

I-143g 0.20

$\mathrm{sb}-136 \mathrm{~g} \quad 1.32$

Te-136g 0.13

$\mathrm{Sb}-137 \mathrm{~g} \quad 0.18$

Te-137g 0.76

$\begin{array}{lll}I-137 \mathrm{~g} & 0.53\end{array}$

$\mathrm{Te}-138 \mathrm{~g} \quad 1.51$

$I-138 \mathrm{~g} \quad 1.34$

Te-139g 0.41

$\mathrm{I}-139 \mathrm{~g} \quad 3.71$

Te-140g 0.12

I $140 \mathrm{~g} \quad 2.00$

$\mathrm{Te}-141 \mathrm{~g} \quad 0.01$

$\mathrm{I}-141 \mathrm{~g} \quad 1.46$

$\mathrm{Xe}-14 \mathrm{gg} \quad 0.04$

$I-142 \mathrm{~g} \quad 0.04$

$\mathrm{Xe}-142 \mathrm{~g} \quad 0.29$

$\mathrm{Cs}-142 \mathrm{~g} \quad 0.0 \mathrm{~g}$

$I-143 \mathrm{~g} \quad 0.10$

Xe-143g 0.38

$\mathrm{Cs}-143 \mathrm{~g} \quad 1.36$

$\mathrm{Xe}-144 \mathrm{~g} \quad 0.28$

$\mathrm{Cs}-144 \mathrm{~g} \quad 1.76$

$\mathrm{Xe}-145 \mathrm{~g} \quad 0.03$

Cs-145g 2.59

Cs $-146 \mathrm{~g} \quad 0.36$

$\mathrm{Cs}-147 \mathrm{~g} \quad 0.08$

Ia-148g 0.03

La-149g 0.05

La-151g 0.02

Continued 
Table B-VIII (Cont.)
$(0.05)$
$(1.05)$
$(5.0 s)$
$(10.05)$
$(30.0 s)$

$\begin{array}{ll}\text { Nuclide } & \text { g } \\ & \\ \mathrm{Xe}-143 \mathrm{~g} & 0.28 \\ \mathrm{Cs}-143 \mathrm{~g} & 0.60 \\ \mathrm{Xe}-144 \mathrm{~g} & 0.19 \\ \mathrm{Cs}-144 \mathrm{~g} & 1.19 \\ \mathrm{Xe}-145 \mathrm{~g} & 0.03 \\ \mathrm{Cs}-145 \mathrm{~g} & 2.96 \\ \mathrm{Cs}-146 \mathrm{~g} & 0.97 \\ \mathrm{Cs}-147 \mathrm{~g} & 0.10 \\ \mathrm{Cs}-148 \mathrm{~g} & 0.02 \\ \mathrm{La}-148 \mathrm{~g} & 0.02 \\ \mathrm{La}-149 \mathrm{~g} & 0.02 \\ \mathrm{La}-151 \mathrm{~g} & 0.02\end{array}$

TABLE B-IX

232Th FISSION PULSE

PER CENT CONTRIBUTION PER PRECURSOR GREATER THAN $0.01 \%$ FOR ENERGIES ABOVE $4.0 \mathrm{MeV}$

$$
(0.0 s)
$$

\begin{tabular}{ll} 
Nuclide & \multicolumn{1}{l}{} \\
Ga- $83 g$ & 0.09 \\
Ga- $84 \mathrm{~g}$ & 0.04 \\
Ga- $85 \mathrm{~g}$ & 0.01 \\
$\mathrm{Ge}-85 \mathrm{~g}$ & 0.06 \\
$\mathrm{Ag}-96 \mathrm{~g}$ & 0.04 \\
$\mathrm{As}-87 \mathrm{~g}$ & 0.58 \\
$\mathrm{As}-88 \mathrm{~g}$ & 0.07 \\
$\mathrm{As}-89 \mathrm{~g}$ & 0.03 \\
$\mathrm{Se}-89 \mathrm{~g}$ & 0.03 \\
$\mathrm{Se}-91 \mathrm{~g}$ & 0.02 \\
$\mathrm{Br}-91 \mathrm{~g}$ & 5.52 \\
$\mathrm{Br}-92 \mathrm{~g}$ & 89.71 \\
$\mathrm{Br}-93 \mathrm{~g}$ & 0.07 \\
$\mathrm{Br}-94 \mathrm{~g}$ & 0.01 \\
$\mathrm{Rb}-95 \mathrm{~g}$ & 0.53 \\
$\mathrm{Rb}-96 \mathrm{~g}$ & 0.90 \\
$\mathrm{Rb}-97 \mathrm{~g}$ & 1.09 \\
$\mathrm{Rb}-98 \mathrm{~g}$ & 0.71 \\
$\mathrm{I}-140 \mathrm{~g}$ & 0.01 \\
$\mathrm{I}-141 \mathrm{~g}$ & 0.40
\end{tabular}
$(1.05)$

( 5.05$)$

Nuclide

Ga- 83g 0.06

Ge- $85 \mathrm{~g} \quad 0.02$

As- $85 \mathrm{~g} \quad 0.03$

As- $86 \mathrm{~g} \quad 0.14$

Ass- $87 \mathrm{~g} \quad 0.38$

Se- $89 \mathrm{~g} \quad 0.04$

Se- $90 \mathrm{~g} \quad 0.01$

$\mathrm{Br}-90 \mathrm{~g} \quad 0.02$

$\mathrm{Br}-91 \mathrm{~g} 11.57$

$\mathrm{Br}-92 \mathrm{~g} 86.06$

Rb- $95 \mathrm{~g} \quad 0.62$

Rb- $96 \mathrm{~g} \quad 0.22$

$\mathrm{Rb}-97 \mathrm{~g} \quad 0.12$

I-140g 0.03

$I-141 \mathrm{~g} \quad 0.61$ \begin{tabular}{lr} 
Nuclide & \multicolumn{2}{l}{} \\
Ga- 82g & 0.05 \\
As- 85g & 4.54 \\
As- 86g & 3.58 \\
As- 87g & 0.02 \\
Se- 89g & 0.02 \\
Se- 90g & 0.01 \\
Br- $90 \mathrm{~g}$ & 2.92 \\
Br- $91 \mathrm{~g}$ & 63.60 \\
$\mathrm{Br}-92 \mathrm{~g}$ & 21.58 \\
$\mathrm{Kr}-95 \mathrm{~g}$ & 0.03 \\
$\mathrm{Rb}-95 \mathrm{~g}$ & 1.96 \\
$\mathrm{I}-140 \mathrm{~g}$ & 0.82 \\
$\mathrm{I}-141 \mathrm{~g}$ & 0.83 \\
$\mathrm{Cs}-147 \mathrm{~g}$ & 0.02
\end{tabular}

$(10.0 \mathrm{~s})$

$(30.05)$

Nuclide Nuclide 8

Ga- $82 \mathrm{~g} \quad 0.01$

As- $85 \mathrm{~g} 82.24$

As- $85 \mathrm{~g} 52.71$

As- $86 \mathrm{~g} \quad 4.86$

$\mathrm{Br}-90 \mathrm{~g} 27.25$

$\mathrm{Br}-91 \mathrm{~g} 12.61$

$\mathrm{Br}-92 \mathrm{~g} \quad 0.09$

Kr- $95 \mathrm{~g} \quad 0.02$

$\mathrm{Rb}-95 \mathrm{~g} \quad 1.33$

$\mathrm{I}-140 \mathrm{~g} \quad 1.08$

$I-141 \mathrm{~g} \quad 0.03$ 